\title{
NASCENTES, VEREDAS E ÁREAS ÚMIDAS \\ Revisão Conceitual e Metodologia de Caracterização e Determinação: Estudo de Caso na Estação Ecológica de Águas Emendadas - Distrito Federal
}

Área de concentração: Hidrogeologia e Meio Ambiente

MARINA LIMA QUEIROZ

Orientador: José Eloi Guimarães Campos 


\section{NASCENTES, VEREDAS E ÁREAS ÚMIDAS \\ Revisão Conceitual e Metodologia de Caracterização e Determinação: Estudo de Caso na Estação Ecológica de Águas Emendadas - Distrito Federal}

Dissertação de mestrado apresentada ao Programa de Pós-Graduação em Geociências Aplicadas, da Universidade de Brasília, como parte dos requisitos para a obtenção do título de Mestre em Hidrogeologia.

Área de concentração: Hidrogeologia e Meio Ambiente

ORIENTADOR: José Eloi Guimarães Campos

Brasília 


\section{NASCENTES, VEREDAS E ÁREAS ÚMIDAS \\ Revisão Conceitual e Metodologia de Caracterização e Determinação em Estudo de Caso na Estação Ecológica de Águas Emendadas - Distrito Federal}

Esta dissertação foi julgada adequada para a obtenção do título de Mestre em Geociências Aplicadas e aprovada em sua forma final pelo Orientador e pela Banca Examinadora.

\section{Banca Examinadora:}

Prof. Dr. José Eloi Guimarães Campos (UnB)

Prof. Dr. Ricardo Galeno Fraga de Araujo Pereira (Membro Externo - UFBA)

Prof. Dr. Detlef Hans Gert Walde (Membro Interno - UnB)

Brasília, dezembro de 2015. 


\section{DEDICATÓRIA}

Dedico este trabalho àqueles com quem caminho pelas veredas da vida:

Meus pais, Nelson e Ceiça, que me ensinam diariamente a ciência do bem-viver, com seu amor e serviço,

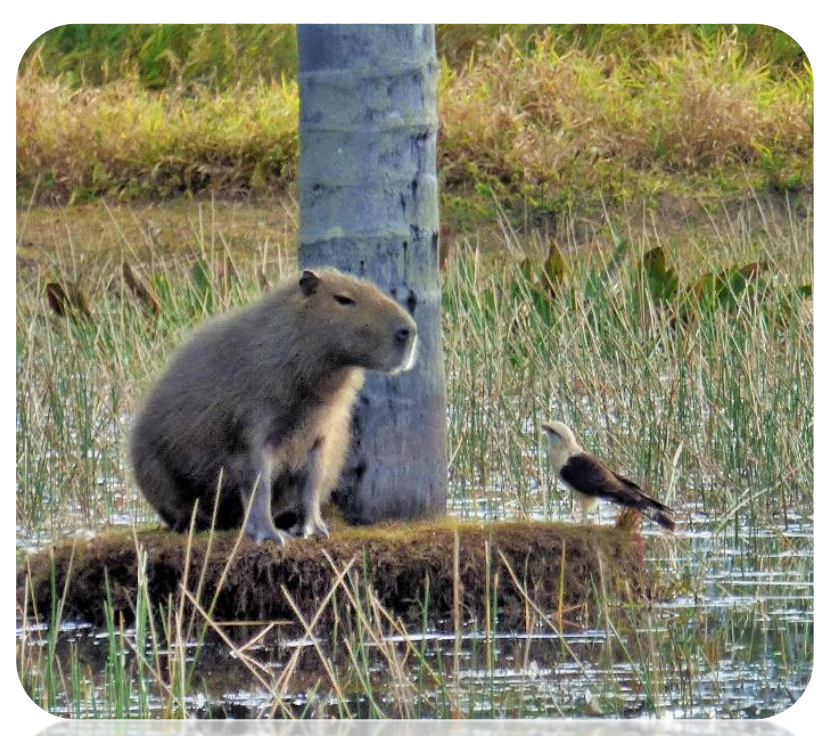

Meu irmão Eduardo, por sua criatividade e apurado senso crítico;

Meu Mar, Martin. Nós nos completamos.

Kelma, flor do cerrado, amiga-presente.

Familiares, amigos e demais apoiadores, que tornam a jornada mais leve, doce e divertida;

Professores e mestres, pela orientação e partilha do conhecimento

Deus, fonte de inspiração, sabedoria e propósito. 


\section{AGRADECIMENTOS}

Ao Programa de Pós-Graduação em Geociências Aplicadas, PPGGIG, pela oportunidade de realização de trabalhos em minha área de pesquisa e ao Prof. Dr. José Eloi Guimarães Campos, pelo total apoio, dedicação, disponibilidade e eficiência demonstrados nas disciplinas ministradas, orientações, revisões e saídas de campo. À equipe da Secretaria de Pós-Graduação do IG pelo importante auxílio para a concretização do trabalho, especialmente Alice Maria Falquetto e Harianna Gonçalves Lacerda.

À turma de graduação de Hidrogeologia do $1^{\circ}$ semestre de 2015 pelo auxílio na coleta de dados nos limites da Estação Ecológica de Águas Emendadas e a Gustavo Vasconcelos Costa Lacerda pela motivação em acompanhar algumas das campanhas de levantamento realizadas. Aos professores Weliton Borges, Geraldo Boaventura, Roberta Vidotti, Luciano Soares da Cunha e Henrique Llacer Roig e aos colegas de todas as disciplinas da pós-graduação que acrescentaram ao crescimento científico.

À chefia e aos colegas do MPF pelo apoio à realização do mestrado, com ênfase ao Subprocurador-Geral da República Mário Geisi e à Subprocuradora-Geral da República Sandra Cureau, coordenadores da $4^{a}$ Câmara de Coordenação do Ministério Público, respectivamente no período correspondente ao início e ao final desta dissertação, pela autorização à utilização de dados da $4^{\mathrm{a}} \mathrm{CCR}$ e pela compreensão e visão de vanguarda quanto à qualificação da equipe, demonstradas ao conceder o afastamento para a conclusão desta dissertação de mestrado pelo período de dois meses. À Secretária Executiva da $4^{\mathrm{a}} \mathrm{CCR}$ Denise Christine Nicholaids e ao Assessor Pericial Chefe Marco Antônio Bichara pela articulação, logística, mediação e suporte em relação à conciliação do trabalho pericial com os estudos acadêmicos. Aos setores de Gestão de Pessoas e à Secretária Geral da Procuradoria Geral da República pela celeridade no processo de autorização de afastamento. À equipe de trabalho da qual faço parte, pelas trocas de ideias, incentivo, compreensão e companheirismo. A Amy Vasconcelos de Souza, Valdir Carlos da Silva Filho, Adriana Oliva, Juliana Sarkis Costa, Luciana Adele Maria Bucci e Aurélio Rodrigues de Loiola Junior, pelo efetivo apoio. A Humberto Alcântara Ferreira Lima e Cristina de Queiroz Telles Mafra, minhas referências no desenvolvimento do trabalho geológico dedicado, ponderado e efetivo.

Aos amigos Carlos Alberto Correia, Bruno Carramshi Borges, servidores do Ministério Público Federal, e Giancarlo Brugnara Chelotti, servidor do Instituto Brasília Ambiental - Ibram, pelas contribuições relevantes a este trabalho, em campo e em escritório, e pelos projetos de publicação ainda relacionados ao tema. Aos servidores do Ibram Paulo César Magalhães Fonseca, Danielle Vieira Lopes, Renata Machado Mongin, Marina Lopes Ribeiro, Renata Almeida Motta, Eriel Sinval Cardoso, Pedro Braga Netto, Edna, Jeovane Lúcio de Oliveira, Alípio Pires 
Quintanilha, Igor Proença do Espírito Santo e Misael da Silva Gomes que incentivaram e auxiliaram a realização da pesquisa na ESEC-AE e ao servidor da ADASA Dennis Monteiro de Barros que acompanhou a primeira saída de campo. Ao servidor da Terracap Vitor Hugo Santos da Silva pelo auxílio na disponibilização das imagens e fotografias aéreas de Águas Emendadas e arredores.

Àqueles, além dos supracitados, com quem também tive a oportunidade de desenvolver a reflexão e os conhecimentos sobre nascentes e áreas úmidas em viagens e vistorias, entre os quais Sandra Nami Amenomori (fonte termal); Alessandro Filgueiras da Silva (várzea); Ruth Rodrigues Tabaczenski (Pantanal e várzea); Clauber Pacheco (Pantanal); Nathaly Campos Feitosa (Pantanal); Tulio Favaro Beggiato (Pantanal); Alan dos Santos Brasil (várzea); Luciana Sampaio (solo com elevado grau de hidromorfismo); Marcelo Volsi (várzea) e Ana Paula Gonçalves de Lima (nascente cárstica).

À Laís Farias Oliveira Lima pela motivação e pelo empréstimo de material do acervo pessoal acerca de Águas Emendadas. A Vitor Silva Paiva do Laboratório de Sistema de Informações Espaciais - LSIE da Universidade de Brasília pelo apoio na elaboração dos mapas. À Hevelyn Peralta Leão, Henrique Meuren e Guilherme Neiva Rodrigues Oliveira pelo traçado profissional das figuras relativas aos cenários espaço-temporais e aos modelos conceituais desenvolvidos como produto desta dissertação. A meus pais e irmão pela estruturação de toda a logística, torcida, conselhos, orações e envolvimento afetivo com Águas Emendadas. A Martin Badham pelas traduções, companheirismo, aprofundamento nas pesquisas confiáveis sobre o tema, papos atenciosos, acolhida dos sonhos e das epifanias e incentivo nas realizações.

Nesta dissertação o fluxo de trabalho é originário de muitas fontes de inspiração e veredas caminhadas em equipe. 


\section{RESUMO}

Esta dissertação propõe uma reflexão acerca de termos controversos, sob o ponto de vista técnico e legal, relativos a nascentes, veredas e áreas úmidas. As controvérsias conceituais destas feições hidrológicas têm importantes implicações jurídicas. Conforme a Lei 12.651/2012 (Brasil 2012), as áreas de faixas marginais e entorno desses bens naturais são passíveis de proteção a partir das Áreas de Preservação Permanente - APP. Nelas, o regime de proteção é diferenciado, com manutenção ou recomposição da vegetação local. A intervenção nestas áreas ou a supressão de vegetação nativa em APP somente é possível em hipóteses excepcionais previstas na legislação. Além da legislação florestal, o Brasil possui um arcabouço legal ambiental com diferentes enfoques quanto aos instrumentos de proteção, que visam restringir os impactos em corpos hídricos e orientar o uso racional desses recursos, pelas múltiplas funções ambientais desempenhadas. Porém, é necessário potencializar a aplicação das normas e aperfeiçoar a integração das políticas nacionais entre si e com tratados internacionais, como a Convenção de Ramsar. Em função das limitações impostas, questões de ocupação humana e uso alternativo do solo ficam vinculadas à adequada conceituação, determinação e caracterização dessas feições. Este trabalho busca contribuir com a revisão dos conceitos, além de propor metodologia para a caracterização e determinação de nascentes, veredas e áreas úmidas, com base em estudo de caso na Estação Ecológica de Águas Emendadas - ESEC-AE, no Distrito Federal. Esta se insere em uma configuração hidrológica de grande relevância em termos de feições hídricas, em interface entre o sistema hidrogeológico (Província Hidrogeológica Escudo Central) e a rede hidrológica superficial (Bacia do Tocantins e Bacia do Paraná). Os atributos hídricos, ecológicos e funções ambientais fazem da Unidade de Conservação de Proteção Integral local com potencial para reconhecimento como Sítio Ramsar, constituído por áreas úmidas das classes de veredas e de solos com elevado grau de hidromorfismo. Contudo, há indícios de que as áreas úmidas vêm apresentando redução dimensional na ESEC-AE, o que requer estudos complementares quanto aos fatores que influenciam esse fenômeno e quanto às medidas de mitigação/recuperação. $\mathrm{O}$ fato chama atenção dado que o fenômeno das águas que se emendam, ou seja, o sistema hídrico de Águas Emendadas, constitui a essência e a identidade da Unidade de Conservação.

Palavras-chaves: Nascentes, Veredas, Áreas Úmidas, Solos hidromórficos, Águas Emendadas, Sítio Ramsar. 


\begin{abstract}
This dissertation proposes that the current legal definition of springs, veredas and wetlands should be revised. The existing concepts applied to these hydrological systems are controversial, but at the same time have important legal implications. According to Law 12.651/2012 (Brazil 2012), marginal zones, as well as their surroundings, are entitled to protection as 'Areas of Permanent Preservation' - APP. Being defined as an APP area allows a differentiated protection regime, such as maintenance or restoration of the local vegetation. Intervention in APP areas, or the suppression of the local vegetation, is only possible in exceptional circumstances determined by the law. However, current legislation is inadequate. Brazil's environmental legal framework has many different approaches and many different instruments, all of which aim to restrict the impacts on bodies of water and guide the reasonable use of these vital resources. However, there needs to be improvement in the application of these legal standards, better integration between national laws, and improved interaction between Brazil's national laws and international treaties, such as the Ramsar Convention. Springs, veredas and wetlands need to be better conceptualized in the law, which would help to inform decisions on human settlement and alternative land use. This paper proposes a revision of the concepts for springs, veredas and wetlands, as well as a methodology for their future definition, based on a case study of the Ecological Monitoring Station in Águas Emendadas (ESEC-AE) in Brazil's Federal District. ESEC-AE is particularly relevant for this study, given its role as a meeting point between the Escudo Central hydrogeological system and the Tocantins and Paraná Basins surface hydrology network. ESEC-AE's hydrological and ecological attributes, combined with its environmental functions, indicate its potential to be recognized as a Ramsar Site. Nevertheless, there are indications that the ESEC-AE wetlands are reducing in size. Further studies are required to determine the factors influencing the shrinkage and any possible mitigation / recovery measures. The reduction in the ESEC-AE wetlands is particularly concerning, given their hydrological importance.
\end{abstract}

Key words: Springs, Wetlands, Veredas, Hydromorphic Soils, Águas Emendadas, Ramsar Site. 


\section{SUMÁRIO}

\section{Sumário}

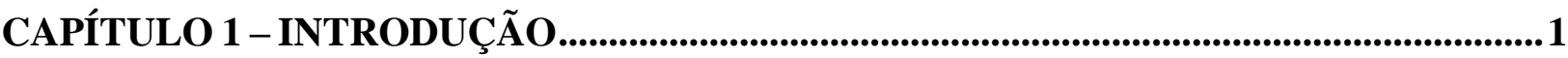

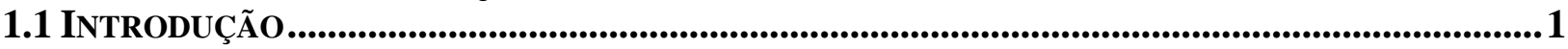

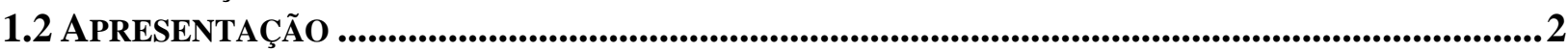

1.3 PROBLEMAS NOS CONCEITOS DE NASCENTES, VEREDAS E ÁREAS ÚMIDAS ...........................3

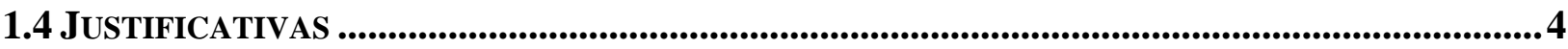

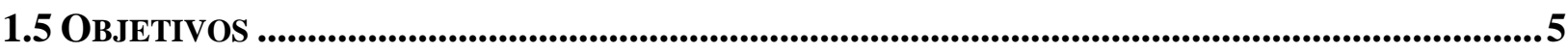

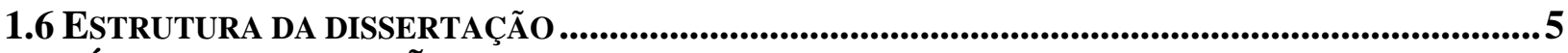

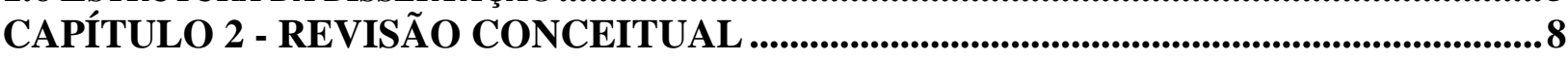

2.1 DEFINIÇÕES INFORMAIS: SENSO COMUM, REGIONALISMOS E CORRESPONDÊNCIA DOS

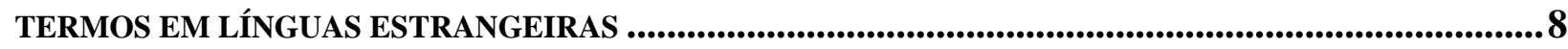

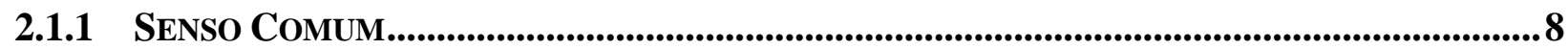

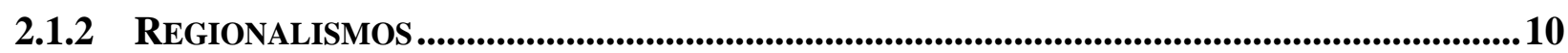

2.1.3 CORRESPONDÊNCIAS DOS TERMOS EM LÍNGUAS ESTRANGEIRAS................................11

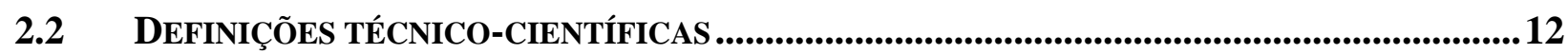

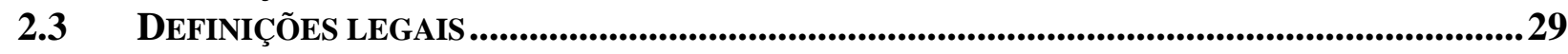

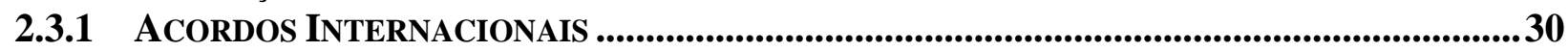

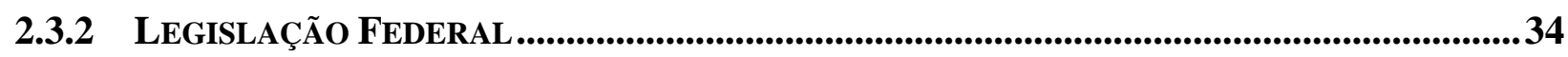

2.4 APLICAÇÃO DOS CONCEITOS DE NASCENTES, VEREDAS E ÁREAS ÚMIDAS CONFORME A LEI 37

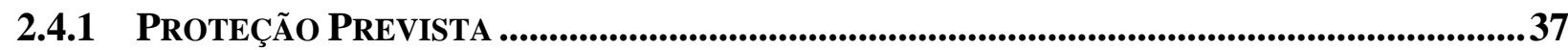

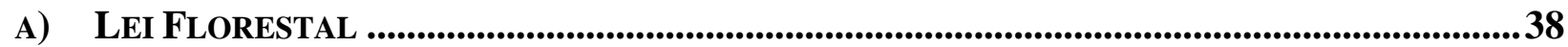

B) Política NACIONAL do Meio AMBIENTE.........................................................................44

C) Plano Estratégico Nacional de Áreas Protegidas......................................................45

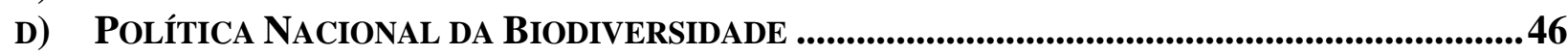

E) Política Nacional de Gerenciamento CoSTEIRo .......................................................... 47

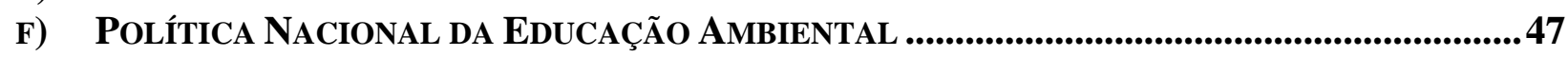

G) Política NACIONAL dos RECURSOS HídRICOS................................................................ 48

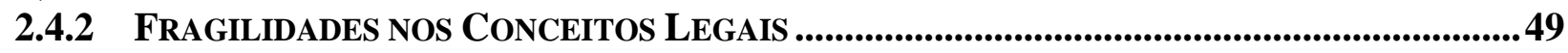

2.4.3 Casos InVESTIGAdos Pelo Ministério PÚBlico Federal ........................................51

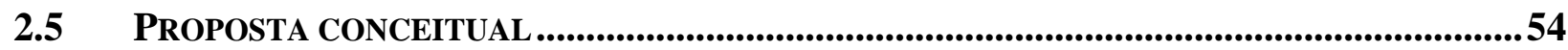

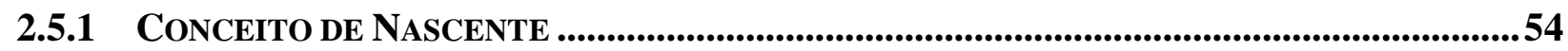

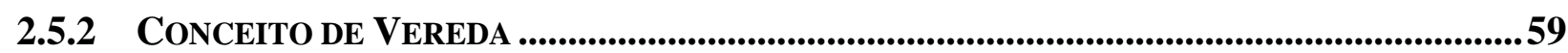

2.5.3 CONCEITO DE ÁREAS ÚMIDAS ....................................................................................60

CAPÍTULO 3 - PROPOSTA METODOLÓGICA ...................................................................... 63

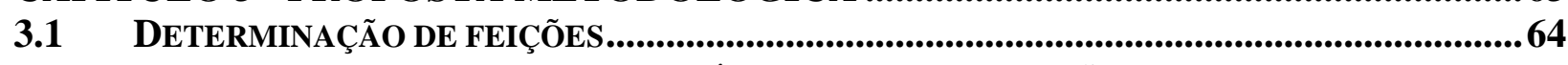

3.1.1 LEVANTAMENTOS ESPACIAIS: CRITÉRIOS DE IDENTIFICAÇÃO E ESCALA .....................65

3.1.2 LEVANTAMENTOS TEMPORAIS: EFEMERIDADE, SAZONALIDADE OU PERENIDADE DE

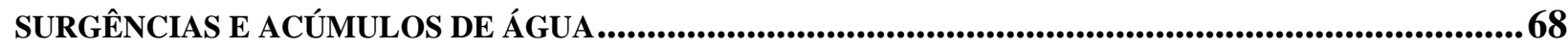

3.1.3 PRODUTO: CENÁRIOS ESPAÇO-TEMPORAIS...............................................................71

3.2 CARACTERIZAÇÃO DAS FEIÇÕES ....................................................................................... 71

3.2.1 DESCRIÇÃO DAS FEIÇÕES QUANTO AOS CRITÉRIOS TIPIFICADORES POR MEIO DE

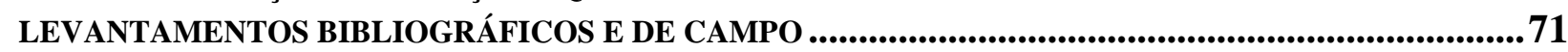

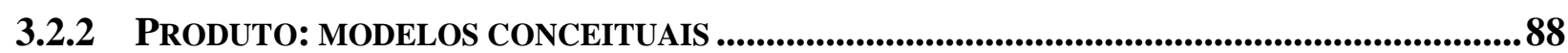

CAPÍTULO 4 - ESTUDO DE CASO: ESTAÇÃO ECOLÓGICA DE ÁGUAS

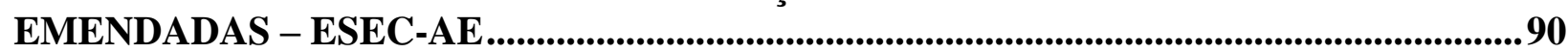

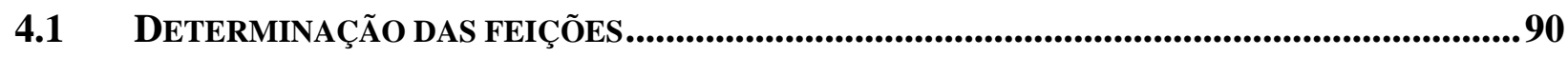

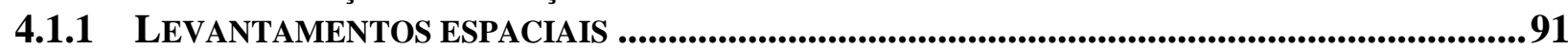

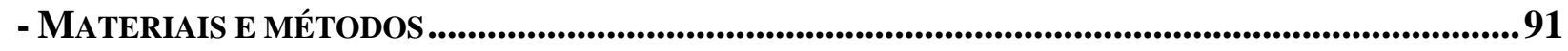




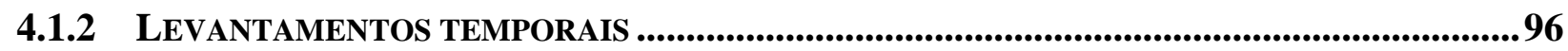

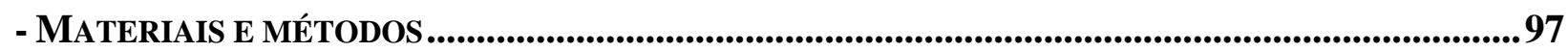

4.1.3 PRODUTO: CENÁRIOS ESPAÇO-TEMPORAIS...............................................................100

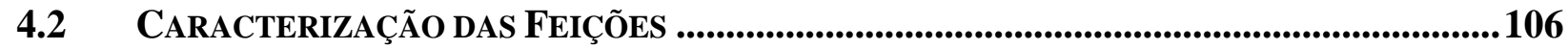

4.2.1 DESCRIÇÃO DAS FEIÇÕES QUANTO AOS CRITÉRIOS TIPIFICADORES POR MEIO DE LEVANTAMENTOS BIBLIOGRÁFICOS E DE CAMPO ..........................................................106

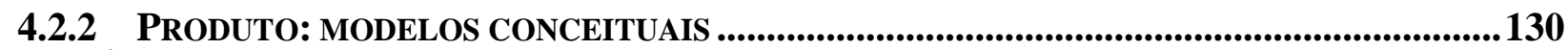

CAPÍTULO 5 - CONSIDERAÇÕES FINAIS ..........................................................................138

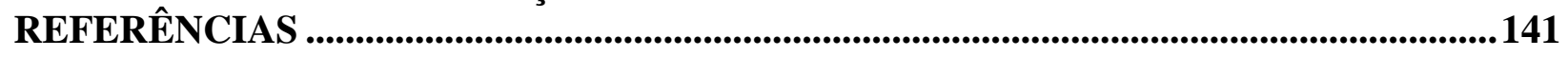




\section{LISTA DE FIGURAS}

Figura 1 - Fluxograma de estrutura da dissertação................................................................ 7

Figura 2 - "Morichales" em Gran Sabana - Venezuela. Buritizal em contexto de savana........... 12

Figura 3 - Contexto de cabeceira. ................................................................................... 13

Figura 4 - Nascentes difusas em contexto de solo hidromórfico............................................. 16

Figura 5 - Nascentes controladas por estruturas rúpteis. Nascentes de fraturas (a) e nascentes de

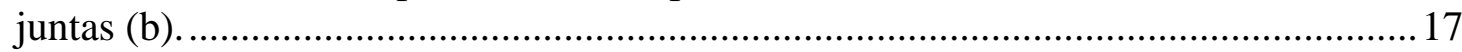

Figura 6 - Nascentes tubulares em sistema cárstico............................................................ 17

Figura 7 - Solo com elevado grau de hidromorfismo em contexto de depósitos coluvionares na Serra do Itatiaia/RJ. Nascente primária não é visível................................................. 18

Figura 8 - Nascente artesiana e termal, Chiang Rai - Tailândia............................................ 18

Figura 9 - Nascentes de depressão .................................................................................... 19

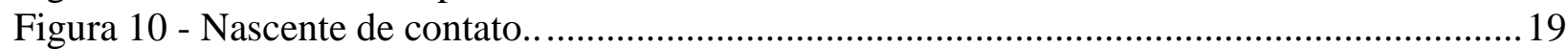

Figura 11 - Nascente de barreira. ..................................................................................... 20

Figura 12 - Nascente intermitente: "Ebbing and Flowing Spring" no estado americano do

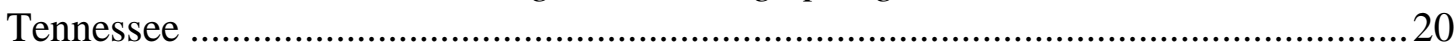

Figura 13 - Paleonascente (a). Depósito de travertino (b) em contexto de nascentes (gêiseres) -

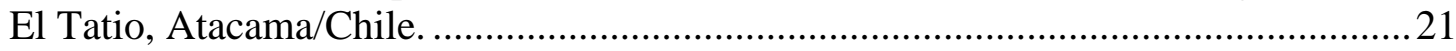

Figura 14 - Nascente submersa no Rio da Prata -- Bonito/MS. ..................................................2 22

Figura 15 - Gêiser em El Tatio - Atacama/Chile...............................................................2 23

Figura 16 - Complexo vegetacional de vereda na ESEC-AE.................................................... 24

Figura 17 - Pantanal Sul-Mato-Grossense. Rio Corumbá............................................................ 25

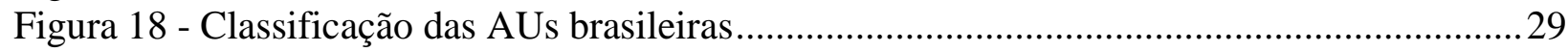

Figura 19 - Modelo conceitual de cabeceira: conjunto de nascentes e olhos d'água que compõe o

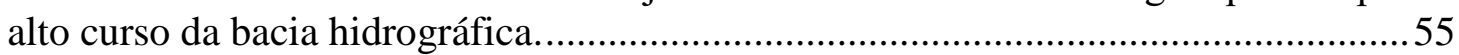

Figura 20 - Descarga de água subterrânea é denominada AU quando o fluxo d'água não pode ser imediatamente observado a partir de olhos d'água (OD). Caso de nascentes (N) difusas/secundárias em contexto de solos com elevado grau de hidromorfismo.........55

Figura 21 - Olho d'água no semiárido, Serra da Joaninha entre Tauá e Independência - Ceará .56

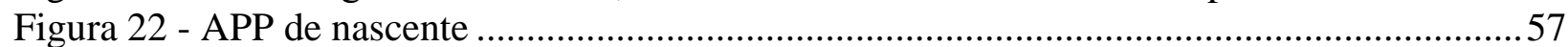

Figura 23 -Vereda típica: área úmida caracterizada por renque de buritis associada à vegetação rasteira. Parque Nacional das Sempre-Vivas, Diamantina/MG ...................................59

Figura 24 - Carnaubal, outra categoria de área úmida tipificada pela fitofisionomia que deve ter

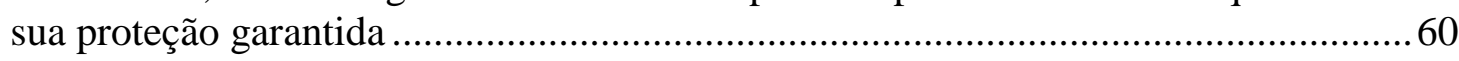

Figura 25 - Modelo conceitual exemplificativo de algumas das categorias de áreas úmidas ......61 61

Figura 26 - Reconhecimento visual de feições hídricas em campo...........................................67

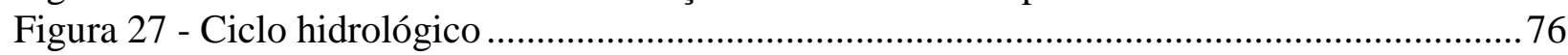

Figura $28-1^{\circ}$ nível categórico do SiBCS - treze ordens de solos e suas características associadas. Entre elas, sete podem apresentar condições de hidromorfismo (realçadas

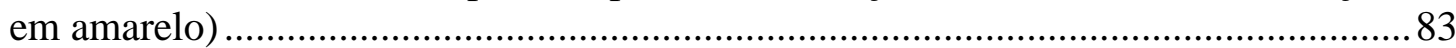

Figura 29 - Gleissolo. Condicionante: solo de textura muito argilosa e pouco estruturado em todo o perfil.

Figura 30 - Neossolo Quartzarênico Hidromórfico. Condicionante: solo de textura arenosa em todo o perfil limitado por substrato rochoso - quartzito silicificado........................... 87

Figura 31 - Neossolo Quartzarênico Hidromórfico. Condicionante: input maior que output....... 88

Figura 32 - Gleissolo. Condicionante: superfície potenciométrica suspensa por camada

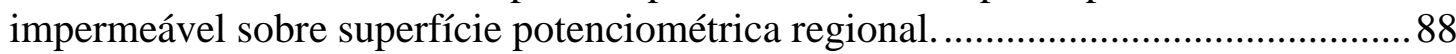

Figura 33 - Mapa de localização da ESEC-AE ................................................................... 92

Figura 34 - Mapa de áreas potencialmente úmidas e pontos de levantamento. ..........................94

Figura 35 - Refinamento do Mapa Pedológico. Pedossequência fundamenta análise espaçotemporal dos processos relativos às feições hídricas na ESEC-AE, com base no critério identificador de elevado grau de hidromorfismo para AUs 98 
Figura 36 - Complexo vegetacional da Vereda Grande, ESEC-AE......................................... 108

Figura 37 - Perfil da ESEC-AE no limite E. ........................................................................... 113

Figura 38 - Perfil da ESEC-AE entre planos intermediários e vale da vereda........................... 114

Figura 39 - Perfil da ESEC-AE de SW para NE. Representação do vale da vereda. Tendência de captura de drenagem.

Figura 40 - Chuva média mensal na Estação Principal da Embrapa Cerrados .......................... 116

Figura 41 - A ESEC-AE insere-se em contexto de duas das maiores regiões hidrográficas brasileiras: Tocantins/Araguaia e Paraná.

Figura 42 - Bacias hidrográficas brasileiras cujas nascentes se localizam na ESEC-AE. Ao Norte da linha amarela situa-se a Bacia do Tocantins/Araguaia. Ao Sul da linha amarela, a Bacia do Paraná .....

Figura 43 - Microbacias hidrográficas da ESEC-AE: As Microbacias dos Córregos Palmeiras, Maranhão e Vereda Grande integram a Bacia do Tocantins. A Microbacia Fumal integra a Bacia do Paraná

Figura 44 - Visão 3D do conjunto de drenagem das Águas Emendadas, destacando as rampas de escoamento superficial de cada drenagem. Contornos ressaltados em vermelho chamam atenção para áreas de captação de água: A. de propriedade particular com pivô central; B. de poço tubular dentro da ESEC-AE; C. da Caesb.

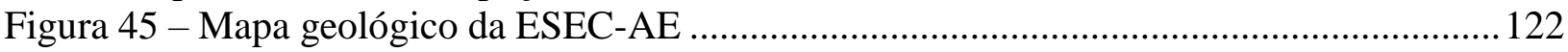

Figura 46 - Coluna estratigráfica do Distrito Federal. ........................................................... 123

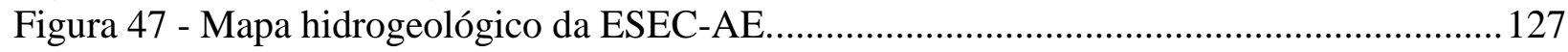

Figura 48 - Mapa de pedoformas da ESEC-AE. ............................................................... 129

Figura 49 - Registro fotográfico de amostras coletadas na ESEC-AE representativas da pedossequência: LV; LVA; LA; PGX; e GX........................................................ 129

Figura 50 - Modelo tridimensional da ESECAE com foco no vale da vereda........................... 130

Figura 51 - Contexto geral da ESEC-AE em modelo tridimensional com exagero vertical....... 131

Figura 52 - Nascente de fratura do Córrego Cascarra ........................................................... 132

Figura 53 - Modelo de nascente, cujo fluxo de água é condicionado pelo plano de fratura......132

Figura 54 - Complexo vegetacional da Vereda Grande. Transição entre fitofisionomias de vereda/buritizal/mata de galeria

Figura 55 - Modelo de nascentes submersas de vereda, cujo fluxo é controlado por plano de falha

Figura 56 - Contexto de cabeceira: área úmida composta por Gleissolo Háplico, com olhos d'água e nascentes difusas

Figura 57 - Modelo de cabeceira. Nascentes e olhos d'água do Córrego Tabatinga. O nível da superfície potenciométrica (SP) se desloca ao longo do ciclo hídrico e determina a surgência em olhos d'água

Figura 58 - Olho d'água determinado por contato geológico ................................................. 135

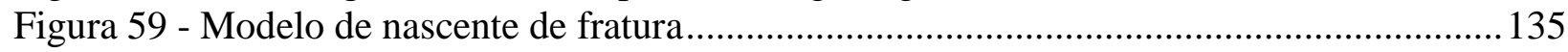

Figura 60 - Murundus. Pequenos morrotes com vegetação arbustiva em meio a campo limpo

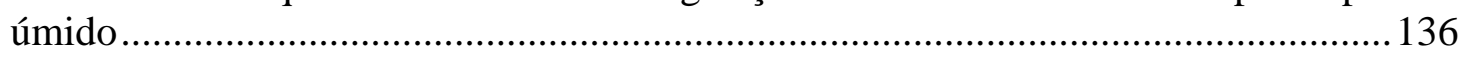

Figura 61 - Modelo de murundus ................................................................................... 136

Figura 62 - Nascente de depressão da Lagoa Bonita............................................................ 137

Figura 63 - Modelos de nascente cárstica e de depressão da Lagoa Bonita............................... 137 


\section{LISTA DE TABELAS}

Tabela 1 - Zonas úmidas brasileiras incluídas na Lista Ramsar.............................................. 32

Tabela 2 - Critérios para a proposição de Sítios Ramsar no território brasileiro. ......................... 34

Tabela 3 - Atividades de Utilidade Pública........................................................................... 41

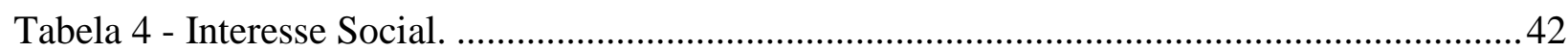

Tabela 5 - Proposta conceitual: nascente, olho d'água, cabeceira e fonte...................................58

Tabela 6 - Levantamentos Espaciais de Feições Hídricas na ESEC-AE .................................... 96

Tabela 7 - Levantamentos Temporais de Feições Hídricas na ESEC-AE. ................................. 99

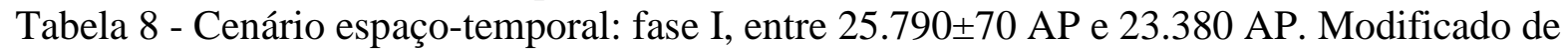

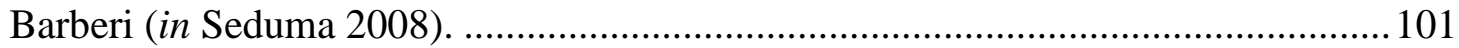

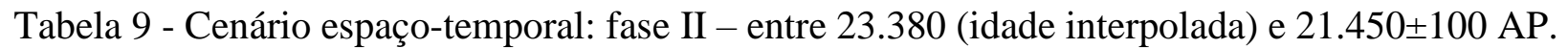

Modificado de Barberi (in Seduma 2008) ................................................................ 102

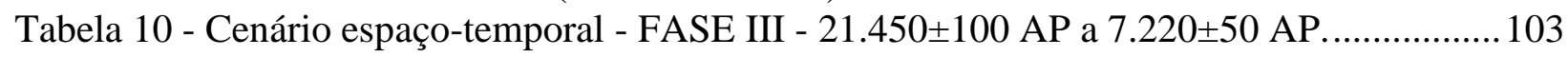

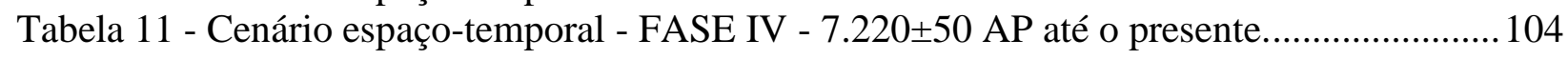

Tabela 12 - Síntese da singularidade do fenômeno de águas emendadas. Fonte (CAMPOS in SEDUMA).

Tabela 13 - Caracterização simplificada dos sistemas do Domínio Intergranular do Distrito Federal. Fonte: Souza \& Campos (2001) apud Moraes \& Campos in Seduma (2008).

Tabela 14 - Síntese da classificação dos sistemas/subsistemas de aquíferos fraturados do DF, com respectivas vazões médias dos poços tubulares profundos. Adaptado de Campos \& Freitas Silva apud Moraes \& Campos in Seduma (2008)....................................... 126

Tabela 15 - Síntese do Modelo Conceitual - Nascente de fratura (1)........................................ 132

Tabela 16 - Síntese do Modelo Conceitual - Vereda Grande(2) ................................................. 133

Tabela 17 - Síntese do Modelo Conceitual - Cabeceira (3)..................................................... 134

Tabela 18 - Síntese do Modelo Conceitual - Olho d'Água de contato (4) ................................ 135

Tabela 19 - Síntese do Modelo Conceitual - Murundus (5) .................................................... 136

Tabela 20 - Síntese do Modelo Conceitual - Lagoa Bonita (6) ............................................... 137 


\section{CAPÍTULO 1 \\ INTRODUÇÃO}

\subsection{INTRODUÇão}

Esta dissertação propõe uma reflexão acerca de termos controversos, sob o ponto de vista técnico e legal, sobre as feições de interface entre o sistema aquífero e sistema superficial referentes a nascentes, veredas e áreas úmidas. As controvérsias conceituais destas feições hidrológicas têm importantes implicações jurídicas. Em função disso, questões sobre ocupação humana ou uso alternativo do solo ficam vinculadas à adequada conceituação, determinação e caracterização dessas feições.

Conforme a Lei 12.651/2012 (Brasil 2012 a) as áreas de faixas marginais e entorno desses bens naturais são passíveis de proteção a partir das Áreas de Preservação Permanente - APP. Nelas, o regime de proteção é diferenciado, com a necessidade de manutenção ou de recomposição da vegetação local. A intervenção nestas áreas ou a supressão de vegetação nativa em APP somente é possível em hipóteses excepcionais previstas na legislação.

Além da legislação florestal, o Brasil possui um arcabouço legal ambiental com diferentes enfoques quanto aos instrumentos de proteção, que visam restringir os impactos em corpos hídricos e orientar o uso racional desses recursos, em razão das múltiplas funções ambientais que estas áreas podem desempenhar. Porém, é necessário potencializar a aplicação das normas e aperfeiçoar a integração das políticas nacionais entre si e com tratados internacionais, como a Convenção de Ramsar.

Um dos órgãos públicos que atuam para garantir o direito difuso ao meio ambiente equilibrado é o Ministério Público. Para embasar inquéritos e ações civis públicas, os procuradores e promotores - respectivamente na esfera federal e estadual - frequentemente consultam a equipe técnica de analistas periciais, quanto aos conceitos técnicos nas definições legais e quanto à determinação de feições a serem protegidas. A temática deste estudo visa aprofundar a discussão dos conceitos de nascentes, veredas e áreas úmidas para o desenvolvimento de suporte técnico e científico adequado.

Além de procurar contribuir com a revisão dos conceitos, este trabalho propõe método para a determinação e caracterização de nascentes, veredas e áreas úmidas e o aplica em estudo de caso na Estação Ecológica de Águas Emendadas - ESEC-AE. Esta se insere em uma configuração hidrológica de grande relevância em termos de feições hídricas, na interface entre o sistema hidrogeológico (Província Hidrogeológica Escudo Central) e a rede hidrológica superficial (bacias do Tocantins e do Paraná). Os atributos hídricos, ecológicos e funções ambientais fazem desta 
Unidade de Conservação de Proteção Integral um local com potencial para reconhecimento como Sítio Ramsar. Contudo, há indícios de que as áreas úmidas vêm diminuindo na ESEC-AE, o que requer estudos quanto aos fatores que influenciam esse fenômeno e quanto às medidas de mitigação/recuperação.

A unidade de conservação de proteção integral garante condições com baixo grau de interferência antrópica local o que é favorável ao desenvolvimento de modelos conceituais clássicos. A escolha da área ainda se justifica em função da pressão antrópica que existe em sua zona de amortecimento.

Entre os principais pontos a serem esclarecidos, questionam-se:

\section{a) Qual é o conceito de nascente?}

\section{b) Qual é o conceito de vereda?}

\section{c) Qual é o conceito de área úmida?}

\section{d) Quais são os critérios legais vinculados a proteção destes tipos de surgências e/ou zonas de acumulação de água?}

A linha de pesquisa visa enfatizar a proteção da qualidade da água subterrânea e superficial e dos sistemas ecológicos relacionados a nascentes e áreas úmidas, entre as quais veredas e solos com elevado grau de hidromorfismo.

\subsection{APRESENTAÇÃo}

Este trabalho surgiu com o intuito de responder às questões conceituais já citadas para atender a demandas específicas de aplicação da legislação relativa a feições hídricas. Durante a concepção do projeto, as feições eram pensadas de maneira individualizada como: a. Nascentes; b. Veredas; c. Áreas Úmidas, com base nos instrumentos de proteção diferenciados previstos pela legislação florestal brasileira. A proposta era embasar cientificamente o conceito das três feições proeminentemente hidrogeológicas citadas pela Lei 12.651/2012 (Brasil 2012 a), que substituiu o antigo Código Florestal e sistematizar modelos hidrogeológicos para sanar dúvidas de aplicação. No entanto, com o desenvolvimento da análise e maior dedicação ao tema, se ampliou a discussão em uma perspectiva de maior integração das diferentes feições. A conceituação de áreas úmidas demonstrou-se mais ampla e os vários conceitos de diferentes feições a elas relacionadas, que 
inicialmente eram foco de crítica, foram se mostrando mais favoráveis à aplicação diante da complexidade dos contextos encontrados na natureza.

A avaliação integrada supera a lei florestal que inicialmente motivou as questões a serem esclarecidas pela pesquisa, e extrapola exclusivamente a ciência hidrogeológica na sua sistematização e modelagem - ainda que dela obtenha contribuições importantes. Os conceitos de nascentes, veredas e áreas úmidas passam por tratados internacionais e são discutidos em diversas políticas nacionais: Política Nacional de Meio Ambiente; Política Nacional de Áreas Protegidas; Política Nacional de Biodiversidade; Política Nacional de Educação Ambiental; Plano Nacional de Gerenciamento Costeiro; Política Nacional de Recursos Hídricos. Enquanto o conceito de nascentes é estritamente hidrogeológico, os conceitos de áreas úmidas e veredas são multidisciplinares. Ainda assim, mesmo o conceito puramente hidrogeológico de nascentes é múltiplo em funções ambientais.

A partir da visão integrada, veredas são consideradas como uma classe de áreas úmidas, cujo elevado grau de hidromorfismo é o critério identificador e a fitofisionomia, o critério tipificador. Nascentes e cursos de água são vistos como integrantes da rede fluvial regular. Acredita-se que o sistema bem definido de instrumentos legais integrados seja favorável à proteção de ambientes aquáticos e de ambientes transicionais, com suas funções interações ambientais garantidas.

\subsection{Problemas NOS CONCEITOS DE NASCENTES, VEREDAS E ÁREAS ÚMIDAS}

Os problemas abordados referem-se à conceituação, determinação e caracterização de nascentes, veredas e áreas úmidas em casos controversos, com implicações práticas em processos nos quais há atuação do Poder Público, motivados pelas possíveis irregularidades em APP. Entre os pontos que esta dissertação busca esclarecer, citam-se:

- Quais fatores determinam as surgências e/ou acúmulos de água em certas áreas?

- Quais as possíveis classificações dessas surgências/ou acúmulos de água?

- Em que casos as surgências e/ou acúmulos implicam na necessidade de algum tipo de proteção legal?

- Quais as funções ambientais desempenhadas por surgências e/ou acúmulos de água que justificam a sua proteção?

- Quais são as previsões legais para a proteção de alguns desses tipos de surgências e/ou acúmulos de água?

- A temporalidade (sazonalidade, intermitência ou perenidade) das surgências e/ou de acúmulos superficiais de água tem influência sobre sua determinação e caracterização?

- O contexto regional tem influência sobre a determinação e caracterização de surgências 
e/ou acúmulos de água superficial?

- Surgências e/ou acúmulos superficial de água de origem antrópica devem implicar em determinação de áreas protegidas?

- Como analisar surgências e/ou acúmulos superficial de água naturais potencializados, perenizados, ou ainda, sazonalizados, direta ou indiretamente, pela interação de atividades antrópicas quanto à necessidade de proteção ambiental?

- Quais são as possíveis sugestões de aperfeiçoamento da legislação no que diz respeito a nascentes, veredas e áreas úmidas?

- Quais as diferenças entre os modelos propostos para as distintas feições?

\subsection{JUSTIFICATIVAS}

A necessidade de conceituação, determinação e caracterização de nascentes, veredas e áreas úmidas têm importantes implicações sobre o uso e ocupação do solo. O estudo aprofundado do tema justifica-se não apenas pela aplicação no esclarecimento de questões judiciais, mas também pela necessidade de estabelecimento de modelos conceituais técnicos, que colaborem com a contínua construção da ciência hidrogeológica, por meio de discussões, revisões e atenção à temática específica. O levantamento bibliográfico indica que a conceituação, determinação e classificação de nascentes, veredas e áreas úmidas ainda constituem tema a ser explorado e aperfeiçoado.

A elaboração de pesquisas semelhantes para dirimir polêmicas sobre a aplicação de conceitos técnicos do Código Florestal por outras instituições de geociências do Brasil reforça a relevância da ampliação das discussões a respeito das definições previstas na legislação ambiental. Em 2008, o Instituto Geológico de São Paulo publicou livro sobre o tema Restinga (Souza 2008), com ampla revisão conceitual sobre o tema diante das controvérsias que o Código Florestal vigente na época já apresentava (Brasil 1965).

Com as discussões sobre a superveniência da Lei 12.651/12 (Brasil 2012 a), o Instituto Nacional de Ciência e Tecnologia em Áreas Úmidas - INAU compilou e divulgou estudos sobre as deficiências nas previsões da nova legislação, entre os quais o material digital "Classificação e Delineamento das Áreas Úmidas Brasileiras e de seus Macrohabitats”. O texto aborda o tema com informações detalhadas sobre duas grandes Áreas Úmidas do Brasil - a Amazônia e o Pantanal de acordo com a chave de classificação proposta. A obra, lançada com proposta colaborativa na rede mundial de computadores, tornou-se livro em 2015 (Cunha et al. 2015). Nele consta registrada a necessidade de levantamentos de áreas úmidas para todas as regiões brasileiras, de acordo com critérios adaptados à realidade nacional de grande complexidade de contextos. A partir da 
estimativa de que $20 \%$ do território brasileiro seja coberto por áreas úmidas (Junk et al. 2011), estimula os esforços de estudos como base para uma nova política de proteção e manejo sustentável. Esta dissertação justifica-se também como fonte de contribuição para os conhecimentos sobre as áreas úmidas de pequenas dimensões no Cerrado, com base no estudo de caso aplicado na ESEC-AE Águas Emendadas.

\subsection{ObJetivos}

Este trabalho objetiva contribuir com a revisão dos conceitos, além de propor método integrado para a caracterização e determinação de nascentes, veredas e áreas úmidas, aplicado em estudo de caso na Estação Ecológica de Águas Emendadas - DF. A pesquisa na ESEC-AE procura acrescentar um sistema de avaliação de processos de alterações ambientais em relação às feições hídricas. A caracterização e a determinação das feições hidrológicas oferecem como produtos o desenvolvimento de cenários temporais e de modelos conceituais com fundamentação hidrogeológica/pedológica para o esclarecimento de impasses quanto à aplicação da lei e suas implicações. Além disso, esta dissertação busca agregar reflexões às demandas de tutela em processos judiciais nos casos reais submetidos à análise pericial, com sugestões de alternativas para proteção em condições de fragilidade ambiental.

\subsection{ESTRUTURA DA DISSERTAÇÃO}

Esta dissertação estrutura-se em três blocos para o desenvolvimento do tema "Nascentes, Veredas e Áreas Úmidas". Cada bloco, correspondente a um capítulo, é representado por cor diferente no "Fluxograma 1 - Estrutura da Dissertação" (Figura 1).

No primeiro bloco (Capítulo 2), propõe-se a revisão conceitual das citadas feições hídricas. A revisão baseia-se em referenciais teóricos sobre a diversidade de uso dos termos e explora as definições em três linhas de uso:

- Definições informais: senso comum, regionalismos e correspondência dos termos em línguas estrangeiras;

- Definições técnico-científicas;

- Definições legais: acordos internacionais, legislação federal e outros instrumentos normativos.

Como a imprecisão das definições legais tem implicações jurídicas e práticas, o bloco 1 oferece análise mais detalhada sobre a aplicação dos conceitos conforme a lei quanto à proteção prevista e às fragilidades nos conceitos legais. A citação de casos reais, selecionados no acervo de informações técnicas elaboradas por equipes de peritos, exemplifica algumas das possíveis 
implicações jurídicas. O produto resultante da análise das questões do primeiro bloco é a proposta conceitual, fundamentada nas definições técnico-científicas e na indicação de soluções para a aplicação dos conceitos conforme a lei.

Mas não basta definir novos conceitos; é importante refletir sobre como aplica-los. Por este motivo, a partir da revisão conceitual de nascentes, veredas e áreas úmidas, este trabalho propõe método de determinação e de caracterização das feições para a adequada aplicação dos instrumentos de proteção no segundo bloco (Capítulo 3):

- Primeira etapa - determinação: Obtenção de dados, por meio de levantamentos espaciais e temporais, realizados tanto em campo, como por meio de pesquisas bibliográficas. Como produto da fase de determinação, elaboram-se os cenários espaço-temporais da área de estudo, com base em critérios identificadores e critérios temporais das feições.

- Segunda etapa - caracterização: Descrição das feições quanto aos critérios tipificadores. Isto permite o desenvolvimento de modelos conceituais do contexto das feições hídricas, produtos da integração da primeira e segunda etapas.

- Terceira etapa - aplicação dos instrumentos de proteção: Utilização dos modelos conceituais para a reflexão sobre a adequada aplicação dos instrumentos de proteção caso a caso.

Esse processo sistematizado permite contribuir com o aperfeiçoamento do conceito das feições e com a aplicação da legislação para a devida proteção.

O terceiro bloco apresenta a aplicação do método proposto no estudo de caso da Estação Ecológica de Águas Emendadas (Capítulo 4), com detalhamento de materiais e métodos específicos ao caso. Com base nos resultados, o trabalho agrega a aplicação dos conceitos de nascentes, veredas e áreas úmidas, a partir da adequada caracterização e determinação de feições, e traça sugestões de aperfeiçoamento da legislação brasileira quanto às feições hídricas de maneira integrada, além de prever desmembramentos de questões para futuras análises na ESEC-AE (Capítulo 5). 


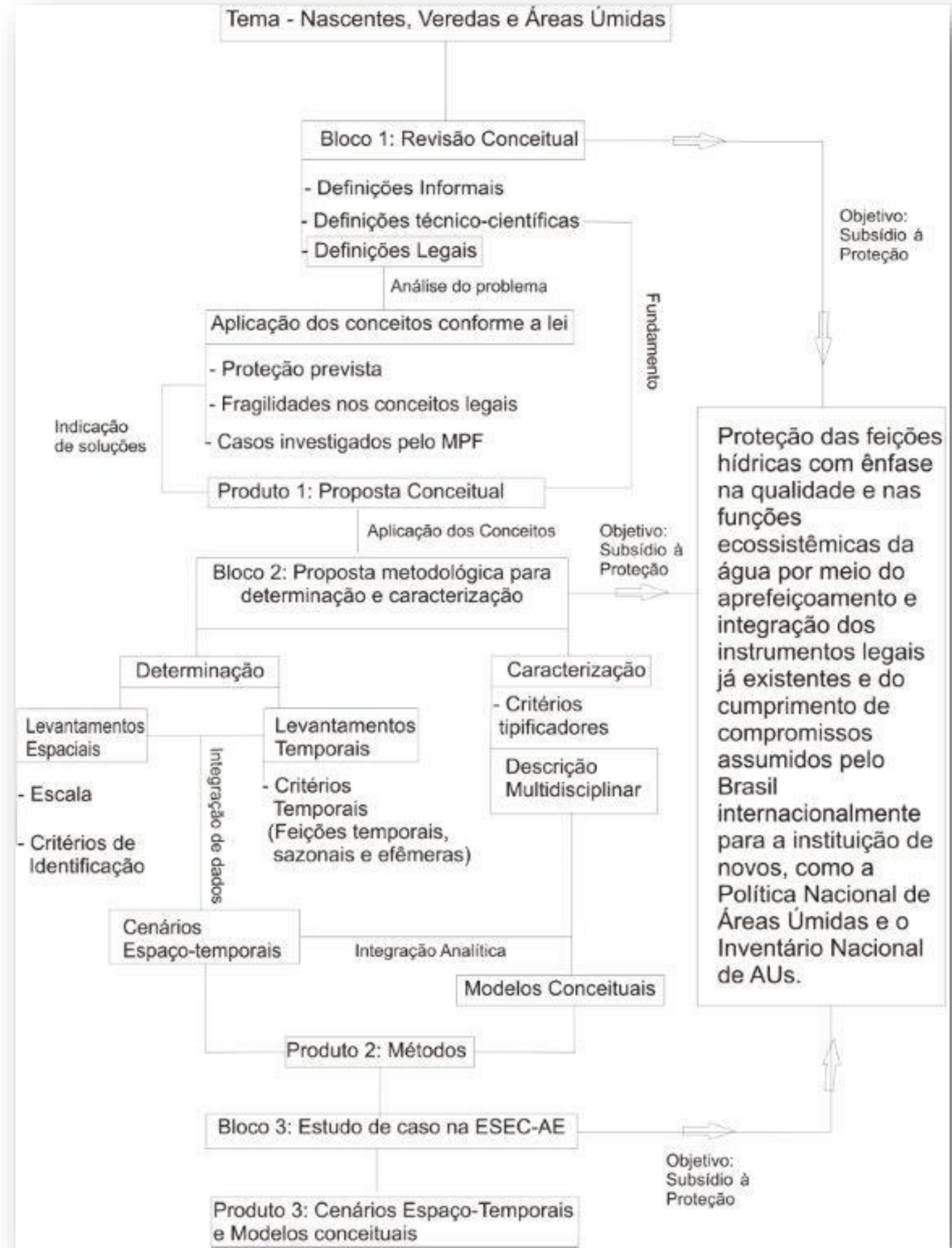

Figura 1 - Fluxograma de estrutura da dissertação. 


\section{CAPÍTULO 2 \\ REVISÃO CONCEITUAL}

Os conceitos de nascentes veredas e áreas úmidas não são precisos. Estes termos são aplicados geralmente em três contextos: no uso informal, nas discussões técnico-científicas e em situações práticas balizadas na legislação. No uso informal e nas discussões técnico-científicas a mistura dos termos não necessariamente representa um problema de aplicação.

O senso comum, os regionalismos e as distinções na correspondência dos termos em diferentes línguas são manifestações legítimas de designações que comunidades com determinadas tradições terminológicas, de diferentes regiões e/ou até mesmo de diferentes países adaptam às suas necessidades de se referir às citadas feições.

Também a comunidade científica na discussão sobre os termos manifesta-se legitimamente e acrescenta ao processo de construção da ciência, sob a óptica de diferentes especialidades ou vertentes. Essa é inclusive uma das propostas desse trabalho: a discussão sobre os conceitos, com base em fundamentos e pesquisa, mas com a consciência de que é apenas uma contribuição sujeita à dinâmica de acréscimos e alterações.

No entanto, na aplicação prática balizada nos preceitos legais, a busca pela precisão dos termos é necessária à potencialização do exercício da justiça. Nesse caso, a aplicação de termos mesclados é um problema prático e não apenas um aspecto conceitual. Deste modo, é necessário que as leis tenham um bloco de definições claro e bem respaldados na ciência. As controvérsias conceituais de nascentes, veredas e áreas úmidas têm importantes implicações jurídicas. De acordo com a legislação brasileira, nascentes, veredas e áreas úmidas apresentam instrumentos jurídicos de preservação diferenciados, com garantias ambientais variáveis de acordo com cada definição de tipologia.

A importância de se buscar a precisão dos vocábulos é fundamental e corresponde à base de qualquer ciência, pois quando todos os envolvidos não consideram a correspondência dos mesmos atributos a um conceito há dificuldade de entendimento e de contribuição para o avanço do conhecimento naquele tema específico. A abordagem deste referencial teórico propõe uma reflexão acerca de termos controversos, sob o ponto de vista técnico e legal, incluindo nascentes, veredas e áreas úmidas.

2.1 DEFINIÇÕES INFORMAIS: SENSO COMUM, REGIONALISMOS E CORRESPONDÊNCIA DOS TERMOS EM LÍNGUAS ESTRANGEIRAS

\subsubsection{Senso Comum}

A análise do senso comum baseia-se nas noções comumente admitidas pela maioria das 
pessoas. Por esse motivo, a análise adotada neste tópico parte dos conceitos difundidos por obras de referência1 - empregadas nesta dissertação como sinônimos de dicionários e enciclopédias, com base em Booth et al. (2008). As obras de referência explicitam a dificuldade de dissociação dos sentidos dos verbetes em questão, elencados a seguir:

\section{a) Nascentes}

Segundo o Dicionário Houaiss (Houaiss \& Villar 2009), no que tange aos recursos hídricos, nascente é: "Ponto onde nasce um curso de água; cabeceira, fonte". Já o Dicionário Aurélio da Língua Portuguesa (Ferreira 2010) classifica o termo como "Lugar onde nasce o curso de água; cabeceira".

Em dicionários da língua portuguesa, portanto, "nascente" envolve a noção de lugar onde nasce o curso d'água, o que é, em parte, a concepção adotada pela legislação ambiental brasileira vigente. Entretanto, os sinônimos são "fonte" ou "cabeceira", vocábulos que recebem distintos significados e que ampliam as questões de emprego adequado. Um exemplo de dificuldade no emprego do conceito de nascente é o ponto de determinação da cabeceira de um rio na gestão de bacias hidrográficas, visto que é variável em função de questões temporais, climáticas, geomorfológicas e antrópicas.

\section{b) Veredas}

O verbete "vereda", identificado em dicionários, é amplo e regionalizado. Em dicionários de geociências não consta a expressão "vereda", o que induz a concepção de seu caráter predominantemente fitofisionômico.

Em relação às veredas, o Dicionário Houaiss da Língua Portuguesa (Houaiss \& Villar 2009), as define como:

Caminho estreito, senda; caminho secundário pelo qual se chega mais rapidamente a um lugar, atalho; orientação de uma vida, de uma ação; rumo, direção, caminho; terreno brejoso, situado em encosta, geralmente perto de cabeceira de rio e coberto com vegetação rasteira; na região da zona das caatingas, área com maior abundância de água e de vegetação, localizada entre montanhas; em Goiás, várzea ao longo de um rio; em Minas Gerais, região dos cerrados, curso de água orlado por buritizais.

O Dicionário Aurélio da Língua Portuguesa (Ferreira 2010) traz definições semelhantes:

Caminho estreito, senda; atalho; rumo, caminho, direção; ocasião, momento, oportunidade; no nordeste do Brasil, região mais abundante de água na zona da caatinga, entre as montanhas e os vales dos rios, e onde a vegetação é um misto

1 Segundo Booth et al. (2008), há dois tipos de obras de referência geral: os dicionários ou enciclopédias mais especializadas. Elas fornecem visões gerais sobre os tópicos de pesquisa. 
de agreste e caatinga; planície e em Minas Gerais e Goiás, cabeceira e curso de água orlados de buritis, especialmente na zona sanfranciscana.

A polissemia do termo "vereda" segundo os dicionários reflete o senso comum regionalizado e amplia o emprego do verbete. Os diversos significados mesclam os conceitos por convergência de sinônimos com áreas úmidas e nascentes, como em "terreno brejoso" e proximidade a "cabeceiras", respectivamente.

\section{c) Áreas Úmidas}

Nenhum dos dois dicionários da língua portuguesa consultados - Houaiss (Houaiss \& Villar 2009) e Aurélio (Ferreira 2010) - conta com a definição para áreas úmidas. Neste caso, a avaliação do senso comum baseia-se no emprego difundido na mídia e no meio público oficial. Assim, admite-se a noção de áreas úmidas como sinônimo de zonas úmidas, estabelecida pela Convenção de Ramsar.

O conceito de Zonas Úmidas adotado pela Convenção de Ramsar (detalhado no tópico 2.3.1) é abrangente e compreende, além de diversos ambientes úmidos naturais, também áreas artificiais, como represas e açudes. A inclusão de áreas artificiais decorre do fato de que, originalmente, a Convenção se destinava a proteger ambientes utilizados por aves aquáticas migratórias, que as utilizam para pousio e reprodução. Segundo o conceito estabelecido pela Convenção de Ramsar, veredas, olhos d'água e outros corpos d'água efêmeros estão inclusos com áreas ou zonas úmidas. No Brasil, o uso da expressão "áreas úmidas” parece prevalecer sobre "zonas úmidas".

\subsubsection{Regionalismos}

Os termos referentes a nascentes, veredas e áreas úmidas variam nas regiões do Brasil, possivelmente não apenas em função das particularidades de vocabulário, mas da complexidade das configurações das feições. Entre os termos relacionados ou inter-relacionados a nascentes, veredas e áreas úmidas, citam-se, de maneira meramente exemplificativa e em rol não taxativo:

- Fonte

- Mina de água

- Minadouro

- Lacrimal

- Cabeceira

- Olho d'água

- Buritizal

- Várzea

- Varjão

- Vargem

- Brejo

- Pântano 
- Pantanal

- Banhado

- Branquilhal

- Campina

- Campinarana

- Carnaubal

- Baixadas litorâneas (restinga)

- Turfeiras

- Igapó

- Lagunas costeiras

- Lavrados

- Manguezal

- Restinga

- Turfeiras

- Campo úmido

- Charco

- Encharcado

- Prado

- Áreas saturadas

- Solos hidromórficos

- Mananciais

- Corixo

- Mata turfosa; paludosa

- Mata alagada

- Lagoa

- Vereda

- Caxetal

- Chavascal

- Aguada

- Veio d’água

Vários dos termos citados são classes de áreas úmidas pela "Classificação e Delineamento das Áreas Úmidas Brasileiras e de seus Macrohabitats” (Cunha et al. 2015).

\subsubsection{Correspondências dos Termos em Línguas Estrangeiras}

A correspondência dos termos em línguas estrangeiras é outro fator que tende a generalizar os conceitos. A equivalência dos termos é limitada pelas particularidades e diferenças de condicionantes ambientais de cada área geográfica.

"Spring”, palavra em inglês que designa "nascente", é também traduzida como fonte e manancial. Leinz (1982) conceitua nascente como "fonte" e acrescenta os correspondentes em inglês (spring); alemão (quelle) e francês (source).

A expressão em língua inglesa "wetland" possui como sinônimos palavras correspondentes a pântano, pantanal, turfeira, brejo, charco, prado encharcado, zona úmida, área saturada. Em espanhol, o correspondente é "humedal", frequentemente traduzido para a língua portuguesa do 
Brasil como pantanal. "humedal” também apresenta variações na língua espanhola: "bofedal" e "vado", quando conectado à rede de drenagem e "vega" nos casos em que a água é estancada (senso comum difundido no Chile). Na língua portuguesa de Portugal, aparentemente o termo mais comum em referência a áreas úmidas é charco (correspondente à “charca” na língua espanhola e “pond” em língua inglesa). Portugal possui um inventário de charcos².

O termo "vereda" aparece na literatura adaptado para a língua inglesa como "palm swamp" (Barberi et al. 1999) - correspondente, em tradução livre, a pântano de palmáceas. Na Venezuela, encontram-se os "morichales", cuja correspondência com a vereda e buritizais é irrefutável pela predominância da palmeira Mauritia flexuosa, lá conhecida como “moriche” (Figura 2).

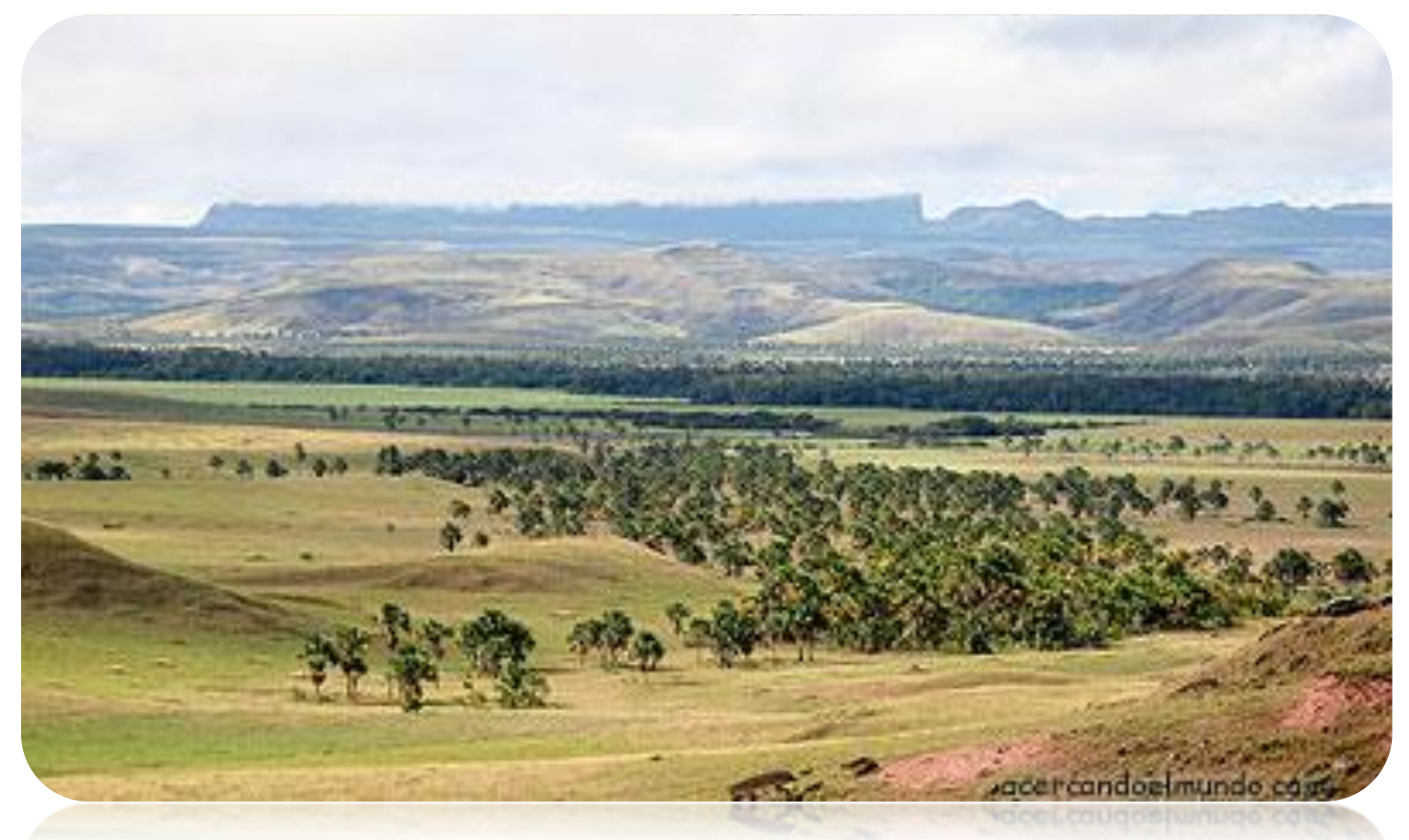

Figura 2 - "Morichales" em Gran Sabana - Venezuela. Buritizal em contexto de savana. Fonte: <http://www.acercandoelmundo.com/contenidostemas/contenidos.asp?id=342 >. Acesso: 22 nov. 2015.

\subsection{Definições técnico-científicas}

\section{a) Nascentes}

O Dicionário Geológico-Geomorfológico (Guerra \& Guerra 2009) define nascente como equivalente a cabeceira de um rio. Segundo os autores, geralmente não é um ponto e sim uma zona considerável da superfície terrestre. Conceituam cabeceira como: “área onde existem os olhos d'água que dão origem a um curso fluvial; é o oposto de foz”. Os autores argumentam que não se deve pensar que a cabeceira seja um lugar bem definido, pois pode constituir uma verdadeira área. Em casos assim, enfocam "uma série de problemas não menos difíceis, como o da escolha de um

\footnotetext{
${ }^{2}$ Disponível em: <http://www.charcoscomvida.org/charcos/manifesto-dos-charco>. Acesso em: 9 jun 2015.
} 
critério para a determinação do rio principal".

Guerra \& Guerra (2009) citam as cabeceiras do rio Amazonas para exemplificar essa dificuldade. Subentende-se que o problema levantado diga respeito à exigência de um ponto de determinação da cabeceira de um rio para definições formais exigidas e o fato de que a sazonalidade pode transformar cabeceiras, segundo a concepção por eles defendida, em grotas secas durante meses com restrição de chuvas. Nesses casos, pode haver o deslocamento periódico do ponto de surgência para montante ou jusante, o que depende diretamente do regime pluviométrico e da variação sazonal da superfície potenciométrica no aquífero (Figura 3).

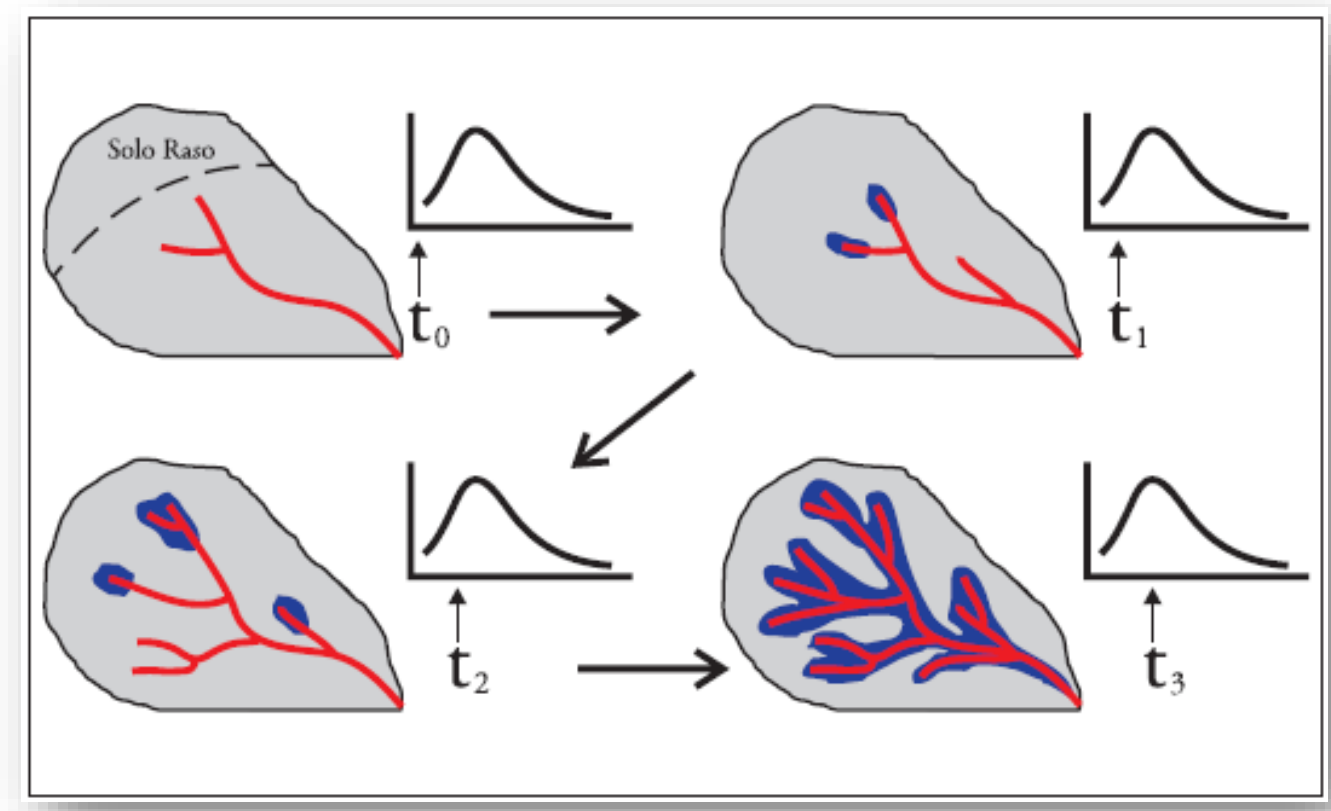

Figura 3 - Contexto de cabeceira: no tempo inicial $\left(t_{0}\right)$, ocorrem as grotas secas em função dos baixos níveis de precipitação. À medida que a frequência de chuvas aumenta ao longo do tempo $\left(t_{1}, t_{2} e t_{3}\right)$, ocorrem as surgências a partir das quais se desenvolvem fluxos d'água. Os solos em volta da linha do talvegue vão ficando saturados. Hewlett apud Baptista in Seduma (2008).

Essa interpretação se baseia na classificação de cabeceiras de drenagem em anfiteatro do citado Dicionário Geológico-Geomorfológico (Guerra \& Guerra 2009), que aborda o tema: "Cabeceira de drenagem em anfiteatro" - tradução da terminologia (amphitheaterlike heads) proposta por Hack \& Goodlett (1960). Referem-se a bacias, ou vales não canalizados, denominadas bacias de ordem zero. São caracterizadas por uma conformação topográfica côncava em planta, correspondentes aos primeiros formadores da rede de drenagem, podendo constituir o prolongamento direto da nascente dos canais fluviais de $1^{\mathrm{a}}$ ordem. São também os tributários laterais de fluxos canalizados de qualquer nível hierárquico, correspondendo a feições geomorfológicas muito frequentes em domínios morfológicos de encostas recobertas por espessos regolitos, em ambiente tropical e subtropical úmido.

Outro conceito de cabeceira abordado por Guerra \& Guerra (2009) que requer critérios 
quanto a aplicações ambientais práticas é o de cabeceira (topo) da voçoroca: "tradução para o termo em inglês headcut. É a parte mais elevada de uma voçoroca, que tende a recuar por erosão remontante. Caracteriza-se por possuir encostas abruptas, podendo apresentar desníveis acentuados".

Os sinônimos de "cabeceiras" enumerados por Guerra \& Guerra (2009) são: nascente, fonte, minadouro, mina, lacrimal, pantanal, manancial. Novamente, neste ponto, ressalta-se o problema retórico de significados comuns aos outros termos discutidos nesta dissertação, como "pantanal" utilizado com frequência para definir "áreas úmidas", e "cabeceiras", um dos elementos que geralmente compõem a definição de veredas.

O Vocabulário Básico de Recursos Naturais e Meio ambiente (IBGE 2004) também interrelaciona os termos nascente e cabeceira, ao definir cabeceira como "porção superior de um curso d'água, próximo a sua nascente".

As classificações de nascentes pelas obras de referência técnicas consultadas são estabelecidas pelo termo "fonte”. O Dicionário Geológico-Geomorfológico (Guerra \& Guerra 2009) define como fonte: "lugar onde brotam ou nascem águas". Segundo os autores, a fonte é “um manancial de água, que resulta da infiltração das águas nas camadas permeáveis”. Cabe ressaltar que esses conceitos adotados para classificação de fontes diferem das definições utilizadas em obras acadêmicas e/ou técnicas de hidrogeologia - ou as simplifica sobremaneira. O mesmo ocorre no que tange à nascente de falha: "se origina através da alimentação de água subterrânea, que sobe por uma falha".

A classificação de nascentes, veredas e áreas úmidas é útil para a etapa de caracterização de feições hídricas (tópico 3.2). Citam-se aqui algumas das classes a fim de registrar a sobreposição de conceitos, tendo em vista de que algumas definições de olhos d'água, áreas úmidas e veredas podem se integrar com diferentes classes de nascentes.

As classes variam de acordo com os parâmetros considerados. Segundo Guerra \& Guerra (2009), há quatro tipos de fontes, em função da topografia e da posição do aquífero: “1. Fontes ordinárias, fixas ou de afloramento; 2. Fontes de vales, também chamadas de talvegues ou móveis; 3. Fontes em repuxo ou artesianas; 4. Fontes voclusianas ou torrenciais". Listam-se a seguir os conceitos de Guerra \& Guerra (2009) empregados em dissonância com o rigor da ciência hidrogeológica:

1. Fonte ordinária, fixa ou de afloramento: “formada por aquíferos que se encontram no limite de uma camada permeável que repousa sobre uma camada impermeável. Chama-se também "fixa" essa fonte porque não varia de posição, pois o afloramento do aquífero está situado no limite da camada permeável, que repousa na impermeável”.

2. Fonte de vale ou de talvegue: "formada por aquífero, cortado em seu trajeto pelo talvegue 
de um vale. Estas fontes são chamadas de móveis, por causa da altura em que o aquífero aflora, segundo se considera a época das chuvas, ou a estação seca”.

3. Fonte artesiana ou poço artesiano: "são mananciais que aparecem à superfície graças a diferenças de pressão hidrostáticas".

4. Fonte Voclusiana: “manancial d'água que aparece em regiões cársticas, constituindo um fenômeno de ressurgência. Estas fontes, também chamadas e fontes torrenciais, não passam de verdadeiros rios sumidos que ressurgem num determinado ponto (ressurgência). O nome advém da fonte Vaucluse nos Alpes Franceses".

Guerra \& Guerra (2009) incluem em sua classificação outros tipos de fonte com base em atributos diversos, que não "a topografia e a posição em relação ao aquífero":

- Fonte de falha: "aparece na natureza em consequência de falhamento, onde as camadas permeáveis se encontram com as impermeáveis".

- Fonte mineral: “denominação usada para as águas ricas em sais. Podem ser águas ferruginosas, magnesianas, sulfurosas e radioativas".

- Fonte surgente: “aquela cujo aquífero se encontra entre duas camadas impermeáveis. Este tipo de aquífero é também chamado de aquífero cativo ou artesiano. $\mathrm{O}$ aparecimento de tais fontes se dá graças ao fato de a água se acumular sob pressão. Pode surgir por uma fenda natural ou por uma perfuração. As fontes artesianas aparecem à superfície, graças à pressão hidrostática".

- Fonte termal: “aquela cujas águas são mais quentes que a temperatura ambiente, como é o caso de Poços de Caldas e Araxá (MG), Cipó (BA), etc. Ainda entre as fontes termais podemse incluir os geysers e as que ocorrem em terrenos fraturados".

Esta dissertação desaconselha o uso dos termos referentes a nascentes sem o devido rigor hidrogeológico para fundamentar as definições da legislação e, consequentemente, sua aplicação. Entre os autores de referência, recomendam-se Fetter (2001), cujos modelos conceituais inspiraram os elaborados neste trabalho, e Kresic \& Stevanovic (2009), com obra completa dedicada exclusivamente ao tema.

Kresic \& Stevanovic (2009) consideram que todas as nascentes têm exsudação à superfície devido à força da gravidade - exceto algumas associadas a vulcanismo recente e atividade hidrotermal. Assim, nascentes são usualmente divididas em dois grupos, com base na natureza da carga hidráulica do aquífero: nascentes de gravidade e nascentes artesianas.

1. Nascentes de gravidade (gravity spring): “emergem sob condições não confinadas onde o nível de água intersecta a superfície”.

2. Nascentes artesianas (artesian spring): “exsudam sob pressão devido a condições confinadas no aquífero subjacente". Também são chamadas de nascentes ascendentes (ascending ou 
rising springs).

A partir da classificação baseada em critérios de natureza do aquífero e da superfície potenciométrica, Kresic \& Stevanovic (2009) listam os diversos tipos de nascente citados a seguir:

- Nascente difusa (seepage spring - Figura 4) é um termo usado para indicar descarga difusa de água, usualmente em sedimentos inconsolidados, como areia e cascalho, ou em solo desagregado.

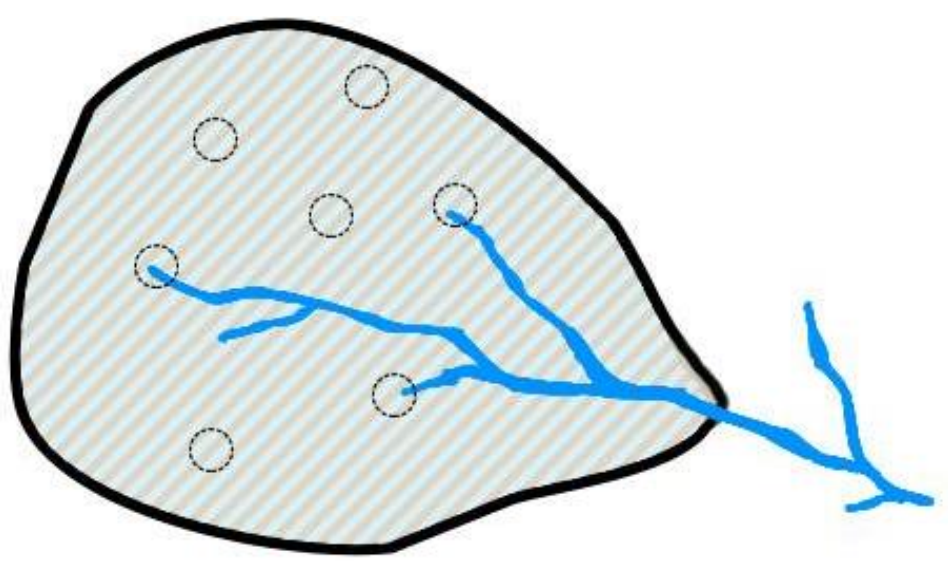

Figura 4 - Nascentes difusas em contexto de solo hidromórfico.

- A nascente de fratura (fracture spring - Figura 5a) ou de fissura (fissure spring - Figura 5b) se refere à descarga de água concentrada de planos de acamamento, juntas, clivagem, falhas e outras fissuras em rochas consolidadas.

a

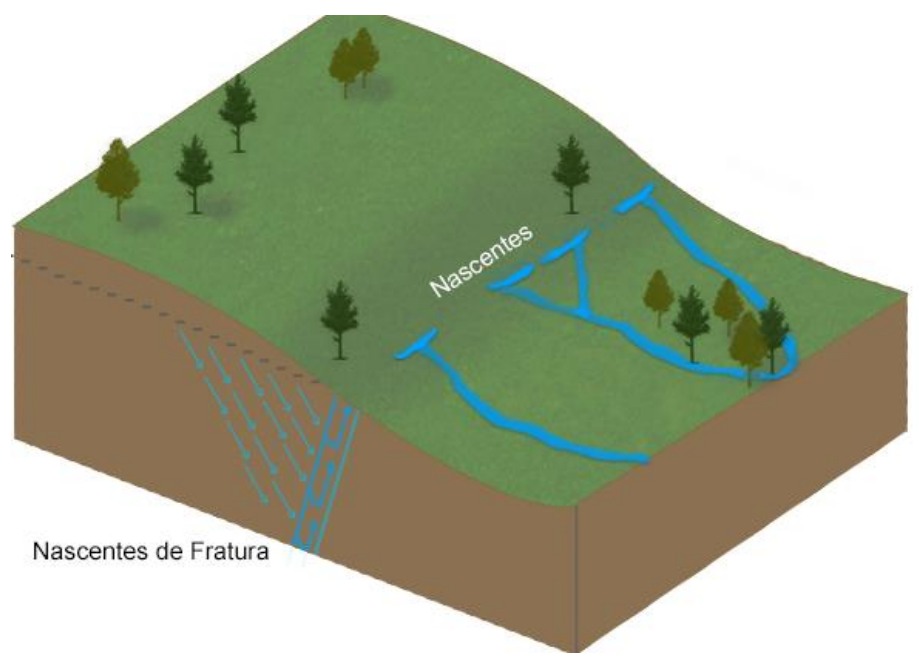




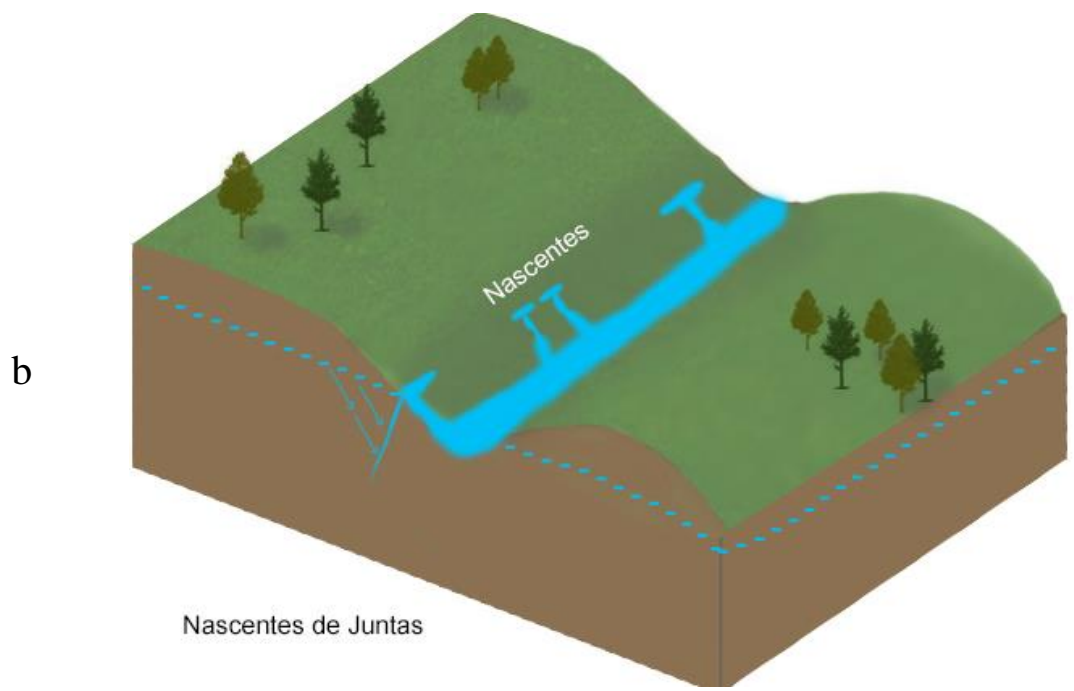

Figura 5 - Nascentes controladas por estruturas rúpteis. Nascentes de fraturas (a) e nascentes de juntas (b). Figuras adaptadas de Fetter (2001).

- Nascente tubular (tubular spring) ou de caverna (cave spring - Figura 6) é o fluxo de aberturas relativamente grandes nas rochas em terrenos cársticos.

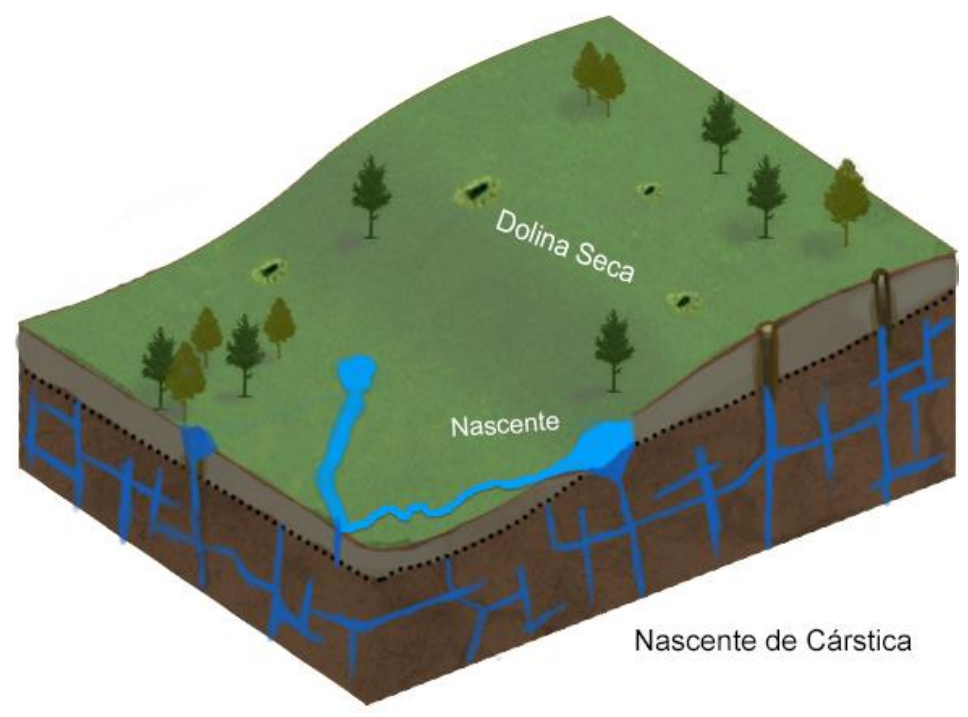

Figura 6 - Nascentes tubulares em sistema cárstico. Adaptada de Fetter (2001).

- Nascente secundária (secondary spring - Figura 7) diz respeito a locais afastados da exsudação da nascente primária, que é coberta por coluvião - fragmentos de rocha rolados ou outros detritos - e, portanto, não visualizável. 


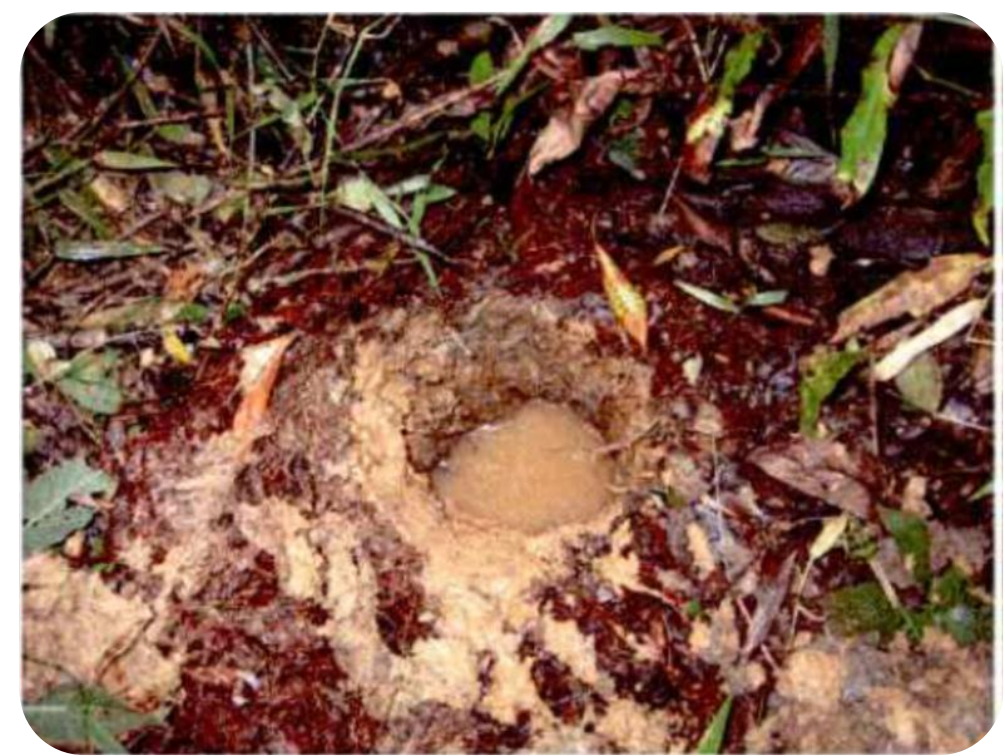

Figura 7 - Solo com elevado grau de hidromorfismo em contexto de depósitos coluvionares na Serra do Itatiaia/RJ. Nascente primária não é visível. Fonte: arquivo do MPF.

- Nascente termal (thermal spring - Figura 8) é aquela que apresenta temperatura elevada em função do gradiente geotérmico da crosta terrestre, devido a alguma situação complexa, que pode forçar a água de maior profundidade a ascender até a superfície. Exemplo: contexto de barreira lateral impermeável em rocha fraturada, causada por falha, que leva a água quente a sedimentos aluviais em um curso de água em um vale, gerando nascente termal. Nesses casos, água subterrânea de temperatura mais fria pode emergir em uma nascente "fria", no contato com sedimentos de textura mais fina, como lama. Uma terceira nascente pode, ainda, estar presente no sistema com a temperatura variável devido ao padrão de precipitações, influências sazonais e mecanismos de mistura de água de diferentes temperaturas.

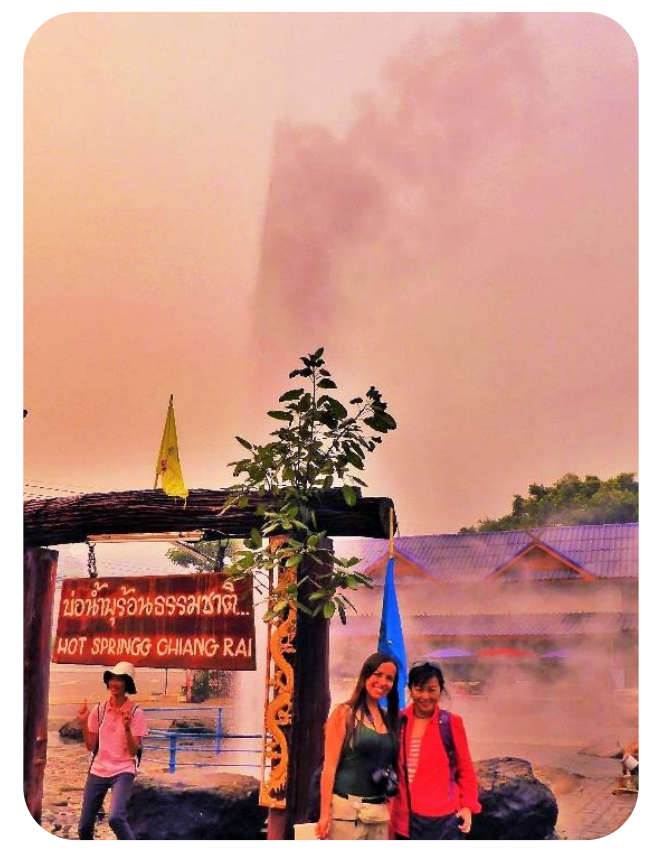

Figura 8 - Nascente artesiana e termal, Chiang Rai - Tailândia. 2014. Fonte: arquivo pessoal. Créditos: Sandra Nami Amenomori e Mariana Cortes. 
- Nascente de depressão (depression spring - Figura 9) é formada em aquíferos não confinados quando a topografia intersecta o nível de água no aquífero, devido a uma incisão do curso de água. Nascentes de depressão que drenam grupos locais de fraturas interconectadas são comuns em aquíferos fraturados e não são necessariamente associadas com um curso de água superficial. Qualquer depressão erosional que intercepte fraturas com água pode causar a emergência de uma nascente.

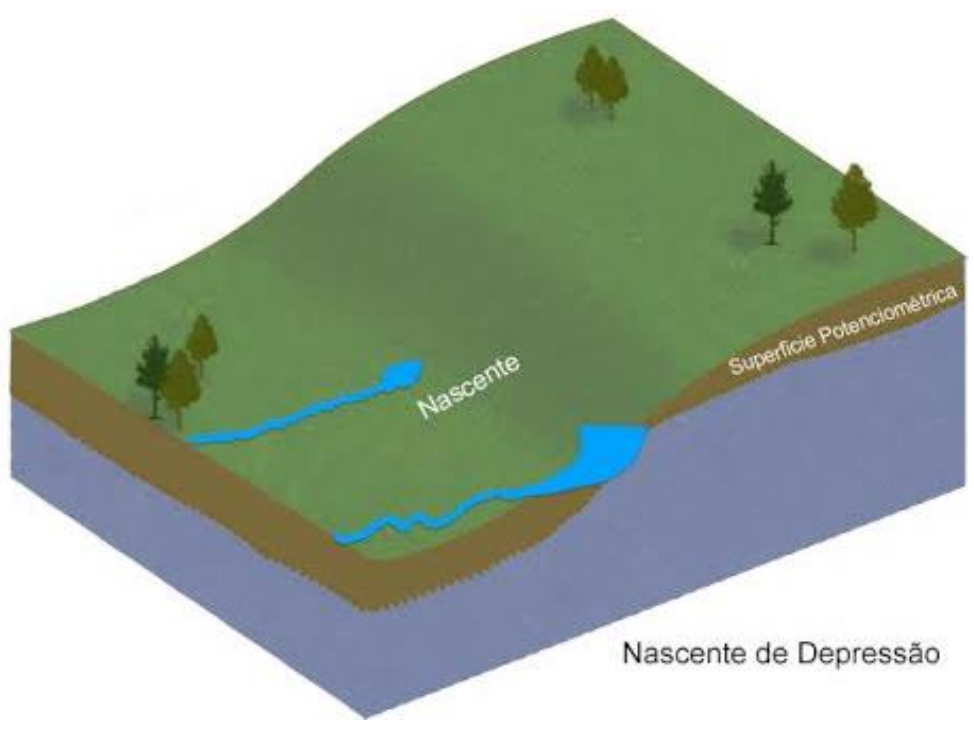

Figura 9 - Nascentes de depressão. Adaptada de Fetter (2001).

- Nascente de contato (contact spring - Figura 10): quando o curso de água superficial corta camadas alternadas de rochas sedimentares permeáveis e impermeáveis, as nascentes de depressão originais podem se transformar em nascentes de contato em várias cotas de elevação acima do canal do curso de água.

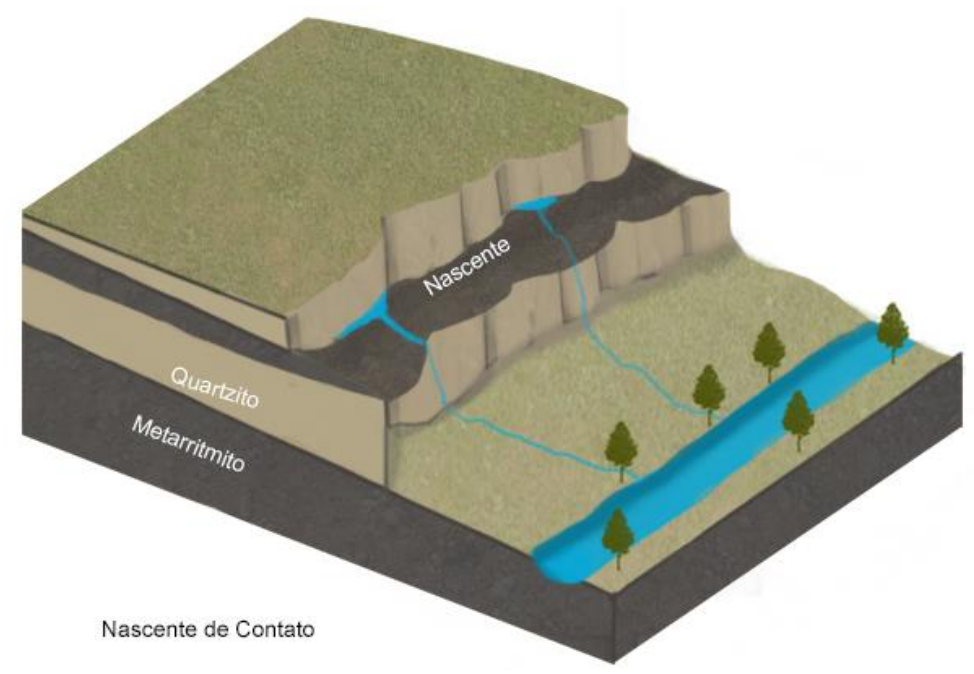

Figura 10 - Nascente de contato. Adaptada de Fetter (2001).

- Nascente de barreira (barrier spring - Figura 11) se refere a nascente em contato lateral entre o aquífero e uma rocha de baixa permeabilidade. O contato pode ter muitas formas, causadas por processos deposicionais e movimentos tectônicos (Kresic \& Stevanovic 2009). 


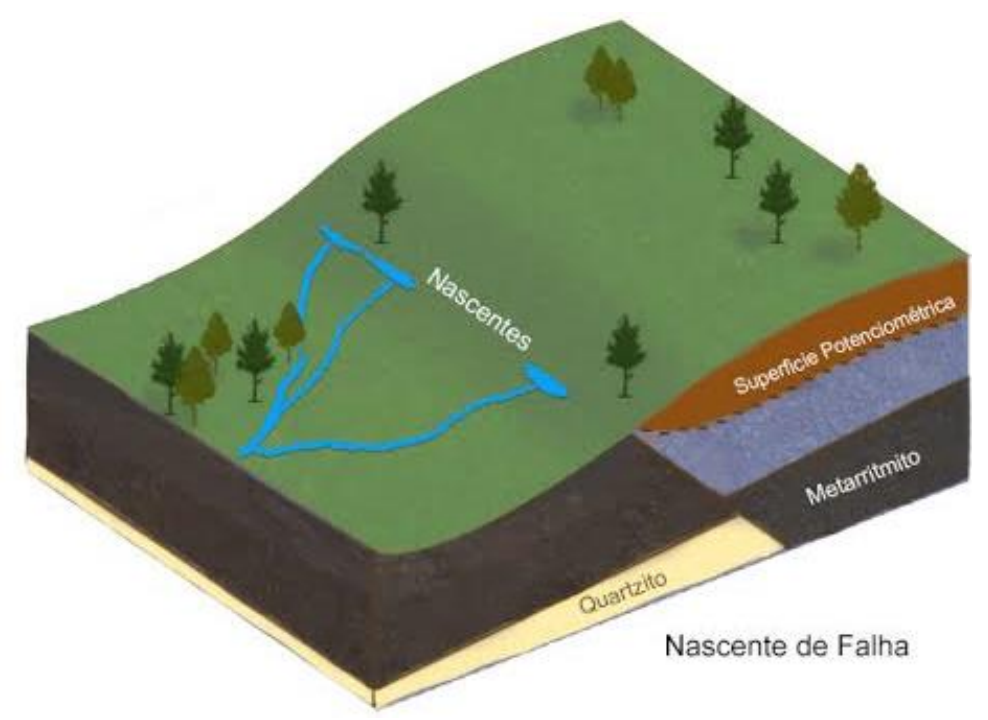

Figura 11 - Nascente de barreira. Contato lateral entre o aquífero e rocha de baixa permeabilidade causado por falha. Adaptada de Fetter (2001).

- Nascente intermitente (intermittent spring - Figura 12) exsuda por somente um período de tempo, enquanto por outros períodos seca, devido ao padrão de recarga do aquífero. Kresic $\&$ Stevanovic (2009) citam que podem ocorrer em variados tipos de rochas, mas que as mais fascinantes são as de aquíferos cársticos. As rochas carstificadas podem receber episódios de precipitação e rapidamente transmitir a água por uma nascente anteriormente seca. As nascentes de fluxo de vazante (ebb-and-flow) ou nascentes periódicas são geralmente encontradas em terrenos cársticos. A descarga ocorre em intervalos relativamente uniformes (períodos) e a explicação é a existência de um sifão rochoso por trás da nascente. $\mathrm{O}$ sifão se enche e se esvazia com regularidade, a despeito do padrão de recarga pluvial. As dolinas (estavelle) têm uma função dupla: agem como uma nascente e como sumidouro.

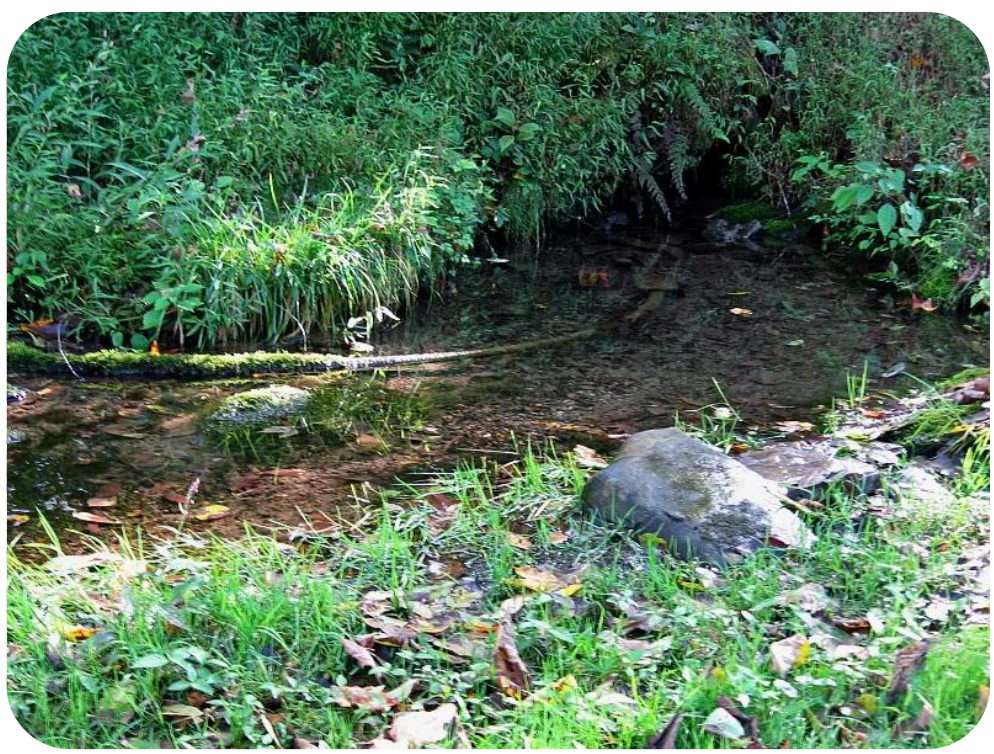

Figura 12 - Nascente intermitente: "Ebbing and Flowing Spring" no estado americano do Tennessee. No período de três horas passa por ciclo desde um filete de água a vazão de $1900 \mathrm{l} / \mathrm{min}$. Fonte: <http://offbeattenn.com/truly-rarespring-ebbs-flows-like-ocean-every-three-hours/>. Acesso em: 22 nov. 2015. 
- Paleonascentes (paleosprings - Figura 13 "a" e "b") são lugares de exsudação de nascentes, atualmente abandonados. Depósitos de travertino distantes de nascentes permanentes ou cursos de água superficial são bons indicadores de atividade de formação de nascentes e podem indicar a presença de nascentes próximas.

a

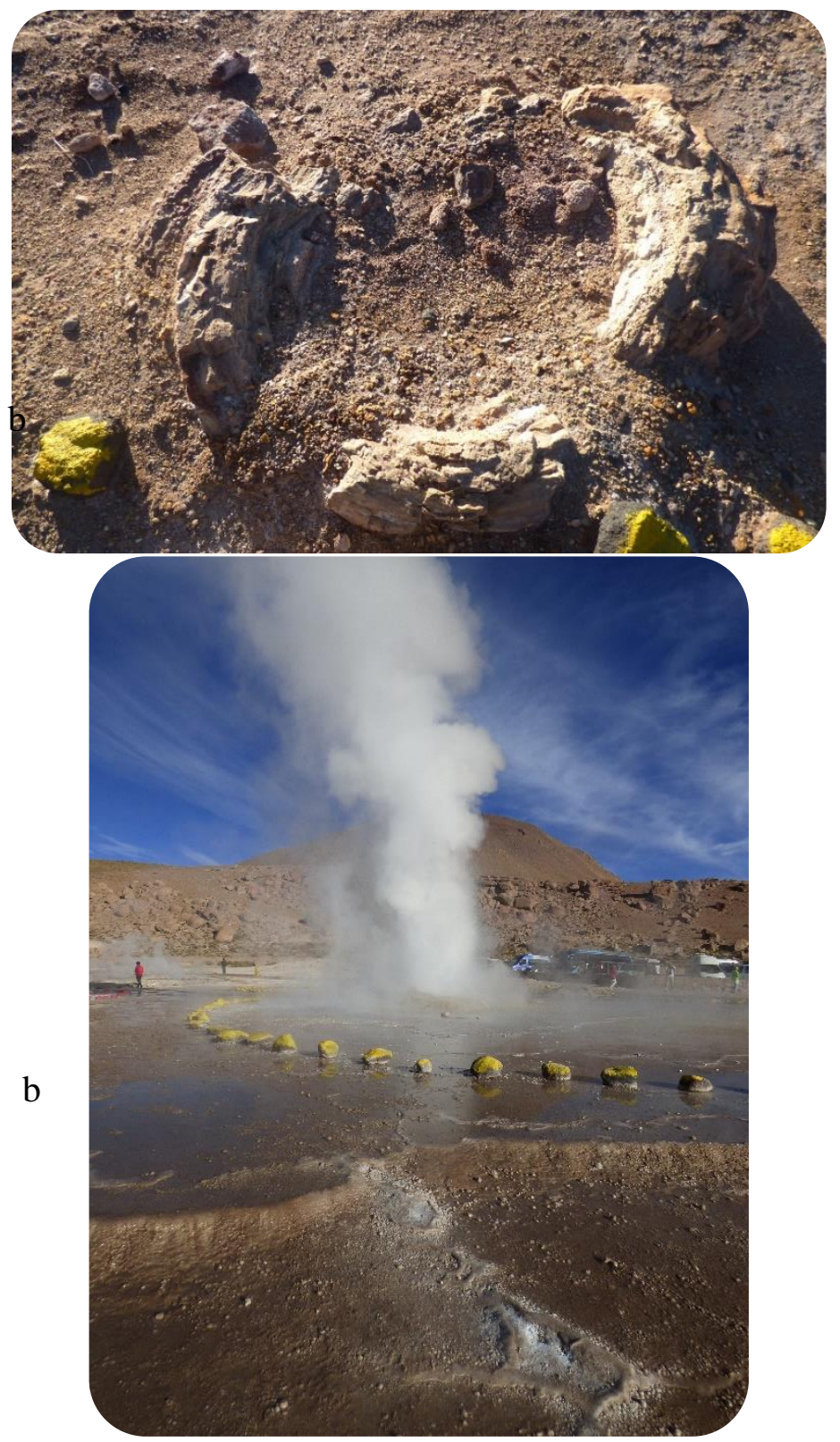

Figura 13 - Paleonascente (a). Depósito de travertino (b) em contexto de nascentes (gêiseres) - El Tatio, Atacama/Chile. Fonte: arquivo pessoal.

- Nascentes submersas (submerged springs): a descarga de água subterrânea para os corpos hídricos superficiais está, em muitos casos, abaixo do nível de água e não é imediatamente visível (Figura 14). Essa descarga pode ser tanto difusa ou concentrada na forma de nascentes submersas. 


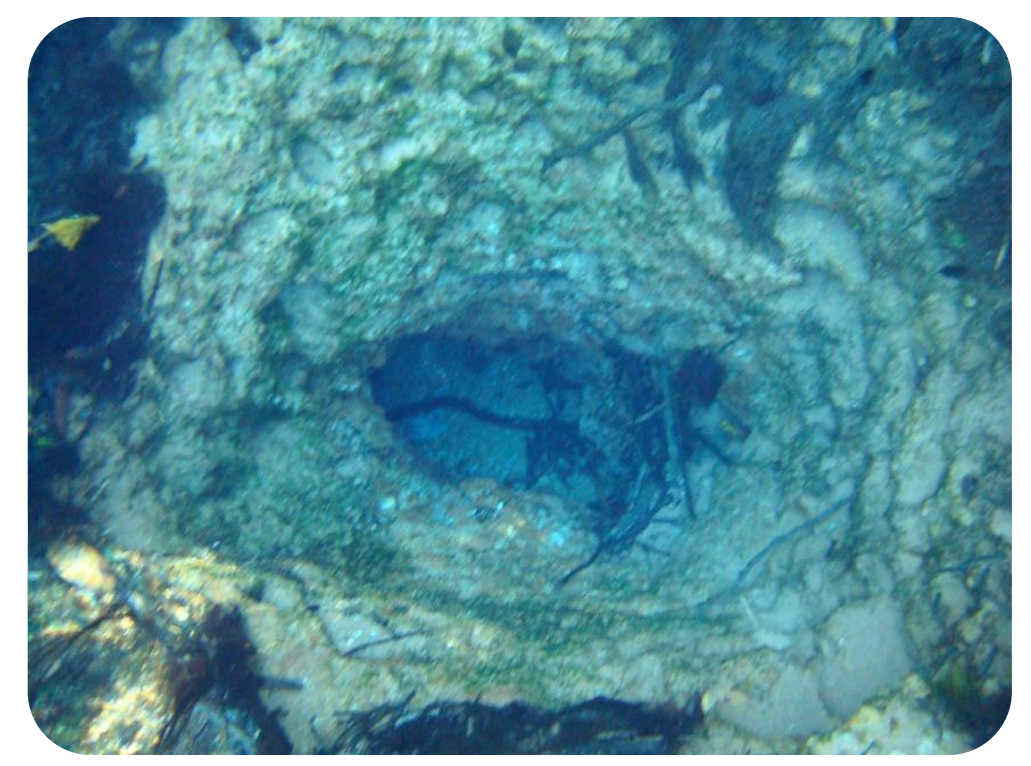

\section{Figura 14 - Nascente submersa no Rio da Prata -- Bonito/MS. Fonte: arquivo} pessoal.

Nascentes de água doce com exsudações do assoalho oceânico têm intrigado as pessoas por milênios (Kresic \& Stevanovic 2009). Um geógrafo romano que viveu de 63 AC a 21 DC, mencionou uma nascente de água doce submarina a $4 \mathrm{~km}$ de Latakia, Síria, perto das ilhas mediterrâneas de Aradus. A água dessa nascente era coletada por um barco, com o uso de um funil condutor e um tubo de couro e transportada para a cidade como uma fonte de água doce. O fluxo de água subterrânea para a costa e a descarga submarina são causados pelo gradiente hidráulico entre as áreas de recarga continentais e o assoalho oceânico. Se o aquífero é confinado e bem protegido por um aquitarde espesso, o fluxo de água subterrânea pode continuar muito além da linha de costa com a última exsudação em um afloramento distante do aquífero submarino.

- Gêiseres (geysers) e fumarolas (solfataras): são geralmente encontrados em regiões de atividade vulcânica recente (Kresic \& Stevanovic 2009). A água da superfície se infiltra através das rochas abaixo da superfície terrestre a regiões de alta temperatura ao redor de um reservatório de magma, tanto ativo quanto solidificado, mas ainda aquecido (Figura 15). Lá a água é aquecida, se torna menos densa e sobe à superfície por fissuras. Às vezes essas feições são chamadas de vulcões "moribundos", pois aparentemente eles representam o último estágio da atividade vulcânica enquanto o magma esfria e litifica em profundidade. Os gêiseres promovem espetáculos de liberação de energia repentina, mas seus mecanismos não são completamente compreendidos. Presume-se que grandes quantidades de água preencham cavidades subterrâneas. A água aquecida é violentamente ejetada quando uma porção dela repentinamente se torna vapor. Um ligeiro decréscimo de pressão ou um aumento de temperatura fazem a água ferver. $\mathrm{O}$ vapor resultante força a água sobrejacente a 
subir pelo conduto até a superfície. Essa perda de água reduz a pressão dentro do sistema de conduto e a maioria da água remanescente repentinamente se converte em vapor e entra em erupção até a superfície. Esse ciclo pode ocorrer com notável regularidade. As fumarolas, que emitem misturas de vapor e outros gases, são alimentadas por condutos que passam pelo nível de água até atingir a superfície do terreno. O sulfeto de hidrogênio $\left(\mathrm{H}_{2} \mathrm{~S}\right)$, que é um dos gases típicos das fumarolas, prontamente oxida para ácido sulfúrico e enxofre nativo. Isso contribui com a intensa atividade química e com a coloração das rochas em muitas áreas termais.

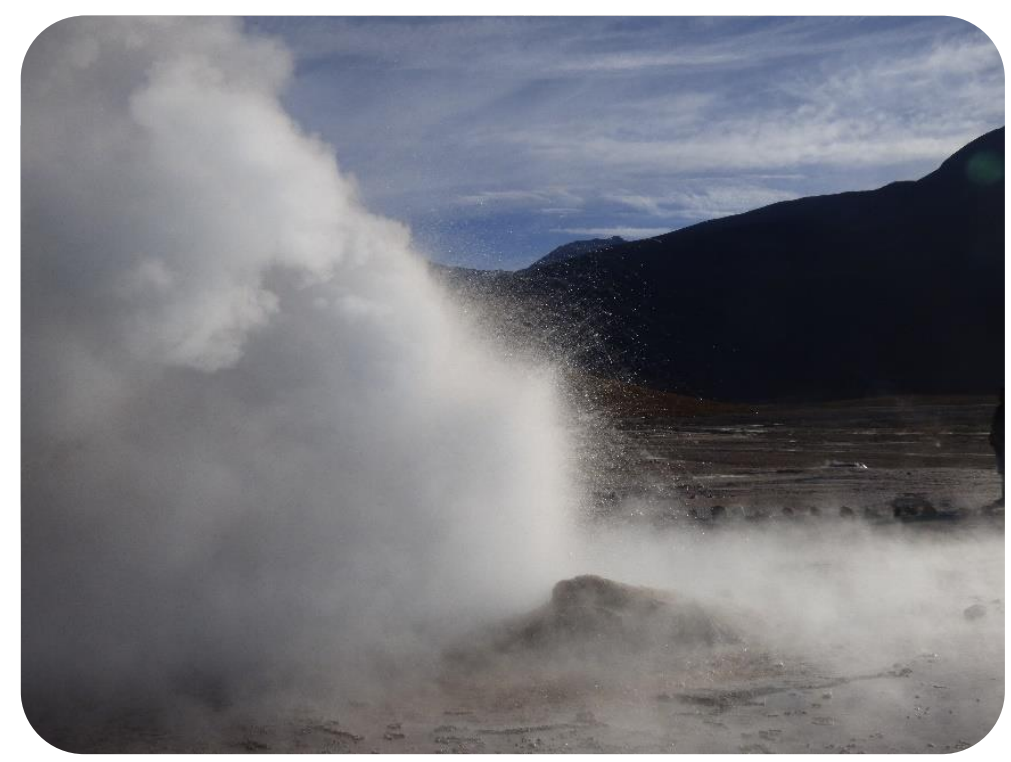

Figura 15 - Gêiser em El Tatio - Atacama/Chile. Fonte: arquivo pessoal.

Por fim, Kresic \& Stevanovic (2009) relatam que para a organização dos supracitados tipos de nascentes há diversos critérios de classificação propostos. Os mais comuns são:

- Taxa de recarga e uniformidade;

- Caráter da superfície potenciométrica que origina a descarga (nascentes de gravidade ou descendentes; e nascentes artesianas ou ascendentes);

- Estruturas geológicas e geomorfológicas de controle da descarga (nascentes de depressão, contato, barreira e submersas);

- Qualidade da água e temperatura (fonte de água mineral/termal).

Para Kresic \& Stevanovic (2009), nascente é um local de descarga natural da água subterrânea do aquífero na superfície do terreno de onde se origina um fluxo visível. A causa dessa descarga é a diferença entre a elevação da superfície potenciométrica no aquífero e a elevação da superfície do terreno onde a descarga ocorre. Segundo os autores, quando o fluxo não pode ser imediatamente observado, mas a superfície do terreno é úmida em comparação à área do entorno, a descarga da água subterrânea é chamada de área encharcada (tradução livre de seep). O Manual Técnico de Geomorfologia (IBGE 2009) considera nascentes indeterminadas, em razão da 
presença de pântanos, lagos ou áreas alagadiças, como feições morfológicas anômalas de drenagem.

\section{b) Veredas}

O termo veredas possui duas principais vertentes de conceituação: hídrica/morfológica e fitofisionômica.

O Manual Técnico de Geomorfologia (IBGE 2009) classifica vereda como: zona deprimida de forma ovalada, linear ou digitiforme dentro de área estruturalmente plana ou aplanada por erosão. É resultante de processos de exsudação do lençol freático, cujas águas geralmente convergem para um talvegue, assinalada por vegetação típica, caracterizada por palmeiras de diferentes espécies, particularmente buritis, podendo conter área com turfa. Ocorre nas chapadas das bacias e cobertura sedimentares, bem como em planaltos pertencentes a outras áreas sujeitas à atuação de sistemas morfoclimáticos de cerrado. Já o Manual Técnico de Pedologia (IBGE 2007) relaciona a ocorrência de veredas a solos hidromórficos e ambientes de grande umidade e a "plantas indicadoras", como açaí, buriti e capim redondo.

O termo "veredas" também é costumeiramente conceituado em função de características fitofisionômicas do cerrado (Brandão et al. 1991; Araújo et al. 2002; Walter 2006; Costa 2007; Seduma 2008; Pio 2010; Somavilla 2011; Cunha et al. 2015). Walter (2006) considera veredas como uma fitofisionomia do bioma cerrado que possui um significativo complexo vegetacional (Figura 16), cuja similaridade estatística é maior em relação a Campo Limpo (com 228 espécies em comum) e Campo Sujo (com 183 espécies em comum), ainda que o número de espécies em comum seja maior com a Mata de Galeria (224 espécies) e com o Cerrado sensu stricto (205 espécies). A similaridade considerada no trabalho levava em conta um total de 6024 espécies.

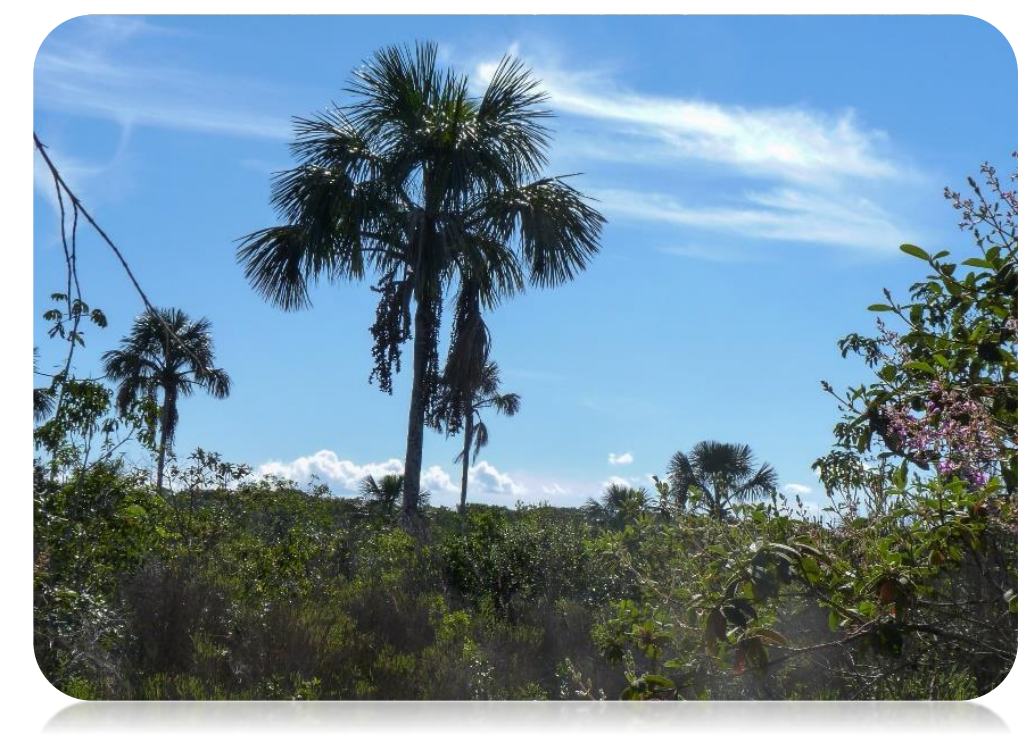

Figura 16 - Complexo vegetacional de vereda na ESEC-AE. Fonte: Carlos Alberto Correia. 
Araújo et al. (2002) também consideram a complexidade vegetacional das veredas e a distribuição das espécies de acordo com o gradiente de umidade no solo entre a borda, o meio e o fundo. A borda é considerada a zona próxima ao cerrado, constituída por solo mais claro e com melhor drenagem; o meio, em solo mais escuro, saturado com água grande parte do ano e o fundo, em solo permanentemente saturado com água e essencialmente orgânico. No trabalho, o autor conclui que algumas espécies como o buriti podem ser exclusivas de veredas, mas ressalva a necessidade de mais estudos para a comprovação dessa ideia.

\section{c) Áreas Úmidas}

O termo "áreas úmidas" é empregado em amplo senso em textos acadêmicos para caracterizar distintas classes de corpos de água que não compõem a rede fluvial regular. O vocábulo é empregado, por exemplo, no complexo de lagoas nas proximidades da Lagoa Mirim, resultantes dos processos de regressão marinha holocênicas ocorridas na área da atual fronteira entre Brasil e Paraguai (Steinke 2007).

A expressão áreas úmidas é, no entanto, mais frequentemente utilizada no sentido de pantanal (Figura 17), tanto na literatura com o uso do termo exato em português (Lima 2011), quanto em publicações na língua inglesa - pela tradução do termo "wetland” (Tiner 1999; Iriondo 2004; Rushton 2006; Campos et al. 2013; Valente et al. 2013).

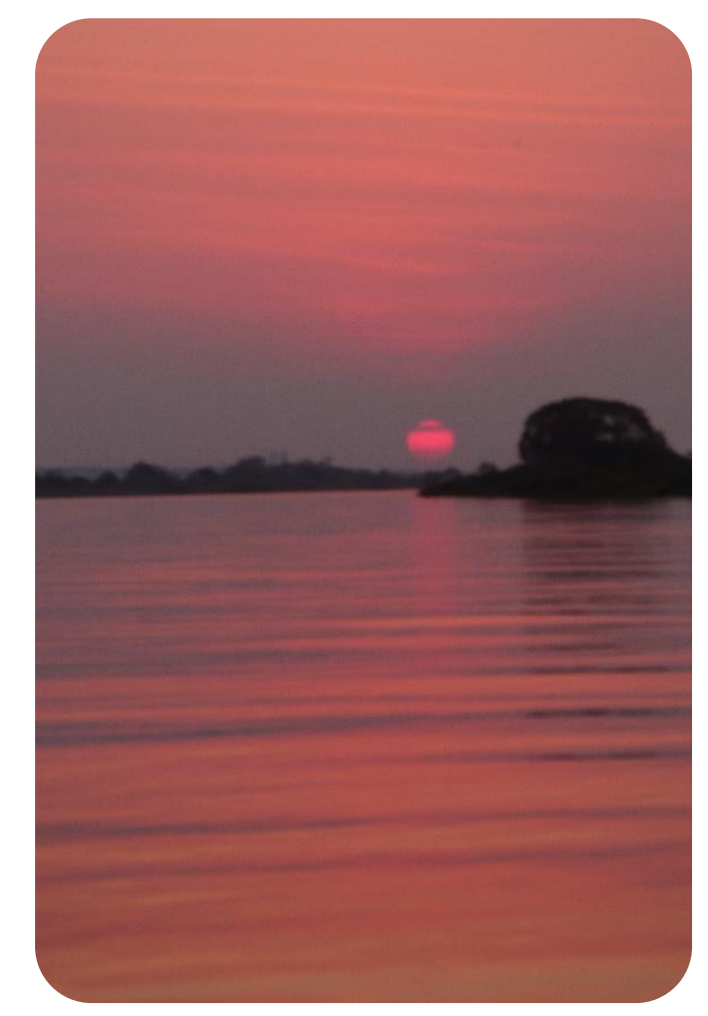

Figura 17 - Pantanal Sul-Mato-Grossense. Rio Corumbá. Fonte: arquivo pessoal. 
A expressão "áreas úmidas" também parece ter emprego em contexto fitofisionômico, como sinônimo de "campo úmido" do cerrado (Mello 2012). Neste contexto ocorrem os campos de murundus associados a áreas úmidas do bioma cerrado. Campos et al. (2013) consideram que no Brasil Central localizam-se áreas de savana constituídas de tipos mais terrestres de áreas úmidas e campo limpo úmido (grassland-type savanna), campo sujo úmido (shrub-type savanna), mata galeria (riverine forest); além de tipos mais aquáticos de áreas úmidas e vereda (valley-side marsh with palm groves of Mauritia flexuosa), várzea (backswamp), lagos e rios. Segundo os autores, essas áreas úmidas são reguladas por um regime climático sazonal caracterizado por estação chuvosa úmida de outubro a março seguida de estação seca. Nos estudos de caso avaliados, Campos et al. (2013) argumentam que cerca de 60\% da variabilidade na distribuição espacial dos tipos de "áreas úmidas terrestres" deve-se a fatores geológicos e geomorfológicos e que nenhum efeito claro de variáveis abióticas foi observado em "tipos mais aquáticos de áreas úmidas". Os autores sugerem uma associação entre camadas geológicas estratificadas ou superfícies planares geológicas, zonas de descarga de água subterrânea e descontinuidades e a ocorrência de áreas úmidas e enfatizam a importância de considerar fatores abióticos para a compreensão mais profunda da distribuição das áreas úmidas tropicais.

Segundo o documento elaborado pelo Centro de Pesquisas do Pantanal - CPP e pelo Instituto Nacional de Pesquisa e Tecnologia em Áreas Úmidas - INAU “Definição e Classificação das Áreas Úmidas (AUs) Brasileiras: Base Científica para uma Nova Política de Proteção e Manejo Sustentável” (2012) e editado e publicado por Cunha et al. (2015), as áreas úmidas são:

Áreas Úmidas (AUs) são ecossistemas na interface entre ambientes terrestres e aquáticos, continentais ou costeiros, naturais ou artificiais, permanentemente ou periodicamente inundados por águas rasas ou com solos encharcados, doces, salobras ou salgadas, com comunidades de plantas e animais adaptadas à sua dinâmica hídrica.

Como critérios essenciais de identificação de áreas úmidas, Cunha et al. (2015) citam: 1. Presença, pelo menos periódica de espécies de plantas superiores aquáticas ou palustres e/ou 2. Presença de substrato/solo hídrico. Para justificar a conceituação proposta, os autores argumentam que:

Considerando o fato de que o pulso de inundação é o fator preponderante na caracterização da maioria das AUs brasileiras, propomos a elaboração de uma definição que inclua todas as áreas cobertas ou encharcadas por água doce ou salinizada, temporárias ou permanentes, até uma profundidade média máxima nas cheias e da maré alta, correspondentes à amplitude media máxima do respectivo pulso de inundação no respectivo local.

Cunha et al. (2015) fazem uma avaliação integrada das áreas úmidas e de sua distribuição no Brasil. Segundo o trabalho, a maioria das áreas úmidas brasileiras é sazonal ou temporária. As 
áreas úmidas com níveis de água oscilantes ao longo de períodos são entendidas a partir da transição entre a fase terrestre e aquática:

A estrutura e o funcionamento das AUs com níveis de água oscilantes são descritos pelo Conceito de Pulso de Inundação (Junk et al. 1989), o qual define, analisa e explica o intercâmbio lateral de água, nutrientes e organismos entre rios ou lagos e as respectivas áreas alagáveis conectadas, definindo processos e padrões de assinatura hidrológica na mudança das condições ecológicas entre a fase terrestre e a aquática. Também estão incluídas nesse conceito as áreas periodicamente alagadas pelas chuvas e pela subida periódica do lençol freático. A sequência de inundação e seca (o pulso de inundação) é a força dominante dos processos ecológicos em AUs de alagamento periódico. As áreas periodicamente alagadas e secas, chamadas de áreas de transição aquático/terrestre [Aquatic Terrestrial Transition, Zone, ATTZ, (Junk et al. 1989)], constituem a maior parte das AUs brasileiras. Em AUs extensas, como as várzeas e igapós amazônicos ou do Pantanal Mato-grossense, as ATTZs são compostas por muitos habitats diferentes e incluem, além das áreas periodicamente secas e alagadas, também habitats permanentemente aquáticos, como lagoas e canais, e terrestres, tais como paleo-várzeas, paleo-dunas e inselberges, que são de importância fundamental para a manutenção da biodiversidade e da produtividade do sistema. [sem grifo no original].

Sobre as classes de AUs terrestres de pequenas dimensões, como as veredas e os solos com condições de hidromorfismo, Cunha et al. (2015) consideram que:

As bordas de AUs pequenas, inseridas na paisagem terrestre, sempre ou periodicamente inundadas, como buritizais, campinas ou campinaranas deveriam ser definidas pelo nível da média máxima da inundação. E, no caso de solos encharcados, da extensão dos solos hidromórficos e da ocorrência de uma vegetação aquática ou pantanosa, adaptada às condições anóxicas do solo, ainda que sazonalmente. [Grifo ausente no original]

Por fim, Cunha et al. (2015) propõem uma chave de classificação das áreas úmidas brasileiras com base em características e elementos específicos que por vezes não são considerados nas chaves de classificação internacionais (Figura 18). 


\section{Sistema Subsistema Ordem Subordem Classe Subclasse Macrohabitat}

\section{AUs costeiras}

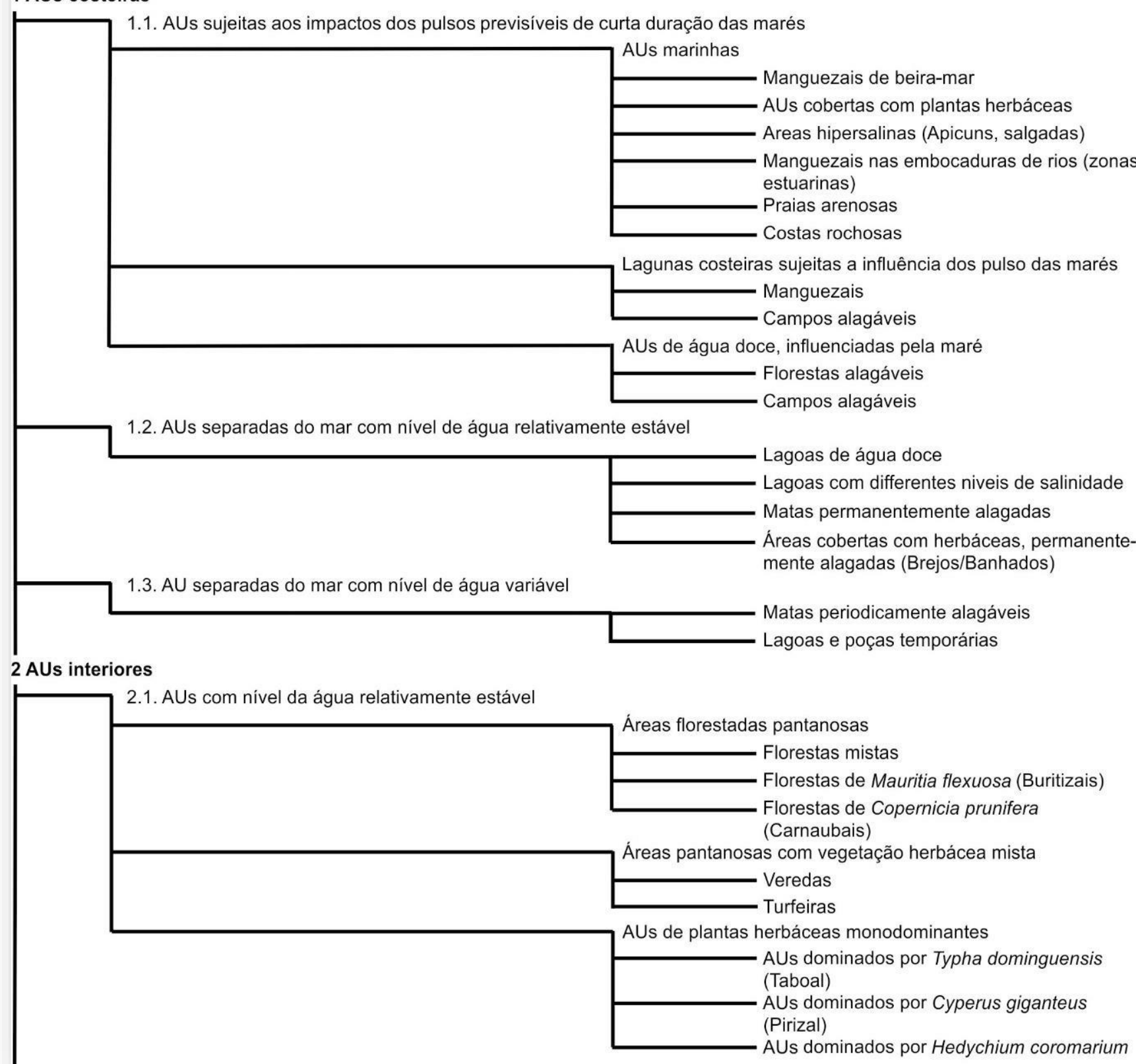


2.2.1. AUs sujeitas a pulsos de inundações previsiveis, monomodais, e de longa duração

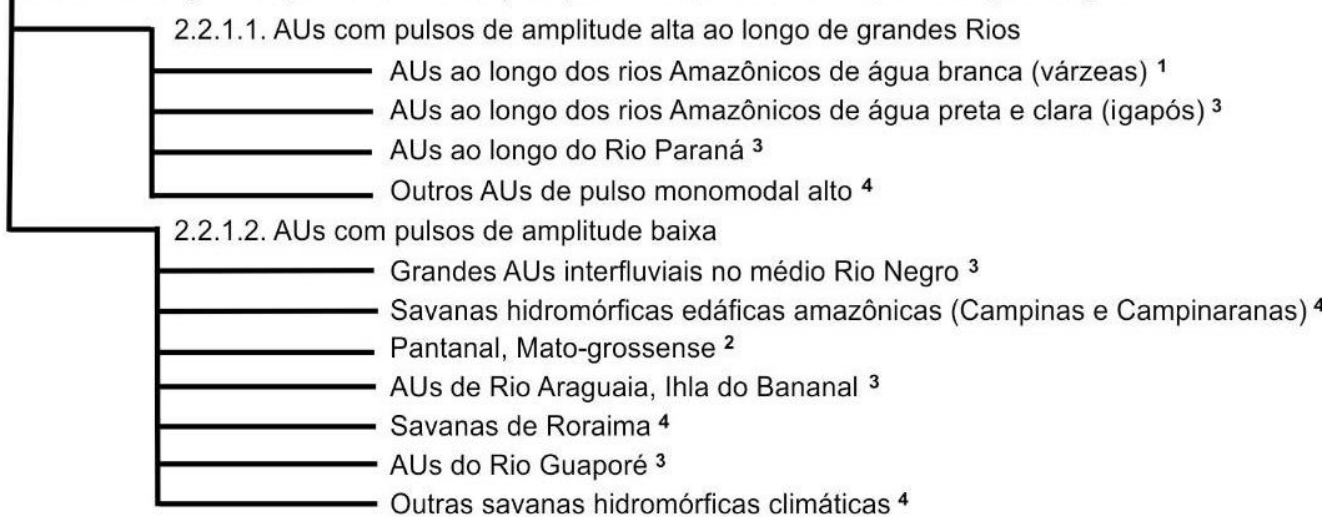

2.2.2. AUs sujeitas a pulsos polimodais imprevisíveis de curta duração
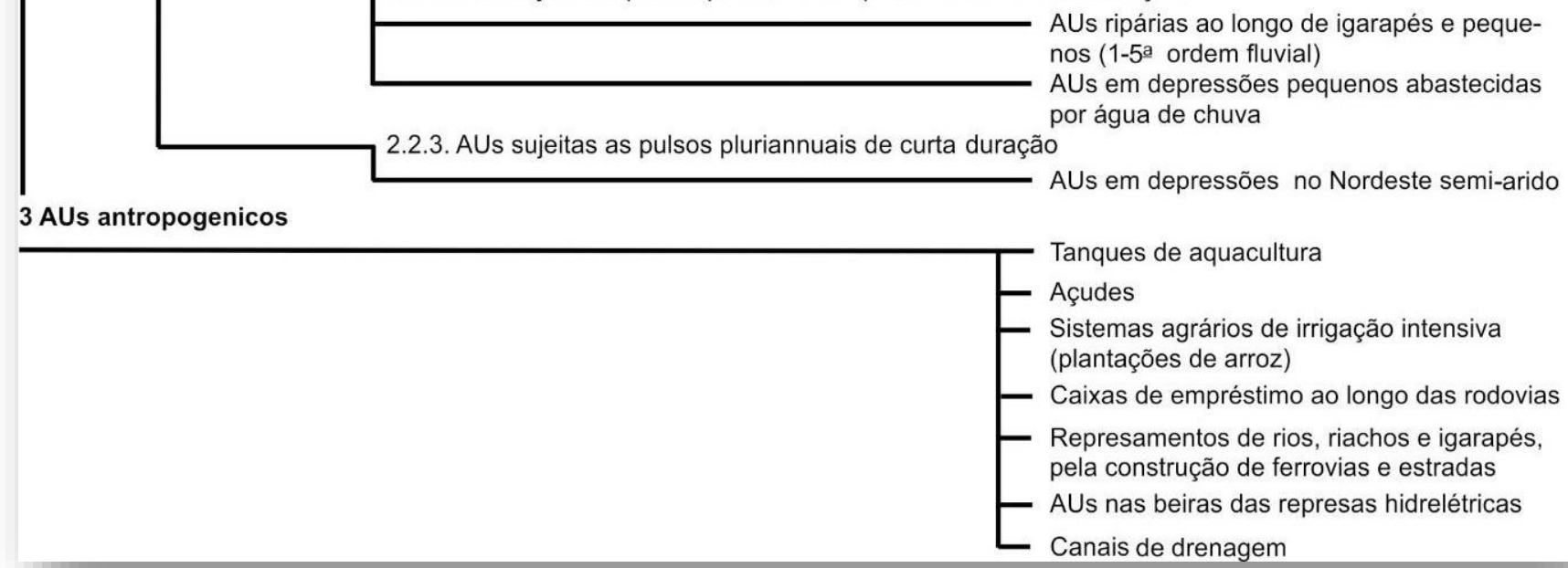

Figura 18 - Classificação das AUs brasileiras. Fonte: Cunha et al. (2015).

Para a determinação espacial de AUs, Cunha et al. (2015) sugerem:

A extensão de uma AU é determinada pelo limite da inundação rasa ou do encharcamento permanente ou periódico ou, no caso de áreas sujeitas aos pulsos de inundação, pelo limite da influência das inundações médias máximas, incluindo-se aí, se existentes, áreas permanentemente secas em seu interior, habitats vitais para a manutenção da integridade funcional e da biodiversidade das mesmas. Os limites externos são indicados pela ausência de solo hidromórfico e/ou pela ausência permanente ou periódica de hidrófitas e/ou de espécies lenhosas adaptadas a solos periodicamente encharcados.

\subsection{DEFINIÇÕES LEGAIS}

As definições empregadas na legislação florestal brasileira são restritivas quanto às nascentes, mas não são quanto a veredas e áreas úmidas. Nos três casos, ambientes de relevância ecológica podem deixar de receber a devida proteção, caso a discussão das definições não sejam aprofundadas a partir do rigor técnico. Além da legislação florestal, o Brasil possui um arcabouço 
legal ambiental com diferentes enfoques quanto aos instrumentos de proteção, que visam restringir os impactos em corpos hídricos e orientar o uso racional desses recursos, pelas múltiplas funções ambientais desempenhadas. Porém, é necessário potencializar a aplicação das normas e aperfeiçoar a integração das políticas nacionais entre si e com tratados internacionais, como, por exemplo, a Convenção de Ramsar.

\subsubsection{Acordos Internacionais}

As três feições naturais em pauta neste trabalho, nascentes veredas e áreas úmidas, despertam a discussão sobre os mecanismos de proteção aos recursos hídricos. Por este ser um tema amplo, estratégico e integrado, tratados internacionais foram estabelecidos com o intuito de alinhar as diretrizes relativas aos recursos hídricos e ações do desenvolvimento sustentável em questões de meio ambiente.

Um dos princípios que rege o direito internacional quanto ao meio ambiente é o de que "Os Estados, de acordo com a Carta das Nações Unidas e com os princípios do direito internacional, têm o direito soberano de explorar seus próprios recursos segundo suas próprias políticas de meio ambiente e de desenvolvimento, e a responsabilidade de assegurar que atividades sob sua jurisdição ou seu controle não causem danos ao meio ambiente de outros Estados ou de áreas além dos limites da jurisdição nacional" (Princípio 2, Declaração do Rio sobre o Meio Ambiente e Desenvolvimento 1992).

Conforme esse princípio, o Brasil dispõe de arcabouço legislativo próprio sobre temas ambientais. As questões de cunho transfronteiriço são, no entanto, negociadas internacionalmente. Entre os três tipos de feições discutidas por esta dissertação, aquele que leva a uma maior discussão conceitual de esfera transfronteiriça/internacional é o referente a áreas úmidas. Isso porque, áreas úmidas são reconhecidas como sinônimo de zonas úmidas, definidas pela Convenção de Ramsar.

As zonas úmidas são protegidas pela Convenção sobre Zonas Úmidas de Importância Internacional, especialmente como Habitat de Aves Aquáticas, também conhecida como Convenção de Ramsar, que foi assinada em 2 de fevereiro de 1971 no Irã e entrou em vigor internacional em 21 de dezembro de 1975. No Brasil, foi promulgada pelo Decreto 1905, de 16 de maio de 1996. O principal assunto dessa convenção é a listagem das zonas úmidas que ostentem importância internacional, segundo os parâmetros da convenção, e a conservação ambiental dessas zonas. Em vários trechos desta dissertação a Convenção de Ramsar é referida simplesmente como Convenção.

A Convenção considera as funções ecológicas fundamentais das zonas úmidas enquanto reguladoras dos regimes de água e enquanto habitas de flora e fauna características, especialmente de aves aquáticas migratórias. As partes se declaram conscientes de que as zonas úmidas 
constituem recurso de valor econômico, cultural, científico e recreativo, cuja perda seria irreparável. Por isso, declaram eliminar, de forma atual e futura a progressiva invasão e perda de zonas úmidas.

A Convenção não faz parte do sistema de tratados internacionais coordenados pela ONU, nem está subordinada a suas agências, mas conta com o apoio oficial de cinco organizações nãogovernamentais internacionais ${ }^{3}:$ Bird Life International, International Union for the Conservation of Nature - IUCN, Wetlands International, International Water Management Institute (IWMI) e a rede conservacionista WWF. No Brasil, a autoridade responsável por coordenar a implementação dos compromissos da Convenção é o Ministério do Meio Ambiente.

Nas Conferências das Partes (Conference of the Parties - COP) os países apresentam suas políticas e atividades para a conservação e uso racional das zonas úmidas, o que permite que o Secretariado acompanhe a implementação da Convenção. O Brasil apresentou relatórios para as COP 8, 9, 10, 11 e 12, realizadas, respectivamente, em 2002, 2005, 2008, 2012, 2015.

De acordo com a Convenção de Ramsar, cada Estado-parte tem obrigações. As que se relacionam mais diretamente às funções hidrológicas das zonas úmidas são:

- Indicação das zonas úmidas em seu território que devam constar na Lista de Zonas Úmidas de Importância Internacional. Descrição pormenorizada e delimitação dos limites das zonas úmidas em mapa, com possibilidade de incorporação de áreas ribeirinhas ou litorais adjacentes às zonas úmidas e ilhas ou porções de água marítima com mais de seis metros de profundidade na maré baixa situada dentro da área de zona úmida, principalmente onde tiverem importância como habitat de aves aquáticas [Art. $2^{\circ}$ (1), Convenção de Ramsar].

- Seleção das zonas úmidas com fundamento da importância internacional em termos ecológicos, botânicos, zoológicos, imunológicos ou hidrológicos. As zonas úmidas de importância internacional para as aves aquáticas em qualquer estação do ano devem ser consideradas em primeiro lugar [Art. $2^{\circ}$ (2), Convenção de Ramsar].

- Planejamento e administração de modo a promover a conservação das zonas úmidas listadas e, na medida do possível, a exploração racional de zonas úmidas, ainda que não listadas [Art. $3^{\circ}$, Convenção de Ramsar, sem grifo no original].

- Promoção da conservação de zonas úmidas e de aves aquáticas, independentemente de estarem listadas, pelo estabelecimento, nelas, de reservas naturais, a serem objeto de proteção apropriada [Art. $4^{\circ}(1)$, Convenção de Ramsar].

- Compensação de eventual redução dimensional de zona úmida listada por meio da

\footnotetext{
${ }^{3}$ Fonte: http://www.mma.gov.br/biodiversidade/biodiversidade-aquatica/zonas-umidas-convencao-deramsar/instrumentos-da-convencao-de-ramsar. Acesso em 26 mai 2015.
} 
criação de novas reservas naturais - à reserva do possível [Art. $4^{\circ}$ (2), Convenção de Ramsar].

No citado artigo $1^{\circ}$ consta a conceituação de zonas úmidas segundo a Convenção de Ramsar: "Para efeitos desta Convenção, as Zonas Úmidas são áreas de pântano, charco, turfa ou de água, natural ou artificial, permanente ou temporária, com água estagnada ou corrente, doce, salobra ou salgada, incluindo água marítima com menos de seis metros de profundidade na maré baixa" [Tradução oficial constante no Decreto 1.905/1996, sem grifo no original].

No Brasil, algumas zonas úmidas já constam listadas como zonas úmidas de importância internacional. Essas áreas são reconhecidas como Sítios Ramsar e necessariamente correspondem a Unidades de Conservação estabelecidas, o que favorece a adoção das medidas necessárias à implementação dos compromissos assumidos pelo país perante a Convenção. Atualmente, são doze os Sítios Ramsar no Brasil (Tabela 1).

Tabela 1 - Zonas úmidas brasileiras incluídas na Lista Ramsar ${ }^{4}$.

\begin{tabular}{|l|c|c|}
\hline \multicolumn{1}{|c|}{ Sítios } & UF & Data da inclusão \\
\hline 1. Área de Proteção Ambiental das Reentrâncias Maranhenses & MA & $30 / 11 / 1993$ \\
\hline 2. Área de Proteção Ambiental da Baixada Maranhense & MA & $29 / 02 / 2000$ \\
\hline 3. Parque Estadual Marinho do Parcel de Manuel Luiz & MA & $29 / 02 / 2000$ \\
\hline 4. Parque Nacional do Araguaia - Ilha do Bananal & TO & $04 / 10 / 1993$ \\
\hline 5. Parque Nacional da Lagoa do Peixe & RS & $24 / 05 / 1993$ \\
\hline 6. Parque Nacional do Pantanal Mato-Grossense & MT & $24 / 05 / 1993$ \\
\hline 7. Reserva de desenvolvimento Sustentável Mamirauá & AM & $04 / 10 / 1993$ \\
\hline 8. Reserva Particular do Patrimônio Natural SESC Pantanal & MT & $06 / 12 / 2002$ \\
\hline 9. Reserva Particular do Patrimônio Natural Fazenda Rio Negro & MS & $28 / 05 / 2009$ \\
\hline 10. Parque Nacional Marinho dos Abrolhos & BA & $02 / 02 / 2010$ \\
\hline 11. Parque Estadual do Rio Doce & MG & $26 / 02 / 2010$ \\
\hline 12. Parque Nacional do Cabo Orange & AP & $2 / 02 / 2013$ \\
\hline \hline
\end{tabular}

A introdução dessas zonas úmidas na Lista de Ramsar faculta ao país a obtenção de apoio

\footnotetext{
${ }^{4}$ Adaptado de Recomendação CNZU no 5, de 25 de junho de 2012. Disponível em: $<$ http://www.mma.gov.br/biodiversidade/biodiversidade-aquatica/zonas-umidas-convencao-deramsar/s\%C3\%ADtios-ramsar-brasileiros >. Acesso em: 22 nov. 2015.
} 
para o desenvolvimento de pesquisas, o acesso a fundos internacionais para o financiamento de projetos e a criação de um cenário favorável à cooperação internacional. São dois os tipos de apoio financeiro: o Fundo de Pequenas Subvenções (Ramsar Small Grants Fund. Disponível em: http://www.ramsar.org/. Acesso em 26 mai 2015) e o Fundo Zonas Úmidas para o Futuro (Wetlands for the Future Fund. Disponível em: http://www.ramsar.org/. Acesso em 26 mai 2015). Os benefícios não se restringem aos financeiros, mas também incluem os de assessoria técnica para o desenho de ações orientadas à proteção das zonas úmidas (MMA).

De acordo com o sítio na rede mundial de computadores sobre as zonas úmidas mantido pelo MMA, “o título de Sítio Ramsar confere às áreas úmidas prioridade na implementação de políticas governamentais e reconhecimento público, tanto por parte da sociedade nacional como por parte da comunidade internacional, o que contribui para fortalecer sua proteção".

Em contrapartida, o Brasil assumiu o compromisso de manter suas características ecológicas - os elementos da biodiversidade e os processos que os mantêm, além de promover a utilização dos recursos naturais das zonas úmidas de forma sustentável, com qualidade de vida aos habitantes. A utilização sustentável é considerada como sinônimo do conceito de Uso Racional da Convenção. Também deve priorizar sua consolidação diante de outras áreas protegidas, conforme previsto no Plano Estratégico Nacional de Áreas Protegidas (PNAP), aprovado pelo Decreto no $5.758 / 06$.

O relatório ${ }^{5}$ elaborado pelo Brasil para a COP 12, realizada em junho de 2015, faz uma descrição das ações que vêm sendo tomadas no último triênio em relação às áreas úmidas brasileiras. Entre as dificuldades para a aplicação dos Sítios Ramsar, o relatório cita a falta de articulação entre os setores sobre o tema das zonas úmidas. Entre as prioridades para a implantação, enaltece a elaboração do Inventário Nacional de Zonas Úmidas e a designação de novos Sítios Ramsar que garantam a representatividade dos vários tipos de zonas úmidas existentes no país. O relatório argumenta que a implementação do Inventário pode orientar a conservação das zonas úmidas, ainda que não listadas, por meio do zoneamento ecológico-econômico. O relatório cita que está em curso um processo de revisão do conceito de áreas úmidas e a definição de suas tipologias para fins de implementação da Convenção Ramsar.

Como critérios de identificação de zonas úmidas de importância internacional, somados aos estabelecidos pela Convenção de Ramsar, o Comitê Nacional de Zonas Úmidas - CNZU recomenda os constantes na Tabela 2 (Recomendação CNZU nº 5, de 25 de junho de 2012). Além da adoção dos critérios relacionados, a CNZU também registra que o Brasil considera as demandas espontâneas para criação de novos sítios Ramsar como uma forma importante de disseminação da

\footnotetext{
${ }^{5}$ Disponível em: http://www.cnrh.gov.br/index.php?option=com_content\&view=article\&id=23. Acesso: 26 mai
} 2015 . 


\section{Convenção.}

\section{Tabela 2 - Critérios para a proposição de Sítios Ramsar no território brasileiro.}

Para cada uma das Áreas Protegidas que possuem ambientes típicos de áreas úmidas, dá-se uma pontuação conforme critérios listados a seguir:

\begin{tabular}{|c|c|c|}
\hline Critério & Pontuação & Regras da pontuação \\
\hline Representação nos Biomas ${ }^{1}$ & 0 a 5 & $\begin{array}{l}\text { Subtrair de } 5 \text { o número correspondente à quantidade de } \\
\text { sítios Ramsar já existentes no Bioma em que a Área } \\
\text { Protegida está presente. }\end{array}$ \\
\hline $\begin{array}{l}\text { Representação nas Ecorregiões } \\
\text { Aquáticas de Águas Continentais }{ }^{2} \\
\text { e Ecorregiões Marinhas }{ }^{3}\end{array}$ & 0 a 5 & $\begin{array}{l}\text { Subtrair de } 5 \text { o número correspondente à quantidade de } \\
\text { sítios Ramsar já existentes na Ecorregião em que a } \\
\text { Área Protegida está presente. }\end{array}$ \\
\hline $\begin{array}{l}\text { Importância Biológica das Áreas } \\
\text { Prioritárias para Conservação, } \\
\text { Uso Sustentável e Repartição dos } \\
\text { Benefícios da Biodiversidade } \\
\text { Brasileira }^{4}\end{array}$ & 0 a 5 & $\begin{array}{l}5 \text { para área com Importância Extremamente Alta; } \\
3 \text { para área com Importância Muito Alta; } \\
1 \text { para área com Importância Alta; e } \\
0 \text { para área com Importância Insuficientemente } \\
\text { Conhecida. }\end{array}$ \\
\hline $\begin{array}{l}\text { Áreas Importantes para a } \\
\text { Conservação das Aves }{ }^{5} \\
\text { (Important Bird Areas) - IBAs }\end{array}$ & 0 a 5 & $\begin{array}{l}5 \text { para áreas em até } 1 \mathrm{~km} \text { das IBAS; } \\
3 \text { para áreas em até } 15 \mathrm{~km} \text { das IBAS; } \\
1 \text { para áreas em até } 50 \mathrm{~km} \text { das IBAS; e } \\
0 \text { para áreas a mais de } 50 \mathrm{~km} \text { das IBAS. }\end{array}$ \\
\hline Percentual de Área Úmida & 0 a 5 & $\begin{array}{l}5 \text { para áreas com mais de } 50 \% \text { de ambientes de áreas } \\
\text { úmidas; } \\
3 \text { para áreas com } 20 \text { a } 50 \% \text { de ambientes de áreas } \\
\text { úmidas; } \\
1 \text { para áreas com } 5 \text { a } 20 \% \text { de ambientes de áreas } \\
\text { úmidas; e } \\
0 \text { para áreas com menos de } 5 \% \text { de ambientes de áreas } \\
\text { úmidas. }\end{array}$ \\
\hline $\begin{array}{l}\text { Bacias hidrográficas (ottobacias } \\
\text { de } 4^{\mathrm{a}} \text { a } 6^{\mathrm{a}} \text { ordem) que contém } \\
\text { peixes com distribuição restrita }{ }^{6}- \\
\text { KBAs de peixes (áreas-chave para } \\
\text { a conservação da biodiversidade } \\
\text { de peixes) }\end{array}$ & 0 a 1 & $\begin{array}{l}0 \text { para áreas que não fazem interseção com nenhuma } \\
\text { bacia hidrográfica representativa de peixes com } \\
\text { distribuição restrita; } \\
1 \text { para áreas que fazem interseção com alguma bacia } \\
\text { hidrográfica representativa de peixes com distribuição } \\
\text { restrita. }\end{array}$ \\
\hline
\end{tabular}

Observação: As pontuações dos critérios são somadas para cada uma das Áreas Protegidas e o resultado deve ser traduzido em duas listas ordenadas conforme as pontuações recebidas, e de acordo com a localização em ambiente continental ou em ambiente de zona costeira e marinho (vide Anexo B).

1 Amazônia, Caatinga, Cerrado, Pantanal, Mata Atlântica, Pampa, e Zona Costeira e Marinha.

2 Ecorregiões Aquáticas Brasileiras apresentadas no Plano Nacional de Recursos Hídricos (Volume 1: Panorama e estado dos recursos hídricos do Brasil), aprovado pela Resolução CNRH n ${ }^{\circ} 58$, de 30 de janeiro de 2006. Disponível no sítio eletrônico: www.mma.gov.br

3 Spalding, M.D., Fox, H.E., Allen, G.R., Davidson, N., Ferda na, Z.A., Finlayson, M., Halpern, B.S., Martin, K.D., Mcmanus, E., Molnar, J., Recchia, C.A. \& Robertson, J. (2007) arine Ecoregions of the World: A Bioregionalization of Coastal and Shelf Areas. Vol. 57 No. 7 - BioScience c

4 Áreas Prioritárias para a Conservação, Utilização Sustentável e Repartição de Benefícios da Biodiversidade Brasileira reconhecidas pela Portaria Ministerial No 9, de 23/01/2007. Disponível no sítio eletrônico: www.mma.gov.br

5 Important Bird Areas - IBAs. BirdLife Internacional - http://www.birdlife.org/action/science/sites/

6 Nogueira C., Buckup P.A., Menezes N.A., Oyakawa O.T., Kasecker T.P., et al. (2010) RestrictedRange Fishes and the Conservation of Brazilian Freshwaters. PloS ONE 5(6): e11390.

doi:10.1371/journal.pone.0011390

Além da Convenção de Ramsar, a Convenção sobre a Diversidade Biológica do Rio, instituída em 1992, e o Tratado da Bacia do Prata, assinado em Brasília em 1969 também versam sobre o tema de áreas úmidas.

\subsubsection{Legislação Federal}

Os conceitos de nascentes, veredas e áreas úmidas encontram-se definidos na legislação 
florestal brasileira pela Lei 12.651/2012 (Brasil 2012). Nesta lei, as feições hídricas são individualizadas, com o notável objetivo de restringir e diferenciar os instrumentos de proteção entre elas. É o que acontece no tratamento distinto entre nascentes e olhos d'água e entre áreas úmidas e todas as suas classes (entre as quais, as veredas, as várzeas, as restingas, os manguezais, entre outros).

Neste tópico, apresentam-se as definições presentes na legislação federal brasileira, com breves comentários sobre os critérios de identificação. A discussão quanto ao impacto dessas definições na legislação em relação à proteção prevista, as fragilidades nos conceitos e os casos reais investigados no Ministério Público Feral constam no tópico 2.4.

\section{a) Nascentes}

O primeiro conceito legal de nascentes surgiu com o Decreto 24.643, de 10 de julho de 1934 (BRASIL 1934), que instituiu o Código de Águas. Segundo o decreto:

Art. 89. Consideram-se "nascentes" para os efeitos deste Código, as águas que surgem naturalmente ou por indústria humana, e correm dentro de um só prédio particular, e ainda que o transponham, quando elas não tenham sido abandonadas pelo proprietário do mesmo.

Art. 90. O dono do prédio onde houver alguma nascente, satisfeitas as necessidades de seu consumo, não pode impedir o curso natural das águas pelos prédios inferiores.

ART. 91. Se uma nascente emerge em um fosso que divide dois prédios, pertence a ambos.

Art. 92. Mediante indenização, os donos dos prédios inferiores, de acordo com as normas da servidão legal de escoamento, são obrigados a receber as águas das nascentes artificiais.

Parágrafo único. Nessa indenização, porém, será considerado o valor de qualquer benefício que os mesmos prédios possam auferir de tais águas.

Art. 93. Aplica-se as nascentes o disposto na primeira parte do art. 79.

Art. 94. O proprietário de uma nascente não pode desviar-lhe o curso quando da mesma se abasteça uma população.

Art. 95. A nascente de uma água será determinada pelo ponto em que ela começa a correr sobre o solo e não pela veia subterrânea que a alimenta.

Esse conceito foi revisto e, em muitos aspectos, superado ao longo dos anos. Essas definições e diretrizes de nascentes antrópicas desempenharam uma função compatível com a implementação inicial do gerenciamento de recursos hídricos no Brasil e com a aceleração do processo de urbanização. Com o tempo, a função ambiental das nascentes passou a ser considerada. Na Lei 4.771, de 15 de setembro de 1965, revogada pela Lei 12.651/2012, as nascentes passaram 
a ser protegidas por APP.

Conforme a Lei 12.651/2012 (Brasil 2012 a), Art. 3o, o conceito de nascente difere do conceito de olho d'água:

XVII - Nascente: afloramento natural do lençol freático que apresenta perenidade e dá início a um curso d'água.

XVIII - Olho d'água: afloramento natural do lençol freático, mesmo que intermitente.

Conforme se depreende, ambos os conceitos envolvem o afloramento de água subterrânea, ou seja, o critério que os define é hidrogeológico. O que os diferencia é o critério de temporalidade.

\section{b) Veredas}

Segundo a Lei 12.651/2012 (Brasil 2012 a), Art. 3º o conceito de vereda é fitofisionômico: XII - Vereda: fitofisionomia de savana, encontrada em solos hidromórficos, usualmente com a palmeira arbórea Mauritia flexuosa - buriti emergente, sem formar dossel, em meio a agrupamentos de espécies arbustivo-herbáceas.

O critério de "solo hidromórfico" parece assumir um caráter identificador da fitofisionomia. Acredita-se que a ênfase sobre a condição de hidromorfismo dos solos em áreas de vereda deve ser considerada como o critério mais relevante para a determinação das veredas, pelas funções de manutenção ecológica e de qualidade/disponibilidade da água que desempenha. A tipificação pode ser caracterizada pelo complexo vegetacional que a compõe, inclusive com a frequente ocorrência de buriti.

Em relação ao termo "usualmente", entende-se que a presença das palmáceas citadas é eventual, o que validaria a proteção de áreas úmidas de configurações semelhantes, inclusive com outros tipos de palmáceas na definição - a exemplo do açaizeiro. Por outro lado, ressalta-se que as condições de hidromorfismo abordadas na legislação parecem ser um requisito à ocorrência da citada vegetação.

\section{c) Áreas Úmidas}

O conceito de áreas úmidas conforme a Lei 12.651/2012 (Brasil 2012 a), Art. 3º, não é coincidente com a definição de zonas úmidas da Convenção de Ramsar. Aparentemente busca induzir à tomada da parte pelo todo, ou seja, de apenas uma classe de área úmida como todas as demais classes, ao citar especificamente os pantanais:

XXV - Áreas úmidas: pantanais e superfícies terrestres cobertas de forma periódica por águas, cobertas originalmente por florestas ou outras formas de vegetação adaptadas à inundação.

As outras classes de áreas úmidas como veredas, manguezais, apicuns, restingas, várzeas, 
olhos d'água e outros corpos d'água, inclusive reservatórios artificiais derivados de cursos de água naturais (como açudes), são definidas separadamente, com critérios específicos de identificação. De qualquer maneira, como critérios gerais do conceito de áreas úmidas, citam-se a periodicidade na cobertura da superfície por água, com vegetação adaptada à inundação. Subentende-se que essa definição não exclui as demais classes de áreas úmidas, mas não deixa claro a inter-relação entre os conceitos.

\subsection{APLICAÇÃO DOS CONCEITOS DE NASCENTES, VEREDAS E ÁREAS ÚMIDAS CONFORME A LEI}

A aplicação dos conceitos de nascentes, veredas e áreas úmidas é avaliada quanto a três pontos: a proteção prevista (tópico 2.4.1), as fragilidades nos conceitos legais (tópico 2.4.2) e os casos investigados pelo Ministério Público Federal (tópico 2.4.3). Esta discussão é fundamental para a avaliação das reais necessidades quanto ao refinamento conceitual das feições hídricas, diante das limitações jurídicas de sua aplicação e de suas consequentes implicações práticas e legais.

\subsubsection{Proteção Prevista}

A legislação federal quanto ao meio ambiente baseia-se na Constituição Federal (Brasil 1988). O texto do Capítulo VI, dedicado ao Meio Ambiente, enfoca o conceito de desenvolvimento sustentável e faz referência expressa a espaços territoriais especialmente protegidos:

Art. 225. Todos têm direito ao meio ambiente ecologicamente equilibrado, bem de uso comum do povo e essencial à sadia qualidade de vida, impondo-se ao Poder Público e à coletividade o dever de defendê-lo e preservá-lo para as presentes e futuras gerações. $\S 1^{\circ}$ - Para assegurar a efetividade desse direito, incumbe ao Poder Público: [...] III - definir, em todas as unidades da Federação, espaços territoriais e seus componentes a serem especialmente protegidos, sendo a alteração e a supressão permitidas somente através de lei, vedada qualquer utilização que comprometa a integridade dos atributos que justifiquem sua proteção. [sem grifo no original].

Nascentes, veredas e áreas úmidas têm diferentes instrumentos de proteção segundo a legislação federal brasileira. Um desses instrumentos de proteção é a legislação florestal. De acordo com a Lei 12.651, de 25 de maio de 2012, que substituiu o Código Florestal, nascentes, veredas e áreas úmidas são consideradas como três tipos de feições hidrológicas sujeitas à proteção distinta. A lei é mais restritiva no caso das nascentes, mas apenas quando elas são perenes. Veredas e áreas úmidas somente são sujeitas à proteção ambiental em alguns casos.

No entanto, há outros instrumentos de proteção. As políticas ${ }^{6}$ nacionais do Brasil quanto à

\footnotetext{
${ }^{6}$ Adaptado de "Políticas Nacionais de Meio Ambiente no Brasil - Conservação e Uso Racional de Áreas Úmidas. Disponível em: <http://www.mma.gov.br/estruturas/205/_arquivos/polticas_nacionais_de_meio _ambiente_no_brasil_205.pdf $>$. Acesso em 27 mai 2015.
} 
conservação de nascentes e zonas úmidas - que conceitualmente incluem as veredas podem ser abordadas quanto a um arcabouço legislativo diverso: Política Nacional de Meio Ambiente; Política Nacional de Áreas Protegidas; Política Nacional de Biodiversidade; Política Nacional de Educação Ambiental; Plano Nacional de Gerenciamento Costeiro; Política Nacional de Recursos Hídricos.

Os itens seguintes apresentam as linhas gerais abordadas no arcabouço legislativo quanto a nascentes, veredas e áreas úmidas, direta ou indiretamente.

\section{a) Lei Florestal}

A Lei 12.651/2012 prevê instrumentos variados de proteção das feições hídricas. Entre eles, destacam-se as Áreas de Preservação Permanente - APPs, conhecidas pelas restrições impostas ao uso alternativo do solo ao redor de algumas feições naturais. Não obstante, há outros instrumentos de proteção menos específicos, mas não menos importantes.

Um dos instrumentos favoráveis à conservação de nascentes e de áreas úmidas - com inclusão de corpos de águas com múltiplas funções ambientais, inclusive as veredas - é o zoneamento ecológico econômico - ZEE (Lei 12.651/2012, Art. 13). O ZEE tem o potencial de desempenhar o importante papel de orientar a definição das reservas legais nas propriedades, de acordo com critérios ambientais: áreas prioritárias para conservação da biodiversidade e dos recursos hídricos e os corredores ecológicos. As orientações para o estabelecimento de reservas legais são (Lei 12.651/2012, Art. 14):

Art. 14. A localização da área de Reserva Legal no imóvel rural deverá levar em consideração os seguintes estudos e critérios:

I - o plano de bacia hidrográfica;

II - o Zoneamento Ecológico-Econômico;

III - a formação de corredores ecológicos com outra Reserva Legal, com Área de Preservação Permanente, com Unidade de Conservação ou com outra área legalmente protegida;

IV - as áreas de maior importância para a conservação da biodiversidade; e $\mathrm{V}$ - as áreas de maior fragilidade ambiental.

Nas propriedades que mantiverem Reserva Legal, conservada e averbada em área superior aos percentuais exigidos, poderá ser instituída servidão ambiental sobre a área incidente. A servidão ambiental é outro instrumento de incentivo à proteção ambiental, que constitui o Programa de Apoio e Incentivo à Recuperação do Meio Ambiente (Lei 12.651/2012, Art. 41 a 50), com várias linhas de ação. Entre elas se destacam o pagamento ou incentivo a serviços ambientais com retribuição às atividades de conservação e melhoria dos ecossistemas, como por exemplo (Art. 41, I):

a) o sequestro, a conservação, a manutenção e o aumento do estoque e a 
diminuição do fluxo de carbono;

b) a conservação da beleza cênica natural;

c) a conservação da biodiversidade;

d) a conservação das águas e dos serviços hídricos;

e) a regulação do clima;

f) a valorização cultural e do conhecimento tradicional ecossistêmico;

g) a conservação e o melhoramento do solo;

h) a manutenção de Áreas de Preservação Permanente, de Reserva Legal e de uso restrito.

A compensação pelas medidas de conservação ambiental tem várias vantagens como a obtenção de crédito agrícola com taxas de juros menores, condições melhores para seguro agrícola; dedução de APPs e de Reserva Legal da base de cálculo do Imposto sobre a Propriedade Territorial, com créditos tributários, linhas de financiamento para iniciativas de preservação voluntária e isenção de impostos para insumos e equipamentos (Lei 12.651/12, Art. 41). Além disso, há previsão específica para recursos hídricos, com destinação de parte dos recursos arrecadados com a cobrança pelo uso da água, na forma da Lei 9.433/1997 para a manutenção, recuperação ou recomposição das APPs, de Reserva Legal e de uso restrito na bacia de geração da receita.

Também há previsão de incentivos para comercialização, inovação e aceleração das ações de recuperação, conservação e uso sustentável das florestas e demais formas de vegetação nativa com a participação preferencial nos programas de apoio à comercialização do produto agrícola; destinação de recursos para a pesquisa científica e tecnológica e a extensão rural relacionadas à melhoria da qualidade ambiental; dedução do imposto de renda de pessoa física ou jurídica de parte dos gastos efetuadas com recomposição de APP, de Reserva Legal e de uso restrito com desmatamento anterior a 22 de julho de 2008 e utilização de fundos públicos para concessão de créditos reembolsáveis e não reembolsáveis destinados a estas áreas. Empresas que industrializem ou que comercializem produtos de propriedades ou posses rurais que cumprem ou que estão em processo de cumprir os padrões e limites estabelecidos em relação a APPs (Lei 12.651/2012, Art. $4^{\circ}$ e $6^{\circ}$ ), a atividades em áreas de inclinação entre 25 e $45^{\circ}$ e a Reserva Legal, poderão usufruir de diferenciação tributária (Lei 12.651/2012, Art. 41, § $2^{\circ}$ ). O pagamento por esses serviços ambientais configura adicionalidade para mercados e nacionais e internacionais de reduções de emissões.

Para o pagamento por serviços ambientais, há a Cota de Reserva Ambiental - CRA, título que representa a área com vegetação nativa, existente ou em processo de recuperação (Lei 12.651/12, Art. 44). Para a servidão ambiental, a CRA é instituída com base no Art. $9^{\circ}$-A da Lei 6.938, de 31 de agosto de 1981. Cada CRA corresponde a um hectare (Lei 12.651/12, Art. 46) de área de revegetação nativa primária ou secundária em qualquer estágio de regeneração ou recomposição ou de áreas de recomposição mediante reflorestamento com espécies nativas. A 
CRA pode compensar Reserva Legal, desde que respeitados os requisitos no $\S 6^{\circ}$ do Art. 66 (Lei 12.651/12) e dentro do mesmo bioma. Na CRA é necessária a conservação da vegetação nativa que deu origem ao título.

Esses instrumentos de incentivo à conservação e recuperação florestal, que podem ser direcionados à proteção de feições hídricas, previstos na Lei 12.651/2012 se somam aos das APPs. O estabelecimento de APP é específico para cada tipo de feição previsto na legislação florestal, com níveis variados de abrangência e proteção. Elas são instituídas nas margens de certas feições relacionadas na lei 12.651/2012 e nelas não pode haver supressão de vegetação. Algumas relativizações da proteção prevista que envolvem APPs são relacionadas ao baixo impacto ambiental, pequenas propriedades ou posses rurais familiares, comunidades tradicionais e povos indígenas. Além disso, pessoas e animais podem acessar as Áreas de Preservação Permanente para obtenção de água (Lei 12.651, Art. $9^{\circ}$ ).

No caso de áreas com uso consolidado antes de 22 de julho de 2008, há previsão de continuidade das atividades agrossilvipastoris, de ecoturismo ou de turismo rural com recomposição parcial da vegetação das APPs. A faixa de recomposição varia de acordo com a feição protegida e com o tamanho da propriedade ou posse rural. É vedada a conversão de novas áreas para uso alternativo do solo.

Algumas medidas mais restritivas em relação ao estabelecimento de APPs podem ser tomadas no caso de bacias hidrográficas consideradas críticas, com imposição de conservação da vegetação nativa superior à definida na legislação, de acordo com a seguinte previsão do Art. 61A:

$\S$ 17. Em bacias hidrográficas consideradas críticas, conforme previsto em legislação específica, o Chefe do Poder Executivo poderá, em ato próprio, estabelecer metas e diretrizes de recuperação ou conservação da vegetação nativa superiores às definidas no caput e nos $\S \S 1^{\circ}$ a $7^{\circ}$, como projeto prioritário, ouvidos o Comitê de Bacia Hidrográfica e o Conselho Estadual de Meio Ambiente. (Incluído pela Lei no 12.727, de 2012).

A função ambiental das APPs é a preservação dos recursos hídricos, da paisagem, da estabilidade geológica e da biodiversidade, facilitação do fluxo gênico de fauna e flora, proteção do solo e a garantia do bem-estar das populações humanas. No caso de nascentes, veredas e áreas úmidas, há a previsão de estabelecimento de APPs de maneira diferenciada, conforme se segue:

\section{Nascentes}

Áreas de Preservação Permanente - APP, em zonas rurais ou urbanas, para os efeitos legais são consideradas (Lei 12.651, Art. $4^{\circ}, \mathrm{IV}$, incluído pela Lei $\mathrm{n}^{\circ}$ 12.727, de 2012, e Art. $8^{\circ}$ ): 
IV - as áreas no entorno das nascentes e dos olhos d'água perenes, qualquer que seja sua situação topográfica, no raio mínimo de 50 (cinquenta) metros (Redação dada pela Lei $\mathrm{n}^{\circ}$ 12.727, de 2012).

$[\ldots]$

$\S 1$ A supressão de vegetação nativa protetora de nascentes, dunas e restingas somente poderá ser autorizada em caso de utilidade pública. [sem grifo no original]

Consideram-se de utilidade pública as atividades apresentadas na Tabela 3.

Tabela 3 - Atividades de Utilidade Pública.

\section{Atividades de Utilidade Pública com base na Lei 12.651/12 (Art. 3, VIII)}

a) as atividades de segurança nacional e proteção sanitária

b) as obras de infraestrutura destinadas às concessões e aos serviços públicos de transporte, sistema viário, inclusive o necessário aos parcelamentos de solo urbano aprovados pelos municípios, saneamento, gestão de resíduos, energia, telecomunicações, radiodifusão, instalações necessárias à realização de competições esportivas estaduais, nacionais ou internacionais e de mineração, exceto, neste último caso, a extração de areia, argila, saibro e cascalho.

c) atividades e obras de defesa civil.

d) atividades que comprovadamente proporcionem melhorias na proteção das funções ambientais relativas a APPs.

e) outras atividades similares devidamente caracterizadas e motivadas em procedimento administrativo próprio, quando inexistir alternativa técnica e locacional ao empreendimento proposto, definidas em ato do Chefe do Poder Executivo Federal.

Além disso, a Lei Florestal prevê a recomposição de APPs no caso de áreas rurais consolidadas. No entanto, a recomposição é apenas parcial (Art. 61-A):

§ 5 Nos casos de áreas rurais consolidadas em Áreas de Preservação Permanente no entorno de nascentes e olhos d'água perenes, será admitida a manutenção de atividades agrossilvipastoris, de ecoturismo ou de turismo rural, sendo obrigatória a recomposição do raio mínimo de 15 (quinze) metros.

\section{Veredas}

As APPs de vereda ocorrem em dois casos:

Art. $4^{\circ}$ Consideram-se Áreas de Preservação Permanente - APP:

XI - em veredas, a faixa marginal, em projeção horizontal, com largura mínima de 50 (cinquenta) metros, a partir do espaço permanentemente brejoso e encharcado (Redação dada pela Lei no 12.727 , de 2012).

$[\ldots]$ 
Art. 6 Consideram-se, ainda, de preservação permanente, quando declaradas de interesse social por ato do Chefe do Poder Executivo, as áreas cobertas com florestas ou outras formas de vegetação destinadas a uma ou mais das seguintes finalidades:

II - proteger as restingas ou veredas;

III - proteger várzeas; [sem grifo no original]

O interesse social é considerado pela Lei 12.651/2012 sendo apresentadas na Tabela 4 a principais condicionantes de uso para enquadramento.

Tabela 4 - Interesse Social.

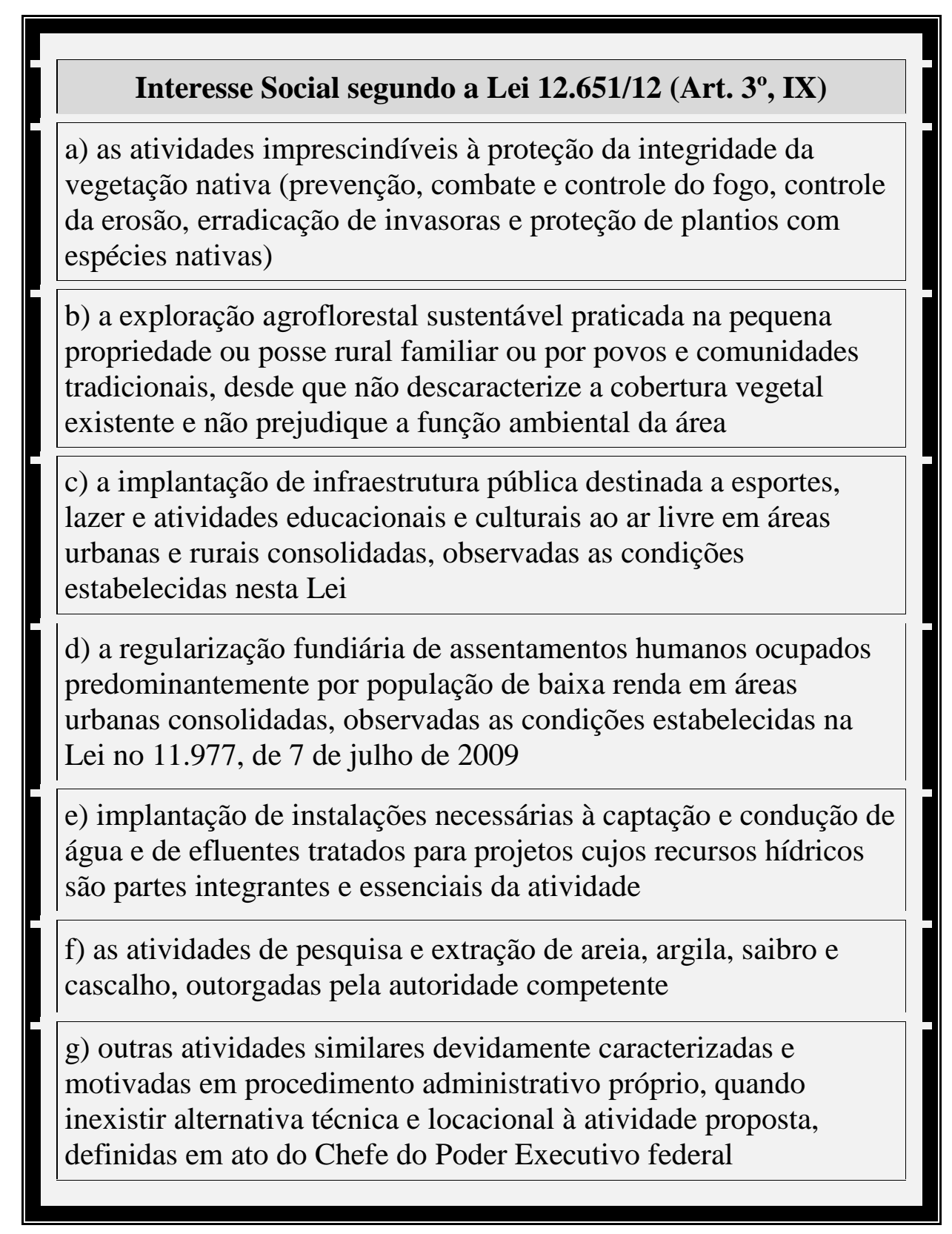

Em APP, autoriza-se a continuidade das atividades agrossilvipastoris, de ecoturismo e de turismo rural, desde que consolidadas até julho de 2008 (Lei 12.651/2012, Art. 61-A). No entanto, as APPs devem ser recuperadas parcialmente. No caso das veredas, a recomposição deve ser feita da seguinte maneira: 
$\S 7$ Nos casos de áreas rurais consolidadas em veredas, será obrigatória a recomposição das faixas marginais, em projeção horizontal, delimitadas a partir do espaço brejoso e encharcado, de largura mínima de:

I - 30 (trinta) metros, para imóveis rurais com área de até 4 (quatro) módulos fiscais; e

II - 50 (cinquenta) metros, para imóveis rurais com área superior a 4 (quatro) módulos fiscais.

\section{Áreas Úmidas}

As áreas úmidas que não são referidas de maneira individualizada por classes específicas na Lei 12.651/2012 podem ser consideradas Áreas de Preservação Permanente - APP, desde que declaradas de interesse social pelo Chefe do Poder Executivo. A seguir citam-se as previsões de proteção mais diretamente relacionadas à definição generalista de áreas úmidas, em função das condições da cobertura periódica por água:

Art. 6 Consideram-se, ainda, de preservação permanente, quando declaradas de interesse social por ato do Chefe do Poder Executivo, as áreas cobertas com florestas ou outras formas de vegetação destinadas a uma ou mais das seguintes finalidades:

(...)

IX - proteger áreas úmidas, especialmente as de importância internacional. [sem grifo no original]

Subentende-se que a proteção prevista no inciso IX busca coadunar com a Convenção de Ramsar. A previsão é estratégica, se utilizada com o devido potencial de proteger áreas úmidas a partir da elaboração de um inventário brasileiro de zonas úmidas. De fato, as áreas úmidas de importância internacional - denominadas de sítios Ramsar, quando reconhecidas oficialmente pressupõem proteção elevada prévia, por instituição de Unidade de Conservação - UC. Ainda assim, fora das UCs, áreas adicionais podem ser declaradas de interesse social como APP, cuja vegetação se destine à finalidade de proteção de áreas úmidas.

Além disso, o artigo $6^{\circ}$ da Lei 12.651/2012 não reserva exclusivamente às áreas úmidas de importância internacional a declaração de interesse para a sua proteção por APP. Dessa forma, o Inventário de Zonas Úmidas previsto pela Convenção de Ramsar para cada país signatário pode ser o instrumento base para a determinação e o estabelecimento de APPs em zonas úmidas, ainda que não se enquadrem como de importância internacional.

A classe de áreas úmidas relacionada a pantanais e planícies pantaneiras é considerada de uso restrito e o seu uso é condicionado ao seguinte procedimento (Lei 12.651/2012, Art. 10):

Nos pantanais e planícies pantaneiras, é permitida a exploração ecologicamente sustentável, devendo-se considerar as recomendações técnicas dos órgãos oficiais de pesquisa, ficando novas supressões de vegetação nativa para uso alternativo do solo condicionadas à autorização do órgão estadual do meio ambiente, com base 
nas recomendações mencionadas neste artigo.

Outras classes de áreas úmidas discriminadas de forma individualizada na Lei 12.651/2012 e/ou eventualmente não inseridas nas previsões de proteção específicas podem ser incluídas como APP, caso declaradas de interesse social conforme as diretrizes a serem obtidas a partir do Inventário de Zonas Úmidas. Entre as classes de áreas úmidas não incluídas nas previsões de proteção específicas que poderiam passar a ser protegidas a partir do Inventário de Zonas Úmidas citam-se algumas classes de solos com condições de hidromorfismo, conforme a sua relevância em termos de funções ambientais, e outros corpos de água decorrentes de contextos naturais, como meandros abandonados e olhos d'água.

Vale citar que corpos de água que não decorram de cursos d'água naturais não são passíveis de proteção por meio do estabelecimento de APP (Lei 12.651/2012, Art. $4^{\circ}$ ) - o que é uma condição razoável, por excluir reservatórios decorrentes de obras de urbanismo (como piscinas, rede de esgotos e de drenagem pública):

$\S 1^{\circ}$ Não será exigida Área de Preservação Permanente no entorno de reservatórios artificiais de água que não decorram de barramento ou represamento de cursos d'água naturais.

\section{b) Política Nacional do Meio Ambiente}

A Política Nacional do Meio Ambiente - PNMA, estabelecida pela Lei 6.938, de 31 de agosto de 1981 (Brasil 1981), dispõe sobre diretrizes que orientam o desenvolvimento socioeconômico alinhado à melhoria e recuperação da qualidade ambiental. Um dos princípios da PNMA é a racionalização do uso do solo, do subsolo, da água e do ar (Art. $2^{\circ}$, II), considerados como recursos ambientais (Art. $3^{\circ}$ ). Com esta finalidade, PNMA objetiva a definição de áreas prioritárias de ação governamental relativa à qualidade e ao equilíbrio ecológico, atendendo aos interesses dos entes federativos (Art. $4^{\circ}$, II).

A legislação florestal brasileira acrescentou à Lei 6.938/1981 o detalhamento de instrumentos de conservação de áreas prioritárias. Eles estabelecem incentivos para a limitação total ou parcial de propriedades para preservar, conservar ou recuperar os recursos ambientais existentes, com a instituição da servidão ambiental (Art. 9 -A). Com a Lei 12.651/2012 a PNMA passa a incorporar o detalhamento de regras, limitações e benefícios da servidão ambiental. As áreas prioritárias para a conservação de feições hídricas como nascentes e áreas úmidas em geral têm como respaldo estas previsões.

A servidão ambiental não se aplica às APPs e à Reserva Legal mínima exigida (Art. $9^{\circ}$-A, $\S 2$ ). Assim, possibilita a garantia da conservação de feições com funções ambientais relevantes, não contempladas pela obrigatoriedade, mas por vantagens de cunho econômico, social e 
ambiental. A restrição de uso e exploração de área sob servidão ambiental não é máxima, mas no mínimo, a estabelecida para a Reserva Legal (Art. $9^{\circ}-\mathrm{A}, \S 3$ ). Durante o prazo de vigência da servidão ambiental não é possível a alteração da destinação da área (Art. $9^{\circ}$-A, $\S 6$ ). O prazo mínimo da servidão ambiental temporária é de quinze anos (Art. $9^{\circ}$-B, $\S 1$ ).

A servidão ambiental tem o potencial de ser um instrumento vantajoso de conservação ou recuperação de feições hídricas, pelos incentivos fiscais, financeiros e ambientais que oferece aos proprietários de terra que a estabelecem. Integrada a outros instrumentos da PNMA, como o zoneamento ecológico-econômico (ao qual o inventário de áreas úmidas deve embasar e compor), pode garantir a proteção de feições hídricas não abrangidas pelas APPs, a exemplo de olhos d'água e áreas úmidas não listadas como de importância internacional.

\section{c) Plano Estratégico Nacional de Áreas Protegidas}

O Plano Estratégico Nacional de Áreas Protegidas - PNAP, instituído pelo Decreto $\mathrm{n}^{\circ}$ 5.758, de 13 de abril de 2006 (Brasil 2006), aborda mais diretamente a questão das áreas úmidas. Entre as diretrizes, a PNAP incorpora a noção de que as áreas protegidas devem ser apoiadas por sistema de práticas de manejo sustentável dos recursos naturais, integrado com a gestão das bacias hidrográficas (1.2 Diretrizes, VI).

Como estratégias, prevê a avaliação das principais áreas de recarga de aquífero para inclusão no planejamento para ampliação do SNUC (II - Estratégias, b); a proposição e implementação de ações e instrumentos para a integração do PNAP com o Plano Nacional de Recursos Hídricos - PNRH (II - Estratégias, j); o estabelecimento de mecanismos para utilização da compensação de passivos de Reserva Legal em propriedades rurais na ampliação e criação de unidades de conservação (II - Estratégias, m); estabelecimento de agenda de entendimentos com os setores governamentais, nas três esferas de governo, com o objetivo de harmonizar os sistemas federal, estadual e municipal de unidades de conservação, nos diversos ordenamentos territoriais setoriais II - Estratégias, $n$ ).

Entre os objetivos gerais, cita a integração das unidades de conservação a paisagens terrestres e marinhas mais amplas, de modo a manter a sua estrutura e função ecológicas e socioculturais. Com isto, vincula a proposição e implementação de ações de integração e articulação entre os instrumentos de conectividade e as unidades de conservação e demais áreas protegidas, com destaque para as zonas úmidas (Objetivo Geral 3.3, estratégia h).

O impedimento de ameaças e a mitigação dos impactos negativos aos quais as unidades de conservação e suas zonas de amortecimento estejam expostos também figura entre os objetivos gerais (Objetivo-Geral 3.5). Entre as estratégias, consta a promoção da gestão integrada de recursos florestais e hídricos, especialmente por meio da interação dos órgãos gestores de florestas 
com os órgãos e entidades do Sistema Nacional de Gerenciamento de Recursos Hídricos (estratégia e).

O PNAP apresenta estratégias nacionais específicas para as áreas com reconhecimento internacional. Como objetivo geral, visa implementar convenções, tratados e programas intergovernamentais, relacionados às áreas naturais protegidas, dos quais o Brasil é parte (Objetivo Geral 8). Nesta temática, introduz como objetivos específicos o estabelecimento de gestão integrada das áreas de reconhecimento internacional situadas no território nacional (Objetivo Específico d) e de uma política nacional para as zonas úmidas, no escopo da Convenção de Ramsar. Com essas intenções, prevê como estratégias o estabelecimento de acordos e parcerias que favoreçam a implementação das Convenções do Patrimônio Mundial e de Ramsar, do Tratado de Cooperação Amazônica e do Programa "O Homem e a Biosfera" da Unesco, no Brasil (Estratégia a); priorização das áreas de reconhecimento internacional na implementação e consolidação das unidades de conservação (Estratégia b); seleção de novas áreas nacionais que atendam aos critérios para reconhecimento internacional pelas convenções (Estratégia c); realização de troca de informações e experiências entre os países signatários das Convenções do Patrimônio Mundial e de Ramsar, do Tratado de Cooperação Amazônica e do Programa "O Homem e a Biosfera" da Unesco (Estratégia h); capacitação de técnicos e gestores para o aproveitamento das vantagens e cumprimento das obrigações dos tratados e programas intergovernamentais relacionados às áreas protegidas dos quais o Brasil é parte (Estratégia i); realização de diagnóstico e classificação das zonas úmidas brasileiras, relacionando as características das áreas aos critérios necessários ao reconhecimento internacional pela Convenção de Ramsar (Estratégia j); e formulação de proposta de política nacional para as zonas úmidas (Estratégia 1).

\section{d) Política Nacional da Biodiversidade}

A Política Nacional da Biodiversidade - PNBio foi instituída pelo Decreto 4.339, de 22 de agosto de 2002 (Brasil 2002). Entre as diretrizes relacionadas direta ou indiretamente às nascentes e às áreas úmidas, estabelece a cooperação com outras nações quanto a espécies migratórias - o que remete à Convenção de Ramsar, entre outros assuntos transfronteiriços e de mútuo interesse (Diretriz I).

Além disso, traça como objetivos específicos o apoio a ações de zoneamento e identificação de áreas críticas, por bacias hidrográficas, para conservação da biodiversidade e dos recursos hídricos (Objetivo Específico 13.2.16); o apoio a estudos de impacto sobre a biodiversidade nas diferentes bacias hidrográficas e a promoção da recuperação, revitalização e conservação da biodiversidade, sobretudo nas matas ribeirinhas, cabeceiras, olhos d'água e outras áreas de 
preservação permanente e em áreas críticas para a conservação de recursos hídricos (Objetivos Específicos 13.3.11 e 13.3.13).

\section{e) Política Nacional de Gerenciamento Costeiro}

O Plano Nacional de Gerenciamento Costeiro - PNGC, instituído pela Lei 7.661, de 16 de maio de 1988 (Brasil 1988 b), tem estrita relação com a proteção de áreas úmidas - especificamente com as costeiras e marinhas. O Art. $3^{\circ}$ explicita várias classes de áreas úmidas de ambientes costeiros:

Art. $3^{\circ}$. O PNGC deverá prever o zoneamento de usos e atividades na Zona Costeira e dar prioridade à conservação e proteção, entre outros, dos seguintes bens:

I - recursos naturais, renováveis e não renováveis; recifes, parcéis e bancos de algas; ilhas costeiras e oceânicas; sistemas fluviais, estuarinos e lagunares, baías e enseadas; praias; promontórios, costões e grutas marinhas; restingas e dunas; florestas litorâneas, manguezais e pradarias submersas;

II - sítios ecológicos de relevância cultural e demais unidades naturais de preservação permanente;

III - monumentos que integrem o patrimônio natural, histórico, paleontológico, espeleológico, arqueológico, étnico, cultural e paisagístico.

A citação de "sítios ecológicos de relevância cultural" chama a atenção para o papel que zonas úmidas podem desempenhar sob o ponto de vista social, com diferentes manifestações culturais, por vezes tradicionais, relacionadas à pesca, aquicultura e outras atividades vinculadas a feições hídricas costeiras ou oceânicas.

Além disso, relaciona-se de maneira direta com o patrimônio hidrogeológico (incluído no patrimônio natural, supracitado no Art. $3^{\circ}$, III), com reflexões sobre a necessidade de geoconservação de algumas feições com características relevantes do ponto de vista científico por meio do instrumento do zoneamento de monumentos dos sítios de grande relevância científica (ou seja, de geossítios).

\section{f) Política Nacional da Educação Ambiental}

A Política Nacional da Educação Ambiental - PNEA, instituída pela Lei 9.795, de 17 de abril de 1999 (Brasil 1999), toma por base a divulgação e conscientização sobre os conceitos e orientações para a conservação ambiental. A conservação de feições hídricas como nascentes e os diversos tipos de áreas úmidas requerem o processo de construção de valores sociais, conhecimentos, habilidades, atitudes e competências (previstos pelo Art. $1^{\circ}$ da PNEA), com base 
na concepção do meio ambiente em sua totalidade e na interdependência entre o meio natural, o socioeconômico e o cultural, sob o enfoque da sustentabilidade (Art. $4^{\mathrm{o}}$, II).

\section{g) Política Nacional dos Recursos Hídricos}

A Política Nacional dos Recursos Hídricos - PNRH foi instituída pela Lei 9.433, de 8 de janeiro de 1997 (Brasil 1997). A proteção de nascentes e áreas úmidas não é mencionada diretamente, mas é abrangida indiretamente pelas diretrizes gerais de ação (Art. $3^{\circ}$, V), que preveem a articulação da gestão de recursos hídricos com a do uso do solo. Isto sugere que a gestão do uso do solo, orientada por zoneamento de atividades, considere a gestão adequada dos recursos hídricos.

A integração da gestão do uso dos solos com a gestão de recursos hídricos também pode ser avaliada quanto à uma interface específica - e pouco abordada na legislação - entre esses recursos ambientais: a de solos com condições de hidromorfismo. São diversas as classes de solos ditos, genericamente, como hidromórficos. Algumas dessas classes certamente desempenham importantes funções ambientais relativas à disponibilidade hídrica e devem ser protegidas. A PNRH tem previsões específicas quanto ao diagnóstico da situação dos recursos hídricos por meio dos Planos de Recursos Hídricos (Art. $7^{\circ}$, I), elaborados por bacia hidrográfica (Art. $8^{\circ}$ ), e quanto à análise de alternativas de crescimento demográfico, de evolução de atividades produtivas e de modificações dos padrões de ocupação do solo (Art. $7^{\circ}$, II). A partir da análise prevê a possibilidade de propostas para a criação de áreas sujeitas a restrição de uso, com vistas à proteção dos recursos hídricos (Art. $\left.7^{\circ}, \mathrm{X}\right)$.

A PNRH institui instrumentos como a outorga dos direitos de uso de recursos hídricos e o Sistema de Informações sobre Recursos Hídricos - SIRH (Art. 5ª III e VI). A outorga favorece o uso sustentável da água, por limitar volumes a serem extraídos em um determinado tempo estabelecido e por instituir a cobrança por seu uso, quando indicado. Já o SIRH consiste em ferramenta de gestão que pode orientar o uso racional dos recursos hídricos, de maneira integrada - com base em informações sobre águas superficiais, subterrâneas e índices pluviométricos.

Quanto à óptica ambiental na gestão de recursos hídricos, a PNRH considera ainda que:

Art. 30. Na implementação da Política Nacional de Recursos Hídricos, cabe aos

Poderes Executivos Estaduais e do Distrito Federal, na sua esfera de competência:

IV - promover a integração da gestão de recursos hídricos com a gestão ambiental.

Por fim, registra-se que a PNRH substituiu em grande parte as disposições do Antigo Código de Águas de 1934, inclusive quanto às nascentes - consideradas como sujeitas ao aproveitamento das águas particulares antes da Constituição Federal de 1988, que passou a estabelecer que todas as águas são públicas. 


\subsubsection{Fragilidades nos Conceitos Legais}

\section{a) Nascentes}

A conceituação legal de nascentes não é satisfatória para todas as situações. A principal fragilidade é a falta do critério temporal para a sua definição. Ou seja, não há clareza quanto aos parâmetros de perenidade, sazonalidade e efemeridade.

Em configurações específicas, como no semiárido, as surgências de água sazonais denominadas como olhos d'água pela legislação florestal possivelmente desempenham funções ambientais importantes e devem ser protegidas para a manutenção da qualidade e da disponibilidade de água no sistema hídrico, ainda que não sejam consideradas legalmente como nascentes pelo critério de perenidade.

Além disso, o critério de perenidade das nascentes não é consistente com o de proteção dos cursos d'água, que não requer perenidade. Os cursos d'água intermitentes também são protegidos, com exceção dos efêmeros (Lei 12.651, Art. $4^{\circ}$ ):

I - as faixas marginais de qualquer curso d'água natural perene e intermitente, excluídos os efêmeros, desde a borda da calha do leito regular, em largura mínima de:

a) 30 (trinta) metros, para os cursos d'água de menos de 10 (dez) metros de largura;

b) 50 (cinquenta) metros, para os cursos d'água que tenham de 10 (dez) a 50 (cinquenta) metros de largura;

c) 100 (cem) metros, para os cursos d'água que tenham de 50 (cinquenta) a 200 (duzentos) metros de largura;

d) 200 (duzentos) metros, para os cursos d'água que tenham de 200 (duzentos) a 600 (seiscentos) metros de largura;

e) 500 (quinhentos) metros, para os cursos d'água que tenham largura superior a 600 (seiscentos) metros. [sem grifo no original]

A legislação tornou a proteção de nascentes menos restritiva com a superveniência da Lei 12.651/12. Olhos d'água que não são perenes deixaram de ter faixa de APP ao seu redor. De qualquer maneira, olhos d'água também são considerados como zonas úmidas, conforme o conceito estabelecido pela Convenção de Ramsar. Portanto, o estabelecimento de um inventário nacional de zonas úmidas, com adequada escala e abrangência das áreas úmidas de pequenas dimensões, integrado ao zoneamento ecológico-econômico poderia cumprir o papel de proteção de olhos d'água nas mais diversas configurações, inclusive em áreas críticas como no semiárido.

Além disso, nota-se que a integração entre os diferentes instrumentos legais e políticas nacionais relacionados ao meio ambiente não são amplamente empregados em seu potencial. O fato é que as APPs não são o único instrumento de proteção às feições hídricas. O zoneamento 
ecológico-econômico, aliado à servidão ambiental e à restrição de uso para a proteção de recursos hídricos podem ser eficientes maneiras de abranger áreas relevantes de olhos d'água e de nascentes não perenes. Portanto, para que haja o devido emprego desses instrumentos é necessária a gestão dos recursos hídricos, balizada pela educação ambiental e conscientização.

\section{b) Veredas}

A conceituação legal de veredas constante na Lei 12.651/12 não deixa clara a sua designação como uma classe de área úmida, apesar de encaixar-se entre as classes de corpos d'água considerados pela Convenção de Ramsar, da qual o Brasil é signatário (CPP \& INAU 2012).

Além disso, a proteção prevista na Legislação Florestal não é consistente com o conceito de veredas pela própria Lei 12.651/2012. A proteção da vereda por APP em sua faixa marginal, com largura mínima de cinquenta metros a partir do espaço permanentemente brejoso, implica que a fitofisionomia de savana que a define não necessariamente será completamente protegida, o que é uma incongruência de definição. A inversão de elementos identificadores e caracterizadores na definição de veredas não parece tão favorável na conceituação dessas feições hídricas. Veredas não são compostas apenas por buritizais, mas abrangem complexo vegetacional.

Por fim, ressalta-se que a principal fragilidade no conceito legal de vereda é a inversão do critério de identificação (solos com elevado grau de hidromorfismo) com o critério de caracterização (fitofisionomia). Sem essa clareza, a proteção das veredas se restringe a uma configuração muito específica que desconsidera o complexo vegetacional da própria vereda e o seu caráter transicional com outras fitofisionomias com o crescente encaixe do talvegue (como brejos, matas alagadas, matas de galeria, matas ciliares). Não obstante, há outras configurações semelhantes tão ricas em funções ecossistêmicas e ambientais quanto as veredas que são desprotegidas por APP segundo a definição da lei, como buritizais, carnaubais, açaizais e diversas outras categorias de AUs, simplesmente por apresentarem variações fitofisionômicas (critério tipificador).

\section{c) Áreas Úmidas}

O conceito legal de áreas úmidas não é o mesmo que o da Convenção de Ramsar. Ainda que o conceito não exclua as previsões do tratado internacional do qual o Brasil é signatário, não é claro quanto a inter-relação com classes específicas de áreas úmidas além dos pantanais - como veredas, olhos d'água, restingas, apicuns, manguezais, entre outros corpos d'água. Ou seja, a principal fragilidade conceitual de áreas úmidas é a imprecisão quanto à grande abrangência do termo. 
A questão das condições de hidromorfismo dos solos, critério identificador para algumas das classes de áreas úmidas, também não é abordada - de maneira que a proteção necessária dessas áreas úmidas não é claramente considerada.

O inventário de áreas úmidas ainda não está implementado no país. Este fato limita e inclusive inviabiliza a criação de APPs a partir de um gerenciamento estratégico bem formulado.

\subsubsection{Casos Investigados pelo Ministério Público Federal}

Questões controversas sobre feições hídricas frequentemente geram demandas de investigação pelo Ministério Público sobre a pertinência de implementação de medidas de prevenção. As discussões muitas vezes passam pelo âmbito de conceitos, determinação e caracterização das feições hídricas, como nos exemplos citados a seguir:

\section{a) Nascentes}

- Nascentes antrópicas. Contexto: existência de surgências de água no sopé de encosta, criadas pela atividade de pedreira desativada há muitos anos, enquanto na parte superior há ocupação urbana. Os afloramentos de água surgiram em resposta à alteração da topografia decorrente do processo de lavra. Parte de via pública e alguns lotes e construções estão na borda da cava (topo da encosta) e a distância entre eles e o afloramento da superfície potenciométrica é inferior a cinquenta metros. Questão: seria cabível a delimitação de APP? Parecer (adaptado): “As normas legais pertinentes eram na época o Código Florestal e a Resolução Conama $n^{\circ}$ 303/2002. O primeiro determinava em seu artigo $2^{\circ}$, alínea “c" que as áreas ao redor de nascentes, ainda que intermitentes, em um raio mínimo de 50 metros, fossem preservadas permanentemente, enquanto o segundo, que dispunha sobre parâmetros, definições e limites de Áreas de Preservação Permanente, conceituava nascente como "local onde aflora naturalmente, mesmo que de forma intermitente, a água subterrânea". As nascentes artificiais, como as do fundo da cava da pedreira em tela, não se enquadram em tal definição e não devem ser consideradas para efeito de delimitação de APP. Tal entendimento é suportado no fato de que a água só aflora neste local em decorrência do rebaixamento do terreno causado pelo homem, e não naturalmente, como preconiza a Resolução Conama n 303/2002. O termo "naturalmente" implica na ausência de interferência humana, decorrente principalmente do fato de que as nascentes "não artificiais" ocorrem na natureza como resultado de processos físicos em uma escala de tempo geológica. Já a interpretação controversa de que uma nascente artificial seria compatível com a definição apresentada pela Resolução Conama 303/2002, desde que a água surgisse sem necessidade de bombeamento, implicaria em estender o status de APP à situações incompatíveis com seus objetivos, como por 
exemplo: i) minas (a céu aberto e subterrânea), que comumente possuem surgências de água, decorrente do rebaixamento da topografia; ii) escavações para a construção da fundação de edifícios e outras obras, que não raro alcançam a superfície potenciométrica do aquífero, provocando o aparecimento de nascentes artificiais; iii) cisternas escavadas e poços tubulares jorrantes, que nada mais são do que o rebaixamento da superfície topográfica com o objetivo de gerar uma fonte artificial de água; etc.”. Observações ulteriores: no caso citado, as intervenções humanas não alteraram a superfície potenciométrica, apenas a alcançaram. Contudo, em outros casos - como o enchimento de reservatórios pela construção de barragens, onde as intervenções humanas elevam o nível da superfície freática nos arredores, a proteção das nascentes que porventura surgirem é recomendável pelo estabelecimento de APP.

- Dominialidade de nascentes. Contexto: obstrução do acesso à nascente e desinstalação de tubulações e mangueiras de captação no local por proprietário de terra que construiu muros para evitar que vizinhos utilizassem a água de sua propriedade. Questão: respeito aos limites da APP? Parecer: necessidade de checar os eventuais danos à APP. Ressalva de que a água é de domínio público e que o proprietário não pode impedir o acesso à área para a dessedentação humana e de animais.

- Nascentes e solos com elevado grau de hidromorfismo. Contexto: propriedade instalada na Serra da Mantiqueira cujo terreno é constituído por colúvio com ponto de afloramento da água variável ao longo do ano. O nome indígena faz referência à presença de nascentes: "serra que chora”. Instalação de sistema de drenos artificiais para possibilitar a construção de moradia. Questão: a residência estaria em área de APP? Parecer: a polêmica na determinação da nascente refere-se ao caráter intermitente das surgências de água na área, com alternâncias de períodos de encharcamento (coincidente com incremento nas taxas de pluviosidade) e períodos em que a drenagem do terreno é suficiente para mantê-lo seco (decréscimo nas taxas de pluviosidade). Impossibilidade de conclusão pelo conceito de perenidade de nascentes estabelecido pela Lei 12.651/2012 para a delimitação de APP. Além disso, checagem da existência de nascentes na área restava prejudicada, em função da construção de drenos artificiais. O solo no local apresentava características de condições de hidromorfismo.

- Determinação de danos causados às nascentes do Rio São Francisco em vários municípios mineiros por culturas de cana de açúcar. Questão: dificuldade de realização de levantamento e monitoramento múltiplo e sistemático de nascentes pelos órgãos ambientais de Minas Gerais. Parecer: inviabilidade de atendimento de demanda inespecífica.

\section{b) Veredas}

- Determinação de vereda e nascente. Contexto: a demanda decorreu de constatação de divergências entre pareceres técnicos a respeito de existência de nascente e vereda em campo de 
obras, com reflexo na aplicação das normas ambientais de proteção e consequente limitação de atividades impactantes. Questão: determinar a ocorrência de Área de Preservação Permanente (APP) de veredas. Parecer (adaptado): Verificação de dificuldade no uso do conceito de vereda pelos interlocutores de diferentes ramos, com repercussões negativas na aplicação das normas protetivas das APPs. Embora haja mais de uma definição para o termo, segundo os pesquisadores da Embrapa (Ribeiro \& Walter 1998), a vereda é uma das quatro formações ou comunidades vegetais savânicas do bioma Cerrado, ou seja, é de um ambiente tipicamente aberto, não-florestal (sem dossel contínuo, com mais de $3 \mathrm{~m}$ de altura), formado pelo somatório das copas das árvores, quando estas cobrem ou sombreiam mais de $60 \%$ do chão. (Eiten 1983), onde predominam espécies de ervas e arbustos. A única árvore que se destaca na vereda é a palmeira buriti Mauritia flexuosa, geralmente perfilada, formando uma espécie de caminho ou alameda, situação que originou o nome comum para esse tipo particular de ambiente. Geralmente as veredas são circundadas por formações campestres, como o Campo Limpo Úmido (Ribeiro \& Walter 1998).

Além disso, embora todas as Veredas apresentem a palmeira buriti Mauritia flexuosa (ou Mauritia vinífera) como o único elemento arbóreo destacado entre plantas de porte baixo, a simples presença do buriti não caracteriza uma vereda, visto que a espécie pode estar presente em matas de galeria ou ciliares, que bordejam os cursos d'água (Felfili et al. 2001), ou em formações chamadas "palmeirais" - no caso, buritizais (Ribeiro \& Walter 1998), que têm composição botânica e estrutura particulares. O buritizal não deve ser confundido com vereda. No buritizal há formação de dossel, ainda que descontínuo, embora não haja uma vegetação arbustivo-herbácea associada da maneira típica como na vereda. O dossel do buritizal possui altura variável de 12 a 20 metros e forma uma cobertura quase homogênea ao longo do ano, variável de $40 \%$ a $70 \%$ (Ribeiro \& Walter, 1998).

Mas não é apenas a fisionomia e a composição florística que caracterizam uma vereda. Os autores citados esclarecem que a ocorrência de veredas está associada à surgência do lençol subterrâneo de água (nível da superfície freática), pelo que essas formações vegetais são encontradas somente em solos com condições de hidromorfismo, cuja cor, textura e composição têm relação direta com condições de encharcamento contínuo.

Quanto ao papel ecológico das veredas, elas são de fundamental importância na proteção de nascentes (Araújo et al. 2002) e na manutenção da fauna do Cerrado, "funcionando como local de pouso para a avifauna, atuando como refúgio, abrigo, fonte de alimento e local de reprodução também para a fauna terrestre e aquática” (Ribeiro \& Walter 1998).

No caso específico, concluiu-se que as alterações antrópicas não permitiam caracterizar a área como pretérita vereda. Além disso, na investigação dos arredores apenas foram encontrados buritis em contexto de mata de galeria.

\section{c) Áreas Úmidas}




\section{- Áreas úmidas em contexto de nascentes difusas e campos de murundus no Distrito Federal.}

Ocupação no interior da Área de Proteção de Mananciais da Área de Proteção Ambiental do Rio Descoberto e da Zona de Amortecimento da Floresta Nacional de Brasília. Questão: Campos de Murundus são considerados Áreas Úmidas? São passíveis de delimitação de APP? Quais os tipos de solo encontrados na propriedade? Há solo hidromórfico? Qual a importância dos solos hidromórficos para a rede hidrográfica local? Qual a relação dos solos hidromórficos com áreas encharcadas/úmidas ou nascentes? Qual a importância ecológica do campo de murundus? Qual a sua relação com a rede hidrográfica local? O campo de murundus é importante para a conservação da água de superfície? Há proteção legal, distrital ou federal, para essa formação (campos de murundus)? Em que consiste essa proteção legal? Parecer: elaboração de quesitos judiciais.

\subsection{Proposta conceitual}

\subsubsection{CONCEITO DE NASCENTE}

Nascente é um local de descarga natural da água subterrânea na superfície do terreno que gera fluxo visível. As principais causas de afloramento da água subterrânea no terreno são:

- Relações entre o rebaixamento da superfície do terreno e a superfície potenciométrica;

- Contraste de condutividade hidráulica entre dois meios;

- Existência de estrutura geológica (fraturas ou falhas);

- Presença de surgências em regiões cársticas;

- Elevação da superfície potenciométrica do aquífero por causas naturais ou por barramentos/instalação de reservatórios de água; e

- Associações das causas anteriores.

O fluxo a partir da nascente é condicionado pela diferença entre a elevação da superfície potenciométrica no aquífero e a elevação da superfície do terreno onde a descarga ocorre.

Conforme a proposta desta revisão conceitual, cabeceira é o conjunto de nascentes e olhos d’água que compõe o alto curso da bacia hidrográfica (Figura 19). Durante o ciclo hidrológico, há variação da superfície potenciométrica do aquífero, o que pode deslocar o ponto de afloramento da água subterrânea ao longo do talvegue. Nesses casos, segundo a definição, a nascente é o ponto a partir do qual o fluxo é perene, ou seja, onde a superfície potenciométrica é mínima ao longo de um ciclo hidrológico. 

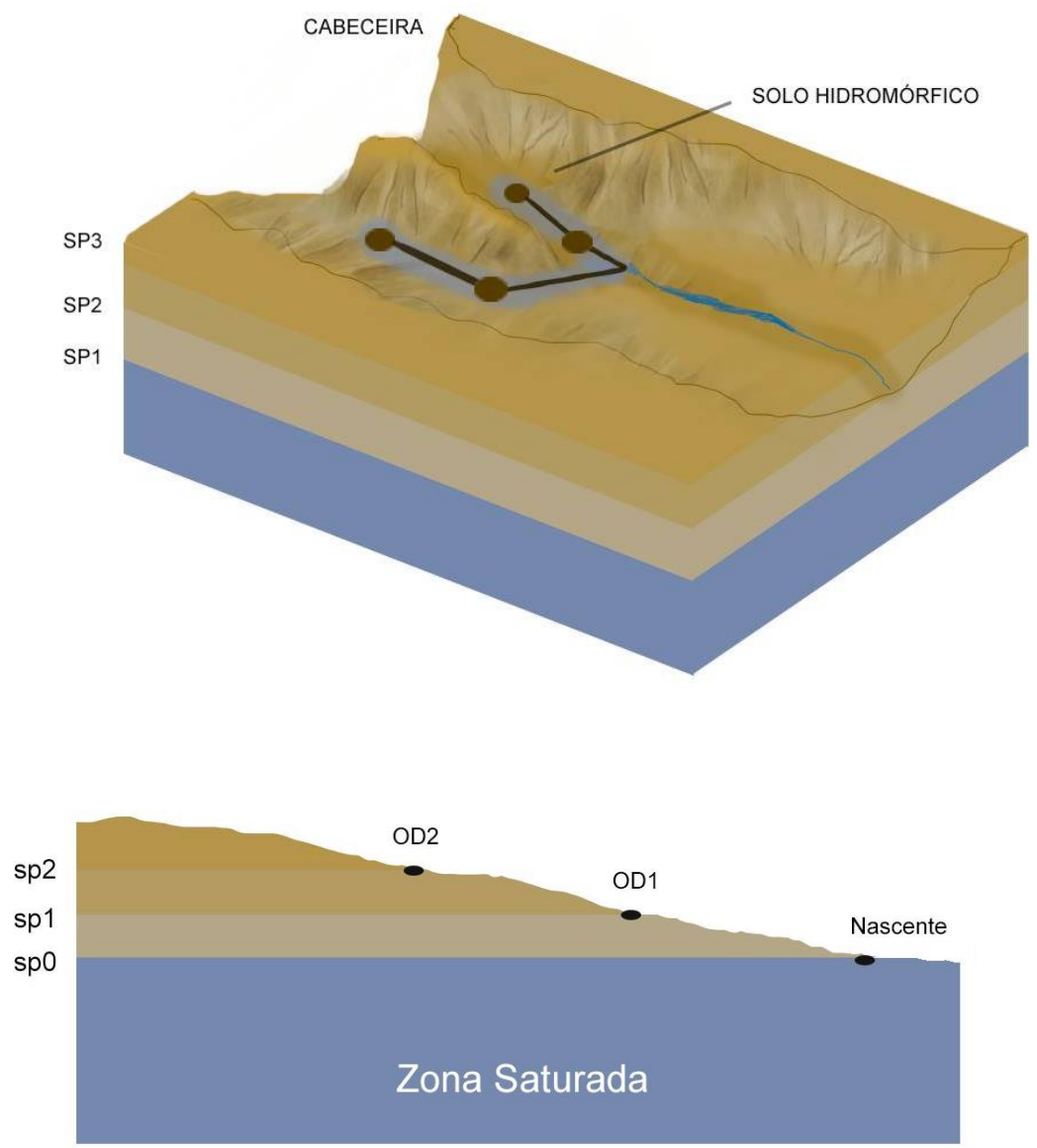

Figura 19 - Modelo conceitual de cabeceira: conjunto de nascentes e olhos d'água que compõe o alto curso da bacia hidrográfica. Superfície Potenciométrica (SP) varia ao longo do ciclo hidrológico e desloca o ponto de afloramento de água (Olho d'água - OD). Nascente é o ponto a partir do qual o fluxo é perene.

Quando o fluxo não pode ser imediatamente observado, mas a superfície do terreno é úmida em comparação à área de entorno, ou seja, quando o solo apresenta elevado grau de hidromorfismo (Figura 20), a descarga da água subterrânea é chamada de área úmida.

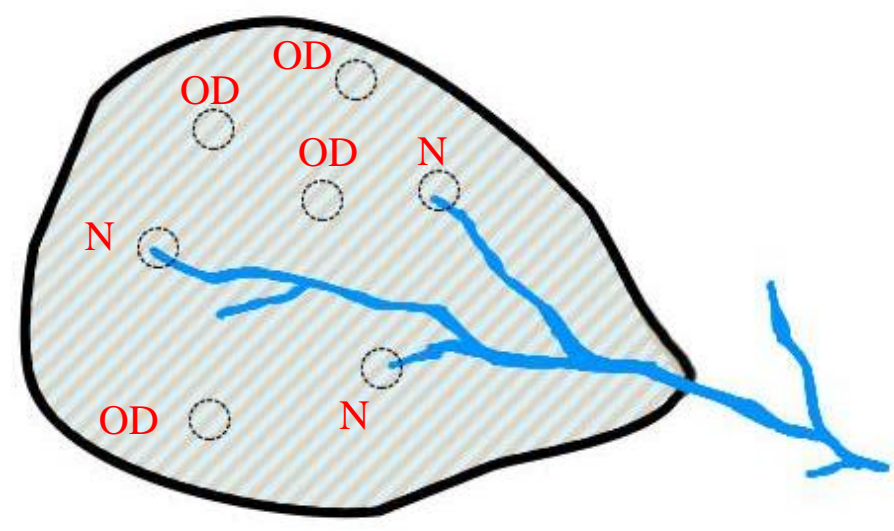

Figura 20 - Descarga de água subterrânea é denominada AU quando o fluxo d'água não pode ser imediatamente observado a partir de olhos d'água (OD). Caso de nascentes $(\mathrm{N})$ difusas/secundárias em contexto de solos com elevado grau de hidromorfismo. 
Quando há um olho d'água, isto é, onde há intersecção da superfície potenciométrica em relação ao terreno, porém não há fluxo visível ou perene, também considera-se área úmida, como em alguns casos observados no semiárido (Figura 21).

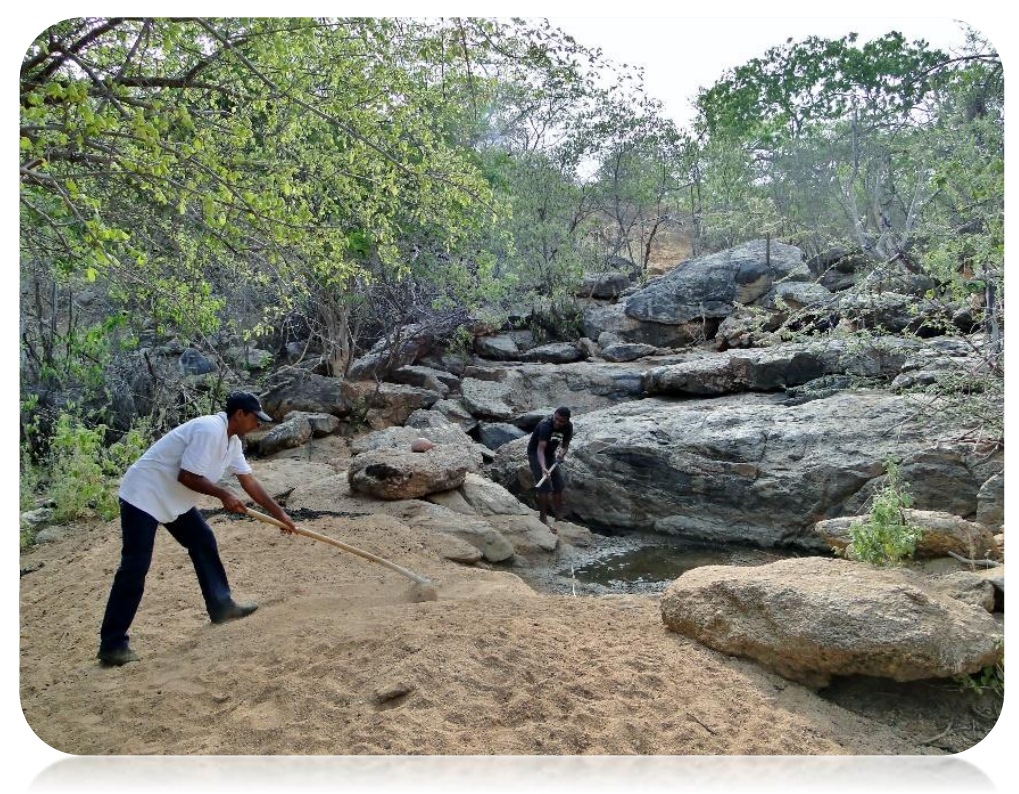

Figura 21 - Olho d'água no semiárido, Serra da Joaninha entre Tauá e Independência - Ceará. Fonte: Aurélio Rodrigues de Loiola Junior.

Com exceção da região sul com chuvas bem distribuídas ao longo do ano, na maior parte do Brasil o ciclo pluviométrico é bimodal, ou seja, há um período mais chuvoso e outro mais seco (Cunha et al. 2015). Isso implica que durante o ano há uma época em que o regime seco impõe reduções na recarga do aquífero, o que faz com que o nível da superfície potenciométrica diminua progressivamente até um limite mínimo alcançado no final do período seco. É nesse momento em que é possível determinar o ponto a partir do qual o fluxo de água é perene (ou seja, a nascente), embora existam locais em que o curso do rio seca. O conceito de cursos d'água intermitentes (Lei 12.651/12, Art. $4^{\text {o }}$ I) possui particular importância no semiárido brasileiro. Nesses casos, não ocorre nascente, por definição, mas os olhos d'água associados aos cursos d'água temporários devem reconhecidos como áreas úmidas, ou seja, áreas transicionais entre os ambientes aquáticos e terrestres, sazonais. Ou seja, por esta proposta metodológica, a proteção dos olhos d'água não estaria vinculada às APPs de nascente (FIG. 22), mas aos instrumentos legais de proteção de AUs, entre os quais a delimitação de APPs orientadas pelo instrumento do Inventário Brasileiro de Áreas Úmidas. 

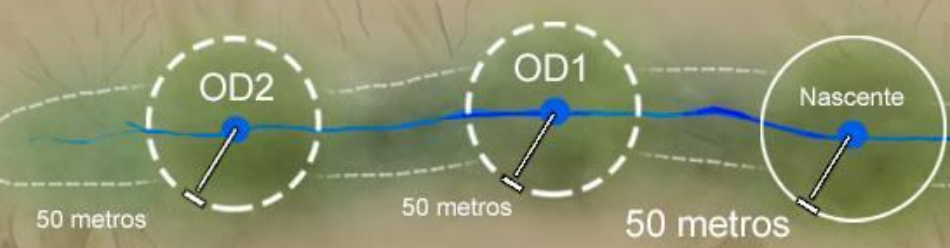

30 metros

Figura 22 - APP de nascente apenas é garantida a partir de ponto em que o afloramento de água é perene (circunferência com raio de $50 \mathrm{~m}$ representada por traço contínuo na figura). Os olhos d'água (representados na figura por OD 2 e OD1) não são protegidos por APP de nascente (simulada apenas ilustrativamente por linha tracejada), mas por instrumento de proteção próprio a ser estabelecido a partir de Inventário Brasileiro de Áreas Úmidas. De qualquer maneira, toda a linha do talvegue é protegida por APP de curso d'água (de $30 \mathrm{~m}$ no caso do exemplo da figura), garantida na legislação inclusive para rios sazonais - excluídos os efêmeros.

Acredita-se que o emprego dessa proposta integra os conceitos técnico-científicos com a favorável aplicação da legislação ambiental, por reconhecer os olhos d'água como áreas úmidas e a garantia de sua legítima proteção a partir de zoneamentos baseados no Inventário Brasileiro de Áreas Úmidas. Isso porque diferentes instrumentos de proteção podem ser implementados conforme as funções ecossistêmicas e os serviços ambientais desempenhados.

Acredita-se que as áreas de cabeceira, compostas por configuração de conjunto de olhos d'água e nascentes em áreas frequentemente delimitadas por solos com elevado grau de hidromorfismo, são ambientes prioritários para o fomento de reservas legais no âmbito do CAR ou de programas de monitoramento e mitigação no âmbito do licenciamento ambiental, por exemplo. Além disso, os olhos d'água sazonais em contexto como o semiárido nordestino, sujeitos a pulsos plurianuais de curta duração, devem ser foco de emprego de diversos instrumentos legais integrados para garantir sua proteção, como os incentivos e benefícios da servidão ambiental (Previstos na Política Nacional de Meio Ambiente - PNMA e na Lei 12.651/12); integração do Plano Estratégico Nacional de Áreas Protegidas - PNAP e da Política Nacional de Recursos Hídricos - PNRH para garantir a proteção dos olhos d'água de acordo com o plano de recursos hídricos, com instrumento de outorga e com a eventual criação de áreas sujeitas a restrição de uso; em consonância com o zoneamento de áreas críticas previsto na Política Nacional de Biodiversidade; e com a Política Nacional da Educação Ambiental - PNEA, para a divulgação e conscientização sobre os conceitos e orientações para a conservação ambiental.

Pela complexidade de contextos e possíveis associações de condicionantes do afloramento, os modelos conceituais a elaboração de modelos deve ser feita caso a caso. Em termos de aplicação, a escala de análise é progressivamente mais detalhada quanto o foco for deslocado do 
estudo de cabeceiras (abordagem de gestão de bacias hidrográficas) em direção ao estudo em escala de empreendimentos e atividades potencialmente impactantes (abordagem de licenciamento ambiental) e, por fim, no contexto de propriedade (abordagem de planejamento territorial, Zoneamento Ecológico Econômico e Cadastro Ambiental Rural - CAR).

Em casos de lides judiciais quanto a intervenções em APP de nascente, sugere-se a realização de levantamentos em malha apertada. O nível de exigência quanto ao emprego dos métodos de caracterização e de determinação, por outro lado, vincula-se ao risco da atividade ou grau de segurança ambiental que se pretende garantir à nascente, olho d'água ou sistema de interface entre o aquífero e a superfície.

À parte dessas discussões de cunho essencialmente voltado à proteção ambiental, esta proposta conceitual propõe também a sistematização do termo fonte. Com base na definição de fonte do texto do Código de Águas Minerais - Decreto-Lei $\mathrm{n}^{\mathrm{o}} 7.841^{7}$, de 8 de agosto de 1945 (BRASIL 1945), propõe-se que "fonte" seja empregada em referência às nascentes, olhos d'água ou mecanismos de captação de água subterrânea para uso humano (com finalidades paisagísticas, recreativas ou de consumo).

Em síntese, esta dissertação apresenta como produto da revisão conceitual de nascentes a seguinte proposta conceitual dos termos nascentes, olhos d'água, cabeceira e fontes:

Tabela 5 - Proposta conceitual: nascente, olho d'água, cabeceira e fonte.

\begin{tabular}{|c|c|c|c|}
\hline Nascente & Olho d'água & Cabeceira & Fonte \\
\hline $\begin{array}{l}\text { Nascente é um local de } \\
\text { descarga natural da água } \\
\text { subterrânea na superfície } \\
\text { do terreno que gera fluxo } \\
\text { visível. Localiza-se na } \\
\text { base da cabeceira, ou } \\
\text { seja, é o ponto de } \\
\text { superfície potencial } \\
\text { mínima ao longo de um } \\
\text { ciclo hidrológico anual } \\
\text { (seja bimodal, com } \\
\text { períodos seco e chuvoso, } \\
\text { ou monomodal, com } \\
\text { chuvas bem distribuídas } \\
\text { ao longo do ano). }\end{array}$ & $\begin{array}{l}\text { É o local de descarga } \\
\text { natural da água } \\
\text { subterrânea } \\
\text { superfície do terreno } \\
\text { que pode ou não gerar } \\
\text { fluxo visível e que pode } \\
\text { ser sazonal ou perene, } \\
\text { com base em um ciclo } \\
\text { hidrológico anual. } \\
\text { Considera-se, } \\
\text { individual } \\
\text { coletivamente, como } \\
\text { área úmida. }\end{array}$ & $\begin{array}{l}\text { Conjunto de } \\
\text { nascentes e olhos } \\
\text { d'água que compõe } \\
\text { o alto curso da } \\
\text { bacia hidrográfica. }\end{array}$ & $\begin{array}{lr}\text { Nascentes, olhos } \\
\text { d'água } & \text { ou } \\
\text { mecanismos } & \text { de } \\
\text { captação de água } \\
\text { subterrânea para } \\
\text { consumo humano. }\end{array}$ \\
\hline
\end{tabular}

\footnotetext{
${ }^{7}$ que restringe o título de fontes de água mineral àquelas que possuem condições físicas ou físico-químicas com ações medicamentosas (Art. $1^{\circ}$ ).
} 


\subsubsection{CONCEITO DE VEREDA}

Categoria de área úmida caracterizada pela associação de nascentes, que geram um curso natural de água, com solos sujeitos a condições de hidromorfismo, em locais com ocorrência de savana sul-americana e relevo plano a levemente ondulado. Na América do Sul, esse contexto favorece o desenvolvimento de macrohabitat típico (Figura 23), cuja flora é geralmente tipificada por palmáceas como o buriti associadas à vegetação rasteira, e os demais reinos dos seres vivos adaptados às condições promovidas pela disponibilidade de água (com baixa concentração de oxigênio dissolvido, matéria orgânica moderada, $\mathrm{pH}$ baixo a neutro), alta radiação solar e espaços abertos - pela ausência ou pouca formação de dossel.

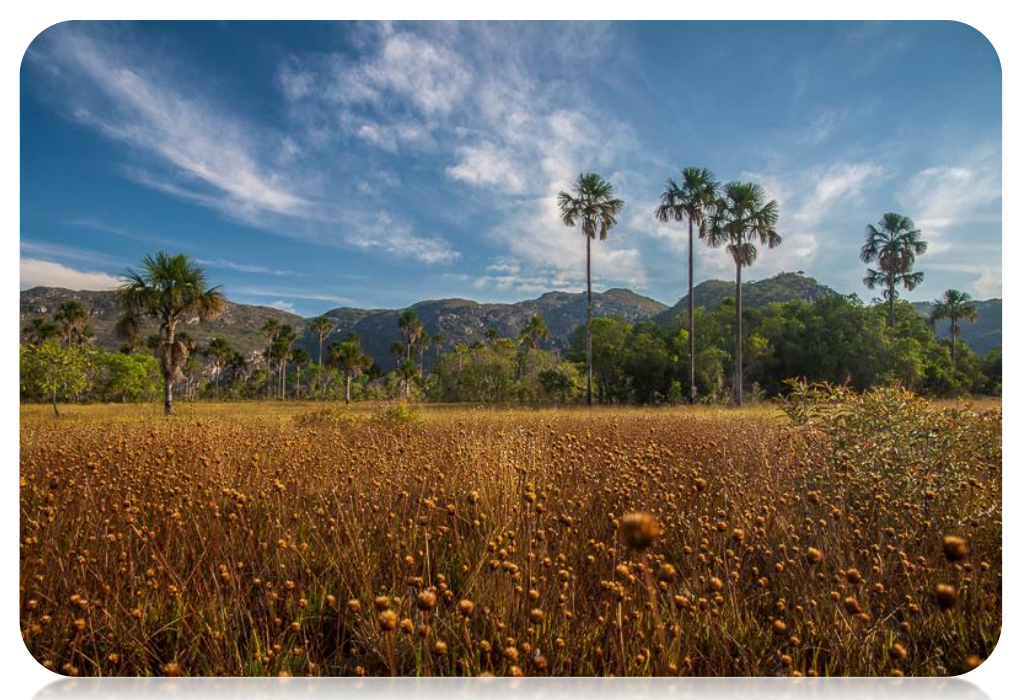

Figura 23 -Vereda típica: área úmida caracterizada por renque de buritis associada à vegetação rasteira. Parque Nacional das Sempre-Vivas, Diamantina/MG. Fonte: < http://www.andredib.com.br/galeria/parques-nacionaisbrasileiros/?id=33>. Acesso em: 23 nov. 2015.

A conceituação proposta considera como critério identificador o solo com elevado grau de hidromorfismo e como critério tipificador a presença de complexo vegetacional do cerrado adaptado ao ambiente de transição terrestre/aquático, com buritis.

Há outros ambientes condicionados a áreas úmidas (solos com elevado grau de hidromorfismo, várzeas etc.) associados a curso d'água regular de maneira semelhante às veredas típicas, mas tipificados por outras espécies da família Arecáceas (Figura 24), popularmente conhecida por "palmáceas” (açaizais, carnaubais etc.), que tifipificam outras categorias de AUs.

Veredas são classificadas como áreas úmidas interiores, com nível de água relativamente estável em áreas pantanosas com vegetação mista, segundo a chave de classificação proposta por Cunha et al. (2015). Já os buritizais e carnaubais são considerados pela mesma chave de classificação como áreas úmidas interiores com nível de água relativamente estável em áreas florestadas pantanosas. 


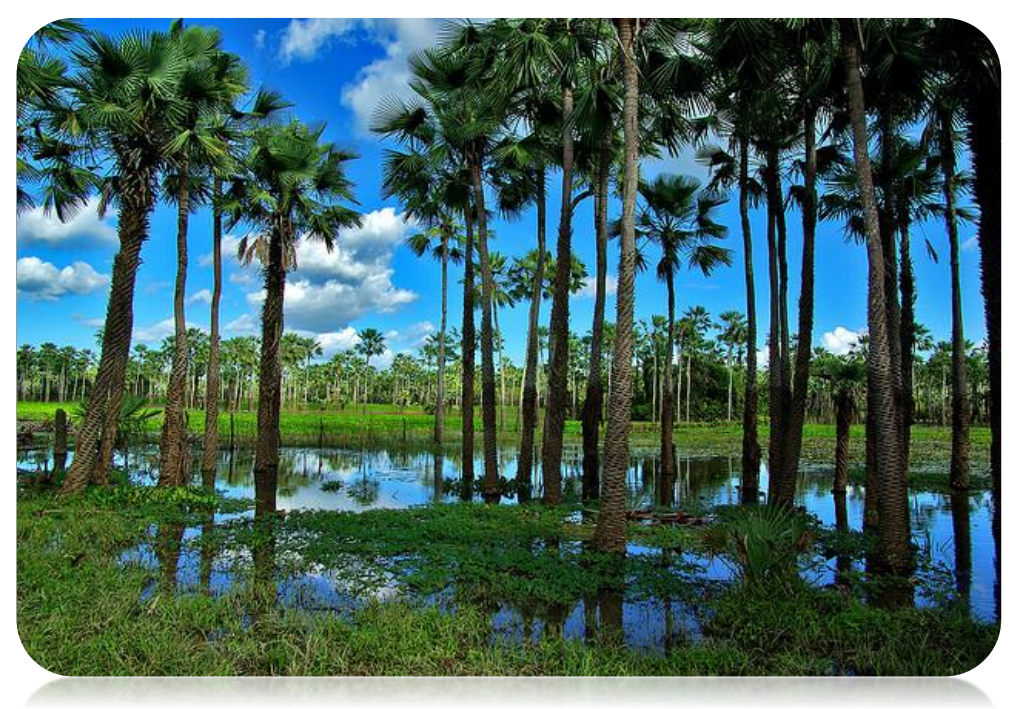

Figura 24 - Carnaubal, outra categoria de área úmida tipificada pela fitofisionomia que deve ter sua proteção garantida. Fonte: Otávio Nogueira, "De volta pro meu Ceará". Disponível em: <https://www.flickr.com/photos/55953988@N00/3789299095/>. Acesso em: 23 nov. 2015.

No cerrado, a concentração de palmáceas é variável ao longo do complexo vegetacional e não forma apenas renques ou alamedas, mas também dossel, ao longo de uma mesma vereda (como no caso do sistema Vereda Grande/Córrego do Brejinho em Águas Emendadas - DF, que em aproximadamente 6,5 $\mathrm{Km}$ apresenta amplo gradiente de concentração de buritis, associados a variação gradativa de vegetação gramínea/arbustiva). Além disso, observa-se que a vereda é dinâmica e transicional com mata de galeria/mata ciliar, mata alagada, campo úmido etc. Por esse motivo, é considerada como complexo vegetacional (Brandão et al. 1991; Araújo et al. 2002; Walter 2006; Seduma 2008; Cunha et al. 2015).

Esta integração de conceitos de áreas úmidas de pequenas dimensões condicionadas pelo elevado grau de hidromorfismo do solo associadas ao contexto de nascentes se aplica ao caso do macrohabitat das veredas, por exemplo. Segundo a sistematização induzida pela Chave de Classificação (INAU 2015), as veredas enquadram-se como:

Áreas Úmidas naturais (sistema); interiores (subsistema); com nível de água relativamente estável (ordem); em áreas pantanosas com vegetação mista (subordem); condicionadas por solo com elevado grau de hidromorfismo associado a cabeceira de curso de água (classe); em savana (subclasse); cujo complexo vegetacional de buritis com espécies gramíneas e arbustivas tipifica a vereda (macrohabitat).

\subsubsection{CONCEITO DE ÁREAS ÚMIDAS}

As áreas úmidas - AUs são ambientes transicionais ou de interface entre os ambientes aquáticos e terrestres.

Incluem todos os ecossistemas transicionais entre os ambientes aquáticos e terrestres 
(Figura 25), naturais ou artificiais, associados ao ciclo das águas interiores e costeiras, com o nível de água variável ou relativamente estável ao longo do tempo, cujos solos apresentam elevado grau de hidromorfismo, condicionados por águas de origem pluvial, fluvial, marinha, subterrânea ou de combinações entre elas, com contribuição de marés ou não, com comunidades de plantas e animais adaptadas à dinâmica hídrica.

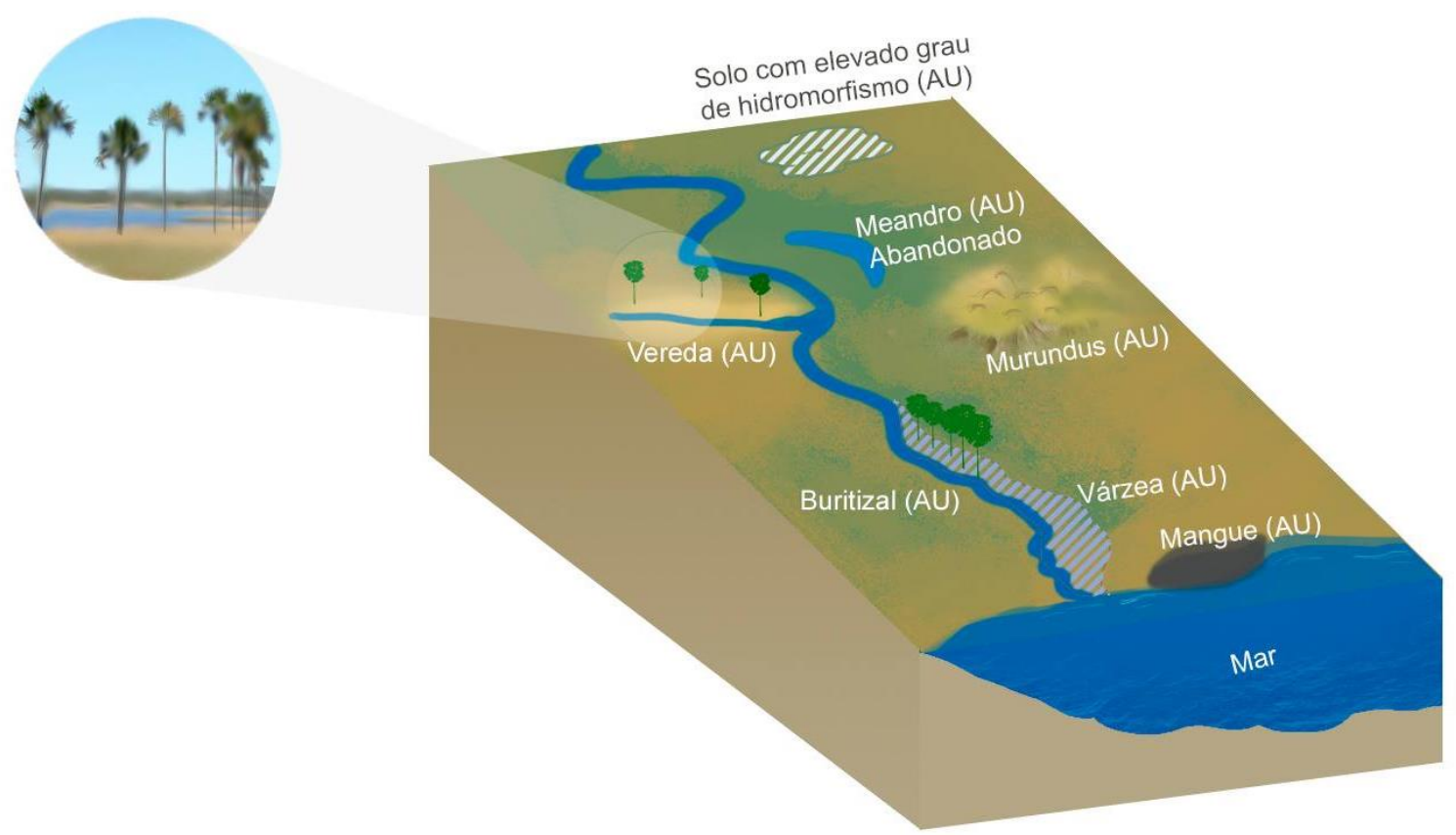

Figura 25 - Modelo conceitual exemplificativo de algumas das categorias de áreas úmidas. Notar que solo com elevado grau de hidromorfismo é colocado genericamente como referência de critério identificador de áreas úmidas de pequenas dimensões, referidos de maneira indistinta (brejos, banhados, campos úmidos etc). Destaque para a vereda, conceituada nesta dissertação como categoria de AU.

A detalhada Chave de Classificação de AUs (Cunha 2015) desenvolve-se a partir das categorias que consideram diversos critérios escalonados. A análise da Chave de Classificação parece induzir à seguinte delimitação categórica de Áreas Úmidas:

- Sistemas: naturais ou antropogênicos. Critério: gênese.

- Subsistema: costeiras ou interiores. Critério: localização em relação ao mar.

- Ordem: nível de água ao longo do tempo. Critério: temporalidade.

- Subordem: variações da ordem pelo contexto espacial. Critério: espaço.

- Classe: identificação da área úmida: Critérios: características identificadoras, a exemplo de solos com elevado grau de hidromorfismo.

- Subclasse: variações da classe pela paisagem. Critérios: gradientes das características identificadoras em função do bioma, geomorfologia, clima.

- Macrohabitat: conjunto de características ambientais integradas que permitem o uso do espaço por organismos típicos. Critério: características tipificadoras.

A citada Chave de Classificação é uma ferramenta de grande potencial na gestão de áreas 
úmidas e constitui a base para a elaboração do Inventário de Áreas Úmidas Brasileiras a ser utilizada no planejamento territorial. A complexidade das categorias demanda um grande esforço científico colaborativo multidisciplinar nacional para alimentação de dados dos diversos contextos regionais, locais e pontuais no Brasil. O INAU, além de idealizar, estruturar, divulgar e estimular o diálogo sobre a Chave de Classificação de AUs Brasileiras, centraliza as referências sobre as grandes áreas úmidas relativas ao Pantanal Mato-grossense e as Várzeas Amazônicas, compiladas pela Universidade Federal de Mato Grosso (Cunha 2015).

Esta dissertação busca colaborar com a compreensão das classes de áreas úmidas cujos critérios identificadores envolvam solos com elevado grau de hidromorfismo, em geral relacionados às áreas úmidas de pequenas dimensões, que muitas vezes integram um contexto de associação a locais de descarga natural da água subterrânea. Portanto, integra fundamentos de nascentes, olhos d'água e cabeceiras (tópico 2.5.1) com fundamentos sobre fatores condicionantes de solos com elevado grau de hidromorfismo (Capítulo 3). Neste caso, a principal contribuição que este estudo busca enfocar é a elucidação do papel dos solos com elevado grau de hidromorfismo como critério identificador de áreas úmidas. Acredita-se que outros critérios multidisciplinares podem ser úteis na tipificação de AUs.

O conceito adotado pela convenção de Ramsar em processo de constante aprimoramento abrange as mais diversas áreas úmidas, com suas funções ambientais, sociais e econômicas interrelacionadas. Corpos hídricos como olhos d'água, meandros abandonados, lagoas marginais e diversas situações de solos com elevado grau de hidromorfismo são compreendidas dentro de um arcabouço de proteção, que não se restringe à lei florestal brasileira, mas que a incorpora com outras políticas nacionais, como a dos recursos hídricos, das unidades de conservação, da diversidade biológica, todas em consonância com a Convenção de Ramsar.

Por esse conceito, excluem-se como áreas úmidas sistemas hídricos antropogênicos ligados a obras urbanas de redes de abastecimento e de esgoto, como piscinas, fontes de água artificiais e outros reservatórios artificiais em contexto urbano, que não constituem um macrohabitat. 


\section{CAPÍTULO 3}

\section{PROPOSTA METODOLÓGICA}

A partir dos conceitos desenvolvidos, propõe-se que modelos conceituais sejam elaborados caso a caso para a aplicação de instrumentos de proteção de nascentes, veredas e áreas úmidas em geral. Em vista da complexidade e da dinâmica dos contextos no Brasil, a avaliação de diferentes determinantes pode ser a chave para uma aplicação mais razoável da legislação.

O primeiro passo para a elaboração de modelo conceitual é a determinação do alvo de interesse e do objetivo do estudo. A condução dos estudos varia de acordo com o enfoque da análise para as feições hídricas em questão e com o instrumento de proteção que se pretende empregar. Por exemplo, se o modelo conceitual se destina à avaliação de cabeceiras em um contexto de bacias hidrográficas, com a finalidade de determinação das áreas de contribuição e da rede de drenagem para a gestão dos recursos hídricos, a escala de análise cartográfica abrange toda a bacia e não enfoca detalhes sobre a caracterização de nascentes, veredas e áreas úmidas. Ou seja, o enfoque primordial é a determinação espacial - localização - e temporal - perenidade, sazonalidade ou efemeridade - das feições hídricas.

Já as análises de feições hídricas no contexto dos instrumentos de Avaliação de Impactos Ambientais - AIA, entre os quais os licenciamentos baseados na elaboração de Estudos de Impacto Ambiental e Relatório de Impacto Ambiental - EIA/RIMA, os estudos multiescalares, multitemporais e multidisciplinares são indispensáveis para o emprego de instrumentos de proteção específicos de acordo com o empreendimento/atividade e os seus impactos associados. Neste caso, tanto a determinação, quanto a caracterização integradas são exigidas em múltiplas escalas, com avaliações temporais complementares para a proposição de cenários ou de programas de prevenção, monitoramento e mitigação.

As análises de APPs associadas a nascentes e áreas úmidas em propriedades, por outro lado, geralmente demandam determinação de detalhe (frequentemente dispensam análises regionais), e, por vezes, exigem análises temporais nos casos de apuração de intervenções pretéritas diante da necessidade de recomposição vegetacional ou de fenômenos temporais (como a investigação da perenidade, sazonalidade ou efemeridade de afloramentos de água subterrânea ou de encharcamento em áreas úmidas). A caracterização não é uma exigência para nascentes, mas no caso de áreas úmidas, como veredas, é importante para a aplicação da legislação conforme as características tipificadoras que possui (caracterização da vegetação, por exemplo).

O estudo de nascentes, veredas e demais áreas úmidas em Unidades de Conservação pode envolver análises integradas multiescalares, multidisciplinares e multitemporais. Nestes casos, o objeto de estudos é amplo, a análise é sistêmica e objetiva não só a aplicação de variados 
instrumentos de proteção, como também a realização da pesquisa investigativa com fins científicos e didáticos. Como muitos dos aspectos envolvidos nas metodologias aplicadas para os fins supracitados também estão envolvidos na determinação e caracterização de feições hídricas nas unidades de conservação, elas representam um laboratório de desenvolvimento de determinação e caracterização das feições hídricas. Além disso, pesquisas e atividades técnicas são estimuladas em várias categorias dessas áreas especialmente protegidas. Por estes motivos, a aplicação dos métodos discutidos neste capítulo é compilada no estudo de caso na Estação Ecológica de Águas Emendadas (ESEC-AE), no Distrito Federal (Capítulo 4).

Para o estudo de nascentes, veredas e áreas úmidas em geral é favorável seguir etapas que embasem os critérios de determinação e caracterização das feições. O método escalonado parte da seleção da escala de trabalho e compreensão em diferentes dimensões a partir dos levantamentos espaciais e de estudos temporais para avaliação da sazonalidade, perenidade ou efemeridade das feições; da obtenção de dados multidisciplinares por meio de levantamentos bibliográficos, - com a contextualização multidisciplinar em caráter regional e local das feições hídricas; e dos levantamentos de campo para validação e refinamento dos dados.

A partir da primeira etapa de determinação (tópico 3.1), delimitam-se as feições que são objeto do estudo e as escalas espacial e temporal da análise. Ou seja, a primeira etapa oferece como produto a identificação espaço-temporal das feições.

Na segunda etapa, a caracterização (tópico 3.2) consiste na descrição das feições, detalhada conforme a necessidade da análise, com o objetivo de fundamentar os modelos conceituais e realizar a tipificação das feições hídricas. A integração das análises qualitativas de determinação e de caracterização das feições permite gerar como produto a elaboração de modelos conceituais. Os modelos conceituais agregam elementos para a adequada aplicação de instrumentos de proteção das feições hídricas (tópico 3.3).

Etapa 1: determinação $\rightarrow$ critérios identificadores (espaciais e temporais);

Etapa 2: caracterização $\rightarrow$ critérios tipificadores (descritivos).

\subsection{DETERMINAÇÃo DE FEIÇõES}

A determinação de feições inicia-se com a definição de uma área de estudo, para a qual se adapta a escala de abordagem. Nesta etapa, as feições hídricas são observadas como fenômenos no espaço e no tempo. A obtenção dos dados deve ser direcionada ao objetivo da questão, conforme critérios de identificação pré-estabelecidos. Para delimitar nascentes e áreas úmidas em geral são realizados levantamentos espaciais, com a definição das escalas de análise, de levantamento e de representação. Complementarmente, a partir de análise temporal, definem-se cenários para o entendimento do processo associado ao fenômeno. 


\subsubsection{Levantamentos espaciais: critérios de identificação e escala}

\section{a) Critérios de identificação}

Para a identificação de cabeceiras - com a abrangência de olhos d'água, nascentes e eventuais fontes - geralmente são utilizadas como critério espacial as redes de drenagens naturais, também conhecidas como linhas d'água. Olhos d'água podem ser identificados a partir de grotas na origem das quebras de relevo dos talvegues, no topo das cabeceiras. Nascentes localizam-se no ponto da rede de drenagens a partir do qual o fluxo é permanente. A partir desse ponto, geralmente a vegetação é mais densa e forma mata de galeria. A identificação de fontes de água (ou seja, as nascentes cujas águas são próprias para o consumo humano) deve ser feita por meio de análises dos parâmetros de qualidade d'água em relação aos padrões estabelecidos pela Portaria 2.914, de 12 de dezembro de 2011, do Ministério da Saúde (Brasil 2011), que estabelece os procedimentos e responsabilidades relativos ao controle e vigilância da qualidade da água para consumo humano e seu padrão de potabilidade, e dá outras providências.

Como critério identificador de áreas úmidas em geral (incluídas as veredas), propõe-se nesta dissertação a utilização dos solos com elevado grau de hidromorfismo. De fato, esse critério identificador de AUs já vem sendo empregado em estudos técnicos ou acadêmicos, quando "as manchas de umidade" são delineadas por meio de técnicas de geoprocessamento e sensoriamento remoto na manipulação de imagens orbitais ou de fotografias áreas.

Em todos os casos de determinação espacial de feições hídricas, julga-se fundamental a validação em campo (e eventualmente em laboratório) de sua ocorrência. Os critérios de identificação são, assim, fundamentos orientadores para sua verificação espacial e delimitação.

\section{b) Escala}

Nos levantamentos espaciais, a escala compreende três vertentes complementares entre si: a escala de análise, a escala de levantamento e a escala de representação.

A escala de análise é a essência do problema investigado (Silva Filho 2011). A partir do objeto de análise e do interesse de estudo empregam-se as escalas que respondam às questões investigadas nos níveis adequados de detalhamento. O recorte científico não é terminativo, mas multiescalar conforme as questões e as respostas evoluem. Quando o fenômeno é dinâmico e envolve alterações ambientais, articular análises para compreender as mudanças é um desafio, pois a análise de homogeneidade e de heterogeneidades depende da escala (Santos 2004). Este é o caso das feições hídricas, especialmente em contextos em que se encontram associadas as nascentes, veredas e outras áreas úmidas em uma mesma escala de análise.

Nos levantamentos espaciais, sempre que possível, é recomendável a obtenção ou elaboração de mapas temáticos, com finalidade esquemática. O esquema representado no mapa compõe o modelo conceitual de compreensão do fenômeno, mas não o encerra. Além dele, representações gráficas em perfil, em bloco diagrama, em planta, em figuras, complementadas 
pelo registro textual, são úteis no desenvolvimento da avaliação qualitativa da feição hídrica e da aplicação adequada de instrumentos de proteção. A escala de representação em mapas deve ser entendida não apenas como "um recurso matemático que define uma relação geométrica entre medidas do real e aquelas da representação cartográfica, segundo uma proporção matemática" (Libault 1975), mas como a delimitação espacial do fenômeno que se deseja representar em um tempo determinado.

A representação cartográfica das informações espaciais deve ser clara e incluir a escala, o sistema de coordenadas, a projeção e o datum empregados. Este são requisitos básicos e muitas vezes omitidos em levantamentos com finalidades de aplicação de instrumentos de proteção ambiental em geral e até mesmo em publicações de caráter científico. Um exemplo disso, é a delimitação de APPs de nascentes, veredas e áreas úmidas em geral. A escala de representação só é de fato representativa com a integração dessas informações e disponibilização para a checagem por terceiros, caso contrário, questões de supostas intervenções investigadas podem ser questionadas em relação às imprecisões da fonte do dado. Além disso, na descrição de um fenômeno deve-se avaliar se a precisão gráfica é suficiente para representá-lo de maneira coerente (Silva Filho 2011).

Para Queiroz Filho (2005) a forma de representação dos fenômenos com elementos gráficos (feições de pontos, linhas e polígonos) depende da escala cartográfica para retratar a distribuição (isoladas ou concentradas, homogêneas ou heterogêneas). A determinação de nascentes geralmente tem representação gráfica pontual. Mas em alguns casos, como discutido na revisão conceitual, a cabeceira envolve em um mesmo contex to de anfiteatro um conjunto de olhos d'água associados a um afloramento de água subterrânea a partir da qual o fluxo é perene, em um contexto de solo com elevado grau de hidromorfismo. Nesses casos, a representação mais adequada é o polígono, com a consequente interpretação como área úmida. Por conceito, a delimitação poligonal aplica-se a todos os casos de áreas úmidas cujo critério identificador é o elevado grau de hidromorfismo do solo, onde não é possível determinar a localização da nascente, por ser difusa ou submersa - inclusive em veredas. Portanto, a representação gráfica mais adequada é do conjunto e não da feição individualizada.

A escala de levantamento refere-se à obtenção de dados em campo, por meios diretos ou indiretos. É a escala de percepção espacial da realidade que subsidia as escalas de representação cartográfica e de análise. As limitações na escala de levantamento estão relacionadas à malha de checagem do fenômeno e a outros fatores subjetivos, de múltiplas variáveis reais. A qualidade da escala de levantamentos de campo, ou seja, por meios diretos, depende da estatística de representatividade das feições. Localizar feições hídricas em campo, especialmente as pontuais como as nascentes ou olhos d'água, não é trivial. Há limitações de reconhecimento visual (Figura 26), de encaminhamento, de tempo, de recursos, entre outras. 

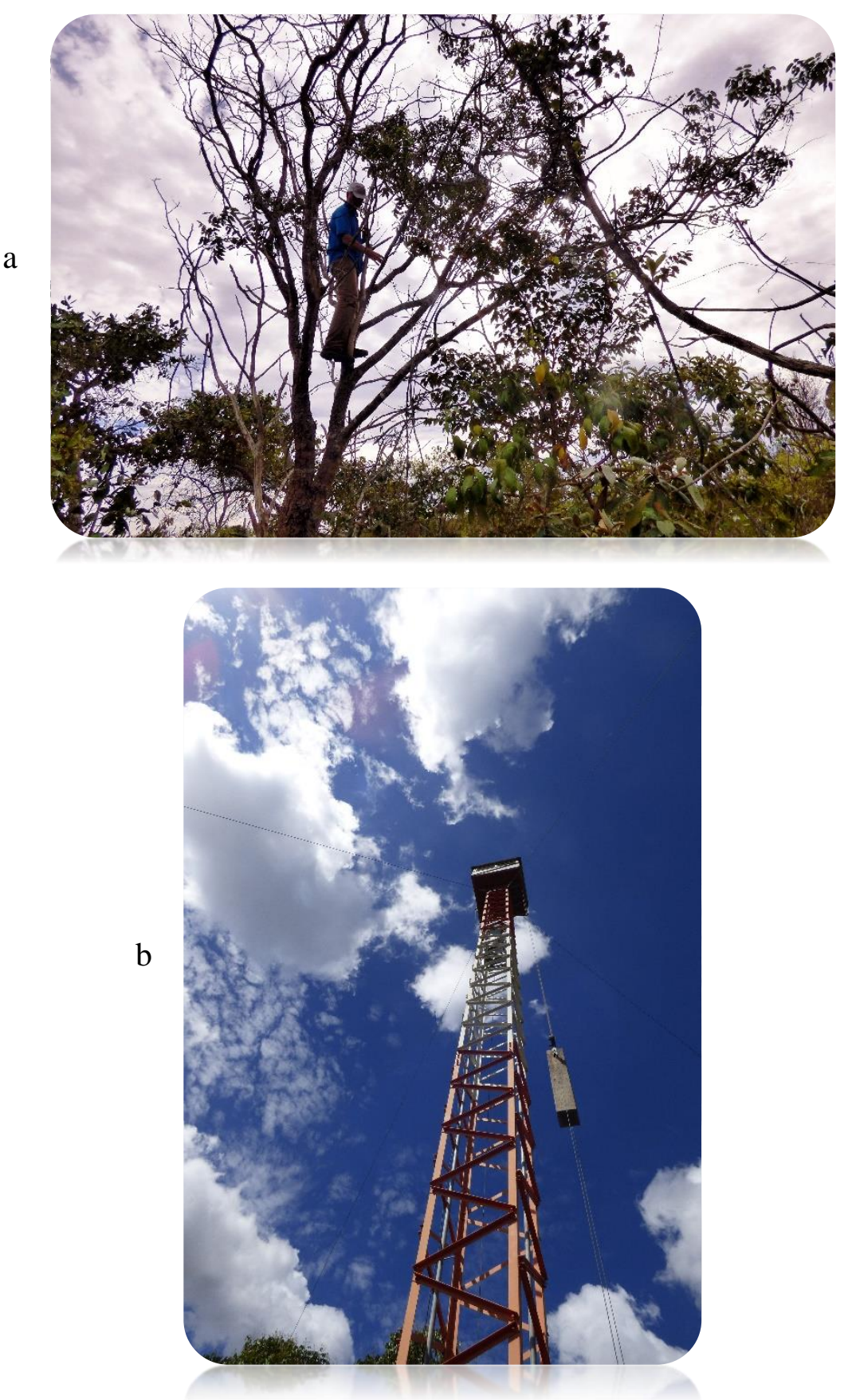

Figura 26 - Reconhecimento visual de feições hídricas em campo. a) Visão panorâmica proporcionada ao professor Eloi por escalada de carvoeiro do cerrado, ESEC-AE. b) Torre de Observação; ESEC-AE. Fonte: arquivo pessoal.

Todas as escalas oferecem limitações. Por esse motivo, a análise espacial deve ser integrativa, de maneira a fundamentar a determinação de feições hídricas em análises multiescalares, de acordo com a questão de proteção à qual a sua determinação seja aplicada. Moran (2011) fala em pesquisa multinível, em que as escalas são consideradas de maneira hierárquica, mas sem subordinação. Este conceito embasa a determinação de nascentes em escalas distintas conforme o objetivo (gestão de bacias hidrográficas, licenciamentos ambientais ou regularização de APP). 


\subsubsection{Levantamentos temporais: efemeridade, sazonalidade ou perenidade de}

surgências e acúmulos de água

As feições hídricas têm natureza dinâmica e sua determinação pode depender de análises temporais integradas às análises espaciais. O parâmetro temporal é imprescindível para a leitura do mapa e sua atualização (Silva Filho 2011). Segundo Santos (2004), a interpretação de fenômenos ao longo do tempo refere-se às questões de "o quê, onde, quando, quanto e por que" estão ocorrendo mudanças ambientais. Para a autora, as análises temporais baseiam-se na construção de cenários com interpretações sobre situações hipotéticas ou reais.

Cenários históricos podem ser elaborados para interpretações de cunho pedológico e de ecologia de paisagens, por exemplo, em ampla escala de tempo. A aplicação deste tipo de avaliação no estudo do processo de evolução das veredas é útil para a determinação do macrohabitat da área úmida e para a sua tipificação baseada na sucessão vegetacional natural (conforme discussão constante no Estudo de Caso na ESEC-AE, Capítulo 4). O que se deve destacar é a capacidade de retratar mudanças, seja na estrutura resultante da combinação dos elementos que compõe o meio, seja nas funções e interações entre esses elementos (Santos 2004). O mesmo se aplica à evolução de lagoas e à sua tendência de extinguir-se com o decorrer do tempo pelo processo de colmatação (também abordada no Estudo de Caso da ESEC-AE, Capítulo 4).

Já a análise de escala de tempo restrita aos cenários históricos antrópicos a partir de quando as intervenções começaram a se instalar nas feições hídricas, ou seja, em cenário relativamente recente é bastante útil na determinação de mudanças ambientais nas quais pode haver responsabilização do agente causador do impacto ambiental. Nesses casos o cenário histórico é investigativo e atribui causas aos impactos ambientais cumulativos no presente.

Em termos de temporalidade, outra questão proeminente diz respeito à efemeridade, sazonalidade ou perenidade de feições hídricas, o que é um ponto especialmente sensível na determinação de nascentes e olhos d'água.

A Lei 12.651/2012 não estabelece um parâmetro para o que é perene, sazonal ou efêmero, apesar de utilizar a perenidade como critério para a proteção de nascentes e de veredas (espaço permanentemente brejoso e encharcado) por meio de APPs. No entanto, o Decreto 7.830, de 17 de outubro de 2012, que dispõe sobre o Sistema de Cadastro Ambiental Rural, o Cadastro Ambiental Rural, estabelece normas de caráter geral aos Programas de Regularização Ambiental, de que trata a Lei no 12.651, de 25 de maio de 2012, direciona a interpretação de temporalidade ao definir o conceito de perene, intermitente e efêmero não para feições hídricas em geral, mas para rios especificamente (Art. $\left.2^{\circ}\right)$ :

Art. $2^{\circ}$ Para os efeitos deste Decreto entende-se por:

XII - rio perene - corpo de água lótico que possui naturalmente escoamento 
superficial durante todo o período do ano;

XIII - rio intermitente - corpo de água lótico que naturalmente não apresenta escoamento superficial por períodos do ano;

XIV - rio efêmero - corpo de água lótico que possui escoamento superficial apenas durante ou imediatamente após períodos de precipitação;

Para o caso de feições hídricas em geral, acredita-se que as definições poderiam ser aprimoradas de modo a abranger as particularidades de nascentes e áreas úmidas em geral, como veredas. Portanto, é pertinente refletir sobre as seguintes questões:

- Convencionar um tempo específico para perenidade, sazonalidade e efemeridade é favorável?

Se por um lado a falta de definição sobre os termos referentes à temporalidade das feições hídricas em geral pode ser prejudicial à aplicação da legislação ambiental e de sua devida proteção, por outro lado, arbitrar um tempo específico em dias, meses ou até mesmo ano pode ser atividade demasiadamente restritiva e inflexível a particularidades ambientais e climáticas.

Pondera-se, portanto, que utilizar o ciclo hídrico anual, analisado em séries históricas pluviométricas médias durante um período razoável de anos, seja recomendável. Por ciclo hídrico anual, entende-se nesta dissertação o período de um ano que compreende a configuração das feições hídricas durante as diferentes estações. No Brasil, de maneira geral, há bimodalidade pluviométrica (Cunha et al. 2015), ou seja, um período mais seco e outro mais chuvoso, à exceção da região sul em que as chuvas são mais bem distribuídas durante todo o ano. Assim, a análise com base no ciclo hídrico anual deve considerar a configuração da feição hídrica durante os períodos secos e chuvosos, em uma série histórica razoável, ou seja, modulada à escala temporal.

A partir da consideração do ciclo hídrico anual, analisado em séries históricas pluviométricas médias durante um período razoável de anos, acredita-se que a adoção dos seguintes parâmetros de efemeridade, sazonalidade ou efemeridade para a aplicação da lei sejam uma base simples, mas consistente de avaliação:

- Perene: a feição hídrica que apresente lâmina d'água por intervalo superior ao período chuvoso, com base em séries históricas pluviométricas.

- Sazonal: a feição hídrica que apresente lâmina d'água durante intervalo restrito ao período chuvoso, com base em séries históricas pluviométricas.

- Efêmero: feição hídrica de acúmulo de água por intervalo compreendido somente durante ou imediatamente após evento de precipitação.

As notáveis diferenças entre as definições para ambientes lóticos e as propostas nesta dissertação para feições hídricas em geral, portanto, consistem em não restringir a perenidade ao escoamento superficial, por não ser parâmetro aplicável a nascentes e áreas úmidas. Também não restringe a perenidade ao período exato de um ano, o que seria uma inflexibilidade desfavorável à 
complexidade dos contextos de nascentes e áreas úmidas no Brasil e ao padrão bimodal pluviométrico quase generalizado no território do país. Por outro lado, em primeira análise, não prejudicaria a definição de temporalidade na região sul, onde as chuvas são mais bem distribuídas ao longo do ano, caso em que pode-se aplicar a noção de período chuvoso à unimodalidade, ou seja, à unidade anual que já vem sendo utilizada na definição de temporalidade citada pelo Decreto 7.830/2012. Por fim, para a definição de efemeridade, a proposta é a substituição da expressão "períodos de precipitação", o que é impreciso, para "evento de precipitação". Dessa maneira, as feições hídricas efêmeras são aquelas em que apenas ocorre acúmulo de água durante ou imediatamente após uma chuva.

- Que práticas vêm sendo feitas em relação às análises temporais? Quais são as sugestões em relação a essas práticas?

Nas análises temporais de feições hídricas em geral, a tendência em trabalhos técnicos e científicos é a de adotar uma série histórica razoável, com o emprego de diferentes técnicas. A série histórica razoável, na prática, é aquela disponível em termos de registros e dados para uma determinada área. Não apenas de dados pluviométricos, como no parâmetro usado para a definição temporal proposta, mas também os dados de registro da configuração das feições hídricas no objeto de estudo. O fato é que a disponibilidade de dados é variável de área para área.

Por esse motivo, ressalta-se a importância do trabalho investigativo, com o emprego de diferentes ferramentas, conforme o grau de complexidade da análise. A sugestão é a de que, diante da eventual carência ou indisponibilidade de séries históricas razoáveis, se recorra a métodos complementares (como comentado no item 3.1.3 Produto: delineação espaço-temporal das feições) e a métodos de investigação de indícios de permanência temporal da lâmina d'água. Neste caso, o emprego do critério do grau de hidromorfismo do solo pode ser muito útil. A ocorrência de uma das categorias de solo com elevado grau de hidromorfismo é indício de permanência temporal de lâmina d'água ao menos sazonal, pelo fato de que os processos de hidromorfismo requerem tempo suficiente para se desenvolverem, o que descarta a possibilidade de acúmulo apenas efêmero. $\mathrm{O}$ caráter sazonal de permanência de lâmina d'água/encharcamento do solo é suficiente para que a feição seja reconhecida como área úmida e seja objeto de proteção adequada, conforme discutido no capítulo de revisão conceitual.

Assim, amarra-se a proposta metodológica de análise temporal à proposta de revisão conceitual desta dissertação que considera a ocorrência de solos com elevado grau de hidromorfismo como critério identificador de AUs. 


\subsubsection{Produto: cenários espaço-temporais}

Os cenários temporais de configuração espacial são os produtos da delineação espaçotemporal das feições hídricas. Cenários temporais frequentemente têm sido descritos e representados gráfica/cartograficamente. O emprego de SIG (Sistema de Informações Geográficas) é útil quando é possível registrar a ocorrência do fenômeno em determinado local ao longo do tempo por meio da comparação de séries de dados temporais (Santos 2004). Também são úteis registros históricos como fotos, relatos e vídeos. Em alguns casos, a datação de fenômenos é praticável.

$\mathrm{Na}$ análise qualitativa, a detecção de mudanças se dá pela sobreposição de imagens, fotografias em geral (inclusive as aéreas), mapas de diferentes datas e registros gráficos ou mesmo orais sobre as configurações da feição em questão em um determinado momento, nos quais ressaltam-se as diferenças que indicam as alterações ambientais.

$\mathrm{Na}$ análise quantitativa, datações de fenômenos podem ser estimadas por meio de métodos paleoambientais, como no caso das datações palinológicas, ou por meio de emprego de métodos geoquímicos, como a datação de água.

As técnicas de determinação espaço-temporal adequadas à necessidade de detalhamento do fenômeno (seja no contexto do CAR, do licenciamento ambiental, da gestão de bacias hidrográficas ou de UCs) embasam à caracterização de feições hídricas e por ela podem ser validadas e completadas (tópico 3.2). Este é o caso da determinação de AUs baseada no critério identificador de solos com elevado grau de hidromorfismo, que pode ser devidamente classificado conforme o Sistema Brasileiro de Classificação dos Solos - SiBCS (2013) na etapa de caracterização das feições hídricas. Neste nível de detalhamento, o critério identificador passa a ser um critério tipificador (tópico 3.2.1). Dessa forma, as etapas de determinação e de caracterização ficam amarradas de maneira integrativa e complementar.

\subsection{CARACTERIZaÇão DAS FEIÇõeS}

A etapa de caracterização consiste na descrição das feições hídricas baseada em levantamentos bibliográficos prévios, levantamentos de campo e compilação de dados multidisciplinares.

\subsubsection{Descrição das feições quanto aos critérios tipificadores por meio de levantamentos bibliográficos e de campo}

A caracterização das feições hídricas é corroborada por levantamentos bibliográficos que contextualizam a paisagem acerca de aspectos multidisciplinares. Como nascentes, veredas e áreas 
úmidas são ambientes de interface (terrestre/aquático), elementos dos meios que são por eles ligados podem estar presentes em gradientes que funcionam como bons indicadores de processos e de funções ambientais desempenhadas. Portanto, a análise é multidisciplinar e integrativa.

É comum partir da escala macro - regional - para uma escala micro - local, mas esta não é uma regra (item 3.1.1). No contexto regional, a consulta bibliográfica sobre aspectos como o bioma, a geomorfologia, o clima e alguns aspectos da hidrologia embasam a ideia geral sobre a configuração e dinâmica das feições hídricas em relação à paisagem com a qual se relacionam.

Os aspectos tipificadores em escala local referem-se às funções ambientais, ao relevo, vegetação, geologia, solos - com a importante classificação de solos com elevado grau de hidromorfismo para a identificação de áreas úmidas-e, por fim, hidrogeologia.

O detalhe da caracterização de feições hídricas varia conforme a necessidade da análise. A caracterização mais detalhada de feições hídricas de interface entre água subterrânea e solo/substrato rochoso (como nascentes e algumas classes de AUs) aplicável a licenciamentos ambientais (variável em grau de complexidade de acordo com o risco ambiental que o empreendimento ou atividade apresenta), a eventuais valorações de danos ambientais ou à elaboração de planos de manejo em UCs engloba múltiplos aspectos discutidos a seguir ou o detalhamento exaustivo de algum deles. Por outro lado, a caracterização expedita é mais aplicada em alguns casos de delimitação de APP para o CAR e estudos sobre temas específicos em trabalhos científicos podem dispensar ou simplificar a caracterização para atingir os objetivos.

A supressão de alguns dos aspectos listados a seguir e detalhamento de outros também pode ser modulada de acordo com o tipo de feição hídrica: a caracterização de nascentes pode se restringir apenas a questões hidrogeológicas e hidrológicas para a gestão de bacias, por exemplo. No caso das diversas categorias de áreas úmidas, a descrição dos critérios tipificadores abrange vários aspectos multidisciplinares como vegetação típica (principal critério de tipificação das AUs) e climatologia.

Os seguintes aspectos são considerados de maneira integrada para a tipificação de feições hídricas, ainda que o grau de análise e ênfase varie conforme a necessidade da abordagem:

- Bioma: No Brasil há seis biomas - Pantanal, Floresta Amazônica, Cerrado, Mata Atlântica, Caatinga e Pampa. Cada um deles, possui feições hídricas com características típicas em função das interações entre os meios físico, biótico e antrópico. A complexidade nas ocorrências de nascentes e áreas úmidas em geral é intimamente relacionada às riquezas de contextos e de macrohabitats dos biomas. A caracterização das feições hídricas fica melhor contextualizada com a inclusão do bioma nos modelos conceituais.

- Vegetação: a caracterização da vegetação pode ser muito útil para a compreensão de processos de transição no ambiente de interface terrestre/aquático e, consequentemente, para a elaboração de modelos conceituais de áreas úmidas. A distribuição de 
fitofisionomias e de organismos a elas associados é influenciada pela presença de água, embora a relação dos gradientes fitofisionômicos com a hidrogeologia seja complexa. O fenômeno da complexidade de distribuição vegetacional em áreas úmidas foi relatado por Bove et al. (2003) em estudo de caso de ecossistemas aquáticos temporários (brejo). No trabalho, os autores concluíram que espécies consideradas exclusivamente aquáticas foram encontradas em solo úmido, inclusive em floração, o que os levou a sugerir maior estudo sobre as espécies anfíbias. Em feições hídricas, a vegetação associada compreende não apenas as hidrófitas, mas as plantas que periodicamente estão submersas em diversos níveis ou as que margeiam estes ambientes, como as espécies anfíbias. Algumas espécies são sazonais e outras suportam a estiagem, mas têm população reduzida - o que altera a paisagem. Pott \& Pott (2000) consideram macrófitas/hidrófitas de maneira abrangente tanto como as plantas que vivem na água ou sobre a água, ou ainda, como plantas de margem que têm relação com água em abundância.

Além de caracterizar o fenômeno transicional entre ambientes aquáticos e terrestres (caso do gradiente de distribuição das macrófitas), a vegetação pode desempenhar o papel tipificador das áreas úmidas. Esse é o caso do buriti, que caracteriza as áreas úmidas reconhecidas como veredas, quando a distribuição das palmeiras é aproximadamente alinhada em alamedas ou renques, em meio a complexo vegetacional. A ocorrência de distribuição mais densa das palmeiras com formação de dossel é denominada como buritizal. Outras espécies tipificam categorias de áreas úmidas específicas, sejam elas campestres ou florestais.

- Geomorfologia: a compreensão sobre as formas do relevo e sua gênese tem forte influência sobre as a avaliação de tendências de acúmulo e distribuição da água no terreno. A dinâmica da água superficial e o relevo se influenciam mutuamente. A água se acumula, em geral, em locais planos, como em vales de fundo chato ou, eventualmente, em chapadas elevadas. Mas como a água é um agente de erosão, na escala de tempo geológico, a tendência é de que o curso exerça processo de erosão sobre o terreno e encaixe o talvegue.

Há diferentes modelos para explicar os processos de formação de relevos. Um exemplo disso, são superfícies planas residuais delimitadas por encostas com declividades variadas. Nascimento (2008) explica que há dois modelos dessas superfícies de aplainamento - denominadas chapadas: pediplanação e etchplanação. Segundo a autora

No modelo de pediplanação, rochas de diferentes resistências à erosão são truncadas por morfogênese mecânica (condições climáticas semiáridas) evoluindo, assim, para superfícies aplainadas. Mudanças climáticas para condições úmidas resultariam na 
dissecação da superfície plana por erosão diferencial, evoluindo para relevos dissecados. O retorno, posteriormente, de condições climáticas secas daria origem a uma a uma nova superfície de aplainamento em nível topográfico mais baixo, mantendo, entretanto, testemunhos da superfície mais antiga.

(...) Já a etchplanação é um modelo baseado em evolução de superfícies planas em condições climáticas com duas estações contrastantes e morfogênese geoquímica. Segundo Frakes, 1979, apud Martins, 2002, as condições climáticas reinantes no período de formação das superfícies planas eram úmidas e quentes, o que viria a favorecer o desenvolvimento de latossolos com formação de nível de couraças na zona de oscilação do lençol freático. A redução da umidade no ambiente, devido a alterações climáticas associadas a soerguimentos da crosta, propiciaria a denudação do latossolo e afloramento das couraças lateríticas que passariam a exercer controle sobre os processos erosivos desta superfície.

A caracterização da formação do relevo relacionados a feições hídricas são úteis para a compreensão de sua dinâmica de evolução e são úteis para embasar modelos conceituais de configuração de nascentes e AUs em geral.

\section{- Hidrologia}

A consideração de alguns aspectos hidrológicos pode ser útil à caracterização de feições hídricas, de acordo com o grau de detalhamento que análise exija. Entre esses aspectos, citam-se:

- Bacia hidrográfica: as informações sobre a Bacia Hidrográfica são muito úteis em termos de proteção de feições hídricas, pois o recorte espacial de análise de planejamento fundamenta-se em seus limites. De fato, os principais processos ecológicos e socioeconômicos são integrados pela água (Santos 2004).

- Disponibilidade hídrica: é a quantidade de água disponível para determinado uso, na qualidade necessária, em um trecho de corpo hídrico, durante determinado tempo. Este é um conceito importante para a proteção de nascentes, veredas e áreas úmidas, em função de permitir o planejamento de captação ou de derivação destas feições hídricas em consonância com o uso razoável do recurso.

- Eventuais conflitos de uso: o regime de recursos hídricos pode ser influenciado por atividades antrópicas e as interações com o meio ambiente. A fim de que o planejamento territorial seja elaborado para a proteção das feições hídricas a partir de áreas especialmente protegidas (APP de nascentes e de áreas úmidas e planejamento territorial a partir do inventário de áreas úmidas), é necessário que medidas de 
equacionamento do uso das terras e de eventuais conflitos faça parte da pauta prioritária das questões a serem resolvidas.

- Qualidade da água: Em muitos casos, a adoção de ferramentas adequadas para a proteção de feições hídricas depende de sua caracterização quanto à qualidade da água. Mais do que garantir a preservação da vegetação em APPs no entorno de feições hídricas, é necessário enfocar o bem que se pretende proteger: a água - ou seja, o recurso hídrico que viabiliza o ecossistema ao seu redor.

Em análises ambientais, com frequência, os padrões de referência adotados referem-se apenas às concentrações de substâncias acima das quais há riscos potenciais à saúde humana. Apesar disso, essa prática não é a mais adequada para a avaliação de alterações ambientais. O ideal é adoção de valores orientadores aplicáveis à avaliação de tendências de alteração ambiental qualitativa, capazes de identificar incrementos dos parâmetros em relação ao background. A razoabilidade deve orientar medidas de monitoramento das taxas de contaminantes, a mitigação ou a remediação dos impactos negativos e o controle ou a eliminação das fontes antes de causarem danos graves ao meio ambiente (Queiroz 2014). Os padrões normatizados para águas superficiais e subterrâneas são importantes referências e, se aplicados corretamente, podem ser eficientes instrumentos preventivos.

As nascentes, veredas e as categorias de AUs influenciadas por água subterrânea podem ser caracterizadas tanto em relação a padrões de qualidade de água subterrânea e do solo, estabelecidos respectivamente pela Resolução Conama 396, de 7 de abril de 2008 (Brasil 2008) e pela Resolução Conama 420, de 28 de dezembro de 2009 (Brasil 2009), quanto em relação aos padrões de enquadramento de águas superficiais, por meio da Resolução Conama 357, de 17 de março de 2005 (Brasil 2005), conforme o enfoque da análise em questão.

-Ciclo hidrológico e balanço hídrico: a proposta de elaboração de modelo conceitual como produto da determinação e caracterização de nascentes, veredas e áreas úmidas consiste basicamente na análise do ciclo hidrológico modulada à escala e ao detalhamento que a análise voltada à aplicação de instrumentos de proteção exija. O ciclo hidrológico usualmente é representado por bloco diagrama que considera as entradas e saídas de água do sistema (Figura 27). 


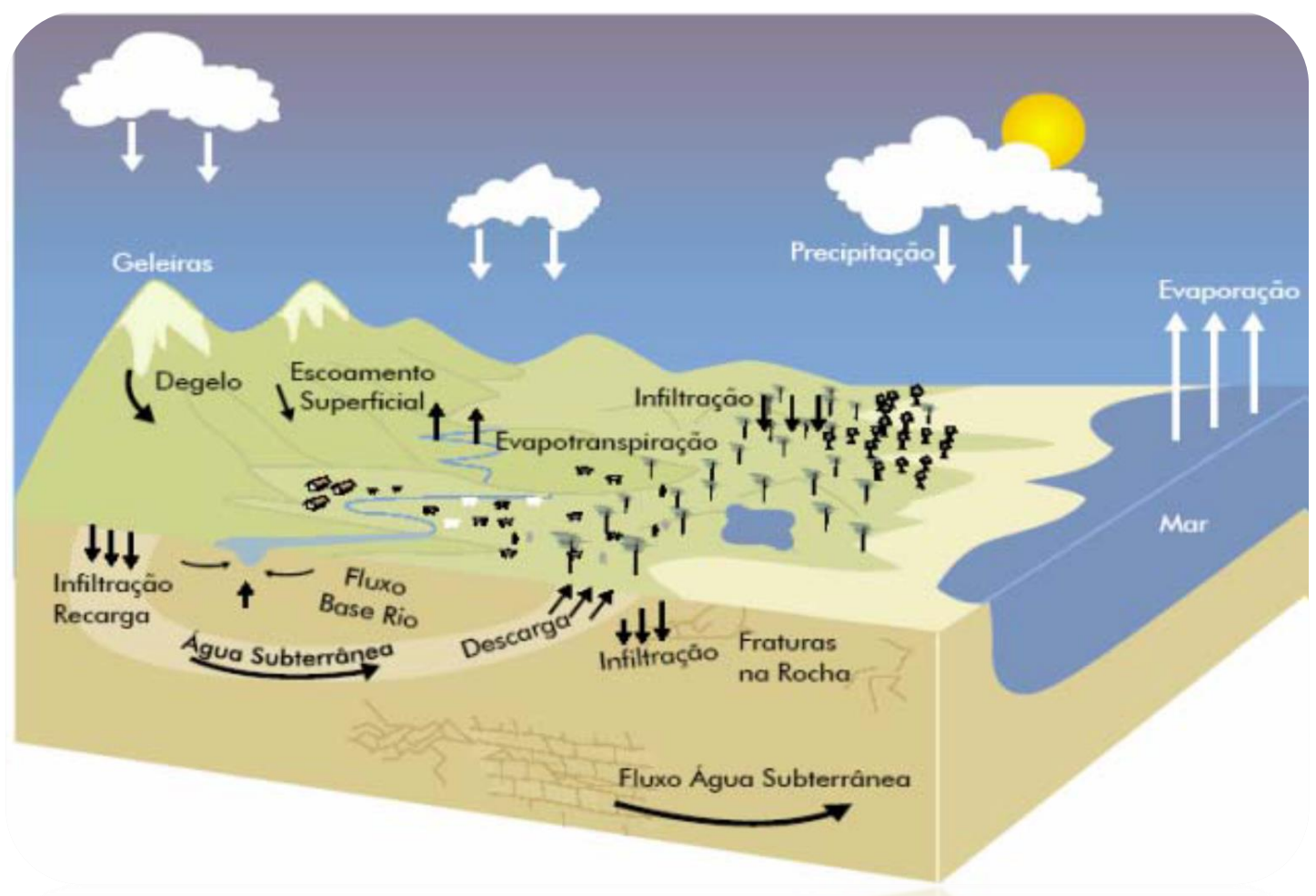

Figura 27 - Ciclo hidrológico. Disponível em: <http://www.mma.gov.br/agua/recursoshidricos/aguas-subterraneas/ciclo-hidrologico>. Acesso em: 23 nov. 2015.

O modelo conceitual do bloco diagrama é uma representação gráfica espacial dos processos do ciclo hídrico, sintetizados pela equação de balanço hídrico:

$$
[\mathrm{P}-\mathrm{R}-\mathrm{G}-\mathrm{E}-\mathrm{T}=\Delta \mathrm{S}]_{\mathrm{t}}
$$

Onde:

$\mathrm{P}=$ gradiente de precipitação

$\mathrm{R}=$ gradiente de escoamento superficial

$\mathrm{G}=$ gradiente de escoamento subterrâneo

$\mathrm{E}=$ gradiente de evaporação

$\mathrm{T}=$ gradiente de transpiração

$\Delta \mathrm{S}=$ gradiente de armazenamento

Essa equação nada mais é que mensuração da entrada (input) e da saída (output) de água no sistema. Assim, ela pode ser simplificada como:

$$
\mathrm{I}-\mathrm{O}=\mathrm{dS} / \mathrm{dt}
$$

Onde:

$\mathrm{I}=$ input (entrada de água no sistema)

$\mathrm{O}=$ output (saída de água no sistema)

A equação diferencial final é a forma básica da representação de qualquer sistema hidrológico e a aplicação da equação geral está condicionada à complexidade do problema estudado.

A modelagem de fenômenos pode ser matemática ou conceitual, conforme a questão a ser 
avaliada. A modelagem matemática exige coleta de dados com controle de qualidade para gerar produtos confiáveis. O levantamento, processamento e análise dos dados requer investimento de tempo e recursos financeiros (em equipamentos, logística e pessoal), que se justificam nos casos em que a quantificação do fenômeno analisado é fundamental, como no cálculo de vazões outorgáveis ou na valoração de danos ambientais em feições hídricas, por exemplo. Em boa parte dos casos, no entanto, a modelagem conceitual de feições hídricas é suficiente para a aplicação de instrumentos de proteção ambiental, como a delimitação de APP a partir da determinação e caracterização de nascentes e áreas úmidas para o CAR. Nesses casos, a entrada e saída de água do sistema não são precisamente quantificadas, mas o fenômeno analisado deve ser representado/descrito de maneira clara, coerente, concisa e permitir a associação direta com a realidade.

- Climatologia: as flutuações climáticas ao longo do tempo são determinantes na oscilação dos afloramentos de água subterrânea (nível da superfície potenciométrica ao longo de um ciclo hídrico anual, conforme discutido no tópico 2.5.1) e dos acúmulos de água superficial. A complexidade das variáveis climáticas (radiação solar, umidade, temperatura, pressão atmosférica, ventos e chuvas) exerce influência direta sobre o ciclo hidrológico entre os fatores de input e output de água no sistema (equação do balanço hídrico). O principal controle na avaliação de temporalidade de feições hídricas é a precipitação (conforme discutido no tópico 3.1.2). Na maior parte do Brasil, a distribuição de chuvas é bimodal e condiciona um período seco e outro mais chuvoso (Cunha et al. 2015). Portanto, a análise mais adequada de feições hídricas pode consistir em um modelo conceitual elaborado para um cenário temporal seco e outro chuvoso, a partir de informações sobre séries históricas pluviométricas razoáveis.

Em geral, a unidade do sistema considerado como base da avaliação de ciclo hidrológico é a bacia hidrográfica, mas para análises específicas, a escala de microbacia e, consequentemente, de microclima pode ser mais favorável à caracterização de feições hídricas para a geração do modelo conceitual.

- Funções ecossistêmicas: Segundo o Decreto 55.947, de 24 de junho de 2010, que regulamenta a Lei Estadual de São Paulo 13.798, de 9 de novembro de 2011, "as funções ecossistêmicas são os benefícios que as pessoas obtêm dos ecossistemas e serviços ambientais são serviços ecossistêmicos que têm impactos positivos além da área onde são gerados". Estes conceitos são fundamentais para se entender a importância da preservação de nascentes, veredas e áreas úmidas. Além de desempenharem importante papel ecossistêmico, na disponibilização do recurso hídrico para consumo dos organismos em geral, e dos seres humanos em especial, e para o desenvolvimento de interações entre as comunidades na natureza, as feições hídricas representam potencial de benefícios múltiplos. Essa é uma visão que integra o 
apelo econômico dos serviços ambientais com impactos positivos amplos.

Na caracterização das feições hídricas com vistas à sua proteção por instrumentos legais e técnicos integrados, pode ser essencial descrever e vislumbrar a importância que representam - diante da análise multidisciplinar integrada.

Sob o ponto de vista hidrogeológico, nascentes e algumas categorias de AUs são a interface entre o aquífero e a superfície. Portanto, são pontos de fragilidade à contaminação da água do reservatório subterrâneo. Em geral, aquíferos são protegidos da contaminação pela função de filtro/depuração que o solo representa. Mas nas áreas de interface direta entre os meios superficial e subterrâneo, a capacidade de filtragem do solo é reduzida. Inclusive, com base no próprio efeito tampão dos solos é possível assumir que se por um lado é mais difícil contaminar os aquíferos, por outro lado, uma vez já contaminados é ainda mais complexo descontaminá-los em comparação à rede hídrica superficial. As funções ecossistêmicas de nascentes e áreas úmidas em geral não se restringem à garantia da qualidade da água para o consumo humano quanto a aspectos econômicos e sociais, mas são integradas aos processos ambientais de maneira ampla. Sua caracterização detalhada para a elaboração de modelos conceituais pode justificar a proteção de áreas relevantes por instrumentos de zoneamento ambiental. Exemplos disso são os olhos d'água no semiárido, cuja relevância das funções ecossistêmicas deve ser considerada no Inventário Nacional de Áreas Úmidas como prioridade para a aplicação de instrumentos de proteção, em especial o zoneamento para o planejamento urbano.

- Geologia: a caracterização geológica - estudo da composição e da dinâmica da Terra - pode ser muito útil na compreensão das feições hídricas como componentes dinâmicos dos geossistemas (Sotchava 1978) e na elaboração de modelos conceituais. O substrato rochoso é simultaneamente condicionante e resultante da formação das paisagens. A partir da combinação dos litotipos (tipos de rochas) e da dinâmica do planeta, formam-se solos, relevos e estruturas nas rochas (como falhas e fraturas) que condicionam a distribuição da água na superfície, em subsuperfície e no sistema subterrâneo como um todo.

A água também interage com o sistema e o transforma, participando de vários processos geológicos, como a formação de minerais, precipitação de sais e concentração de minérios por hidrotermalismo, a lubrificação de processos estruturais, a preservação de fósseis em ambientes redutores, a potencialização de movimentos gravitacionais de massa, entre outros. Além disso, a qualidade da água é primordialmente influenciada pela composição química do substrato que a armazena e pelo qual ela flui. Entre tantos outros aspectos geológicos, a água é vista não apenas na perspectiva de recurso hídrico, como de recurso mineral, e a exploração de água de mineral das fontes brasileiras é 
regulamentada pelo Código de Águas Minerais (Brasil 1945).

Em geral, os principais aspectos geológicos para caracterização de feições hídricas são as estruturas que condicionam o fluxo da água e composição do substrato, com influências sobre a qualidade da água. A síntese dessas informações é abrangida por mapas geológicos, ferramenta de auxílio indicada para a elaboração de modelos conceituais.

-Hidrogeologia: no amplo campo de interações de processos geológicos e hidrológicos, a hidrogeologia enfoca principalmente a distribuição da água subterrânea e subsuperficial e as múltiplas aplicações de uso e gestão dos recursos hídricos subterrâneos. A hidrogeologia pode fundamentar os modelos conceituais mais detalhados (conforme a necessidade de análise) com informações sobre os parâmetros do aquífero, a partir dos conceitos de superfície potencial, recarga e descarga, nível de base, condutividade hidráulica, controles de ocorrência do afloramento de água à superfície, direções de fluxo, vazão do curso de água e, principalmente, parâmetros de qualidade da água (já discutidos no item sobre hidrologia). Em alguns casos, quando houver a necessidade de dirimir dúvidas a respeito das possíveis ferramentas de proteção para acúmulos de água de origem não determinada (pluviométrica ou subterrânea), sugere-se complementarmente a utilização de métodos isotópicos na avaliação ambiental hidrogeológica. Teoricamente, a relação de ${ }^{18} \mathrm{O} /{ }^{16} \mathrm{O}$ em comparação com a reta meteórica local pode ser um bom indicativo para análises ambientais. Ressalta-se que os instrumentos de proteção são diferentes para feições hídricas com maior contribuição de água de origem subterrânea (nascentes) e com maior contribuição de água de origem superficial (algumas categorias de áreas úmidas). Destaca-se que o entendimento de certas questões em relação às feições hídricas de interface entre água subterrânea e solos/substrato rochoso depende também da análise da Bacia Hidrogeológica, conceituada por Arraes (2008) como "o limite entre as zonas de recarga e descarga de um determinado aquífero, sendo a zona de recarga considerada a partir da região onde as águas ou plumas descendentes de umidade alcançam o topo da zona saturada dos aquíferos, e os exutórios os pontos ou áreas onde as águas retornam à superfície". A bacia hidrogeológica nem sempre coincide com os limites da bacia hidrológica, delimitada por divisores de águas topográficos. Essa avaliação pode ser útil nos modelos conceituais que envolvam a gestão de água subterrânea.

- Pedologia: o estudo dos solos contribui sobremaneira na elaboração de modelos conceituais a respeito de áreas úmidas das categorias submetidas a elevado grau de hidromorfismo e auxilia, complementarmente, na elaboração de modelos conceituais para nascentes. Como uma das propostas desta dissertação é a inserção das categorias de solo com elevado grau de hidromorfismo como critérios identificadores de AUs, 
maior enfoque é dado ao detalhamento deste item para a caracterização de feições hídricas.

Segundo a Sistema Brasileiro de Classificação dos Solos - SiBCS (2013) o solo é

Uma coleção de corpos naturais, constituídos por partes sólidas, líquidas e gasosas, tridimensionais, dinâmicos, formados por materiais minerais e orgânicos que ocupam a maior parte do manto superficial das extensões continentais do nosso planeta, contêm matéria viva e podem ser vegetados na natureza onde ocorrem e, eventualmente, terem sido modificados por interferências antrópicas.

Ou seja, por definição, a água é um dos componentes do solo. Nas situações em que há uma supersaturação de água no solo por um tempo prolongado, ele pode passar por processos que alteram suas características - hidromorfismo. Um exemplo é a transformação de $\mathrm{Fe}$-férrico em Fe-ferroso pelo processo de gleização, que confere ao solo cores acinzentadas, azuladas, esverdeadas ou neutras, eventualmente com mosqueados.

Contudo, a verificação de processo de gleização em perfil não é o único indicador de condições hidromórficas em um solo. Existem atributos diagnósticos que indicam a presença ou oscilação do nível potenciométrico no perfil como: a presença de plintita, petroplintita, além dos caráteres concrecionário, dúrico, plânico, plíntico, redóxico e outros atributos que, por si só não diferenciam as classes de solos (SiBCS 2013), mas que auxiliam na sua definição, como é o caso microrrelevo Gilgai. Gilgai é um critério baseado na taxonomia dos solos do Departamento de Agricultura dos EUA, que faz referência a microrrelevo típico de solos argilosos que têm um alto coeficiente de expansão com aumento no teor de umidade. Consiste em saliências convexas distribuídas em áreas quase planas ou configura feição topográfica de sucessão de pequenas depressões e elevações (Estados Unidos 1975 apud EMBRAPA 2013).

Os murundus, microrrelevo típico do cerrado, apresentam características muito semelhantes ao relevo Gilgai. Entretanto, ainda não constam entre os atributos indexados pelo SiBCS (EMBRAPA 2013). Talvez isso se deva à necessidade de aprofundar estudos quanto a essas feições e, se for o caso, fazer as devidas associações de atributos. No Distrito Federal, campos de Murundus são protegidos como APPs pela Instrução Normativa IBRAM 39 (Distrito Federal 2014), de 21 de fevereiro de 2014, que dispõe que:

Art. $2^{\circ}$ Entende-se por campos de murundus os microrrelevos formados por um conjunto de morrotes que se desenvolvem nas proximidades das 
cabeceiras e margens de drenagens.

$\S 1^{\circ}$ Os morrotes ou murundus são elevações arredondadas ou ovais com dimensões variadas, desde poucos centímetros a 2 metros e cujo diâmetro pode alcançar até 10 metros;

$\S 2^{\circ}$ Os campos de murundus são áreas onde ocorre, no período chuvoso, o afloramento natural do lençol freático;

$\S 3^{\circ}$ Os murundus são recobertos por vegetação de Cerrado e dependendo das dimensões do murundu, a cobertura vegetal pode ser de gramíneas, arbustos ou árvores;

$\S 4^{\circ}$ Nas áreas entre os murundus se desenvolve a vegetação de gramíneas.

A citada instrução estabelece regime especial para a proteção das APPs de murundus, como a manutenção de um raio mínimo de cinquenta metros de largura, em projeção horizontal:

Art. $3^{\circ}$ A supressão da vegetação e a utilização de áreas localizadas próximas a campos de murundus para drenagem, cultivo, pastoreio e outras atividades, devem atender as seguintes exigências:

I - manter um raio mínimo de proteção de 50 (cinquenta) metros de largura, em projeção horizontal, ao redor das áreas de campos de murundus, podendo esta distância ser ampliada, de acordo com as peculiaridades locais, a partir de parecer técnico emitido após vistoria em campo por técnicos do IBRAM;

II - obter autorização prévia do setor competente pela análise de pedidos de supressão no IBRAM;

III - quando se tratar de imóvel rural, apresentação prévia das Informações Ambientais de Imóvel Rural ao IBRAM.

Também prevê a recomposição de faixas marginais em áreas rurais consolidadas até 22 de julho de 2008:

Art. $4^{\circ}$ No caso de áreas rurais consolidadas até 22 de julho de 2008 em campos de murundu, será obrigatória a recomposição das faixas marginais, em projeção horizontal, delimitadas ao redor ao redor dos campos de murundu, de largura mínima de:

I - 30 (trinta) metros, para imóveis rurais com área de 4 (quatro) módulos fiscais; e

II - 50 (cinquenta) metros, para imóveis rurais com área superior a 4 (quatro) módulos fiscais.

Parágrafo único. Será considerada, para fins do disposto no caput e seus 
Na perspectiva das propostas desta dissertação, campos de murundus são considerados como macrohabitat da categoria de AUs de solos com elevado grau de hidromorfismo.

- Solos com elevado grau de hidromorfismo

O grau de hidromorfismo é condicionado pela eficiência com que a água infiltra-se e escoa pelo solo. A permanência da condição de encharcamento é função da classe de drenagem em que o solo se enquadra. Quanto menos drenado for o solo, mais elevado grau de hidromorfismo:

$\begin{aligned} & \text { EXCESSIVAMENTE } \\ & \text { ACENTUADAMENTE DRENADO } \rightarrow\end{aligned}$ BEM DRENADO $\rightarrow$ MORTEMENTE
DRENADO $\rightarrow$
DRENADO (mosqueado nos horizontes mais profundos) $\rightarrow$ IMPERFEITAMENTE
DRENADO (mosqueado ao longo do perfil e gleização nos horizontes mais profundos) $\rightarrow$
MAL DRENADO (frequente ocorrência de mosqueado e características de gleização no
perfil) $\rightarrow$ MUITO MAL DRENADO (comuns características de gleização elou acúmulo de
matéria orgânica, comumente com horizonte hístico).

Solos moderadamente e imperfeitamente drenados apresentam algum grau de hidromorfismo que se manifesta, respectivamente, como mosqueamento ou gleização em horizontes mais profundos. Solos mal drenados e muito mal drenados por tempo prolongado apresentam elevado grau de hidromorfismo. São comuns, nesses solos, características de gleização e/ou acúmulo, pelo menos superficial, de matéria orgânica, comumente com horizonte hístico.

Várias categorias de solos apresentam restrições à drenagem por algum atributo ou horizonte diagnóstico em seu processo de pedogênese. Das treze ordens de solos constantes no SiBCS (EMBRAPA 2013), sete podem apresentar algum grau de hidromorfismo (Figura 28): 


\begin{tabular}{|c|c|c|}
\hline Nomenclatura & Etimologia & Características associadas \\
\hline ARGISSOLOS & $\begin{array}{l}\text { Do latim argilla, conotando solos com processo de } \\
\text { acumulaçáo de argila. }\end{array}$ & Horizonte B textural \\
\hline CAMBISSOLOS & $\begin{array}{l}\text { Do latim cambiare, trocar; conotativo de solos em } \\
\text { formaçáo (transformaçáo). }\end{array}$ & Horizonte B incipiente \\
\hline CHERNOSSOLOS & $\begin{array}{l}\text { Do russo chern, negro; conotativo de solos ricos em } \\
\text { matéria orgânica, com coloraçáo escura. }\end{array}$ & $\begin{array}{l}\text { A chernozêmico. Preto, rico em } \\
\text { bases }\end{array}$ \\
\hline ESPODOSSOLOS & $\begin{array}{l}\text { Do grego spodos, cinza vegetal, solos com horizonte de } \\
\text { acumulaçáo de materiais orgânicos e outros. }\end{array}$ & Horizonte B espódico \\
\hline GLEISSOLOS & $\begin{array}{l}\text { Do russo gley, massa de solo pastosa; conotativo de } \\
\text { excesso de água. }\end{array}$ & Horizonte glei \\
\hline LATOSSOLOS & $\begin{array}{l}\text { Do latim lat, material altamente alterado (tijolo); } \\
\text { conotativo de elevado conteúdo de sesquióxidos. }\end{array}$ & Horizonte B latossólico \\
\hline LUVISSOLOS & $\begin{array}{l}\text { Do latim luere, lavar; conotativo de acumulaçáo de } \\
\text { argila. }\end{array}$ & $\begin{array}{l}\text { Saturado. Acumulaçáo de argila } \\
\text { Ta (alta atividade) }\end{array}$ \\
\hline NEOSSOLOS & $\begin{array}{l}\text { Do grego néos, novo, moderno; conotativo de solos } \\
\text { jovens, em início de formaçáo. }\end{array}$ & Pequeno desenvolvimento \\
\hline NITOSSOLOS & $\begin{array}{l}\text { Do latim nitidus, brilhante; conotativo de superfícies } \\
\text { brilhantes em unidades estruturais. }\end{array}$ & Horizonte B nítico \\
\hline ORGANOSSOLOS & $\begin{array}{l}\text { Do grego organikós, pertinente ou próprio dos } \\
\text { compostos de carbono. Conotativo de solos de constituiçáo } \\
\text { orgânica, ambientes de grande umidade. }\end{array}$ & Horizonte $\mathrm{H}$ ou $\mathrm{O}$ hístico \\
\hline PLANOSSOLOS & $\begin{array}{l}\text { Do latim planus, plano, horizontal; conotativo de solos } \\
\text { desenvolvidos com encharcamento superficial estacional. }\end{array}$ & Horizonte B plânico \\
\hline PLINTOSSOLOS & $\begin{array}{l}\text { Do grego plinthos, ladrilho; conotativo de materiais } \\
\text { argilosos, coloridos, que endurecem quando expostos. }\end{array}$ & Horizonte plíntico \\
\hline VERTISSOLOS & $\begin{array}{l}\text { Do latim vertere; conotativo de movimento na superfície } \\
\text { do solo (expansáo/contraçáo). }\end{array}$ & Horizonte vértico \\
\hline
\end{tabular}

Figura 28 - $1^{\circ}$ nível categórico do SiBCS - treze ordens de solos e suas características associadas. Entre elas, sete podem apresentar condições de hidromorfismo (realçadas em amarelo). Fonte: EMBRAPA (2013).

Ressalta-se que quatro dessas classes são diferenciadas por apresentarem elevado grau de hidromorfismo em seu estágio atual de evolução. Entre estas quatro classes, há duas cujo elevado grau de hidromorfismo é uma característica generalizada na ordem: Gleissolos e Organossolos. Ou seja, todos os Gleissolos e Organossolos são mal drenados a muito mal drenados e devem ser reconhecidos como critérios identificadores de AUs. Para as duas outras classes (Neossolos e Espodossolos), o elevado grau de hidromorfismo consta registrado no $3^{\circ}$ nível categórico (grandes grupos: Hidromórficos e Hidro-Hiperespessos), o que define sete grandes grupos a serem utilizados como critérios identificadores de AUs (um entre os Neossolos e seis entre os Espodossolos).

No primeiro nível categórico, os processos pedogenéticos são o critério de agrupamento das classes de solos com características comuns. No terceiro nível categórico, os níveis anteriores são separados por características, entre as quais a "presença de horizontes ou propriedades que restringem o desenvolvimento das raízes e afetam o livre movimento da água no solo". Com base nesses critérios relevantes, os solos com elevado grau de hidromorfismo que devem ser reconhecidos como critério identificador de AUs e, consequentemente, protegidos são relacionados a seguir: 
1) Gleissolos (Elevado grau de hidromorfismo: $\mathbf{1}^{\mathbf{0}}$ nível categórico - Ordem*):

*Toda a ordem do grupamentos de solos com expressiva gleização.

"Conceito - compreendem solos minerais, hidromórficos, que apresentam horizonte glei dentro de $50 \mathrm{~cm}$ a partir da superfície ou a profundidades entre $50 \mathrm{~cm}$ e $150 \mathrm{~cm}$ desde que imediatamente abaixo de horizontes A ou E (com ou sem gleização) ou de horizonte hístico com espessura insuficiente para definir a classe dos Organossolos. Não apresentam textura exclusivamente arenosa em todos os horizontes dentro dos primeiros $10 \mathrm{~cm}$ da superfície do solo ou até um contato lítico, tampouco horizonte vértico ou horizonte B plânico acima ou coincidente com horizonte glei ou qualquer outro tipo de horizonte B diagnóstico acima do horizonte glei. Horizonte plíntico, se presente, deve estar à profundidade superior a $200 \mathrm{~cm}$ da superfície do solo.

Observações adicionais - os solos desta classe encontram-se permanentemente ou periodicamente saturados por água, salvo se artificialmente drenados. A água permanece estagnada internamente ou a saturação ocorre por fluxo lateral no solo. Em qualquer circunstância, a água do solo pode se elevar por ascensão capilar, atingindo a superfície. (...) O processo de gleização implica a manifestação de cores acinzentadas, azuladas ou esverdeadas devido à redução e solubilização do ferro, permitindo a expressão das cores neutras dos minerais de argila ou ainda a precipitação de compostos ferrosos. (...) São solos que ocasionalmente podem ter textura arenosa (areia ou areia franca) somente nos horizontes superficiais, desde que seguidos de horizonte glei de textura francoarenosa ou mais fina. (...) esses solos podem apresentar horizonte sulfúrico, cálcico, propriedade solódica, sódica, caráter sálico ou plintita em quantidade ou posição não diagnóstica para enquadramento na classe dos Plintossolos. São solos formados principalmente a partir de sedimentos, estratificados ou não, e sujeitos a constante ou periódico excesso d'água, o que pode ocorrer em diversas situações. Comumente, desenvolvem-se em sedimentos recentes nas proximidades dos cursos d'água e em materiais colúvio-aluviais sujeitos a condições de hidromorfia, podendo formar-se também em áreas de relevo plano de terraços fluviais, lacustres ou marinhos, como também em materiais residuais em áreas abaciadas e depressões. São eventualmente formados em áreas inclinadas sob a influência do afloramento de água subterrânea (surgentes). São solos que ocorrem sob vegetação hidrófila ou higrófila herbácea, arbustiva ou arbórea.

Abrangência: esta classe abrange os solos que foram classificados anteriormente como Glei Pouco Húmico, Glei Húmico, parte do Hidromórfico Cinzento (sem mudança textural abrupta), Glei tiomórfico e Solonchak com horizonte glei” (EMBRAPA 2013).

2) Organossolos (Elevado grau de hidromorfismo: $1^{\circ}$ nível categórico - Ordem*):

*Toda a ordem do grupamento de solos orgânicos.

"Conceito - compreendem solos pouco evoluídos, com preponderância de características devidas ao material orgânico, de coloração preta, cinzenta muito escura ou brunada, resultantes de acumulação de resíduos vegetais, em graus variáveis de decomposição, em condições de drenagem restrita (ambientes mal a muito mal drenados) ou em ambientes úmidos e frios de altitudes elevadas, saturados com água por apenas poucos dias durante o período chuvoso.

Observações adicionais - estes solos são formados de material orgânico em locais cujo clima varia desde tropical e com hidromorfia, na região costeira e em deltas e 
ambientes lacustres, até frio e úmido e com vegetação alto-montana. Podem apresentar horizonte hístico formado em condições que favorecem a anaerobiose (horizonte $\mathrm{H}$ ) ou ser de drenagem livre (horizonte $\mathrm{O}$ ). $\mathrm{O}$ material de origem desses solos é composto por resíduos vegetais em vários estágios de decomposição, geralmente em mistura com materiais minerais de granulometria variável.

Em ambientes sujeitos a forte hidromorfismo, pelo fato de o lençol freático permanecer elevado durante grande parte do ano, as condições anaeróbicas restringem os processos de mineralização da matéria orgânica e limitam o desenvolvimento pedogenético, conduzindo à acumulação expressiva de restos vegetais.

Em ambientes de clima úmido, frio e de vegetação alto-montana, as condições de baixa temperatura favorecem o acúmulo de material orgânico pela redução da atividade biológica. Nesses ambientes, as condições de distrofismo e elevada acidez podem também restringir a transformação da matéria orgânica. (...)

A mineralização da matéria orgânica e a transformação dos resíduos vegetais são lentas em condições naturais. No entanto, a drenagem desses solos para fins agrícolas ou outros conduz ao processo de subsidência e acelera a decomposição da matéria orgânica, promovendo a sua degradação. A composição do material vegetal, a espessura dos materiais orgânicos depositados, as condições de clima e hidromorfismo e a intensidade de manejo - drenagem, calagem e adubação determinam a intensidade de degradação dos Organossolos.

Ocorrem normalmente em áreas baixas de várzeas, depressões e locais de surgentes, sob vegetação hidrófila ou higrófila, quer do tipo campestre, quer do florestal. Ocorrem também em áreas que estão saturadas com água por poucos dias (menos de 30 dias consecutivos) no período das chuvas situadas em regiões de altitudes elevadas, de clima úmido, frio e de vegetação alto-montana, neste caso, estando normalmente assentes diretamente sobre rochas não fraturadas, horizonte $\mathrm{C}$ ou ainda horizonte B pouco desenvolvido.

Abrangência: nesta classe estão incluídos os Solos Orgânicos, Semiorgânicos, Solos Tiomórficos de constituição orgânica ou semiorgânica e parte dos Solos Litólicos com horizonte O hístico com $20 \mathrm{~cm}$ ou mais de espessura". (EMBRAPA 2013).

3) Neossolos (Elevado grau de hidromorfismo: $3^{\circ}$ nível categórico - grande grupo*: Neossolos Quartzarênicos Hidromórficos):

*Um grande grupo dentro do grupamento de solos pouco evoluídos, sem horizonte B diagnóstico definido.

Conceito - solos com a presença de lençol freático elevado durante grande parte do ano, na maioria dos anos, imperfeitamente ou mal drenados e apresentando um ou mais dos seguintes requisitos:

a) Horizonte $\mathrm{H}$ hístico; e/ou

b) Saturação com água permanente dentro de $50 \mathrm{~cm}$ da superfície do solo; e/ou

c) Presença de lençol freático dentro de $150 \mathrm{~cm}$ da superfície do solo durante a época seca; e/ou

d) Presença de lençol freático dentro de $50 \mathrm{~cm}$ de profundidade, durante algum tempo, na maioria dos anos, a menos que artificialmente drenados, e satisfazendo a um ou mais dos seguintes requisitos:

1) Croma zero; 
2) Matiz 10YR ou mais vermelho com valor (cor úmida) de 4 ou maior e croma 1 ;

3) Matiz 2,5 Y ou mais amarelo, com croma 3 ou menor e mosqueado (ou com áreas de acumulação de ferro e/ ou manganês;

4) Matiz 2,5 Y ou mais amarelo e croma 1 ou menor;

5) Matizes 5GY, 5G, 5BG ou 5B; e/ou

e) Presença de ferro reduzido em quantidade capaz de desenvolver uma cor vermelha intensa, com o emprego do indicador químico alfa, alfa-dipiridil (CHILDS, 1981)" (EMBRAPA 2013).

4) Espodossolos (Elevado grau de hidromorfismo: $3^{\circ}$ nível categórico - grandes grupos*:

-Espodossolos Humilúvicos Hidro-Hiperespessos

-Espodossolos Humilúvicos Hidromórficos;

-Espodossolos Ferrilúvicos Hidro-Hiperespessos;

-Espodossolos Ferrilúvicos Hidromórficos;

-Espodossolos Ferri-Humilúvicos Hidro-Hiperespessos; e

-Espodossolos Ferri-Humilúvicos Hidromórficos)

* Seis grandes grupos dentro do grupamento de solos com B espódico.

"Conceito - compreendem solos constituídos por material mineral com horizonte B espódico subjacente a horizonte eluvial E (álbico ou não), a horizonte A, que pode ser de qualquer tipo, ou ainda a horizonte hístico com espessura insuficiente para definir a classe dos Organossolos. Esses solos apresentam, usualmente, sequência de horizontes A, E, B espódico, C, com nítida diferenciação de horizontes.

Critério - desenvolvimento de horizonte diagnóstico B espódico em sequência a horizonte E (álbico ou não), A ou hístico.

Observações adicionais - são desenvolvidos principalmente de materiais arenoquartzosos sob condições de umidade elevada, em clima tropical e subtropical, em relevo plano, suave, ondulado, áreas de surgência, abaciamentos e depressões, podendo, entretanto, ocorrer em relevo mais acidentado, em ambientes de clima frio, úmido e de vegetação alto-montana (Dias et al. 2003). Nas regiões costeiras, em geral, estão associados à vegetação genericamente denominada de Restinga. Os Espodossolos que ocorrem na Amazônia e nos Tabuleiros Costeiros frequentemente estão associados a vegetações conhecidas como Campinarana e Muçununga, respectivamente.

Abrangência: nesta classe, estão incluídos todos os solos que foram classificados anteriormente como Podzol e Podzol Hidromórfico" (EMBRAPA 2013).

Interessante notar que alguns macrohabitats de AUs são citados entre as informações adicionais sobre as classes de solos com elevado grau de hidromorfismo do SiBCS (EMBRAPA 2013). Segundo as observações adicionais, Gleissolos comumente desenvolvemse em sedimentos recentes nas proximidades dos cursos d'água e em materiais colúvio-aluviais sujeitos a condições de hidromorfia, podendo formar-se também em áreas de relevo plano de terraços fluviais, lacustres ou marinhos e em materiais residuais em áreas abaciadas e 
depressões. São eventualmente formados em áreas inclinadas sob a influência do afloramento de água subterrânea (surgentes) e ocorrem sob vegetação hidrófila ou higrófila herbácea, arbustiva ou arbórea. Organossolos são associados a várzeas e locais cujo clima varia desde tropical e com hidromorfia, na região costeira e em deltas e ambientes lacustres, até frio e úmido e com vegetação alto-montanas. Espodossolos são associados a ocorrências de Restingas, Campinaranas e Muçunungas ${ }^{8}$. Ferreira (2005) descreveu o substrato associado a manguezais e destacou que não são simplesmente sedimentos, mas são solos com elevado grau de hidromorfismo e com vários processos pedogenéticos associados.

São quatro os principais condicionantes para que o solo apresente elevado grau de hidromorfismo (Figuras 29 a 32).

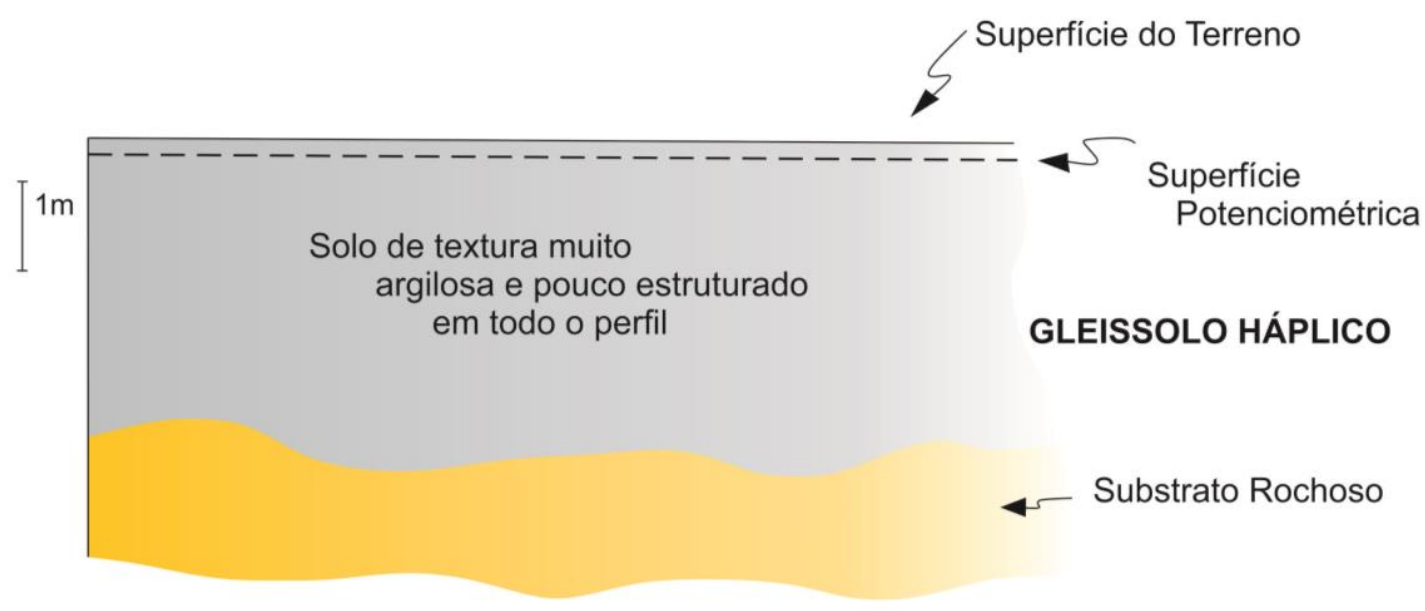

Figura 29 - Gleissolo. Condicionante: solo de textura muito argilosa e pouco estruturado em todo o perfil.

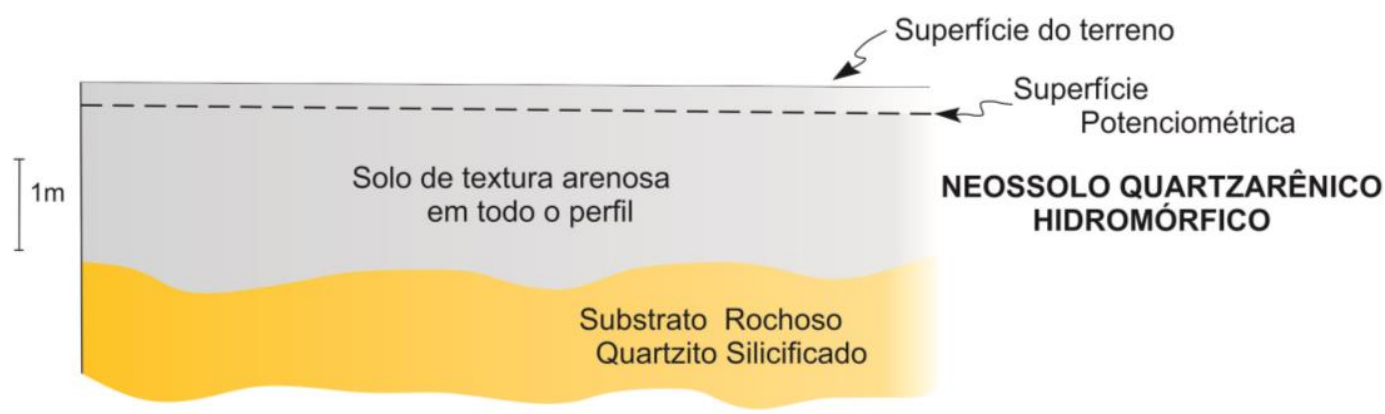

Figura 30 - Neossolo Quartzarênico Hidromórfico. Condicionante: solo de textura arenosa em todo o perfil limitado por substrato rochoso - quartzito silicificado.

\footnotetext{
${ }^{8}$ Muçunungas: constituem enclaves de vegetação savânica e florestal inseridos em áreas peculiares dos Tabuleiros Costeiros, onde processos pedogenéticos resultaram em arenização do solo (Sarcinelli 2010).
} 


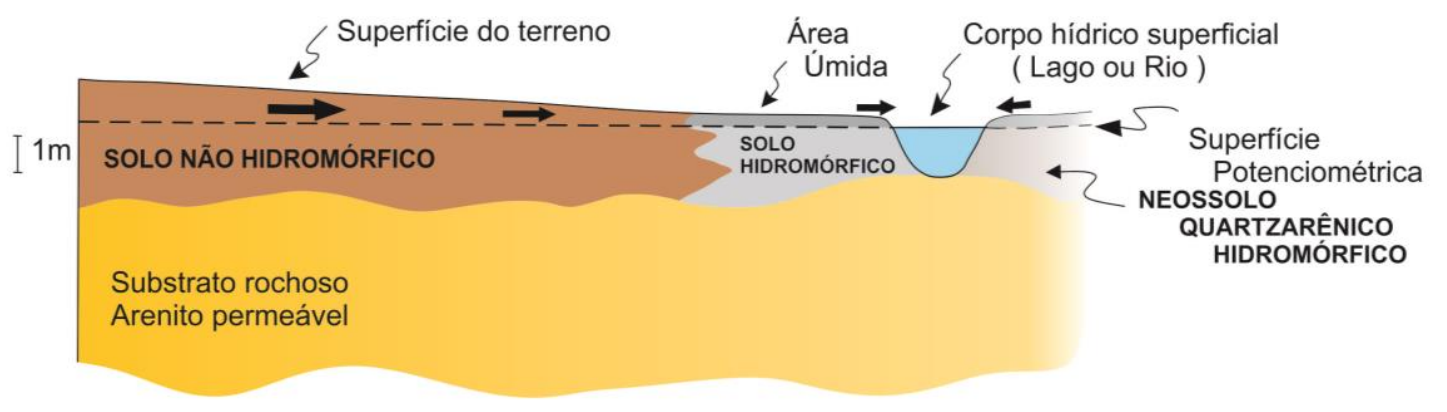

Figura 31 - Neossolo Quartzarênico Hidromórfico. Condicionante: input maior que output.

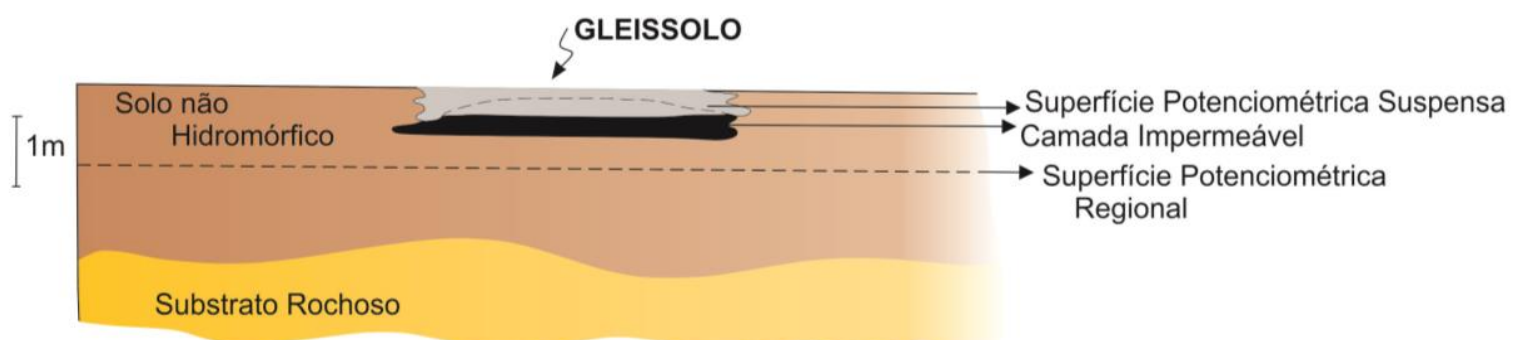

Figura 32 - Gleissolo. Condicionante: superfície potenciométrica suspensa por camada impermeável sobre superfície potenciométrica regional.

Ainda sobre o tema de pedologia relacionada à caracterização de feições hídricas, cabe esclarecer que as demais classes de solos que podem apresentar algum grau de hidromorfismo (Cambissolos, Planossolos e Plintossolos), apresentam o horizonte glei em profundidade não diagnóstica para Gleissolo. Essa característica é representada no $4^{\circ}$ nível categórico pela designação "gleissólico" e indica atributo que define esses solos como intermediários para outras classes. Portanto, Cambissolos, Planossolos e Plintossolos não se enquadram como AUs com solos de elevado grau de hidromorfismo típicas.

Da amarração de proposta de revisão conceitual com a proposta metodológica, conclui-se que se o solo for classificado dentro das categorias de solo com elevado grau de hidromorfismo deverá ser considerado como área úmida. Se o solo for um Paleogleissolo ou apenas apresentar variações do lençol freático, determináveis pelos níveis lateríticos, então não deverá mais ser considerado área úmida no presente.

\subsubsection{Produto: modelos conceituais}

Os modelos conceituais aqui propostos são o produto da integração entre os métodos de determinação espaço-temporal e de caracterização das feições hídricas em questão. A ideia é de que eles não sejam simplesmente concebidos como representações gráficas, mas como um 
conjunto de ferramentas que permitam a interpretação do fenômeno e de seus processos associados para a aplicação adequada dos instrumentos de proteção. Compõem essas ferramentas de análise:

-Mapas;

-Perfis;

-Fotografias;

-Blocos diagrama;

-Tabelas;

-Quadros comparativos;

-Relatório descritivo associado.

O emprego desses recursos deve ser adequado ao objetivo ao qual o estudo se propõe. As escalas de análise, de levantamento e de representação gráfica são moduladas para responder às questões em caso de avaliações de nascentes, veredas e áreas úmidas para a aplicação de diferentes instrumentos de proteção. O estudo de caso na ESEC-AE (capítulo 4) propõe a aplicação dos métodos discutidos neste capítulo. 


\section{CAPÍTULO 4}

\section{ESTUDO DE CASO: ESTAÇÃO ECOLÓGICA DE ÁGUAS EMENDADAS - ESEC-AE}

A aplicação da proposta metodológica para a caracterização de nascentes, veredas e áreas úmidas ocorreu na Estação Ecológica de Águas Emendadas - ESEC-AE, que se insere em uma configuração hidrológica de grande relevância em termos de feições hídricas, em interface entre o sistema hidrogeológico (Província Hidrogeológica Escudo Central) e a rede hidrológica superficial (Bacia do Tocantins e Bacia do Paraná).

A ESEC-AE é uma área particularmente favorável para a realização de pesquisas, por ser uma Unidade de Conservação - UC com a vocação de acolher cientistas, professores e estudantes para o desenvolvimento de pesquisas. Estações Ecológicas, categoria de Unidade de Conservação de Uso Integral, foram criadas com o intuito de funcionarem como um laboratório em campo. O nome "estação" foi concebido como referência às estações espaciais, nas quais os astronautas realizam experimentos para esclarecer os fenômenos e processos em local sob condições experimentais especiais (Horowitz \& Jesus in Seduma 2008). Uma analogia pode ser realizada com a ESEC-AE, com condições de laboratório na natureza para pesquisas multidisciplinares.

Outro ponto positivo é a proximidade da Estação à Brasília, com consequente facilidade de acesso, riqueza de referências multidisciplinares produzidas por centros de estudo e pesquisa da capital, condições de trabalho garantidas por equipe de apoio e possibilidade de realização dos levantamentos por período prolongado. Além disso, a proximidade a centros urbanos também proporciona questões sobre desafios reais de equacionamento de uso de recursos hídricos por população historicamente presente no entorno há séculos, em expansão territorial crescente, e a conservação dos recursos hídricos para as atuais e futuras gerações.

O IBRAM, órgão ambiental do DF responsável pela gestão da ESEC-AE, vem incentivando estudos na área com o objetivo de esclarecer se as áreas úmidas, em especial as veredas, estão em processo de redução dimensional progressivo. Esta dissertação busca acrescentar elementos às ricas discussões já desenvolvidas na área, integrando os conceitos propostos com a compilação de estudos realizados em termos de levantamentos espaciais, temporais e levantamentos de campo na determinação e caracterização das feições hídricas presentes na área. Assim, emprega as propostas conceituais e metodológicas desenvolvidas nos capítulos 2 e 3 deste trabalho, adaptadas às necessidades locais, para sintetizar considerações sobre a dinâmica das feições hídricas na UC.

\subsection{DETERMINAÇão DAS FEIÇõES}

Os esforços deste estudo de caso são direcionados para a elaboração de modelos 
conceituais de nascentes e áreas úmidas e para o conhecimento de sua dinâmica, com o reconhecimento de algumas de AUs de pequenas dimensões pela presença de solos com elevado grau de hidromorfismo (entre os quais as veredas e os demais macrohabitats como campos úmidos, matas alagadas, campos de murundus, campos limpos, cabeceiras de cursos d'água com nascentes e olhos d'água relacionados a solo com elevado grau de hidromorfismo). Cabe esclarecer que este estudo não visa o mapeamento das feições hídricas da área. Estes já existem e são aqui citados.

Os processos que vem se desenvolvendo na ESEC-AE apresentam indícios biogeográficos, palinológicos, climáticos e geomorfológicos de redução e expansão de áreas úmidas relacionadas a ciclos naturais. Contudo, deve-se considerar que as intervenções humanas na ESEC-AE e em seu entorno podem potencializar a velocidade com que se os processos se desenvolvem e alterar a dinâmica de disponibilidade hídrica e de biodiversidade a ela associada.

Assim, a abordagem dos modelos conceituais é adaptada de maneira a oferecer contribuições quanto à principal questão que tem sido levantada em relação ao reconhecimento das feições hídricas como fenômenos no espaço e no tempo: as AUs, em especial as veredas, estão diminuindo com o tempo? Como protegê-las?

\subsubsection{Levantamentos espaciais}

A ESEC-AE situa-se no nordeste do Distrito Federal, ao norte da Região Administrativa de Planaltina - R.A. VI (Figura 33). Localiza-se a aproximadamente $50 \mathrm{~km}$ do centro de Brasília e a $5 \mathrm{~km}$ do centro de Planaltina, em uma área total oficialmente divulgada de $10.547,21$ ha (Carvalho in SEDUMA 2008).

\section{- Materiais e métodos}

O estudo de caso sobre a aplicação de métodos de determinação e classificação de nascentes, veredas e áreas úmidas na ESEC-AE envolveu a aplicação de ferramentas de SIG com escala inicialmente geral, com recorte dos limites da UC, para o reconhecimento de diferentes classes de feições hídricas representativas de nascentes, identificadas por áreas de cabeceira (relevo em anfiteatro ou estimativa de origem de linhas de drenagem no terreno) e de categorias de áreas úmidas por indícios de solos com elevado grau de hidromorfismo (entre as quais as veredas, os campos úmidos, campos limpos, os campos de murundus, as matas alagadas e a transição entre veredas e matas de galeria). 


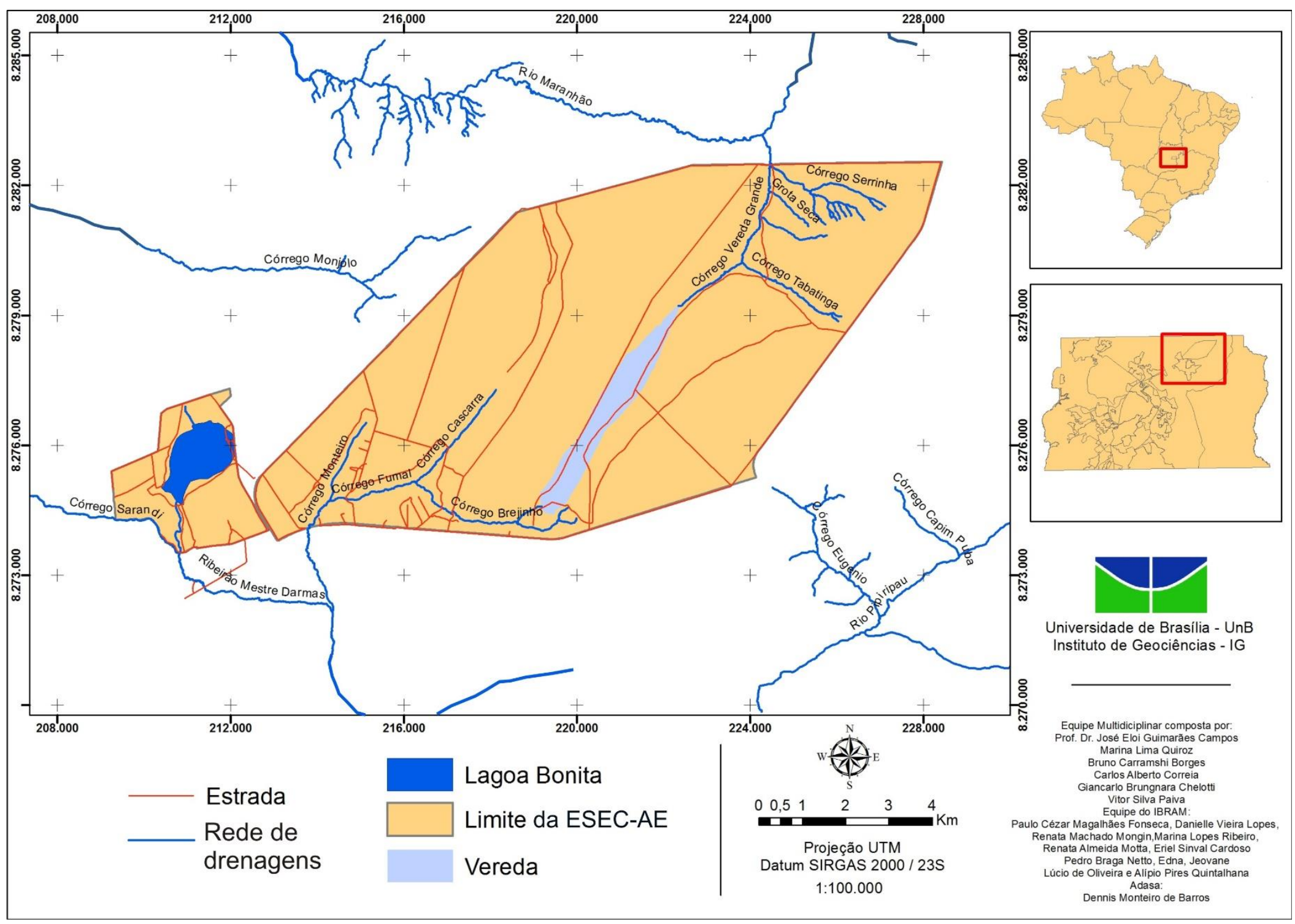

Figura 33 - Mapa de localização da ESEC-AE. A UC situa-se na Região Centro-Oeste do Brasil, na porção nordeste do Distrito Federal. As principais referências espaciais para o levantamento na área são as vias de acesso e a rede hidrográfica. 
A escala de levantamento delineou-se a partir das estradas de acesso que intersectam a UC. Para definir os pontos a serem visitados em malha representativa, utilizou-se SIG com base na série histórica de fotografias aéreas digitais ULTRACAM-X cedidas pela Terracap ${ }^{9}$ para o polígono da ESEC-AE e entorno. Ainda que diante de um catálogo variado, muitas das imagens não tinham cobertura da UC completa. A equipe ${ }^{10}$ realizou processamento ${ }^{11}$ das fotos aéreas digitais mais favoráveis à visualização do contexto integral e selecionou polígonos com resposta espectral potencialmente correspondente a áreas úmidas para que fossem validados em campo (Figura 34).

Equipe do Ibram $^{12}$ foi consultada quanto ao contexto e em seguidas ocasiões diferentes servidores acompanharam ou conduziram os trabalhos de campo. A campanha de coletas de dados consistiu em dez saídas de campo à ESEC-AE e arredores distribuídas entre os meses de maio e agosto de 2015, com equipes multidisciplinares que subsidiaram a elaboração de modelo conceitual integrado. Na campanha de visitas aos polígonos selecionados como representantes em potencial de áreas úmidas, validaram-se os padrões de respostas espectrais para trabalho de mapeamento e de cálculo da área de AUs. Já o levantamento de surgências representativas para elaboração de distintos modelos conceituais foi feita com base nos pontos de monitoramento realizado pelo IBRAM, dentro do Projeto denominado "Adote uma Nascente".

Seis feições selecionadas pela representatividade: 1. Nascente de fratura (ponto 12); 2. Vereda (pontos 5, 6, 22, 32, 45, 50, 51; 52, 64 e 65); 3. Cabeceira - contexto de AU $\rightarrow$ elevado grau de hidromorfismo; diversos olhos d'água e nascente (pontos 41 a 43); 4. Olho d'água condicionado por contato entre unidades geológicas (ponto 30); 5. Campo de Murundus (pontos 8 e 56); Lagoa Bonita (ponto 35).

\footnotetext{
${ }^{9}$ Por intermédio do servidor Vitor Hugo Santos da Silva.

${ }^{10}$ Equipe multidisciplinar composta por geólogos (Prof. Dr. José Eloi Guimarães Campos e a subscritora desta dissertação); agrônomo (Bruno Carramshi Borges); biólogo (Carlos Alberto Correia); engenheiro florestal (Giancarlo Brugnara Chelotti). O responsável pelo processamento de imagens foi Bruno Carramshi Borges. A validação de campo foi conjunta.

${ }^{11}$ As fotografias aéreas digitais pancromáticas foram classificadas de acordo com índices espectrais no Software Envi por Bruno Carramshi Borges, com base em BORGES et al. (2014).

${ }^{12}$ Equipe do Ibram: Paulo César Magalhães Fonseca, Danielle Vieira Lopes, Renata Machado Mongin, Marina Lopes Ribeiro, Renata Almeida Motta, Eriel Sinval Cardoso, Pedro Braga Netto, Edna, Jeovane Lúcio de Oliveira e Alípio Pires Quintanilha. Acompanhamento do Servidor da Adasa Dennis Monteiro de Barros.
} 


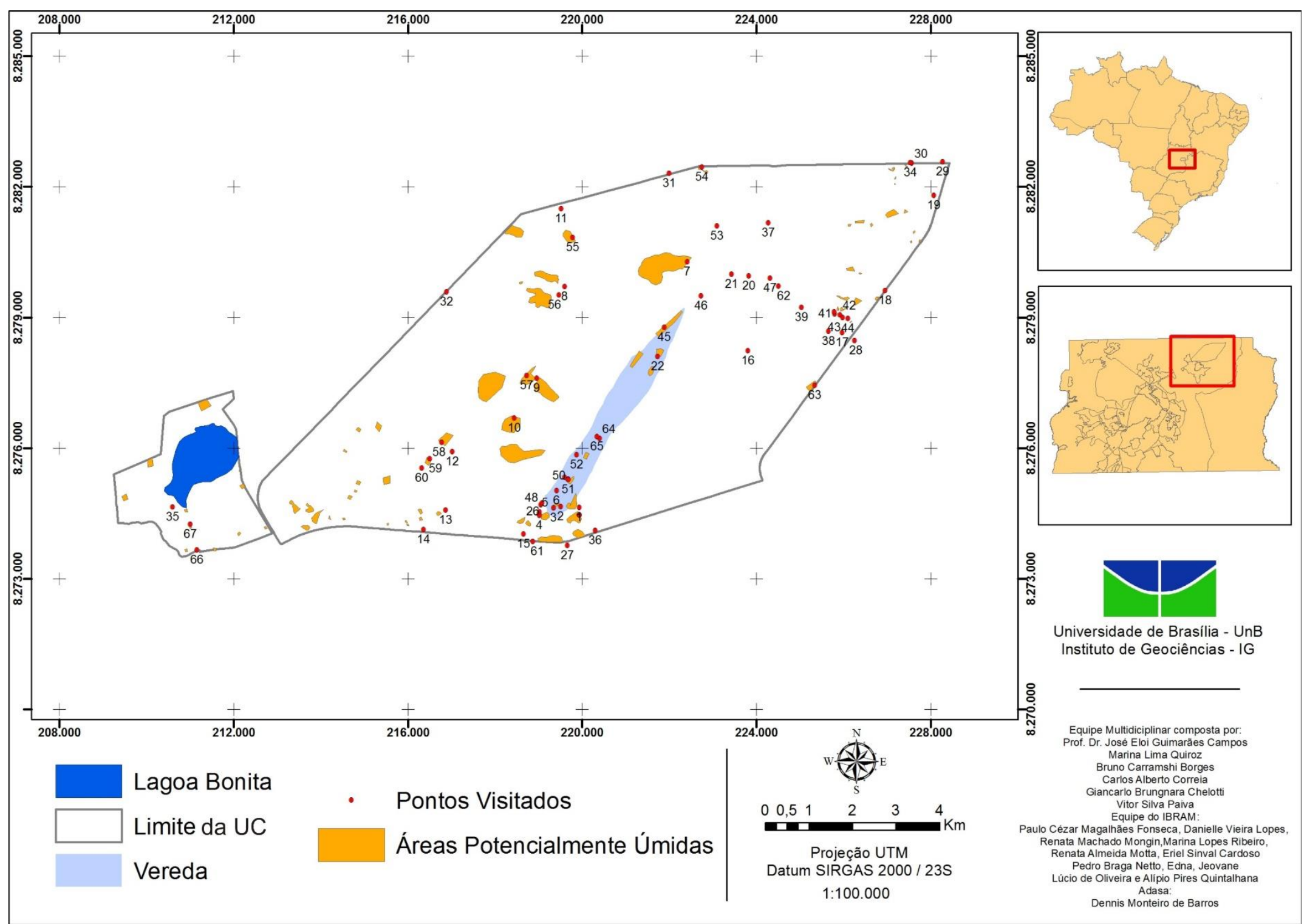

Figura 34 - Mapa de áreas potencialmente úmidas e pontos de levantamento. 
Ao longo do desenvolvimento da análise espacial deste trabalho observou-se que não há uniformização dos contornos da estação ecológica nas publicações de estudos realizados na área, inclusive no Livro Águas Emendadas (Seduma 2008). Os esclarecimentos13 da equipe do Ibram remetem para problemas no Decreto de Criação da Estação Ecológica de Águas Emendadas Decreto N. ${ }^{\circ} 771$, de 12 de agosto de 1968 (Distrito Federal 1968), cujos limites foram alterados pelo Decreto $\mathrm{n}^{\circ}$ 14.662, de 02 de abril de 1993 (Distrito Federal 1993). Segundo as informações prestadas, o polígono estabelecido pelo Decreto inclui as vias que o delimitam e as suas faixas de domínio (que não pertencem à UC). De acordo com a Gerência de Informações Ambientais do Ibram, o Plano Diretor de Ordenamento Territorial do DF - PDOT (Distrito Federal 2012) corrige esses limites. Portanto, os limites da ESECAE utilizados nesta dissertação baseiam-se nas shapes do PDOT disponibilizadas pelo órgão ambiental do DF. Com as novas delimitações do PDOT o cálculo da área total diminui consideravelmente para 9.155,99 ha, aproximadamente.

Outra prática observada nas publicações foi a indisponibilidade para a consulta de metadados básicos, como o Sistema de Referência de Coordenadas e a Projeção Cartográfica. Isto não é um preciosismo, mas necessidade para a produção e reprodução de estudos científicos na área, assim como a padronização do Sistema de Coordenadas Sirgas 2000, cuja adoção oficial no Brasil é obrigatória ${ }^{14}$. Os produtos cartográficos elaborados/refinados neste trabalho com o apoio do Laboratório de Sistemas de Informações Espaciais da UnB - LSIE ${ }^{15}$ utilizam o Datum SIRGAS 2000 e Projeção UTM.

Em síntese o método de levantamento espacial consistiu no desenvolvimento das atividades enumeradas na Tabela 6.

\footnotetext{
${ }^{13}$ Esclarecimentos gentilmente prestados por correio eletrônico.

${ }^{14}$ Desde 25 de fevereiro de 2015, o SIRGAS2000 (Sistema de Referência Geocêntrico para as Américas) é o único sistema geodésico de referência oficialmente adotado no Brasil. Entre 25 de fevereiro de 2005 e 25 de fevereiro de 2015, admitia-se o uso, além do SIRGAS2000, dos referenciais SAD 69 (South American Datum 1969) e Córrego Alegre. O emprego de outros sistemas que não possuam respaldo em lei, pode provocar inconsistências e imprecisões na combinação de diferentes bases de dados georreferenciadas. Disponível em: <http://www.ibge.gov.br/home/geociencias/geodesia/pmrg/faq.shtm>. Acesso em 30 ago. 2015.

${ }^{15}$ Apoio do bolsista Vitor da Silva Paiva.
} 
Tabela 6 - Levantamentos Espaciais de Feições Hídricas na ESEC-AE

\begin{tabular}{|c|c|c|}
\hline Etapa & Atividade & Descrição \\
\hline 1 & Definição da área de estudo: ESEC-AE. & $\begin{array}{l}\text { Critérios de seleção: } \\
\text { - UC emblemática pelas feições hídricas; } \\
\text { - Incentivo à pesquisa; } \\
\text { - Proximidade de Brasília. }\end{array}$ \\
\hline 2 & $\begin{array}{l}\text { Delimitação de áreas com potencial para } \\
\text { modelagem conceitual de feições } \\
\text { hídricas. }\end{array}$ & $\begin{array}{l}\text { Análise e processamento de imagens } \\
\text { (disponibilizadas pela Terracap): } \\
\text {-Critérios de identificação: } \\
\text { a) Nascentes: cabeceiras/ponto de início das linhas } \\
\text { de drenagem; } \\
\text { b) Áreas úmidas: "manchas" com resposta } \\
\text { espectral potencialmente correspondente à índice } \\
\text { de umidade elevado. }\end{array}$ \\
\hline 3 & Validação em campo. & $\begin{array}{l}\text { Visita a áreas com potencial ocorrência das feições } \\
\text { hídricas de interesse: } \\
\text {-Equipe multidisciplinar; } \\
\text {-Logística a partir das vias de acesso; } \\
\text {-Apoio da equipe do Ibram; } \\
\text {-Limitações de: reconhecimento visual; } \\
\text { encaminhamento; tempo; recursos. }\end{array}$ \\
\hline 4 & $\begin{array}{l}\text { Seleção de feições hídricas para a } \\
\text { elaboração de modelos conceituais do } \\
\text { fenômeno. }\end{array}$ & $\begin{array}{l}\text { Seis feições hídricas selecionadas pela } \\
\text { representatividade: } \\
\text { 1. Nascente de fratura; } \\
\text { 2. Vereda; } \\
\text { 3. Cabeceira (Contexto de AU: elevado grau } \\
\text { de hidromorfismo; diversos olhos d'água e } \\
\text { nascente); } \\
\text { 4. Olho d'água condicionado por contato } \\
\text { entre solo arenoso e saprolito argiloso; } \\
\text { 5. Campo de Murundus } \\
\text { 6. Lagoa Bonita. }\end{array}$ \\
\hline 5 & Geoprocessamento & $\begin{array}{l}\text { Elaboração de mapa (apoio de equipe do LSIE): } \\
\text { - Mapa da ESEC-AE com informações de } \\
\text { hidrografia; vias de acesso; pontos de } \\
\text { levantamento com destaque das feições } \\
\text { selecionadas; e polígonos com potencial de } \\
\text { ocorrência de áreas úmidas plotados sobre imagens } \\
\text { disponibilizadas pela Terracap. }\end{array}$ \\
\hline
\end{tabular}

\subsubsection{Levantamentos temporais}

No caso da Estação Ecológica de Águas Emendadas, cujas áreas marginais das feições hídricas são integralmente protegidas, o foco da análise temporal não é orientado para a avaliação de efemeridade, sazonalidade ou perenidade, mas para questões de mudanças ambientais em cenários mais longos. Isto é, distintamente de análises para a aplicação de proteção ao menos 
parcial - como é o caso das APPs em contexto de CAR, por exemplo - baseadas na configuração atual das feições hídricas e na dinâmica do ciclo hídrico anual, a proposta de análise temporal da ESEC-AE é voltada à dinâmica de uma área que tem garantias de proteção elevada, mas que ainda assim apresenta indícios de alteração ao longo do tempo. Enquanto a proposta de levantamentos temporais voltados para a proteção de APPs requer avaliação da configuração das feições hídricas por uma série histórica razoável ao longo de ciclos hídricos anuais (conforme discutido no tópico 3.1.2), a elaboração de cenários temporais para a ESEC-AE baseia-se em indícios e evidências alternativos para um período mais longo.

\section{- Materiais e métodos}

Os levantamentos temporais envolveram consulta de fotografias áreas, imagens orbitais, registros fotográficos realizados em campo e pesquisa bibliográfica. Um dos indícios de redução das áreas úmidas é a complexa transição da fitofisionomia tipificadora de veredas para outras fitofisionomias do cerrado (como mata de galeria, mata alagada e cerrado sensu stricto). Segundo relatos, os padrões da vegetação nas proximidades da Vereda Grande vêm mudando.

Com base na proposta conceitual desta dissertação relativa aos solos com elevado grau de hidromorfismo como critério identificador de áreas úmidas, as mudanças ambientais em feições hídricas foram analisadas em relação à evolução dos solos. O refinamento do mapa pedológico (Figura 35), apresentado como subproduto desta dissertação, revela evidências de transformações progressivas nas classes de solos presentes na área, em função variações no grau de hidromorfismo de solos, isto é, em função de mudanças na dimensão das AUs ao longo do tempo. 


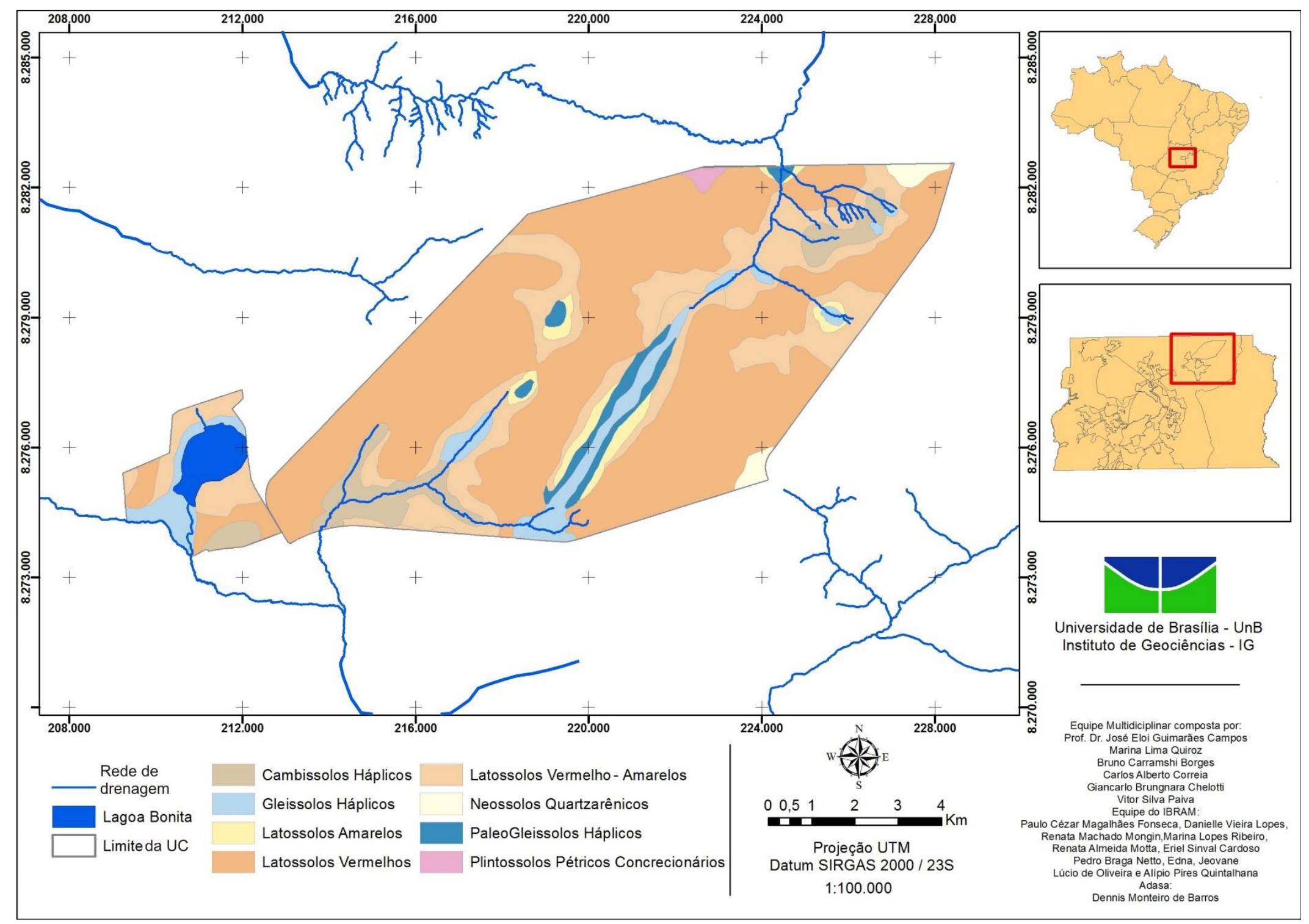

Figura 35 - Refinamento do Mapa Pedológico. Pedossequência fundamenta análise espaço-temporal dos processos relativos às feições hídricas na ESECAE, com base no critério identificador de elevado grau de hidromorfismo para AUs proposto nesta dissertação. 
Como resultado inédito, mapeou-se pedossequência atípica para a região de cerrados com a transição entre Gleissolos e Latossolos Vermelho-Amarelos bem marcada pela presença intermediária de Paleogleissolo e Latossolo Amarelo, em função de perda progressiva de características de alto grau de hidromorfismo, isto é, em função da oxidação paulatina do solo. Além do mapeamento em detalhe das manchas transicionais de Paleo Gleissolo para Latossolo Amarelo (LA) entre as ocorrências de Gleissolo (GX) e Latossolo Vermelho-Amarelo (LVA), por vezes em contato direto com Latossolo Vermelho (LV), os limites do Cambissolo (Cx) também foram ampliados. Além disso, foram propostas ligeiras modificações no mapeamento de Neossolos Quartzarênicos. Pequena ocorrência de Plintossolo Petroplíntico foi delimitada na porção norte da área.

Este estudo toma por base os mapas de solos e de pedoformas, disponibilizados respectivamente por EMBRAPA (1978) e de Lacerda in Seduma (2008). Essa análise temporal também fundamenta a análise de processos de diminuição de AUs no contexto da Lagoa Bonita (detalhada no modelo conceitual).

Subsidiariamente, observaram-se a respostas da vegetação às possíveis retrações progressivas de áreas úmidas. Aparentemente, a resposta fitofisionômica às mudanças da distribuição hídrica nos solos é consideravelmente mais rápida que as transformações observáveis dos próprios solos. Tais transformações pedogenéticas se processam na escala do tempo geológico de maneira moderada, como resposta aos processos de oxirredução.

A partir desses levantamentos para a compreensão do fenômeno da dinâmica das feições hídricas, os cenários temporais fundamentaram-se em compilação de informações de estudos palinológicos, geomorfológicos e paleogeográficos para área.

Em síntese, a etapa dos levantamentos temporais consistiu nas seguintes atividades (Tabela 7).

Tabela 7 - Levantamentos Temporais de Feições Hídricas na ESEC-AE.

\begin{tabular}{||c|c|c||}
\hline \hline Etapa & Atividade & Descrição \\
\hline \hline 1 & Definição da escala temporal. & $\begin{array}{c}\text { Análise modulada à questão: } \\
\text { - Mudanças ambientais ao longo do tempo; } \\
\text { - Dinâmica de configuração das feições hídricas. }\end{array}$ \\
\hline 2 & $\begin{array}{c}\text { Investigação de indícios de } \\
\text { mudanças ambientais. }\end{array}$ & $\begin{array}{c}\text {-Referências bibliográficas; } \\
\text {-Levantamentos de campo. }\end{array}$ \\
\hline 3 & Levantamentos pedológicos. & $\begin{array}{c}\text { Refinamento do mapeamento pedológico (com } \\
\text { base em Lacerda in Seduma 2008) }\end{array}$ \\
\hline 5 & Geoprocessamento. & $\begin{array}{c}\text { Elaboração de mapa (apoio do LSIE): } \\
\text { - Mapa pedológico da ESEC-AE. }\end{array}$ \\
\hline
\end{tabular}




\subsubsection{Produto: cenários espaço-temporais}

A reconstituição dos cenários temporais para a ESECA-AE partiu da integração da interpretação palinológica (Barberi in Seduma 2008) com a avaliação de pedossequências na ESEC-AE proposta por esta dissertação, resultante do refinamento do mapeamento pedológico apresentado no tópico de levantamentos temporais (tópico 4.1.2).

Os sedimentos estratificados, ricos em matéria orgânica, que se desenvolvem sob condições redutoras possibilitam datações radiométricas por Carbono 14, além da preservação de palinomorfos e permitem a execução de análises paleoecológicas, voltadas para o estabelecimento da evolução da paisagem a partir da caracterização do conjunto da vegetação no decorrer do tempo geológico (Salgado-Laboriau 1994). Os palinomorfos incluem pólen de Gimnospermas e Angiospermas, esporos de Pteridófitas e de fungos, além de algas microscópicas e partículas de carvão e são produzidos em grande quantidade e dispersos a grandes distâncias pelas correntes de ar ascendentes, o que possibilita uma boa representatividade tanto da vegetação local como da regional (Faegri \& Iversen apud Barberi in Seduma 2008).

Segundo Barberi (in Seduma 2008), os registros de pólens preservados em solos redutores permitem a identificação de modificações na vegetação da área - que indicam mudanças climáticas e, consequentemente, mudanças ecológicas. A autora esclarece que na ESEC-AE "condições climáticas diferentes das atuais, marcadas por um clima mais frio e úmido, propiciaram a acumulação e preservação de sedimentos, restos vegetais e matéria orgânica, dando origem a uma turfa desenvolvida no decorrer dos últimos 26.000 anos antes do presente16, acumulando uma sequência sedimentar com cerca de 2,6m de espessura".

Conforme a pesquisadora, quatro fases modificaram profundamente o cenário da área, o que têm implicações sobre a ocorrência das feições hídricas. A integração entre as reconstruções paleoambientais de Barberi (in Seduma 2008) e os registros da evolução dos solos permite a elaboração dos seguintes cenários espaço-temporais de distribuição de nascentes e áreas úmidas na área, especialmente na Vereda Grande (Tabelas 8 a 11).

\footnotetext{
${ }^{16}$ Antes do Presente (AP) é convencionalmente representado pelo número de anos passados desde um cenário anterior, precedido do símbolo negativo (-).
} 
Tabela 8 - Cenário espaço-temporal: fase I, entre 25.790 \pm 70 AP e 23.380 AP. Modificado de Barberi (in Seduma 2008).

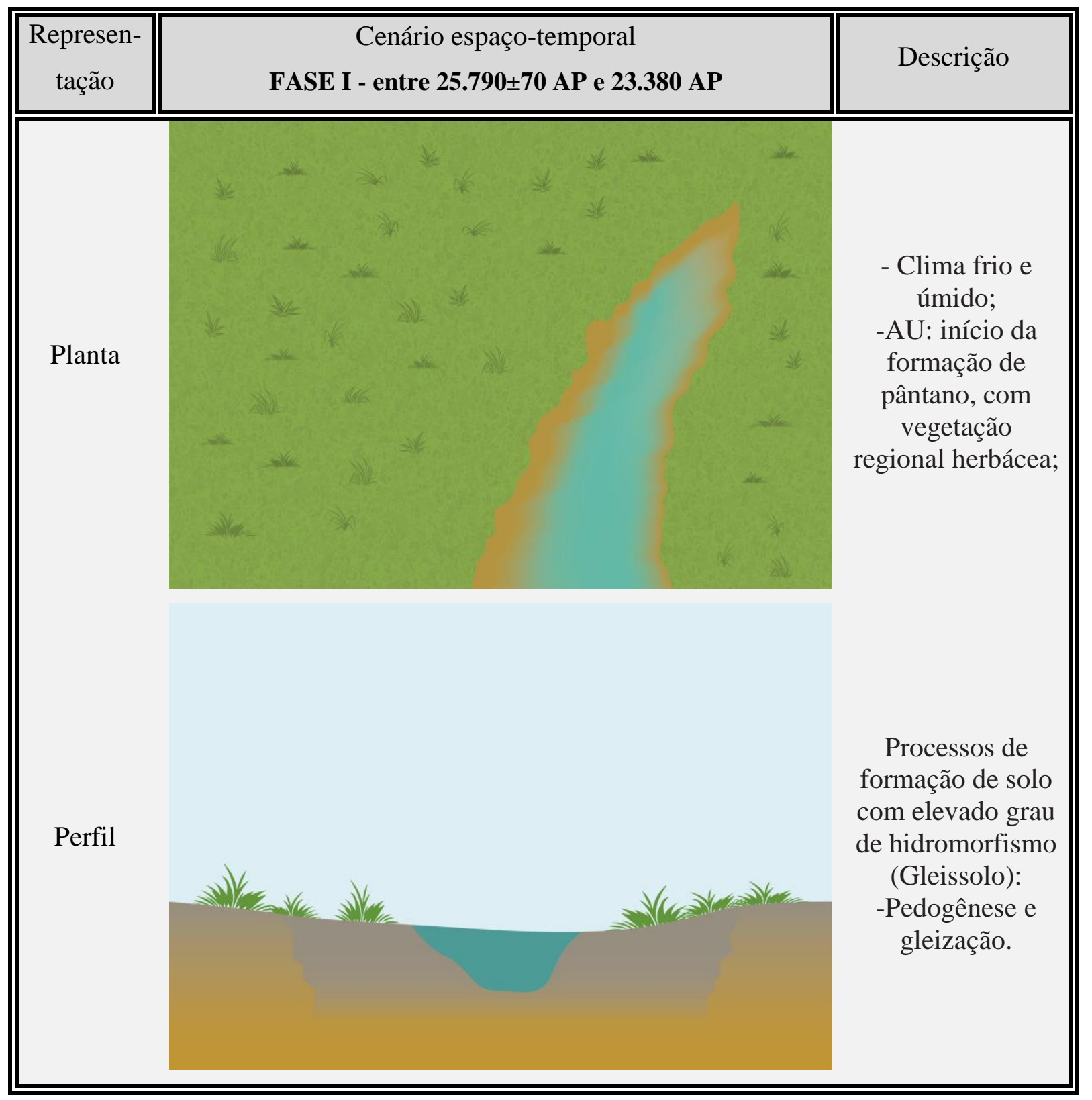


Tabela 9 - Cenário espaço-temporal: fase II - entre 23.380 (idade interpolada) e 21.450 \pm 100 AP. Modificado de Barberi (in Seduma 2008)

\begin{tabular}{|c|c|c|}
\hline $\begin{array}{l}\text { Represen- } \\
\text { tação }\end{array}$ & 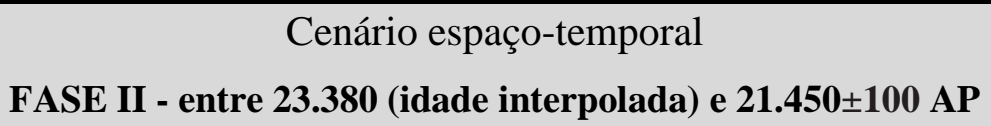 & Descrição \\
\hline Planta & 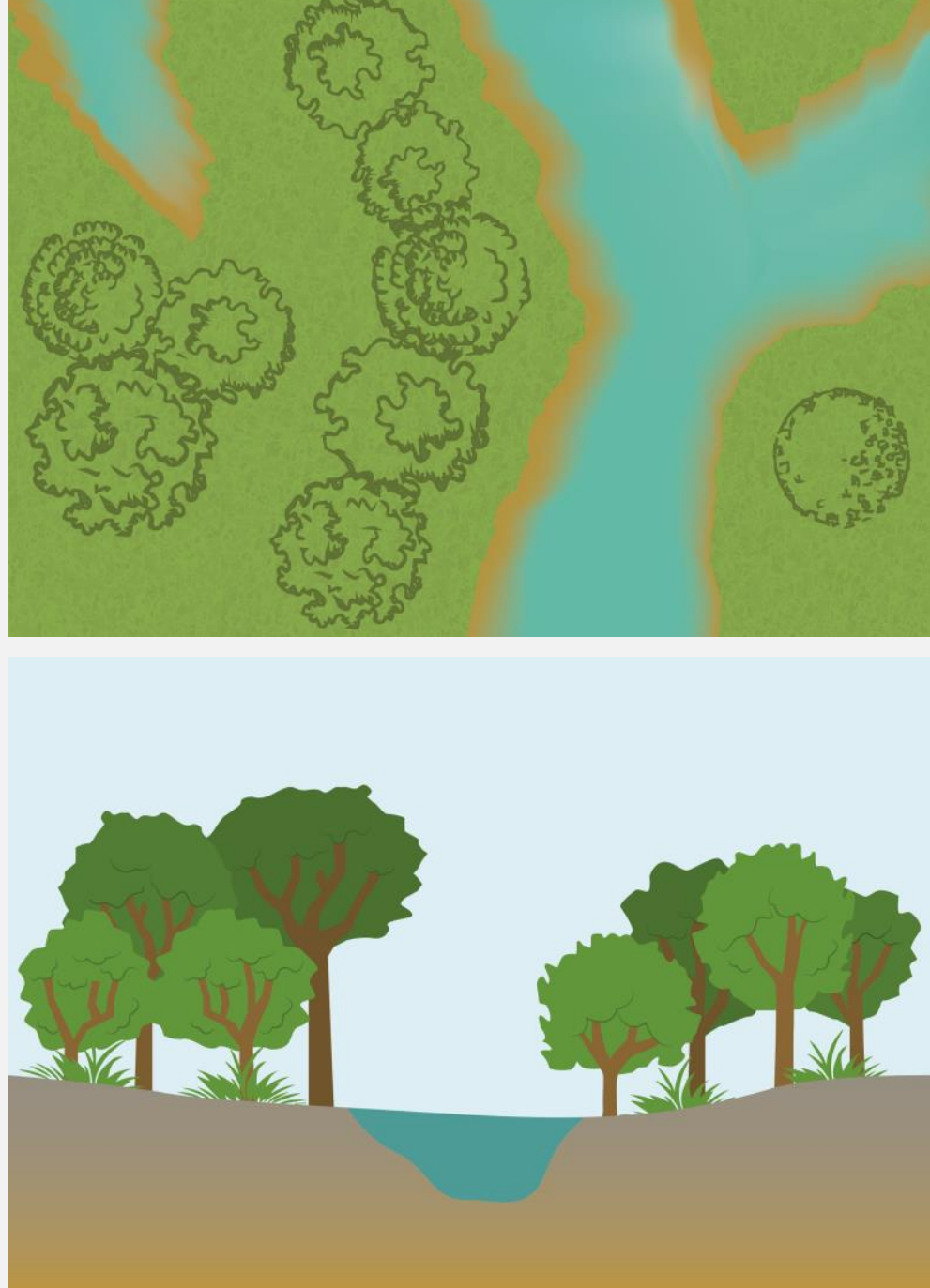 & $\begin{array}{l}\text {-Clima mais frio e } \\
\text { úmido que a fase } \\
\text { I; } \\
\text {-Máximo por } \\
\text { volta de } 22.230 \\
\text { (idade } \\
\text { interpolada); } \\
\text {-Desenvolvimento } \\
\text { de uma mata } \\
\text { galeria e um } \\
\text { cerrado arbóreo } \\
\text { regionalmente; } \\
\text {-Maior } \\
\text { biodiversidade. } \\
\\
\text { Ampliação dos } \\
\text { processos de } \\
\text { formação de solo } \\
\text { com elevado grau } \\
\text { de hidromorfismo } \\
\text { (Gleissolo): } \\
\text {-Pedogênese; } \\
\text {-Gleização; } \\
\text {-Formação de } \\
\text { horizontes } \\
\text { superficiais } \\
\text { orgânicos; } \\
\text {-Turfeiras. }\end{array}$ \\
\hline
\end{tabular}


Tabela 10 - Cenário espaço-temporal - FASE III - 21.450 \pm 100 AP a 7.220 \pm 50 AP.

Modificado de Barberi (in Seduma 2008).

\begin{tabular}{|c|c|c|}
\hline $\begin{array}{l}\text { Represen- } \\
\text { tação }\end{array}$ & 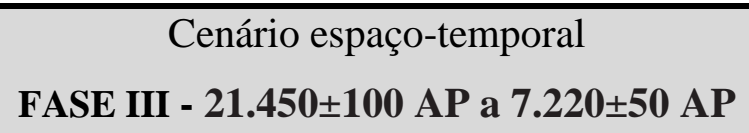 & Descrição \\
\hline Planta & 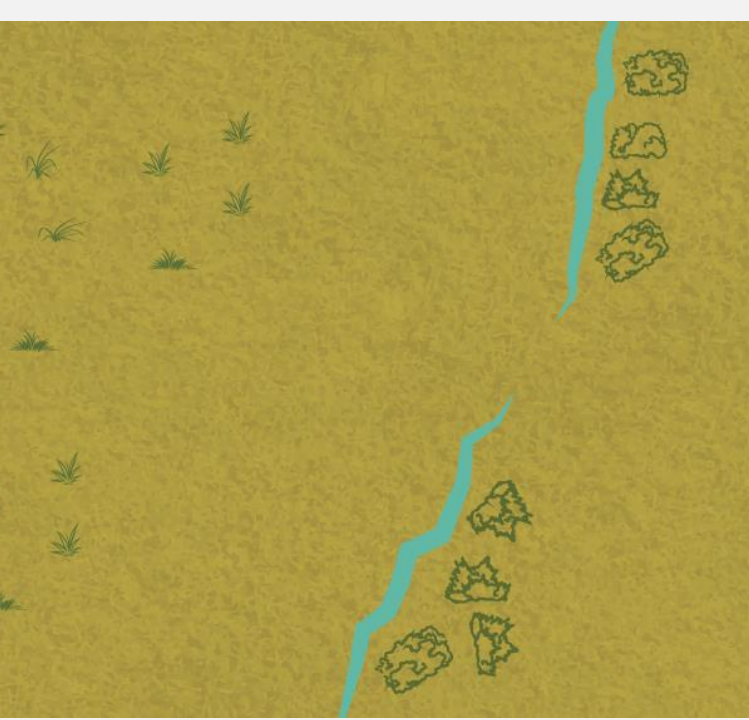 & $\begin{array}{l}\text {-Clima muito mais } \\
\text { seco e frio que a fase } \\
\text { II e que a atual; } \\
\text {-Ausência quase } \\
\text { total do pólen, } \\
\text { esporos e das algas; } \\
\text {-Retração acentuada } \\
\text { da cobertura vegetal } \\
\text {-Aumento da } \\
\text { deposição de } \\
\text { material detrítico; } \\
\text { - Redução } \\
\text { dimensional máxima } \\
\text { de AUs entre as } \\
\text { fases registradas. }\end{array}$ \\
\hline Perfil & & $\begin{array}{l}\text {-Formação da } \\
\text { pedossequência } \\
\text { resultante de } \\
\text { processos de } \\
\text { oxidação do solo, } \\
\text { relacionados às } \\
\text { mudanças climáticas; } \\
\text {-Solos deixam de ser } \\
\text { regionalmente } \\
\text { redutores e } \\
\text { Gleissolos ficam } \\
\text { restritos a áreas } \\
\text { úmidas; } \\
\text { - Sequência } \\
\text { gradacional entre } \\
\text { classes de solos mais } \\
\text { redutoras para mais } \\
\text { oxidantes, } \\
\text { determinadas pelo } \\
\text { distanciamento } \\
\text { progressivo de AUs: } \\
\text { Gx, PGx, LA, LVA e } \\
\text { LV. }\end{array}$ \\
\hline
\end{tabular}


Tabela 11 - Cenário espaço-temporal - FASE IV - 7.220 \pm 50 AP até o presente.

Modificado de Barberi (in Seduma 2008).

\begin{tabular}{|c|c|c|}
\hline $\begin{array}{l}\text { Represen- } \\
\text { tação }\end{array}$ & $\begin{array}{c}\text { Cenário espaço-temporal } \\
\text { FASE IV } \boldsymbol{-} \mathbf{7 . 2 2 0 \pm \mathbf { 5 0 }} \mathbf{A P} \text { até o presente }\end{array}$ & Descrição \\
\hline Planta & 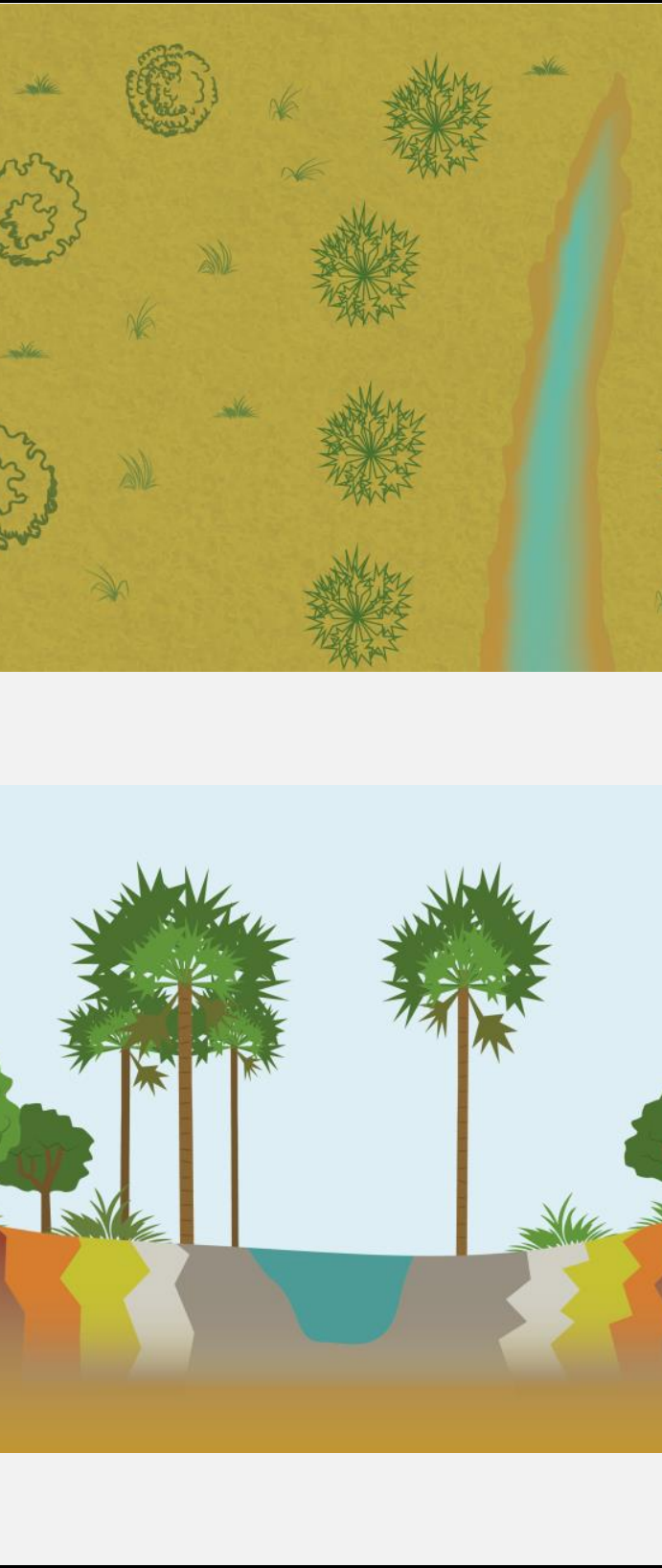 & $\begin{array}{l}\text {-Implantação da } \\
\text { Vereda Grande, } \\
\text { marcada pela } \\
\text { presença de pólen de } \\
\text { Mauritia, ausente } \\
\text { nas fases anteriores; } \\
\text { - Diminuição de } \\
\text { elementos arbóreos } \\
\text { em relação a } \\
\text { sequência da turfa } \\
\text { inferior; } \\
\text {-Ausência dos } \\
\text { indicadores de clima } \\
\text { frio. } \\
\text {-Evolução da } \\
\text { pedossequência } \\
\text { resultante de } \\
\text { processos de } \\
\text { oxidação do solo, } \\
\text { relacionados às } \\
\text { mudanças climáticas; } \\
\text { - Sequência } \\
\text { gradacional LV } \rightarrow \\
\text { LVA } \rightarrow \text { LA } \rightarrow \text { PGx } \\
\rightarrow \text { Gx apresenta } \\
\text { ampliação do } \\
\text { gleissolo em função } \\
\text { de relativa expansão } \\
\text { da AU (vereda } \\
\text { tipificada por } \\
\text { presença de buriti em } \\
\text { complexo } \\
\text { vegetacional). }\end{array}$ \\
\hline
\end{tabular}

Para Barberi (in Seduma 2008), os dados estão em acordo com outras regiões recobertas por cerrados no Brasil Central e apresentam uma nítida correlação com as alterações do último glacial Wurm/Wisconsin registradas na região dos Andes Tropicais. A autora conclui que variações registradas tanto no que diz respeito ao tipo de vegetação predominante em cada período de tempo quanto a extensão dos eventos, estão relacionadas as particularidades da região de Águas Emendadas, onde a compartimentação geomorfológica representada por um sistema particular de dispersão da drenagem reflete variações de caráter regional. 
Esta análise de cenários espaço-temporais baseados em registros do solo - palinológicos e pedológicos - revela que a variação dimensional de áreas úmidas é dinâmica e relacionada principalmente a processos naturais de mudanças climáticas. As AUs aumentaram na última fase que se estende até o presente, com a implantação da fitofisionomia tipificadora de veredas na ESEC-AE.

Esses dados incitam reflexão quanto à questão que motivou esta análise espaço-temporal: as veredas estão diminuindo? Como protegê-las?

Ciências naturais não são exatas, por definição. Mas as considerações podem levar em conta alguns aspectos objetivos:

-Veredas correspondem à classes de AUs identificadas por solos com elevado grau de hidromorfismo e caracterizadas por fitofisionomia composta por complexo vegetacional, com presença típica de buritis.

-O complexo vegetacional da fitofisionomia é dinâmico no tempo e no espaço (conforme abordado no capítulo 3.2.1). A transição entre fitofisionomias do cerrado diretamente relacionadas a feições parece obedecer tendência espacial de encaixe de linha do talvegue. Progressivamente do relevo mais plano para os vales mais encaixados a sequência fitofisionômica do cerrado aparentemente tende a ser: campo úmido/campo de murundus/brejo $\rightarrow$ vereda/mata alagada/palmeiral $\rightarrow$ mata de galeria/mata ciliar.

-A largura da área úmida (determinada pelo critério de solo com elevado grau de hidromorfismo) também tende a diminuir com o encaixe da linha de drenagem, pela facilitação do escoamento da água.

-Tanto vegetação, quanto solo se modificam com alterações climáticas e geomorfológicas. Apesar disso, as alterações na vegetação têm resposta mais rápida que as alterações nas características do solo.

Portanto, conclui-se que as veredas estejam passando por um processo natural de evolução fitofisionômica, que tende à transformação em outra fitofisionomia com características próprias. A ponderação sobre como protege-las de maneira mais razoável conduz à utilização do critério identificador e não caracterizador para a aplicação de instrumentos de proteção, ou seja, o solo com elevado grau de hidromorfismo. A ele está associado um processo mais longo de equilíbrio dinâmico natural, o que oferece possibilidade mais abrangente de proteção. Isso porque, apesar de o processo ser natural, a ação antrópica eventualmente pode catalisá-lo ou potencializá-lo. A proteção às feições hídricas é fundamental para garantir que os processos naturais e as funções ecossistêmicas continuem se desenvolvendo.

Além da avaliação de cenários espaço-temporais, a proteção das feições hídricas passa pela caracterização e modelagem das feições hídricas, de maneira a modular a gestão e empregar os instrumentos de maneira adequada. 


\subsection{Caracterização das Feições}

A etapa de caracterização das feições hídricas consistiu na descrição multidisciplinar baseada em critérios tipificadores verificados nos levantamentos bibliográficos e de campo. A partir da amarração do cenário espaço-temporal presente (ou seja, da determinação da configuração atual) das feições hídricas com a etapa de caracterização, geraram-se como produtos os modelos conceituais para seis feições hídricas consideradas mais representativas sob a óptica da proposta deste estudo.

\begin{tabular}{||c|c|c|}
\hline Etapa & Atividade & Descrição \\
\hline \hline 1 & $\begin{array}{c}\text { Descrição multidisciplinar quanto a } \\
\text { critérios tipificadores }\end{array}$ & $\begin{array}{c}\text {-Referências bibliográficas; } \\
\text {-Levantamentos de campo. }\end{array}$ \\
2 & Cenário espaço-temporal presente & $\begin{array}{c}\text { Configuração atual de seis feições hídricas } \\
\text { representativas }\end{array}$ \\
\hline 3 & Produto integrado & Modelo conceitual \\
\hline
\end{tabular}

\subsubsection{Descrição das feições quanto aos critérios tipificadores por meio de levantamentos} bibliográficos e de campo

- Bioma: a ESEC-AE enquadra-se no contexto do bioma Cerrado e é reconhecida como integrante do Programa "O Homem e a Biosfera” da Unesco como Reserva da Biosfera do Cerrado (Schenkel in Seduma 2008). Ou seja, é um rico exemplar das fitofisionomias do bioma. O Cerrado constitui região fitogeográfica heterogênea formada por um mosaico vegetacional, com inclusões de formações florestais, em meio às formações savânicas e campestres de sua paisagem (Ferreira, 1980; Ribeiro \& Walter, 1998).

O Cerrado apresenta algumas fitofisionomias típicas de áreas úmidas. Para a elaboração de modelos conceituais, a caracterização por meio do elemento da vegetação pode auxiliar na tipificação e na delimitação da AU. Dentro de uma mesma fitofisionomia, teoricamente é possível fazer inferências nas alterações dos condicionantes físicos das AUs por meio dos gradientes vegetacionais relacionados às concentrações de exemplares das espécies.

As AUs em geral podem estar relacionadas aos seguintes ambientes do cerrado, conforme a classificação de Walter (2006): Vereda, Matas Ciliares, Matas de Galeria, Brejo, Campo Úmido, Campo com Murundus, Palmeiral. A discussão traçada pelo autor abrange tanto questões relativas às diferentes nomenclaturas usadas para os ambientes do cerrado, quanto às espécies que ocorrem em cada um e do índice de 
similaridade entre eles. Esse estudo de referência sobre o tema conclui que há um uso excessivo de expressões referentes às diferentes fitofisionomias do bioma e que os autores muitas vezes desconsideram as produções científicas anteriores, com consequente criação de novos termos desnecessários para denomina-las. Além disso, aponta o grau de similaridade entre as fitofisionomias. Da tese depreende-se que os diferentes graus de similaridade de ocorrência de espécies entre os ambientes envolvem grande complexidade de análise. Disto pode-se inferir que, se uma mesma espécie ocorre em ambientes diferentes, basear-se em na espécie como critério identificador de ambiente não é preciso. Assim, a argumentação aqui traçada é a de que a vegetação é um critério caracterizador de áreas úmidas, mas não identificador.

Esta posição parece ser corroborada pela argumentação tecida no trabalho de Walter (2006), em que o autor para diferenciar 24 ambientes gerais dentro do cerrado, após exaustiva pesquisa de termos utilizados na bibliografia, fez as seguintes considerações:

Várias indicações de ambiente (...) foram aqui inseridas em mais de um ambiente geral. Exemplos disso são o "campo limpo (úmido)", considerado tanto para o "Campo Limpo", quanto para o "Campo Úmido"; ou "lagoa", indicada tanto para "Brejo" quanto para "Vegetação ribeirinha e ciliar". Isto se fez necessário, pois inúmeras espécies ocorrem em mais de um ambiente e, quando os ambientes foram segmentados para as análises, as espécies nesta situação tiveram que ser consideradas em cada um deles. A mesma lógica foi usada para transições entre dois ambientes Exemplo: espécie da "transição cerrado (stricto sensu)" com "vereda" foi considerada tanto no ambiente "cerrado (stricto sensu)" quanto no "vereda". Em alguns casos isto pode ocasionar erros de interpretação, mas, baseado na lista, não havia como indicar com segurança em qual dos dois haveria uma ocupação preferencial da espécie; se é que há.

A relação dos ambientes supracitados com a fitofisionomia é encontrada na literatura com as seguintes descrições:

\section{-Veredas:}

"Cabeceiras: Sempre que nos baixios das chapadas e nas encostas das serras ha ajuntamento de aguas e consequentemente se formam pantanos, nascem regos, riachos, isto é, -cabeceiras- de rios... Aqui apparece então vistosa palmeira de leque ora em raros exemplares, ora disposta em grupos ou junta a outras plantas arboreas, arbustivas e herbaceas formando bosques chamados-capões; dá a essas localidades um aspecto todo particular e é por este motivo que se póde considerá-la como formação propria, especial: a dos burytizaes e capões. ... Chama-se Mauritia vinifera, Mart.; ou (de seu nome indigena) -burity- essa majestosa palmeira e traz á lembrança do viajante -nada que mais avistará senão campos e cerradosque elle se acha em latitudes tropicaes..."

Foi assim que o botânico da Missão Cruls Ernesto Ule descreveu a fitofisionomia relacionada a cabeceiras entre os anos de 1892 e 1893, em pontos de referência 
próximos à Águas Emendadas - como a Lagoa Bonita, o Itiquira e o município de Formosa (Borghetti \& Pujol-Luz in Seduma 2008). A descrição sugere referência direta a veredas, ainda que as características transicionais com as matas de ciliares e matas de galeria chamem a atenção. Os registros datam de mais de um século e trazem indícios da ocorrência de buritis em múltiplos contextos: "ora raros exemplares" como em renques ou alamedas, "ora disposta em grupos" possivelmente com formação de dossel, "ou junta a outras plantas arbóreas, arbustivas e herbáceas (com adaptações do texto original)", contexto que pode fazer referência a ambientes transicionais ou como Araújo et al. (2002) descrevem “complexo vegetacional” (Figura 36).

$\mathrm{Na}$ ESEC-AE, encontram-se veredas nos mais variados contextos.

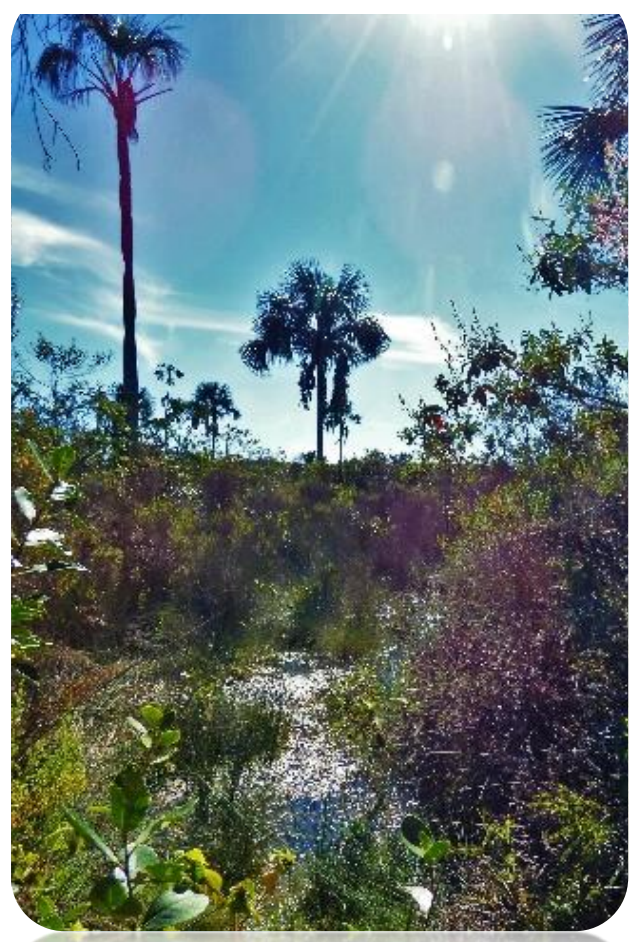

Figura 36 - Complexo vegetacional da Vereda Grande, ESEC-AE. Fonte: arquivo pessoal.

Walter (2006) sugere a adoção do termo "Vereda", agregando os usos redundantes dos termos "vereda + vereda (borda) + borda de vereda + vereda (com lagoas temporárias) + transição de cerrado (stricto sensu) com vereda".

- Matas Ciliares: por vezes Matas Ciliares e Matas de Galeria são utilizadas como sinônimos. Mas o termo "Matas Ciliares" é mais amplo. Geralmente faz referências a rios largos, em que a copas das árvores de uma margem não tocam as copas das árvores da outra margem (Felfili et al. 2000). Isso tem implicações relacionadas à radiação solar que chega ao curso do rio, com influência sobre as espécies relacionadas à área de abrangência do rio e zona marginal (Ribeiro et al. 1999).

Walter (2006) sugere a adoção do termo "Mata ciliar", agregando os usos dos termos "mata ciliar + beira de mata ciliar + borda de mata (ciliar) + borda de mata ciliar (de 
encosta) + mata (ciliar) + mata ciliar (ambiente rupestre) + mata ciliar (de encosta/encosta) + mata ciliar (de galeria) + mata ciliar (inundável) + mata inundável + transição mata ciliar com campo úmido".

\section{- Matas de Galeria:}

A mata de galeria do cerrado margeia rios estreitos, de maneira a formar dossel sobre o curso d'água, ou seja, as copas das árvores de uma margem interceptam as copas das árvores da outra margem. A incidência de radiação solar direta sobre os rios é reduzida. É uma fitofisionomia que não apresenta queda de folhas durante o período seco e que geralmente é margeada por áreas não florestais (Ribeiro \& Walter 1998).

Segundo Felfili et al. (2000), há matas de galeria inundáveis e não inundáveis. As inundáveis apresentam menor número de espécies, com dominância de espécies típicas de áreas úmidas, como jaca-brava (Richeria grandis) e pindaíba do brejo (Xylopia sericea), com maior número de espécies de árvores finas que as matas de galeria em solos bem drenados.

Felfili et al. (in Seduma 2008) descrevem as matas de galeria em Águas Emendadas como alagáveis. De acordo com os autores,

seus solos apresentam condições favoráveis ao desenvolvimento de vegetação florestal contando com um elevado teor de matéria orgânica proveniente da ciclagem de nutrientes da própria mata. Grande parte destas matas ocupam solos hidromórficos estacionalmente inundáveis. Os solos desenvolvidos sob influência do lençol freático permanecem saturados na estação chuvosa, contêm horizontes superficiais organo-minerais, estando a matéria orgânica, oriunda das folhas desprendidas das árvores (folhedo), total ou parcialmente decomposta.

As matas que ocupam solos estacionalmente alagados ou alagáveis apresentam grande número de indivíduos finos quando comparadas com as matas que colonizam solos bem drenados. A espécie emergente típica dessa tipologia é o buriti, Mauritia flexuosa (Palmae), que ocorre associada a espécies típicas de ambientes alagáveis como pindaíba (Xylopia emarginata), landim (Calophyllum brasiliense), magnólia-do-brejo (Taluma ovata) entre outras Comunidades de orquídeas, bromélias e outras epífitas são particularmente abundantes nas matas de galeria.

Walter (2006) sugere a adoção do termo "Mata de Galeria", agregando os usos dos termos " mata de galeria + borda de mata (de galeria) + borda de mata de galeria + borda de mata de galeria (encosta) + borda de mata de galeria com cerrado (lato sensu) + borda de mata de galeria inundável + margem de córrego + mata (de brejo) + mata de encosta + mata (de galeria) + mata ciliar (de galeria) + mata de encosta + mata de galeria (alterada) + mata de galeria $($ borda $)+$ mata de galeria $($ de encosta + mata de 
galeria (de vale) + mata de galeria (encosta) + mata de galeria (inundável) + mata de galeria (margem de córrego) + mata de galeria (não-inundável) + mata de galeria de encosta + mata de galeria (inundável) + mata de galeria (margem de córrego) + mata de galeria (não-inundável) + mata de galeria de encosta + mata de galeria inundável + mata de galeria não inundável + transição mata de galeria com cerrado (lato sensu) + transição com campo (limpo) + transição mata de galeria com campo úmido".

- Brejo: formação helophila relacionada a solos ricos em água na margem das lagoas ou ao longo dos cursos d'água, embora haja diferença na vegetação dos brejos em diferentes localidades, segundo Warming (1973). Conforme Ribeiro e Walter (1998), brejo é uma palavra com conceitos muito diferenciados. "Pode-se definir brejo como uma área cujo solo é saturado com água permanentemente, o que, no Brasil Central, propicia a ocorrência de buritis e também de arbusto se arvoretas adensadas, adaptadas a este ambiente de estresse...". Walter (2006) sugere a adoção do termo "Brejo", agrupando os termos redundantes "brejo + buritizal + brejo (lagoa) + lagoa".

- Campo Úmido: segundo Felfili et al. (in Seduma 2008), "na Estação Ecológica de Águas Emendadas, os campos limpos se destacam sobre solos rasos, como Cambissolos e Litossolos, e quando úmidos sobre solos hidromórficos. Os campos ocorrem também margeando matas de galeria e as linhas de buritis nas veredas, em solos inundáveis, especialmente sobre solos hidromórficos, gleys (sic.) e orgânicos turfosos". Na classificação de Ribeiro e Walter (1998), o adjetivo "úmido" é usado como subtipo de vegetação, podendo estar associado tanto ao Campo Sujo quanto ao Campo Limpo. Walter (2006) sugere a adoção do termo "Campo Úmido", agregando os usos dos termos "campo úmido + campo (inundado) + campo (úmido) + campo inundável + campo limpo (úmido) + campo limpo úmido + campo sujo (úmido) + campo úmido (alagado) + campo úmido (várzea)".

- Campo com Murundus: de acordo com Felfili et al. (in Seduma 2008), “os murundus são ilhas com vegetação lenhosa encontradas sobre pequenas elevações nos campos limpos e nas bordas das veredas. Nessas áreas, as condições de drenagem são favoráveis ao estabelecimento e desenvolvimento dos propágulos das espécies arbóreas, oriundas dos cerrados nas vizinhanças. Walter (2006) considera com grande incerteza campo de Murundus sinônimo de "Parque de Cerrado" e sugere a adoção do termo "Campo com Murundus", agregando os usos dos termos "campo com murundus + campo limpo com murundus + campo úmido (com murundus)".

- Palmeiral: Sobre as espécies de palmeiras, Felfili et al. (2000) descrevem as espécies mais adaptadas a áreas bem drenadas e a áreas úmidas, além daquelas que podem ser encontradas nos dois contextos. Macaúba (Acronomia sclerocarpa, Mart.) e jerivá arbóreo (Arecastrum romanzoffianum, Becc.) são típicos de áreas mais bem drenadas. 
Em matas úmidas ocorrem os buritis (Mauritia flexuosa, Mart.). Em ambas, podem ocorrer vassoura arbustiva (Butia leiopatra, Mart.), palmito arbóreo (Euterpe Edulis, Mart.) e pupunha arbórea (Guilielma gasipaes, HBK).

Walter (2006) sugere a adoção do termo "Palmeiral", agregando os usos dos termos "babaçual + palmeiral (babaçual) + palmeiral (carandazal, carnaubal)".

*Vegetação: conforme descrito acima, os ambientes do cerrado existentes ESEC-AE mais típicos de áreas úmidas são compostos por complexos vegetacionais que se interrelacionam com outros por transição e que possuem espécies comuns. Assim, não é possível utilizar uma espécie como critério identificador de uma feição hídrica (ou ambiente), a exemplo do que convencionalmente vem sendo feito na relação buritis $\rightarrow$ veredas. Acredita-se, sim, que os buritis são elementos descritivos que se aplicam como critérios caracterizadores de nascentes, veredas e áreas úmidas. Ou seja, vegetação é critério tipificador e não classificador.

Uma discussão que tem sido travada em relação às veredas na ESEC-AE é a de que há indícios de transformação de paisagens marcadas pela transição de vegetação de veredas com outras fitofisionomias. Segundo Munhoz e Ribeiro (in Seduma 2008):

As veredas normalmente fazem vizinhança com o cerrado (lato sensu) nas porções com maior drenagem; com os campos úmidos onde a drenagem é insuficiente; e com as matas de galeria nos fundos dos vales ou nas cabeceiras de drenagem (Eiten, 1983, 1994). Em fases mais evoluídas da vereda, podem ser encontradas ilhas de vegetação lenhosa junto aos buritis. Quando os vales tornam-se mais encaixados e o lençol freático é rebaixado, as veredas dão lugar às matas de galerias (Melo, 1992). Supõe-se que a vereda seja uma das fases para a formação ou expansão da mata de galeria, tendo como base a ausência de buritis jovens nas matas estabelecidas, a inexistência de um dreno ou córrego definido na vereda e outras condições, como pouco sombreamento, que permitam a ocupação de outras espécies arbóreas (Ribeiro \& Walter, 1998).

Eiten (2001) classifica a vereda como unidade de vegetação formada por três faixas paralelas de diferentes tipos vegetacionais; a primeira representada por campo úmido sazonal, alagado somente no auge das chuvas, a qual o autor denomina brejo estacional graminoso; a segunda faixa apresenta o campo úmido alagado permanentemente, tendo sido denominada brejo permanente graminoso; e por último a faixa de buritizal, também sob (sic) solo saturado. Brandão et al. (1991) e Araújo et al. (2002) também reconhecem na vereda três zonas de vegetação relacionadas à topografia e a drenagem do solo, designando-as de borda, onde o solo e mais seco, e em meio a vegetação campestre podem ocorrer arbustos e pequenas arvores isoladas; meio, com solo com alagamento sazonal e vegetação predominantemente herbáceo-subarbustiva; e fundo, que apresenta 
solo permanentemente saturado com água, brejoso, onde ocorrem os buritis, muitos arbustos e arvoretas adensadas. Segundo esses autores, estas zonas são floristicamente diferenciadas, cujos reflexos emergem sobre a flora zonal. As duas primeiras zonas correspondem a faixa tipicamente campestre e o fundo corresponde ao "bosque sempre-verde", de Magalhães (1966). Por estas características peculiares, autores como Brandão et al. (1991) se referiram a vereda como "comunidade seral" (em evolução); e Araujo et al. (2002) sugeriram que esta deve ser considerada como "complexo vegetacional", isto é, um tipo de vegetação formado por manchas com diferentes características estruturais e florísticas.

\section{- Geomorfologia:}

Nascimento (in Seduma 2008) avalia que o controle geológico na geomorfologia da ESEC-AE é dado em função do domo estrutural do Pipiripau esculpido em rochas do Grupo Paranoá. Segundo a autora, na área da UC há cinco compartimentos denominados Chapadas Elevadas, Rebordos, Escarpas, Planos Intermediários e Vale da Vereda:

- Chapadas Elevadas: localizam-se na porção leste da área. Apresenta reentrâncias e saliências relativas a setores mais erodidos devido ao entalhamento dos canais de drenagens afluentes da margem direita do Córrego Vereda Grande. Conforme Nascimento (in Seduma 2008), possuem declividade baixa (0 a $1^{\circ}$ nos pontos mais altos - média de 1.180), que aumenta para $2^{\circ}$ nas proximidades do contato com a unidade Rebordos. A resistência do quartzito e das couraças lateríticas representa setor mais resistente à erosão.

- Rebordos: caracterizam extensas rampas retilíneas que se prolongam desde as Chapadas Elevadas até o vale do Córrego Vereda. No local, é dividido em duas unidades: Rebordos Suaves e Rebordos Entalhados (Nascimento in Seduma 2008):

Os Rebordos Suaves localizam-se na porção sul deste compartimento entre as Chapadas Elevadas e Vale de Vereda. O contato entre tais compartimentos é suave (...). Apresentam declividade média de $2^{\circ}$ e sentido da declividade NW. Desenvolvemse sobre quartzitos $\left(\mathrm{Q}_{3}\right)$ na alta encosta e metarritmitos argilosos $\left(\mathrm{R}_{4}\right)$ na média e baixa encosta. São recobertos por latossolos e não há afloramentos rochosos, o que favorece a infiltração da água da chuva e redução do escoamento superficial. O cerrado ocupa toda a extensão da unidade (...). Não se desenvolvem canais de drenagem devido ao controle do nível de base local, que é o da Vereda de Águas Emendadas.

Os Rebordos Entalhados estão localizados na porção norte de compartimento. Possuem declividade maior que a dos Rebordos Suaves $\left(2^{\circ}\right.$ a $\left.4^{\circ}\right)$ em consequência do rebaixamento dessa rampa pelo entalhamento de alguns canais fluviais, afluentes da margem direta 
do Córrego Vereda Grande. A presença de tais canais retrata a evolução de drenagem pelo recuo de cabeceiras em decorrência do rebaixamento do nível de base do Córrego Vereda Grande (abaixo de $1000 \mathrm{~m}$ ), que nesse trecho já se apresenta como vale encaixado assimétrico. $\mathrm{O}$ traçado dos canais é paralelo à declividade (controle estrutural), com padrão da drenagem retilíneo e densidade hidrográfica baixa. Os Rebordos Suaves vão evoluir para Rebordos Entalhados na medida em que a erosão regressiva do Córrego Vereda Grande gerar o entalhamento da vereda de Águas Emendadas. Os Rebordos Entralhados são recobertos por latossolos.

No contato com as Chapadas Elevadas (contato suave) ocorrem solos concrecionários evidenciados pela presença de cascalheiras. Também ocorre afloramento de couraças nas veredas (nascente do córrego Serrinha) que entalham esta unidade (...). No limite oeste da ESEC-AE, ocorrem Gleissolos que constituem evidência pedológica de que a Vereda de Águas Emendadas possuía extensão maior que a atual (vale aberto), mas que evoluiu para vale encaixado, mantendo, entretanto, em suas margens, solos hidromórficos, típicos desse ambiente pretérito.

- Escarpas: conforme Nascimento (Seduma 2008) as Escarpas são encostas com declividades de $15^{\circ}$ a $30^{\circ}$ no setor NE da ESEC-AE entre as Chapadas Elevadas e Rebordos Dissecados (Figura 37). Ocorrem em rochas quartzíticas (anteriormente denominadas $\mathrm{Q}_{3}$ ) que afloram em alguns pontos, inclusive no contato com a unidade Chapadas Elevadas. Ainda de acordo com a autora, "nestas pequenas áreas o lençol freático aflora gerando ambientes úmidos recobertos por vegetação de gramíneas (campo úmido), delimitados por cerrados. Formam pequenas depressões abertas com fluxo superficial que tende a se concentrar a jusante no Rebordo formando canais afluentes da margem direita do Córrego Vereda Grande".

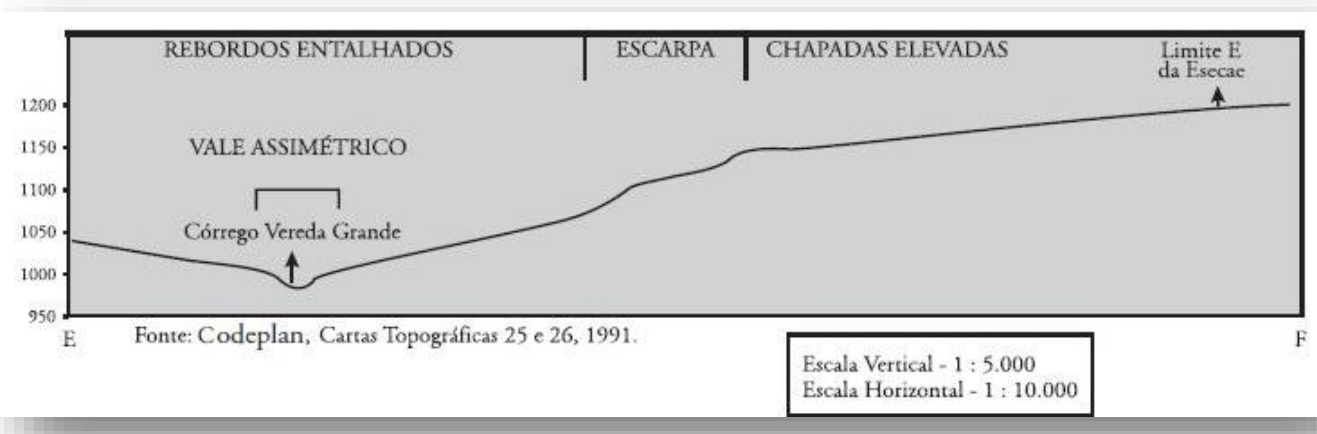

Figura 37 - Perfil da ESEC-AE no limite E. Fonte: Codeplan apud Nascimento in Seduma (2008).

\section{- Planos intermediários:}

Os Planos Intermediários ocupam grande parte da área da Estação (setores central e 
oeste). São definidos como extensas colinas rebaixadas individualizadas por vale aberto. Os topos são extensos e alongados na direção SW-NE, o que evidencia controle estrutural. Ocorrem sobre os metarritmitos argilosos (R4) a leste e psamo-pelitocarbonatados (PPC) a oeste. São recobertos por latossolos e solos concrecionários. Ocorrem morros residuais (feições de detalhe) nas proximidades do Córrego Cascarra. Nestes afloram quartzitos (R4), associados a cambissolos e Neossolos Litólicos. No setor oeste dos Planos Intermediários são identificadas lagoas que estão associadas a ocorrências de calcário da unidade litológica PPC.

O vale aberto de fundo chato que delimita as colinas rebaixadas é uma depressão alongada (controle estrutural) com declividade $<1^{\circ}$ (...). Apresenta larguras variadas e está recoberto por campo úmido, exceto acima de campos de murundus, que ocorrem em pontos diversos. Formam-se gleissolos ao longo do vale. Abaixo da cota de $1.035 \mathrm{~m}$, a depressão alongada passa a se encaixar evoluindo para um vale em V (Córrego Cascarra a S e Córrego Monjolo a SW). Comporta-se como um divisor de drenagem (Figura 38).

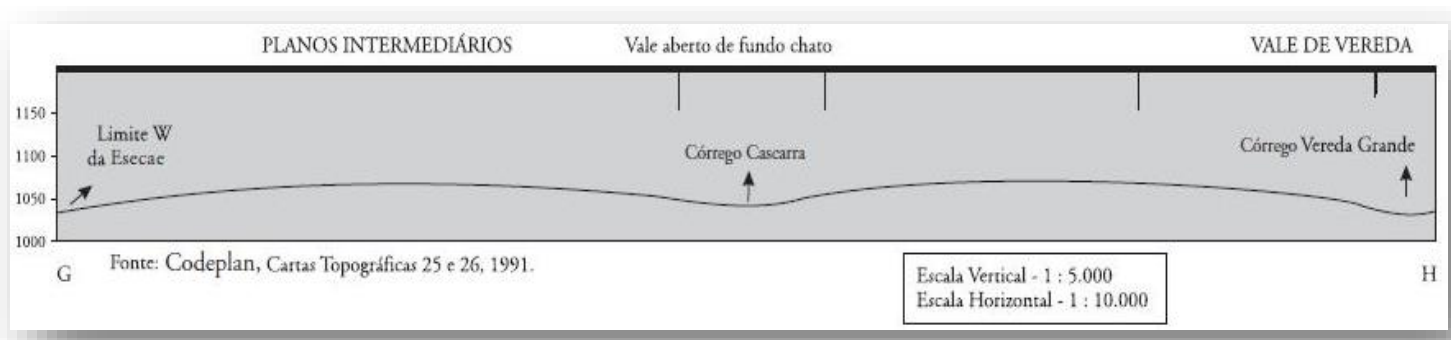

Figura 38 - Perfil da ESEC-AE entre planos intermediários e vale da vereda. Fonte: Codeplan apud Nascimento in Seduma (2008).

\section{- Vale da Vereda:}

Segundo a Resolução Conama 303/2002 (Brasil 2002), vereda e um “espaço brejoso ou encharcado, que contém nascentes ou cabeceiras de cursos d'água, onde há ocorrência de solos hidromórficos, caracterizado predominantemente por renques de buriti do brejo (Mauritia flexuosa) e outras formas de vegetação típica"

O espaço brejoso da definição acima se caracteriza como uma unidade geomorfológica descrita como vale aberto de fundo chato (...) localizado entre os limites inferiores dos Rebordos Suaves e do limite leste dos Planos Intermediários. Ocorre a altitudes de $1.032 \mathrm{~m}$ (ponto mais alto) até as proximidades de $1.025 \mathrm{~m}$, ponto esse onde a drenagem se concentra e se canaliza em vale encaixado assimétrico (controle estrutural) no sentido do Córrego Vereda Grande (N) e simétrico no sentido do Córrego Fumal (SE). Nesse contexto, o Vale da Vereda se comporta como divisor de drenagens de fluxos opostos que tende, por processo de erosão regressiva, chegar ao fenômeno de captura 
de drenagem (Figura 39).

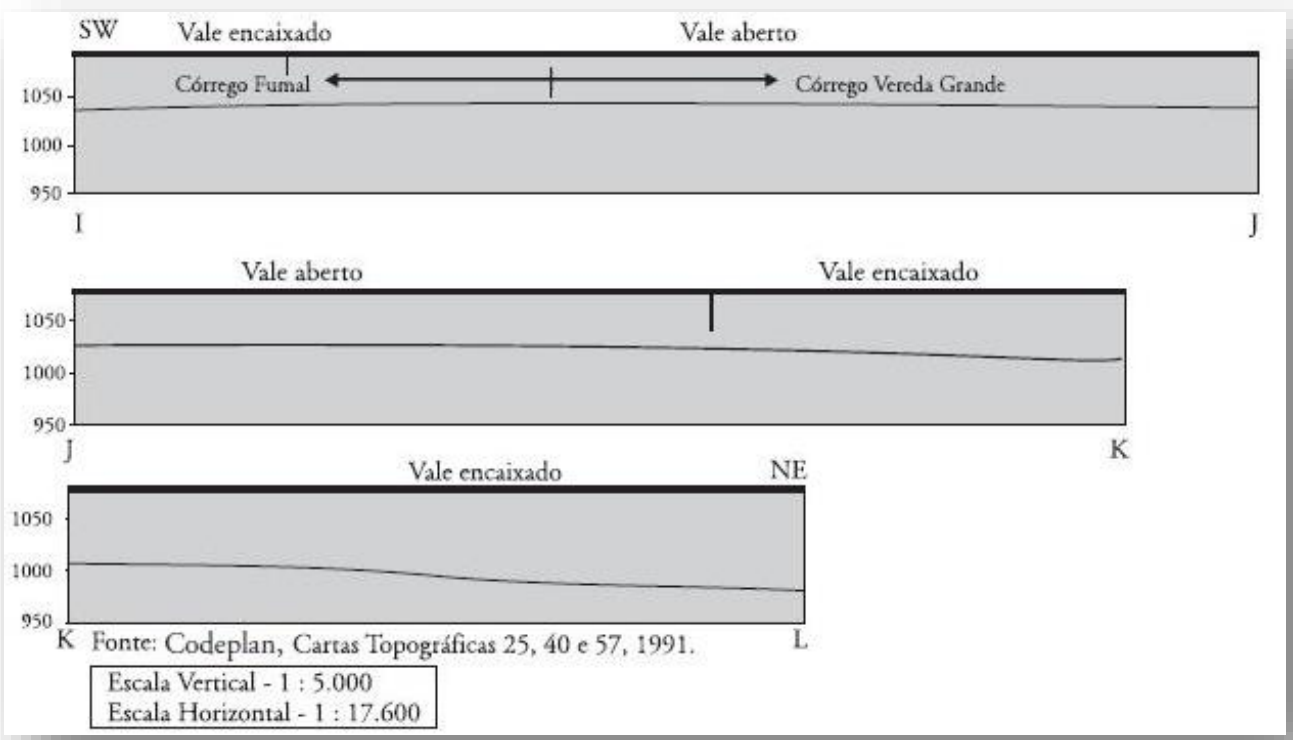

Figura 39 - Perfil da ESEC-AE de SW para NE. Representação do vale da vereda. Tendência de captura de drenagem. Fonte: Codeplan apud Nascimento in Seduma (2008).

- Clima: O clima é definido como quente e semiúmido (Figura 40), com quatro a cinco meses secos (Barberi in Seduma 2008). Segundo Lima \& Silva (in Seduma 2008): “O período de seca estende-se de abril a setembro e a estação chuvosa prolonga-se de setembro a março. A precipitação média anual situa-se entre 1.200 a 1.700 mm por ano, as temperaturas médias anuais são elevadas entre $20^{\circ}$ e $25^{\circ} \mathrm{C}$, cm médias anuais de inverno também elevadas. Quedas nas temperaturas, com pequenas oscilações ocorrem nas áreas de topografias mais elevadas e as temperaturas mínimas absolutas de inverno estão entre $10^{\circ}$ e $8^{\circ} \mathrm{C}$, com ocorrência restrita a poucos dias do ano". 


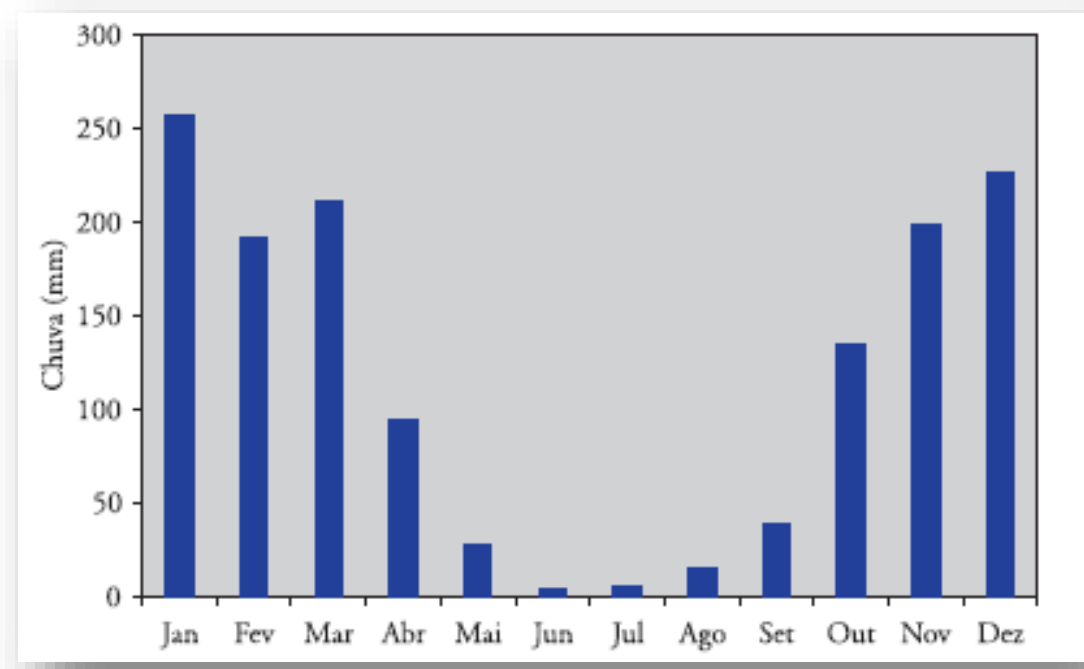

Figura 40 - Chuva média mensal na Estação Principal da Embrapa Cerrados, localizada a menos de $5 \mathrm{~km}$ da ESEC-AE. Fonte: SEDUMA (2008).

\section{- Hidrologia}

\section{- Bacia hidrográfica:}

Duas das principais bacias hidrográficas têm nascentes na ESEC-AE (Figuras 41 a 43). A Bacia do Rio Tocantins (Região Hidrográfica do Tocantins/Araguaia) e a Bacia do Rio da Prata (Região Hidrográfica do Rio Paraná). Segundo Lima \& Silva in Seduma (2008):

Parte das águas superficiais provenientes desta área atravessa o continente até encontrar o Oceano Atlântico no extremo norte do Brasil, na foz do Rio Tocantins, ao passo que outra segue para o sul até desaguar na divisa entre a Argentina e o Uruguai, no estuário do Rio da Prata. A água que verte para o norte segue um percurso de aproximadamente $2.150 \mathrm{~km}$ pela Bacia do Rio Tocantins enquanto que a que vai para o sul percorre cerca de $3.300 \mathrm{~km}$ pela Bacia do Rio da Prata, até chegar ao mar. Portanto, somando-se os trajetos, as águas superficiais geradas na Estação Ecológica Águas Emendadas contribuem para uma extensão territorial de $5.450 \mathrm{~km}$, percorrendo quatro países diferentes, o que representa uma singularidade marcante dessa área. 


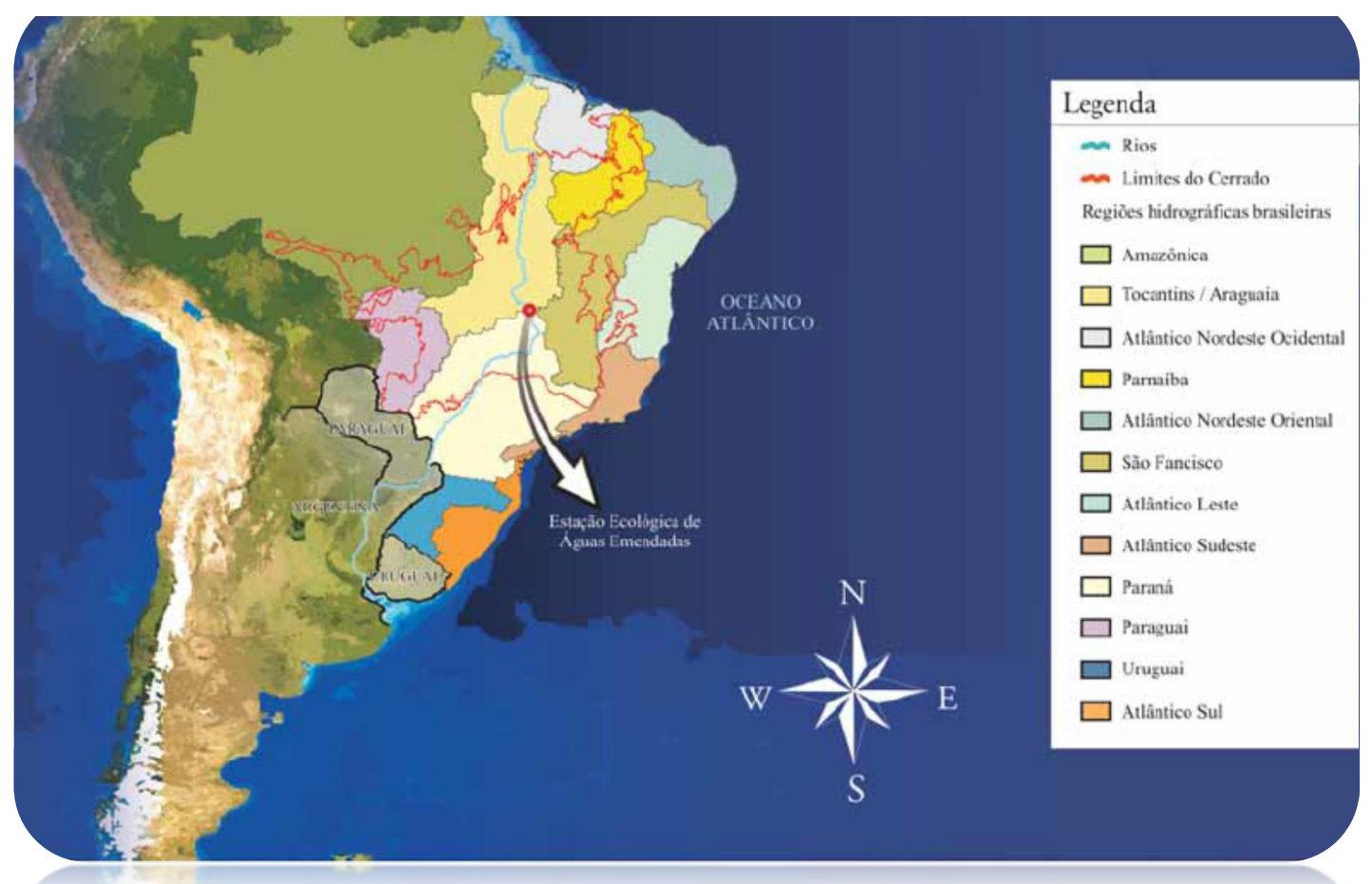

Figura 41 - A ESEC-AE insere-se em contexto de duas das maiores regiões hidrográficas brasileiras: Tocantins/Araguaia e Paraná. Fonte: SEDUMA (2008).

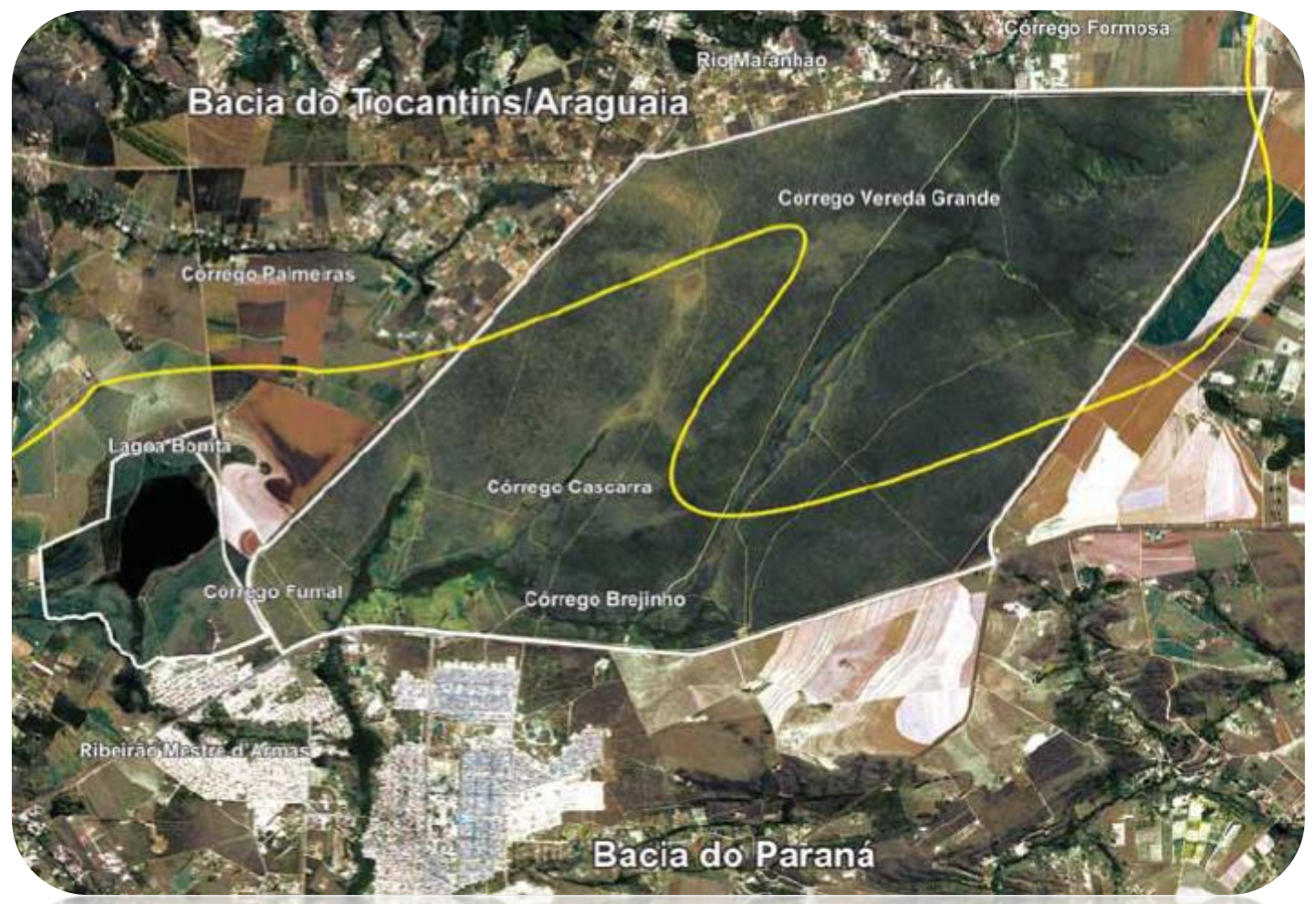

Figura 42 - Bacias hidrográficas brasileiras cujas nascentes se localizam na ESEC-AE. Ao Norte da linha amarela situa-se a Bacia do Tocantins/Araguaia. Ao Sul da linha amarela, a Bacia do Paraná. Fonte: Ribeiro et al. in Seduma (2008). 


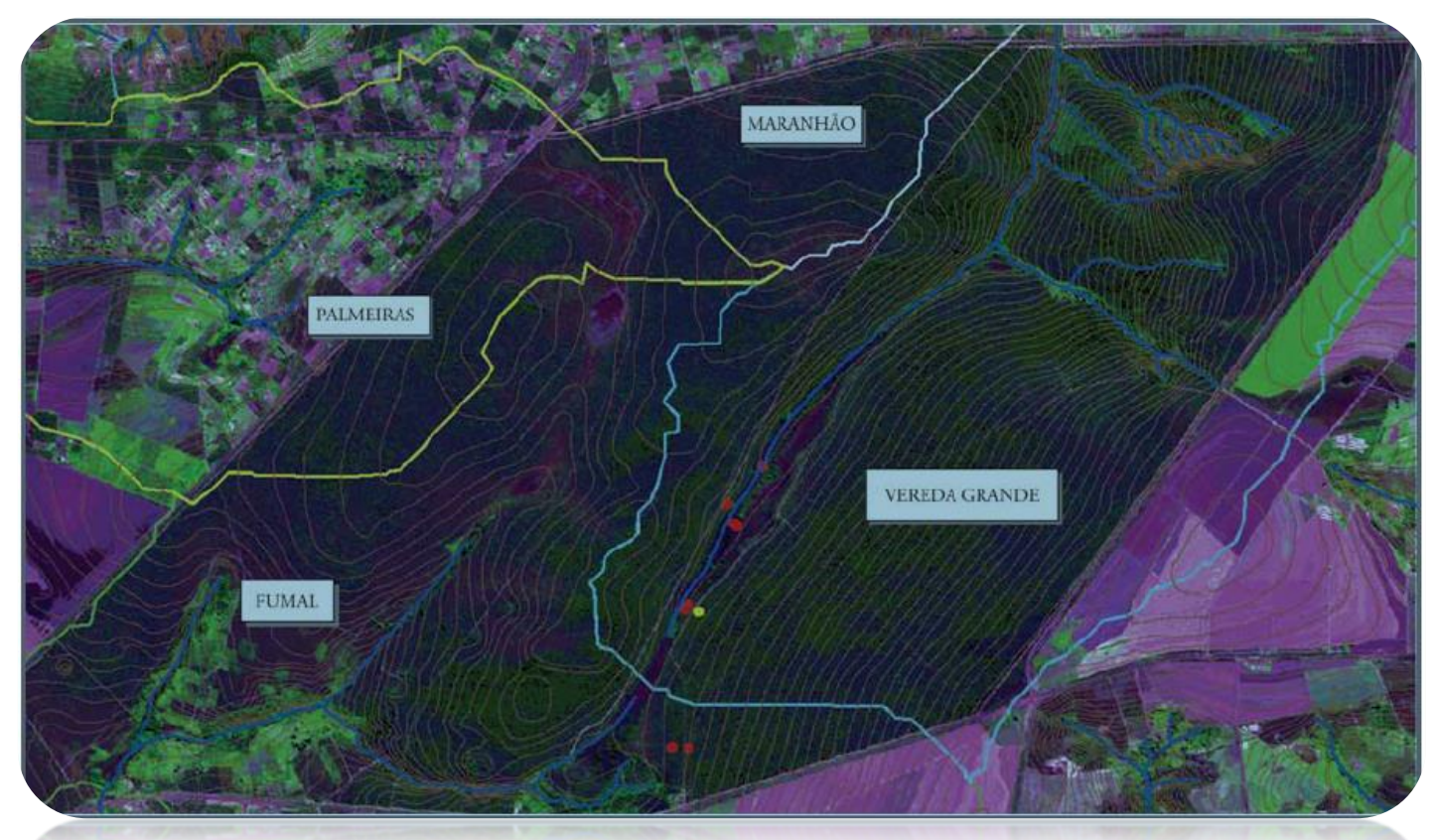

Figura 43 - Microbacias hidrográficas da ESEC-AE: As Microbacias dos Córregos Palmeiras, Maranhão e Vereda Grande integram a Bacia do Tocantins. A Microbacia Fumal integra a Bacia do Paraná. Fonte: Ribeiro et al. in Seduma (2008).

- Disponibilidade hídrica: Segundo Lima \& Silva (in Seduma 2008):

A vazão específica média na Estação Fumal BR-020 é de aproximadamente 11,2 $1 / \mathrm{s} / \mathrm{km}^{2}$, o que é plenamente compatível com os valores médios obtidos em outras estações fluviométricas da região. Em relação à variabilidade mensal da vazão específica no Córrego Fumal, é possível observar que esta varia entre 8,4 e 15,0 1/s/km², o que representa uma amplitude de apenas $6,611 / \mathrm{s} / \mathrm{km}^{2}$. Este valor é inferior aos normalmente encontrados em outras estações próximas, principalemnte naquelas com área de drenagem similar, de aproximadamente $48 \mathrm{~km}^{2}$, o que corrobora a informação de a Vereda Grande exercer efeito de regularização sobre os cursos d'água que nela se originam.

Outra hipótese levantada nesta dissertação é que a baixa variação na amplitude do Córrego do Fumal decorre de controle estrutural do aquífero, interpretado neste trabalho como fratura na direção NE-SW. Esta hipótese é corroborada pelo padrão de regularidade de vazão na nascente de fratura do Córrego Cascarra (ponto 12), tributário do Fumal, selecionada para geração de modelo conceitual (tópico 4.2.2).

- Eventuais conflitos de uso: ainda que seja uma UC de proteção integral, as atividades antrópicas desenvolvidas nos limites da ESEC-AE podem apresentar interações negativas com o meio ambiente. As atividades potencialmente mais impactantes são desenvolvidas pelas culturas agrícolas a montante (ou seja, a leste e sudeste da área). Há informações de que a propriedade rural a sudeste da área está licenciando a atividade de captação de água subterrânea para alimentação de pivô central. Há ainda a captação de água de poço tubular profundo dentro da estação, para abastecimento da sede e de 
caminhões pipa para mitigação de incêndios, como foi informado pela equipe do Ibram (Figura 44). A proximidade do poço, a montante da vereda, eventualmente pode causar impactos ambientais, dependendo da outorga autorizada. A gestão de recursos hídricos é fundamental para a manutenção dos processos naturais relacionados ao fenômeno de águas emendadas.

Os pontos de captação de água realizados pela Caesb no Córrego Fumal e Brejinho localizam-se a jusante da área da Vereda Grande. Apesar da localização diminuir efetivamente os impactos na UC, a captação vem sendo realizada sem o devido repasse de verbas à UC. O pagamento por serviços ambientais é aplicável ao caso, considerando principalmente o instrumento de cobrança pelo uso de recursos hídricos em Unidades de Conservação - Lei 9.985, de 18 de julho de 2000. (Brasil 2000):

Art. 47. O órgão ou empresa, público ou privado, responsável pelo abastecimento de água ou que faça uso de recursos hídricos, beneficiário da proteção oferecida por uma unidade de conservação, deve contribuir financeiramente para a proteção e implementação da unidade, de acordo com o disposto em regulamentação específica.

Também se considera a existência de drenos por toda a área da ESEC-AE como medida controversa. Se por um lado viabilizam o tráfego nas vias de acesso interno - o que é fundamental para a fiscalização e para a realização de pesquisas (inclusive a que possibilitou os levantamentos de campo relativos a esta dissertação), por outro lado alteram os processos de escoamento de água naturais em superfície e subsuperfície e podem eventualmente afetar as áreas de acúmulo de lâmina d'água, i.e., AUs.

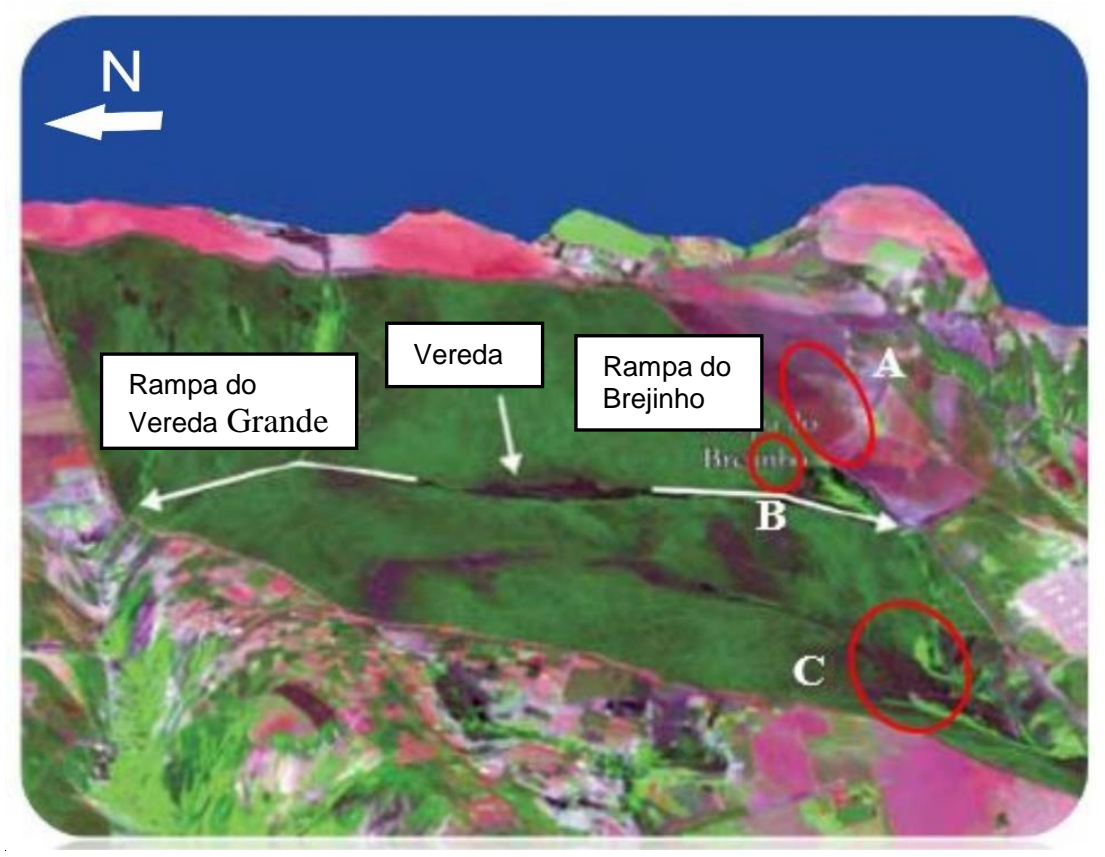

Figura 44 - Visão 3D do conjunto de drenagem das Águas Emendadas, destacando as rampas de escoamento superficial de cada drenagem. Contornos ressaltados em vermelho chamam atenção para áreas de captação de água: A. de propriedade particular com pivô central; B. de poço tubular dentro da ESEC-AE; C. da Caesb. Fonte: modificado de Baptista in Seduma (2008). 
Argumentação:

O modelo tridimensional (FIG. 44) elaborado por Baptista in Seduma (2008) auxilia a contextualização das considerações quanto ao uso dos recursos hídricos na ESEC-AE.

A visada do modelo numérico de terreno (MNT) obedece aproximadamente o sentido NW-SE. Mesmo que a determinação e detalhamento do fluxo de água subterrânea para a área ainda dependa de estudos mais aprofundados quanto à elaboração de modelo matemático, a tendência é que a carga hidráulica seja maior nos pontos mais elevados e que determine o deslocamento das linhas de fluxo, com a superfície potenciométrica do aquífero acompanhando o relevo. Assim, depreende-se que os maiores impactos potenciais advêm de atividades desenvolvidas a leste da UC (área de recarga). Ressalva-se, no entanto, que estruturas geológicas podem tornar a compreensão do fluxo de água no aquífero mais complexas e mascarar influências de fatores menos óbvios. Por esse motivo, considera-se que por precaução as influências de captação a sudeste da ESEC-AE sejam investigadas (tanto o pivô central em propriedade particular, quanto a captação de água por poço tubular dentro da própria UC). Como as nascentes submersas que alimentam a Vereda Grande são interpretadas como nascentes de falha e diante de evidências de outras nascentes determinadas por estruturas (como a do Córrego Cascarra, ponto 12 - modelo conceitual do tópico 4.2.2), é possível que o arcabouço estrutural regional/local exerça influência sobre a manutenção das feições hídricas no local. Portanto, esses impactos não podem ser sumariamente descartados. Além disso, não obstante os impactos das captações da Caesb serem potencialmente maiores a jusante da ESEC-AE, o uso do recurso hídrico deveria trazer recursos financeiros para a manutenção da UC. Por fim, os drenos distribuídos pela ESEC-AE podem exercer impactos negativos nas AUs, por drenarem os solos com elevado grau de hidromorfismo.

Projeto de criação de Plano de Manejo entre Ibram, Adasa e a UnB - já em vias de concretização - pode ser fundamental para a criação de modelo matemático que embase a adequada gestão dos recursos hídricos da UC e de sua zona de amortecimento. Acredita-se que a implementação do projeto pode esclarecer as questões acima e orientar a gestão da maneira mais sustentável possível. O foco é o uso racional dos recursos hídricos, conceito que não é impeditivo, apenas otimizador da proteção harmônica com as funções ambientais.

- Qualidade da água: a qualidade da água vem sendo monitorada pela equipe do Ibram, com a ressalva de que não há série histórica suficiente para embasar avaliações no momento. 
- Funções ecossistêmicas:

As funções ecossistêmicas da ESEC-AE são inúmeras. De maneira apenas exemplificativa citam-se as seguintes:

-Fonte de captação de água para abastecimento humano;

-Reserva da biosfera do cerrado;

-Área de Conservação de espécies ameaçadas;

-Rede hídrica de contribuição com a qualidade hídrica de duas das principais bacias hidrográficas brasileiras (Araguaia-Tocantins e Paraná);

-Local emblemático, utilizado como um dos principais critérios para a seleção da nova capital do país;

-Unidade de Educação ambiental;

-Estação de pesquisa e desenvolvimento acadêmico;

-Forte apelo socioambiental. Mobilização de reconhecimento e valorização. Fonte de inspiração para manifestações culturais e místicas.

- Singularidade do fenômeno de águas emendadas (Campos in Seduma 2008) (Tabela 12).

Tabela 12 - Síntese da singularidade do fenômeno de águas emendadas. Fonte (CAMPOS in SEDUMA).

\begin{tabular}{|c|c|c|}
\hline Feiçäo/Aspecto/Controle & Estaçáo Ecológica de Águas Emendadas & Outras águas emendadas \\
\hline Origem & $\begin{array}{l}\text { Fase precoce de desenvolvimento de campo úmido que } \\
\text { alimenta simultaneamente duas bacias hidrográficas. }\end{array}$ & $\begin{array}{l}\text { Em geral formadas pela captura de drena- } \\
\text { gens após regressáo das áreas de cabeceiras. }\end{array}$ \\
\hline Hidrologia & Divide duas regióes hidrográficas de alcance nacional. & Dividem sub-bacias ou afetam pequenas áreas de drenagem. \\
\hline Vazáo especifica & Muito elevada. & Moderada a pequena. \\
\hline Hidrogeologia & $\begin{array}{l}\text { Inclui aquilfero fréático com contribui- } \\
\text { çáo de aquíiferos fraturados profundos. }\end{array}$ & $\begin{array}{l}\text { Em geral se relacionam apenas com } \\
\text { aquifferos intergranulares rasos. }\end{array}$ \\
\hline Área de dispersáo & $\begin{array}{l}\text { Ocupa uma extensa área com gleissolos em um } \\
\text { complexo de campo úmido e veredas. }\end{array}$ & $\begin{array}{l}\text { Comumente apresentam restritas áreas de drenagem } \\
\text { que compóem o dispersor do fluxo superficial. }\end{array}$ \\
\hline Proteçio Ambiental & $\begin{array}{l}\text { Fstá totalmente no interior de uma unidade de con- } \\
\text { servaçáo ambiental de proteçáo integral. }\end{array}$ & Em geral ocupam áreas forternente antropizadas. \\
\hline
\end{tabular}

\section{- Geologia:}

O mapa geológico da ESEC-AE (Figura 45) foi aperfeiçoado e integrado às redes de drenagens, cuja distribuição na área é claramente determinada por estruturas geológicas padrões retilíneos na direção NE-SW. Na UC, ocorrem litologias no Grupo Canastra (Unidade de Fengitaquartzo Filitos), sobrepostas por mecanismos de falhas a unidades do Grupo Paranoá. A Coluna Estratigráfica do DF (Figura 46) demonstra a relação do pacote metassedimentar do DF (FreitasSilva \&Campos 1998) e contextualiza esta análise. 


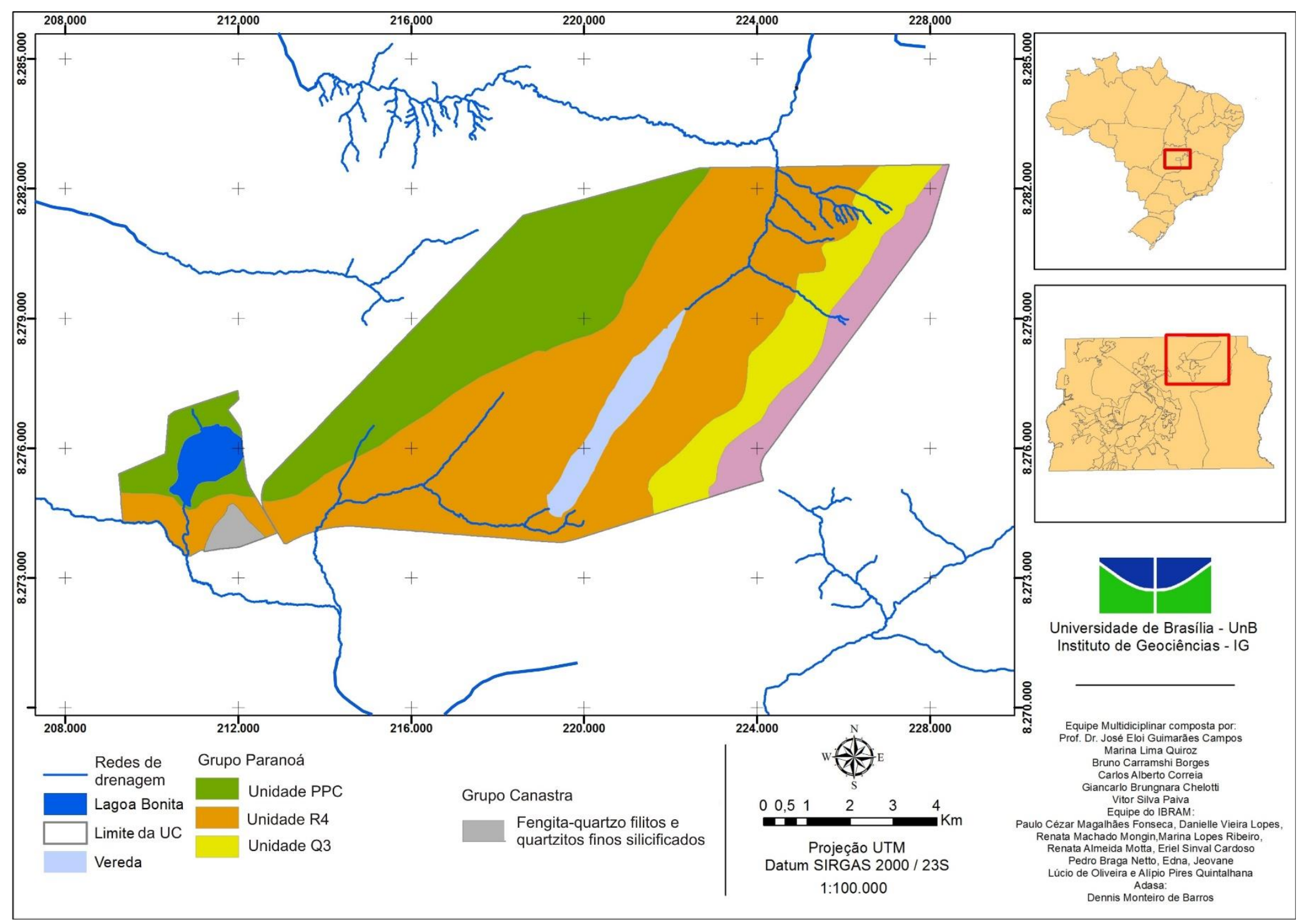

Figura 45 - Mapa geológico da ESEC-AE. Modificado com base em Moraes \& Campos (in Seduma 2008). 


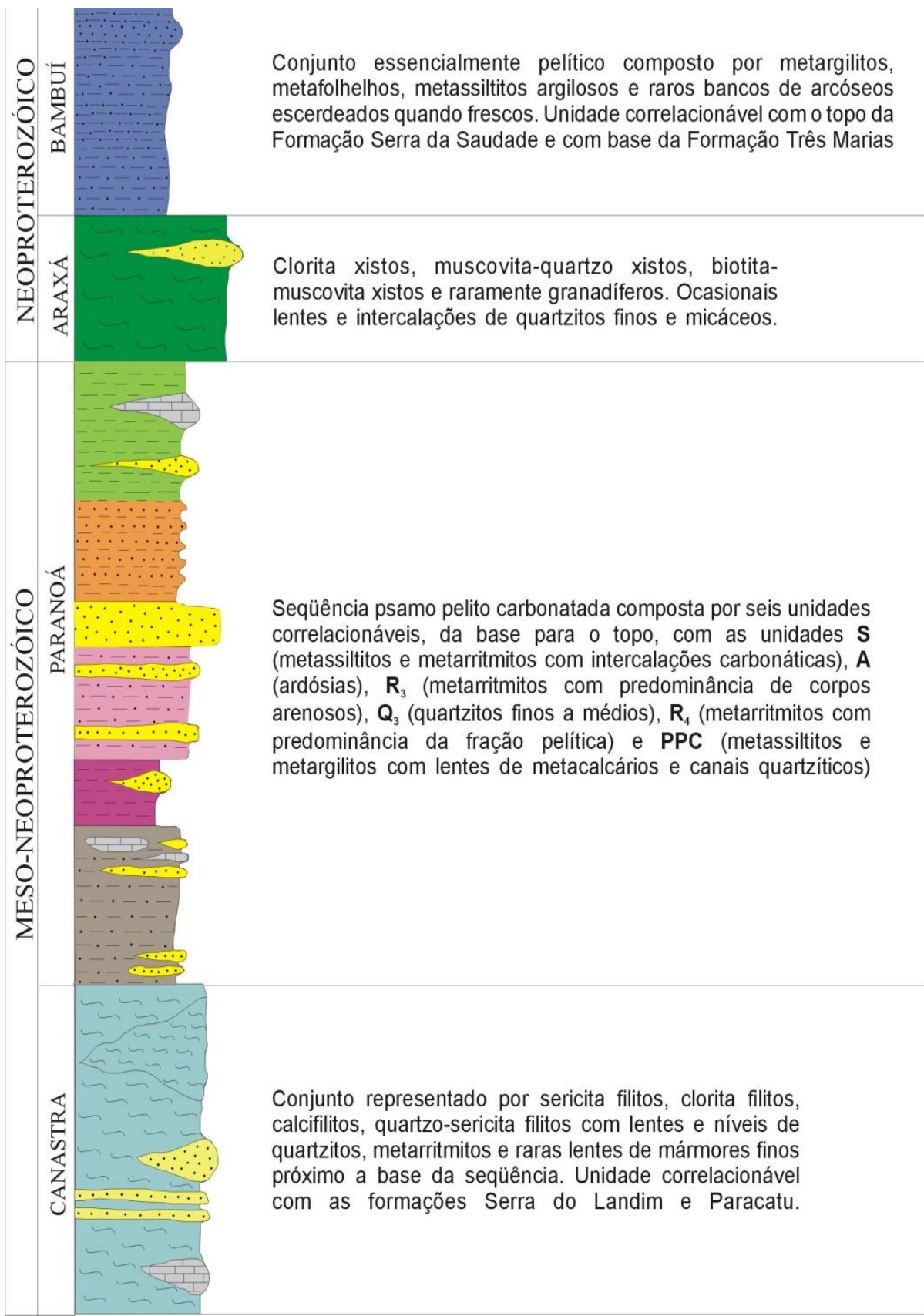

Figura 46 - Coluna estratigráfica com breve descrição litológica das unidades presentes na região do Distrito Federal. Fonte: Freitas-Silva \&Campos 1998.

Moraes e Campos in Seduma (2008) relataram que:

De acordo com o conhecimento atual, no polígono do Distrito Federal e entorno próximo ocorrem rochas atribuídas aos grupos Canastra, Paranoá, Bambuí e Araxá (...).

Os grupos Canastra e Paranoá apresentam idades de formação de cerca de um bilhão de anos, enquanto que os grupos Bambuí e Araxá foram originados entre 800 e 650 milhões de anos atrás.

No interior da Estação Ecológica e em sua zona de amortecimento ocorrem rochas atribuídas aos grupos Canastra e Paranoá.

$\mathrm{Na}$ área em estudo, o Grupo Canastra ocorre de forma restrita apenas ao sul da Lagoa 
Bonita, com raras exposições Moraes e Campos in Seduma (2008). Dois tipos de rochas estão presentes: clorita-fengita-quartzo filito e quartzito micáceo. O poço tubular profundo que abastece a sede do Centro de Informação Ambiental foi construído nessa unidade geológica. A torre de observação próxima ao Centro de Informação Ambiental também está localizada sobre quartzitos do Grupo Canastra.

Segundo Campos et al. (2013):

O Grupo Paranoá corresponde a uma sucessão psamo-pelitocarbonatada depositada em condições plataformais. A estratigrafia desse importante conjunto litoestratigráfico da Faixa de Dobramentos Brasília foi inicialmente proposta sob a designação de letras-código que inclui 11 unidades com o seguinte empilhamento estratigráfico: SM, R1, Q1, R2, Q2, S, A, R3, Q3, R4 e PPC.

Na poligonal da ESEC-AE ocorrem as Unidade R3, Unidade Q3, Unidade R4 e Unidade PPC do Grupo Paranoá, conforme é detalhado por Moraes e Campos in Seduma (2008):

\section{Unidade R3 (Metarritmito Arenoso):}

Ocorre apenas no extremo leste da área em estudo, tendo sido cartografada a partir dos contatos regionais e das características das coberturas de solos. Em cortes de estradas onde e exposta, essa unidade e representada por intercalações de camadas de rochas arenosas e de materiais argilosos. As espessuras das camadas individuais variam desde alguns centímetros até mais de 5 metros. Nas áreas de afloramentos são observadas as seguintes estruturas sedimentares (...): marcas onduladas, estratificações cruzadas, estratificações cruzadas tipo hummocky e acamamento planoparalelo. O conjunto ocorre dobrado e intensamente fraturado.

Unidade Q3 (Quartzito Médio):

Corresponde a uma faixa de direção nordeste situada na porção leste da Estação Ecológica. As melhores exposições estão presentes nas cabeceiras do Córrego Tabatinga, onde são observados quartzitos brancos e ocres, silicificados, maciços, fraturados e com granulação fina a media (...). As estruturas sedimentares observadas são estratos cruzados tabulares e acamamento pouco evidentes. (...) essa unidade pode ser mapeada mesmo sem exposições rochosas, uma vez que as coberturas regolíticas são arenosas e comumente ocorrem blocos de rocha associados.

Unidade R4 (Metarritmito Argiloso): 
(...) Intercalações regulares de material arenoso fino e material argilo-siltoso, que apresentam espessura variando de 2 a $25 \mathrm{~cm}$ e cores de tonalidade branca, vermelha e rosada (...).

$\mathrm{Na}$ porção central da unidade de conservação ocorrem amplos afloramentos associados a essa unidade. Devido a sua natureza mais plástica (quando comparado as unidades R3 e Q3), esse conjunto apresenta-se intensamente dobrado.

Unidade PPC (Psamo-pelito-carbonatada):

Esse conjunto ocorre na porção oeste e nas adjacências da Lagoa Bonita e é constituído por componentes de natureza distinta, incluindo: materiais siltico-argilosos (lamas), material arenoso (médio a grosso) e material carbonático. (...) Ocorrem lentes e camadas de quartzitos e lentes desde métricas a decamétricas, calcários e dolomitos. Em função da ampla presença de latossolos, na área em estudo não foram encontradas exposições de rochas.

\section{-Hidrogeologia:}

Os aquíferos podem ser intergranulares (porosos) e/ou fraturados. Nos aquíferos intergranulares a água é armazenada e transmitida entre os grãos. Nos fraturados, o fluxo da água é condicionado por estruturas como falhas, fraturas ou juntas em geral. Os aquíferos podem ser mistos em alguns locais, situação em que a vazão da água é excepcionalmente elevada.

No Distrito Federal, que se insere na Província Hidrogeológica Escudo Central, ocorrem os sistemas de aquíferos apresentados nas Tabelas 13 e 14. 
Tabela 13 - Caracterização simplificada dos sistemas do Domínio Intergranular do Distrito Federal. Fonte: Souza \& Campos (2001) apud Moraes \& Campos in Seduma (2008).

\begin{tabular}{|c|c|c|c|}
\hline Sistema & Solos predominantes & $\begin{array}{c}\text { Espessura } \\
\text { saturada média }\end{array}$ & $\begin{array}{l}\text { Unidades geológi- } \\
\text { cas subjacentes }\end{array}$ \\
\hline$P_{1}$ & $\begin{array}{l}\text { Latossolo vermelho de textura } \\
\text { arenosa. Areias quartzosas. }\end{array}$ & $10 \mathrm{~m}$ & $\begin{array}{c}\mathbf{Q}_{3}, \mathbf{R}_{3} \text { e quartzitos } \\
\text { da Unidade } \mathrm{S} \text {. }\end{array}$ \\
\hline $\mathrm{P}_{2}$ & $\begin{array}{l}\text { Latossolo vermelho- } \\
\text { amarelo argilosos. }\end{array}$ & $>10 \mathrm{~m}$ & $\begin{array}{l}\text { Unidades A, S, e } \\
\text { grupos Canastra } \\
\text { (leste) e Bambuí. }\end{array}$ \\
\hline$P_{3}$ & $\begin{array}{l}\text { Nitossolo e Plintossolo. } \\
\text { Localmente cambissolos. }\end{array}$ & $<15 \mathrm{~m}$ & $\begin{array}{l}\mathbf{R}_{\mathbf{d}} \text { e porçóes do } \\
\text { Grupo Araxá. }\end{array}$ \\
\hline $\mathrm{P}_{4}$ & $\begin{array}{l}\text { Cambissolos litólicos } \\
\text { e litossolos rasos. }\end{array}$ & $\begin{array}{l}\text { Solos rasos } \\
\text { ( } 1 \text { a } 2,5 \mathrm{~m} \text { ) }\end{array}$ & $\begin{array}{c}\text { PPC, grupos Ara- } \\
\text { xá e Canastra. }\end{array}$ \\
\hline
\end{tabular}

Tabela 14 - Síntese da classificação dos sistemas/subsistemas de aquíferos fraturados do DF, com respectivas vazões médias dos poços tubulares profundos. Adaptado de Campos \& Freitas Silva apud Moraes \& Campos in Seduma (2008).

\begin{tabular}{|c|c|c|c|}
\hline \multicolumn{2}{|c|}{ Aquüifero } & Vazáo Média (1/h) & $\begin{array}{c}\text { Tipos de Rochas Pre- } \\
\text { dominantes }\end{array}$ \\
\hline \multirow{5}{*}{$\begin{array}{l}\text { SISTEMA } \\
\text { PARANOÁ }\end{array}$} & Subsistema S/A & 12.000 & $\begin{array}{l}\text { Ardósias (A), metassil- } \\
\text { titos e quartzitos (S) }\end{array}$ \\
\hline & Subsistema A & 4.000 & Ardósias \\
\hline & Subsistema $\mathbf{Q}_{3} / \mathbf{R}_{3}$ & 12.000 & $\begin{array}{l}\text { Quartzitos }\left(Q_{j}\right) \text { e in- } \\
\text { tercalaçóes rítmicas de } \\
\text { quartzitos finos a médios } \\
\text { e metassiltitos }\left(R_{\text {, }}\right)\end{array}$ \\
\hline & Subsistema $\mathbf{R}_{4}$ & 6.000 & $\begin{array}{l}\text { Intercalaçóes centimétricas } \\
\text { regulares de quartzitos finos } \\
\text { e metassiltitos argilosos }\end{array}$ \\
\hline & Subsistema PPC & 9.000 & $\begin{array}{l}\text { Metassiltitos, metargilitos, } \\
\text { quartzitos e metacarbonáticas }\end{array}$ \\
\hline \multirow{2}{*}{$\begin{array}{l}\text { SISTEMA } \\
\text { CANASTRA }\end{array}$} & Subsistema F & 7.500 & Filitos \\
\hline & Subsistema F/Q/M & 33.000 & $\begin{array}{l}\text { Filitos com associaçóes de } \\
\text { quartzitos e mármores }\end{array}$ \\
\hline \multicolumn{2}{|c|}{ SISTEMA ARAXÁ } & 3.000 & Xistos \\
\hline \multicolumn{2}{|c|}{ SISTEMA BAMBUI } & 5.500 & Metapelitos de baixo grau \\
\hline
\end{tabular}


A área da Estação Ecológica de Águas Emendadas e arredores compreendem os sistemas P1, P3 e P4 do domínio intergranular, conjugados ao Sistema Paranoá (Subsistemas $\mathrm{Q}_{3} / \mathrm{R}_{3}$ e PPC) e Sistema Canastra (Subsistema F) do domínio fraturado (Figura 47).

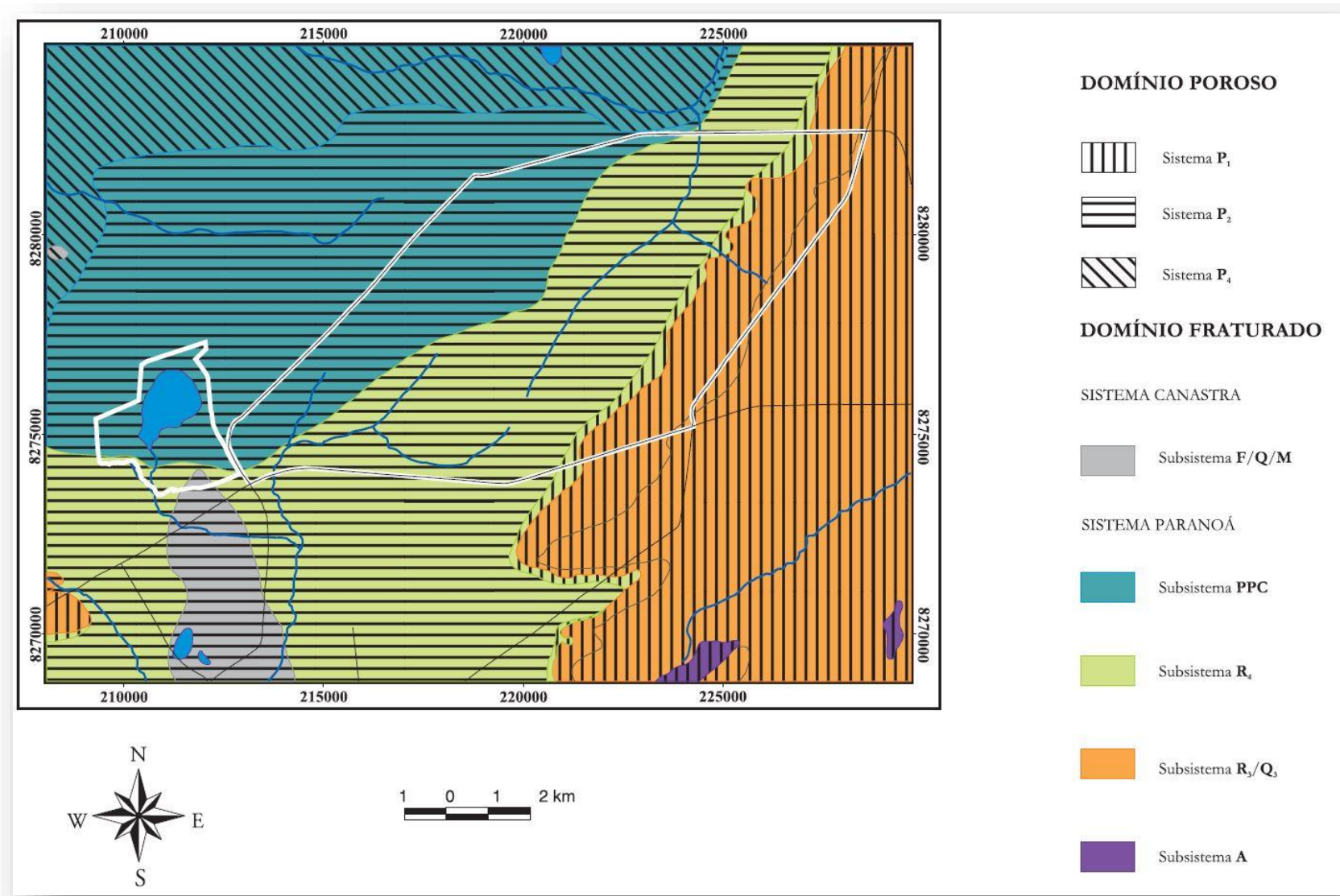

Figura 47 - Mapa hidrogeológico da ESEC-AE (MORAES \& CAMPOS in SEDUMA 2008).

De acordo com Moraes e Campos in Seduma (2008), na área da Estação Ecológica de Águas Emendadas, o Sistema P1 e o Sistema P3 são formados praticamente pelos mesmos tipos de solos, principalmente Latossolos Vermelhos de textura argilosa a média e muito profundos, Latossolos Vermelho-Amarelos de textura argilosa a média e profundos e, restritamente, areias quartzosas, Cambissolos e Gleissolos (à esta pedossequência esta dissertação acrescenta Paleogleissolos e Latossolos Amarelos). No entanto, diferem quanto ao substrato rochoso, onde o sistema P1 encontra-se sobre o subsistema fraturado R3/Q3, de maior importância hidrogeológica, e o sistema P3 encontra-se sobre os subsistemas fraturados R4 e PPC.

Campos \& Freitas-Silva (1998) consideram como Sistema P1 aquele composto por Latossolos Vermelho-Amarelos de textura arenosa e, mais restritamente, por Neossolos Quartzarênicos, apresentando condutividade hidráulica vertical com valores da ordem de $10^{-6}$ a $10^{-5} \mathrm{~m} / \mathrm{s}$ na porção rasa do solo, os quais tendem a uma pequena diminuição em profundidades crescentes. A espessura saturada é em média de 10 a 15 metros.

O sistema P3 consiste de latossolos vermelhos argilosos e cambissolos, com espessuras 
inferiores a 15 metros e condutividade hidráulica entre $1,4 \times 10^{-7}$ e 2,3 x $10^{-8} \mathrm{~m} / \mathrm{s}$ (os valores menores são observados a partir de $200 \mathrm{~cm}$ de profundidade). Quando os solos são ricos em fragmentos rochosos, a condutividade hidráulica pode ser incrementada (Moraes \& Campos in Seduma 2008).

O Sistema P4 compreende cambissolos litólicos e litossolos rasos, comumente com fragmentos líticos de rochas pelíticas, onde a condutividade hidráulica e a transmissividade são muito baixas. Em certas regiões não há zona saturada no domínio poroso (Moraes \& Campos in Seduma 2008). A associação com a pequena espessura dos cambissolos e relevo movimentado conferem ao sistema $\mathrm{P} 4$ as piores condições de recarga.

O Domínio Fraturado na ESEC-AE é formado pelas rochas metassedimentares dos grupos Paranoá e Canastra. O Sistema Paranoá subdivide-se na área nos subsistemas Q3/R3, R4 e PPC e o Sistema Canastra se restringe a F/Q/M nas proximidades da Lagoa Bonita. Assim, os reservatórios de água subterrânea estão restritos a porosidade secundaria das rochas, ou seja, suas fissuras e fraturas (juntas e falhas), que são o resultado da quebra de coesão da rocha quando submetida a esforços tensionais no domínio rúptil da crosta. A capacidade dos aquíferos fraturados de armazenar água está relacionada a densidade, a abertura e a conectividade dessas descontinuidades (Moraes \& Campos in Seduma 2008).

\section{- Pedologia:}

O levantamento pedológico de reconhecimento em escala 1:100.000, realizado pelo Serviço Nacional de Levantamento de Solos (EMBRAPA 1978) foi utilizado como por Lacerda (in Seduma 2008) para proposição de mapa de pedoformas para a área da ESEC-AE (Figura 48). A autora mapeou as principais classes de solo do DF na área e os relacionou com a geomorfologia.

O trabalho de classificação dos solos realizado para o citado mapeamento de pedoformas (Lacerda in Seduma 2008) foi criterioso e envolveu as devidas análises químicas, conforme as especificações do SiBCS. Foi a partir dessa classificação dos solos que a equipe que apoiou esta dissertação refinou o mapeamento pedológico e identificou duas categorias de solos que até então não haviam sido consideradas: o Paleogleissolo e o Latossolo Amarelo. A relação pedogenética pode então ser descrita pela seguinte pedossequência (amostras coletadas na ESEC-AE registradas na sequência fotográfica da Figura 49): Latossolo Vermelho (LV); Latossolo Vermelho-Amarelo (LVA); Latossolo Amarelo (LA); Paleogleissolo (PGx); e Gleissolo Háplico (Gx). Essa pedossequência tem grande significado genético. A partir da análise de evolução das características físico-químicas do solo, as relações espaço-temporais e paleoambientais puderam ser integradas (discussão do tópico 4.1.2 e produto de delineação espaço-temporal do tópico 4.1.3). 


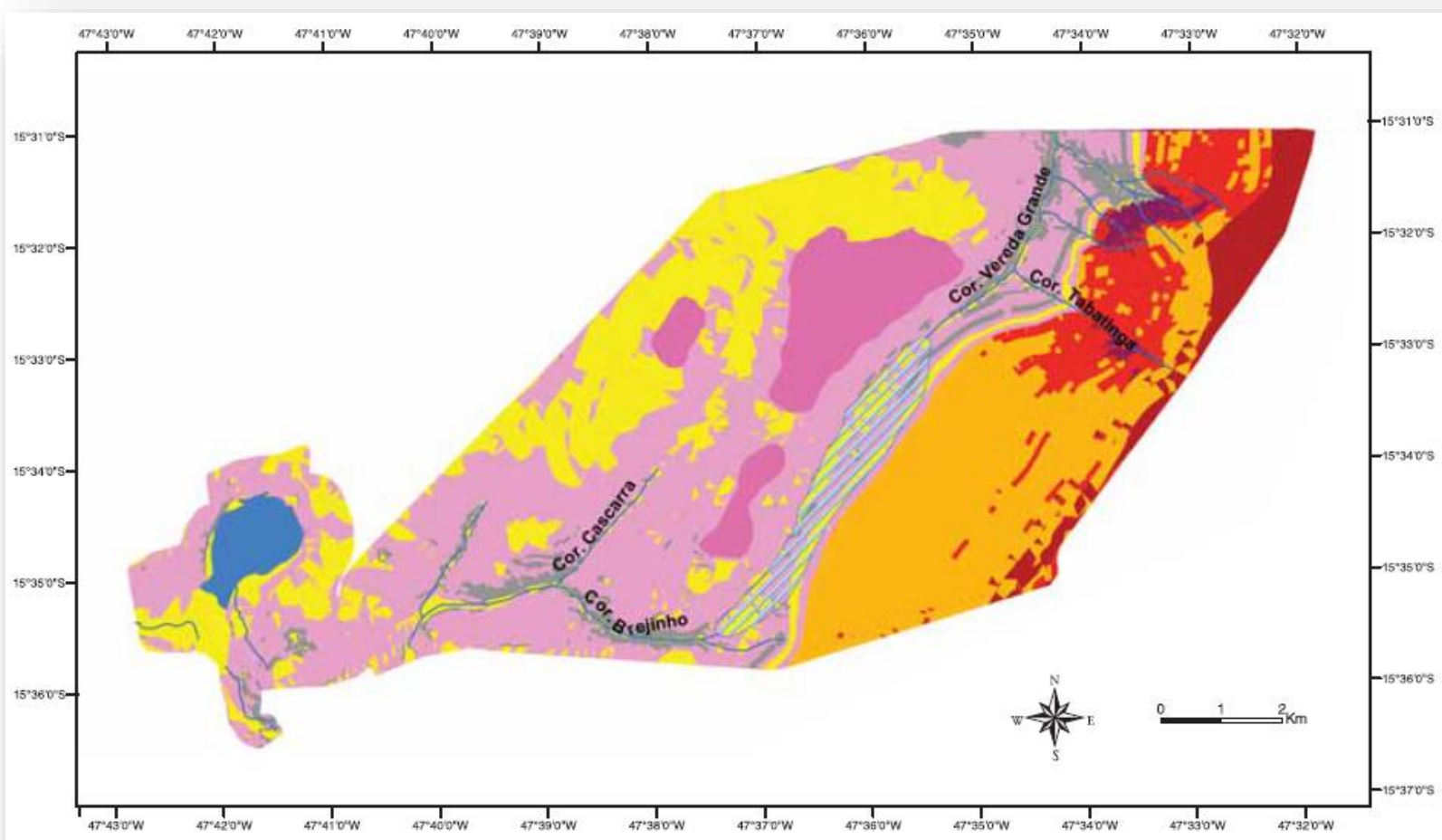

PEDOFORMAS ESECAE Rebordo Entalhado: LVA+LVAf

DIX Vale da Vereda: GX, GM, OX

Chapadas Elevadas, plano a suave ondulado: $\mathrm{LV}+\mathrm{RQ}+\mathrm{LVA}$

Plano Intermediário, suave ondulado: LV+LVA

Morros Residuais: $\mathrm{CX}+\mathrm{RL}+\mathrm{AR}+\mathrm{CFe}$

$\square$ Encostas Vales: $\mathrm{FX}+\mathrm{FF}+\mathrm{LVAf}+\mathrm{CX}$

Escarpa: $\mathrm{CX}+\mathrm{RL}+\mathrm{AR}$

-

Figura 48 - Mapa de pedoformas segundo Lacerda (in SEDUMA 2008).
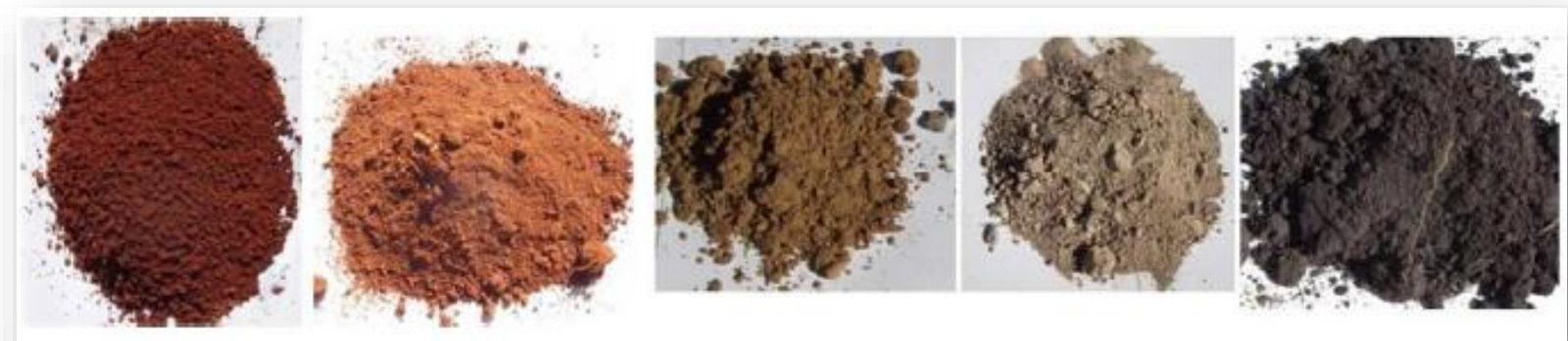

Figura 49 - Registro fotográfico de amostras coletadas na ESEC-AE representativas da pedossequência: Latossolo Vermelho; Latossolo Vermelho-Amarelo; Latossolo Amarelo; Paleo Gleissolo; e Gleissolo.

Em suma, o solo registra as modificações físico-químicas promovidas pelos processos de exposição ao intemperismo e a condições mais ou menos oxidantes. De maneira geral, a maior parte dos solos do Distrito Federal é resultado de processos de oxidação. No entanto, parte da ESEC-AE foi submetida a ambientes redutores, em contexto de AUs ao longo do tempo (tópico 4.1.2), o que os sujeitou a elevado grau de hidromorfismo. À medida que a configuração mudou com o longo período de estiagem no holoceno inicial, gradualmente os Gleissolos deixaram de ser submetidos à saturação por água e se tornaram Paleogleissolos. A partir de então, paulatinamente 
oxidaram para Latassolos Amarelos e Latossolos Vermelho-Amarelos. Latossolos vermelhos são o estágio mais avançado de oxidação.

Esta avaliação embasa a constatação de redução dimensional das áreas úmidas da ESECAE de maneira moderada na escala do tempo geológico. As propriedades de gleização dos Paleogleissolos são obliteradas à medida que o solo é submetido a condições de oxidação e exposição ao intemperismo e a drenagem mais eficiente no perfil. A caracterização da pedossequência contribui com a relevante reconstrução do significado pedogenético.

\subsubsection{Produto: modelos conceituais}

Os modelos conceituais são úteis para amarrar os produtos da determinação espaçotemporal das feições hídricas com a sua caracterização. Baptista in Seduma (2008) representou o contexto geomorfológico da área com modelo digital de terreno (Figura 50) e aplicou ao mapa geológico da área exagero vertical para ressaltar as suas feições físicas (Figura 50). Esta dissertação acrescenta ao modelo do autor seis feições hídricas representativas do cenário atual, devidamente determinadas especialmente e caracterizadas (Tabelas 15 a 20 e Figuras 51 a 63). Por meio da proposta de modelos conceituais, busca-se contribuir com a necessária compreensão dos processos e da dinâmica hídrica para a aplicação adequada dos instrumentos de proteção.

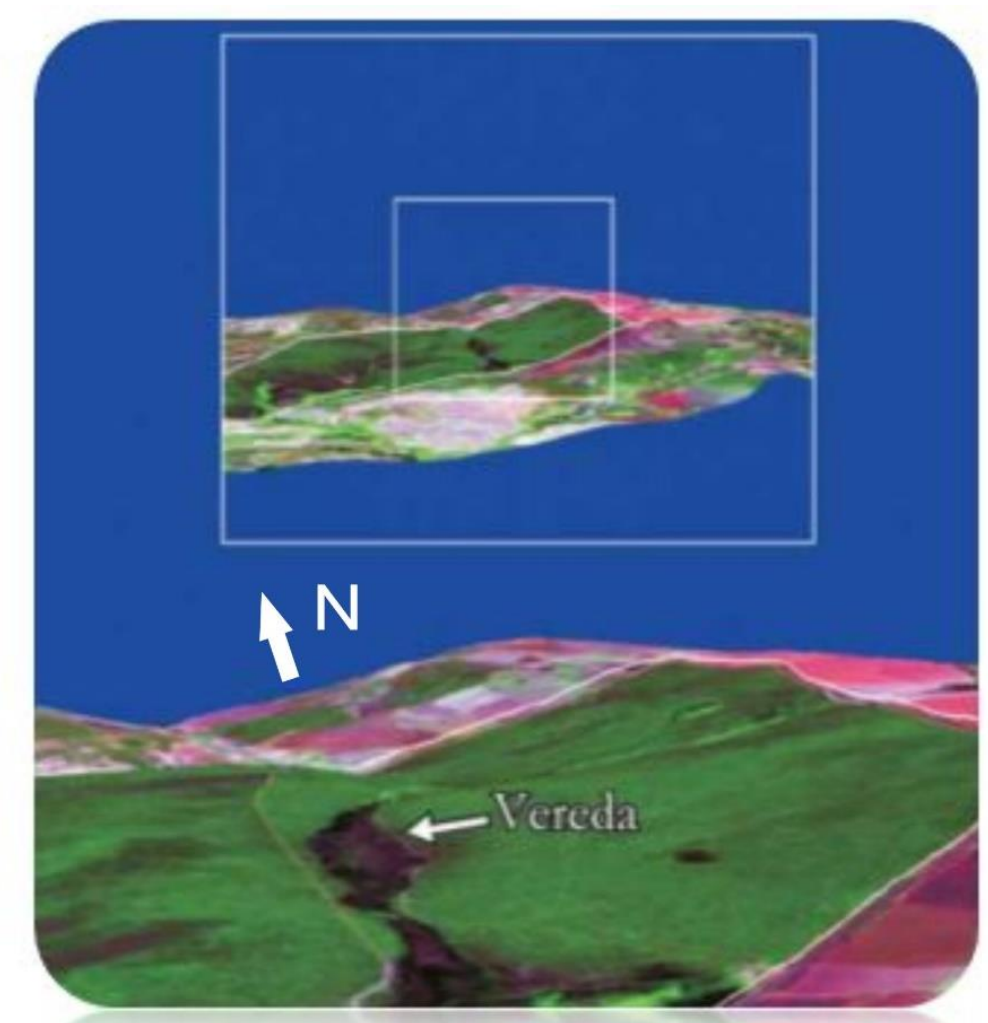

Figura 50 - Modelo tridimensional da ESECAE com foco no vale da vereda. Fonte: Baptista in SEDUMA (2008). 


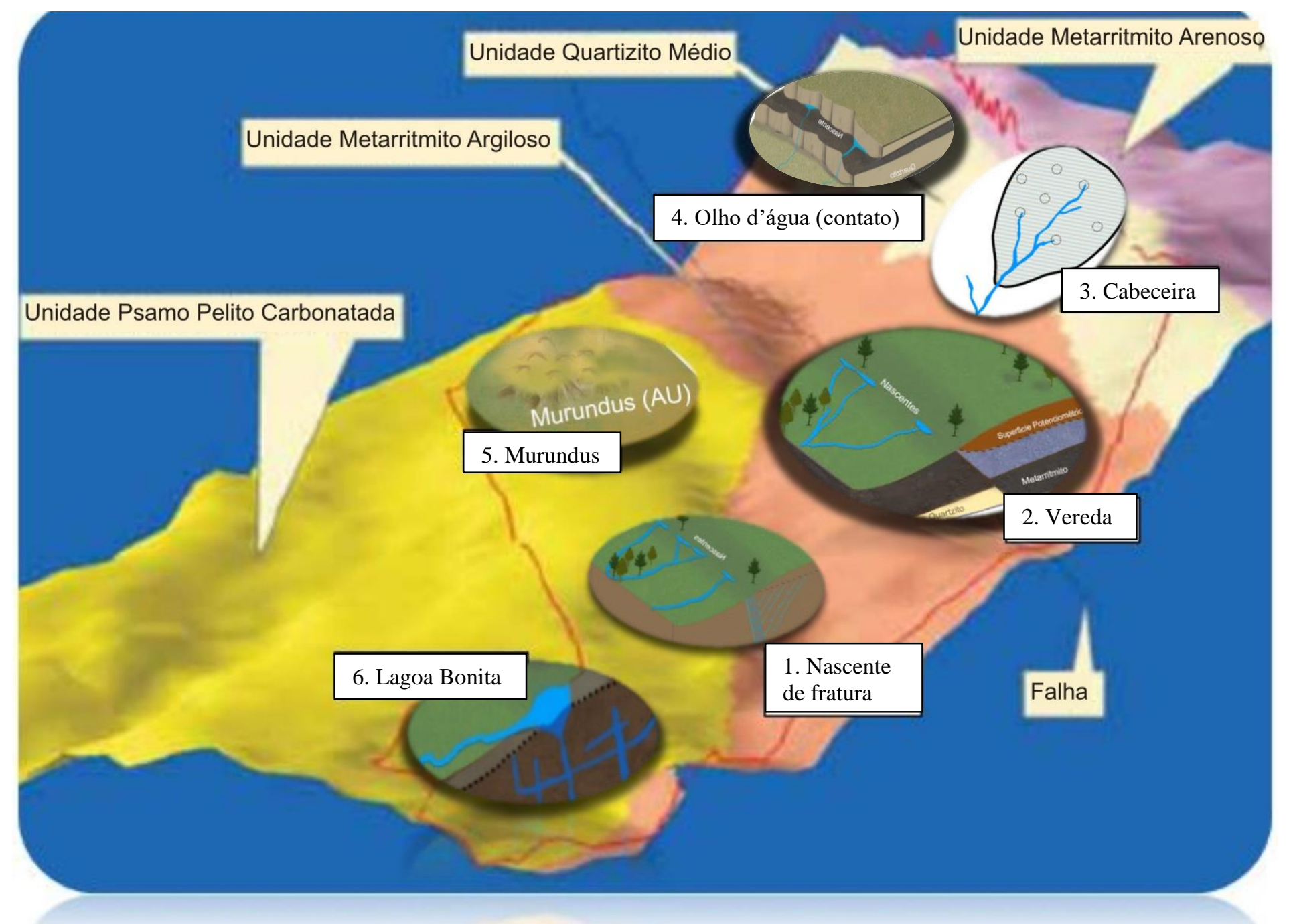

Figura 51 - Contexto geral da ESEC-AE em modelo tridimensional com exagero vertical, modificado de Baptista in SEDUMA (2008). Os modelos conceituais discutidos ao longo desta dissertação são plotados esquematicamente em sua localização na UC: 1 . Nascente de fratura; 2 . Vereda; 3 . Cabeceira; 4. Olho d'água (contato); 5. Campos de murundus; 6. Lagoa Bonita. 
Tabela 15 - Síntese do Modelo Conceitual - Nascente de fratura (1).

\begin{tabular}{|c|c|c|}
\hline Registros de Campo (Determinação) & Ilustração do Modelo & Descrição (Caracterização) \\
\hline $\begin{array}{l}\text { Figura } 52 \text { - Nascente de fratura do } \\
\text { Córrego Cascarra. Vazão de água é } \\
\text { constante ao longo do ciclo hidrológico } \\
\text { anual, segundo informações da equipe de } \\
\text { monitoramento do Ibram. Fonte d'água } \\
\text { (conforme conceito proposto por esta } \\
\text { dissertação) contribui à captação da } \\
\text { Caesb. Fonte: arquivo pessoal. }\end{array}$ & $\begin{array}{l}\text { Figura } 53 \text { - Modelo de nascente, cujo fluxo de água é condicionado } \\
\text { pelo plano de fratura. Sobreposto ao bloco diagrama perfil de vale } \\
\text { aberto de fundo chato do Córrego Cascarra. }\end{array}$ & $\begin{array}{l}\text { Bioma: Cerrado } \\
\text { Vegetação: Mata de galeria e } \\
\text { vegetação exótica } \\
\text { (bananeira). } \\
\text { Geomorfologia: vale aberto } \\
\text { de fundo chato, com controle } \\
\text { estrutural (Nascimento in } \\
\text { Seduma 2008). } \\
\text { Clima: quente e semiúmido, } \\
\text { com quatro a cinco meses } \\
\text { secos (maio a setembro). } \\
\text { Hidrologia: } \\
\text {-Região Hidrográfica do } \\
\text { Paraná; Bacia Hidrográfica } \\
\text { do Rio da Prata; Microbacia } \\
\text { do Fumal. (Ribeiro et. al in } \\
\text { Seduma 2008). } \\
\text { Geologia: Formação Córrego } \\
\text { do Sansão (Campos et al. } \\
\text { 2013). } \\
\text {-Hidrogeologia: Domínio } \\
\text { Fraturado Subsistema R } 4 \\
\text { (Moraes \& Campos in } \\
\text { Seduma 2008). } \\
\text { Pedologia: Latossolo } \\
\text { Vermelho-Amarelo }\end{array}$ \\
\hline
\end{tabular}


Tabela 16 - Síntese do Modelo Conceitual - Vereda Grande(2)

\begin{tabular}{|c|c|c|}
\hline Registros de Campo (Determinação) & Ilustração do Modelo & Descrição (Caracterização) \\
\hline $\begin{array}{l}\text { Pontos 5, 6, 22, 32, 45, 50, 51; 52, } 64 \mathrm{e} \\
65 \\
\text { Coordenadas: } 23 \text { L (FIG. 53) } \\
\left\{\begin{array}{l}221.040 \mathrm{~m} \mathrm{E} \\
8.279 .560 \mathrm{~m} \mathrm{~S}\end{array}\right. \\
\text { (Sirgas 2000. Projeção UTM) }\end{array}$ & $\begin{array}{l}\text { Fascente de Falha } \\
\text { Figura } 55 \text { - Modelo de nascentes submersas de vereda, cujo } \\
\text { fluxo é controlado por plano de falha. Sobreposto ao bloco- } \\
\text { diagrama, perfil da passagem do vale encaixado do Córrego } \\
\text { Brejinho } \rightarrow \text { vale aberto da vereda } \rightarrow \text { vale encaixado do } \\
\text { Córrego Vereda Grande no sentido SW-NE. }\end{array}$ & $\begin{array}{l}\text { Bioma: Cerrado. } \\
\text { Vegetação: Complexo } \\
\text { vegetacional. Transição de } \\
\text { vereda/buritizal/mata } \\
\text { alagada/mata de galeria, de } \\
\text { acordo com o encaixe do vale. } \\
\text { Geomorfologia: vale da } \\
\text { vereda, em transição para vale } \\
\text { encaixado assimétrico. } \\
\text { (Nascimento in Seduma 2008). } \\
\text { Clima: quente e semiúmido, } \\
\text { com quatro a cinco meses } \\
\text { secos (maio a setembro). } \\
\text { Hidrologia: } \\
\text {-Região Hidrográfica do } \\
\text { Tocantins/Araguaia; Bacia } \\
\text { Hidrográfica do Tocantins; } \\
\text { Microbacia Vereda Grande. } \\
\text { (Ribeiro et. al in Seduma } \\
\text { 2008). } \\
\text { Geologia: Formação Córrego } \\
\text { do Sansão (Campos et al. } \\
\text { 2013). } \\
\text {-Hidrogeologia: Domínio } \\
\text { Fraturado Subsistema R4 } \\
\text { (Moraes \& Campos in Seduma } \\
\text { 2008). } \\
\text { Pedologia: Gleissolo e } \\
\text { Paleogleissolo. }\end{array}$ \\
\hline
\end{tabular}


Tabela 17 - Síntese do Modelo Conceitual - Cabeceira (3)

\begin{tabular}{|c|c|c|}
\hline Registros de Campo (Determinação) & Ilus & Descrição (Caracterização) \\
\hline $\begin{array}{l}\text { Figura } 56 \text { - Contexto de cabeceira: área } \\
\text { úmida composta por Gleissolo Háplico, } \\
\text { com olhos d'água e nascentes difusas. } \\
\text { Não há afloramentos rochosos, o que } \\
\text { favorece a infiltração da água da } \\
\text { chuva e redução do escoamento } \\
\text { superficial. Na porção da chapada } \\
\text { elevada há níveis petroplínticos, que } \\
\text { indicam diferentes elevações anteriores } \\
\text { da superfície potenciométrica. Fonte: } \\
\text { arquivo pessoal. }\end{array}$ & $\begin{array}{l}\text { Figura } 57 \text { - Modelo de cabeceira. Nascentes e olhos d'água do } \\
\text { Córrego Tabatinga. O nível da superfície potenciométrica (SP) } \\
\text { se desloca ao longo do ciclo hídrico e determina a surgência em } \\
\text { olhos d'água. Nascente é o ponto de intersecção da SP no terreno } \\
\text { de menor elevação ao longo dos ciclos hídricos. O Gleissolo } \\
\text { Háplico é o critério identificador da AU. }\end{array}$ & $\begin{array}{l}\text { Bioma: Cerrado } \\
\text { Vegetação: Mata de galeria } \\
\text { com presença de buritis. } \\
\text { Geomorfologia: entre } \\
\text { chapadas elevadas e rebordo } \\
\text { suave (Nascimento in } \\
\text { Seduma 2008). } \\
\text { Clima: quente e semiúmido, } \\
\text { com quatro a cinco meses } \\
\text { secos (maio a setembro). } \\
\text { Hidrologia: } \\
\text {-Região Hidrográfica do } \\
\text { Tocantins/Araguaia; Bacia } \\
\text { Hidrográfica do Tocantins; } \\
\text { Microbacia Vereda Grande. } \\
\text { (Ribeiro et. al in Seduma } \\
\text { 2008). } \\
\text { Geologia: entre Fm. Córrego } \\
\text { do Sansão e Fm. Ribeirão } \\
\text { Contagem (Campos et al. } \\
\text { 2013). } \\
\text {-Hidrogeologia: Domínio } \\
\text { Fraturado Subsistema R } 4 \\
\text { (Moraes \& Campos in } \\
\text { Seduma 2008). } \\
\text { Pedologia: Gleissolo } \\
\text { Háplico. }\end{array}$ \\
\hline
\end{tabular}


Tabela 18 - Síntese do Modelo Conceitual - Olho d'Água de contato (4)

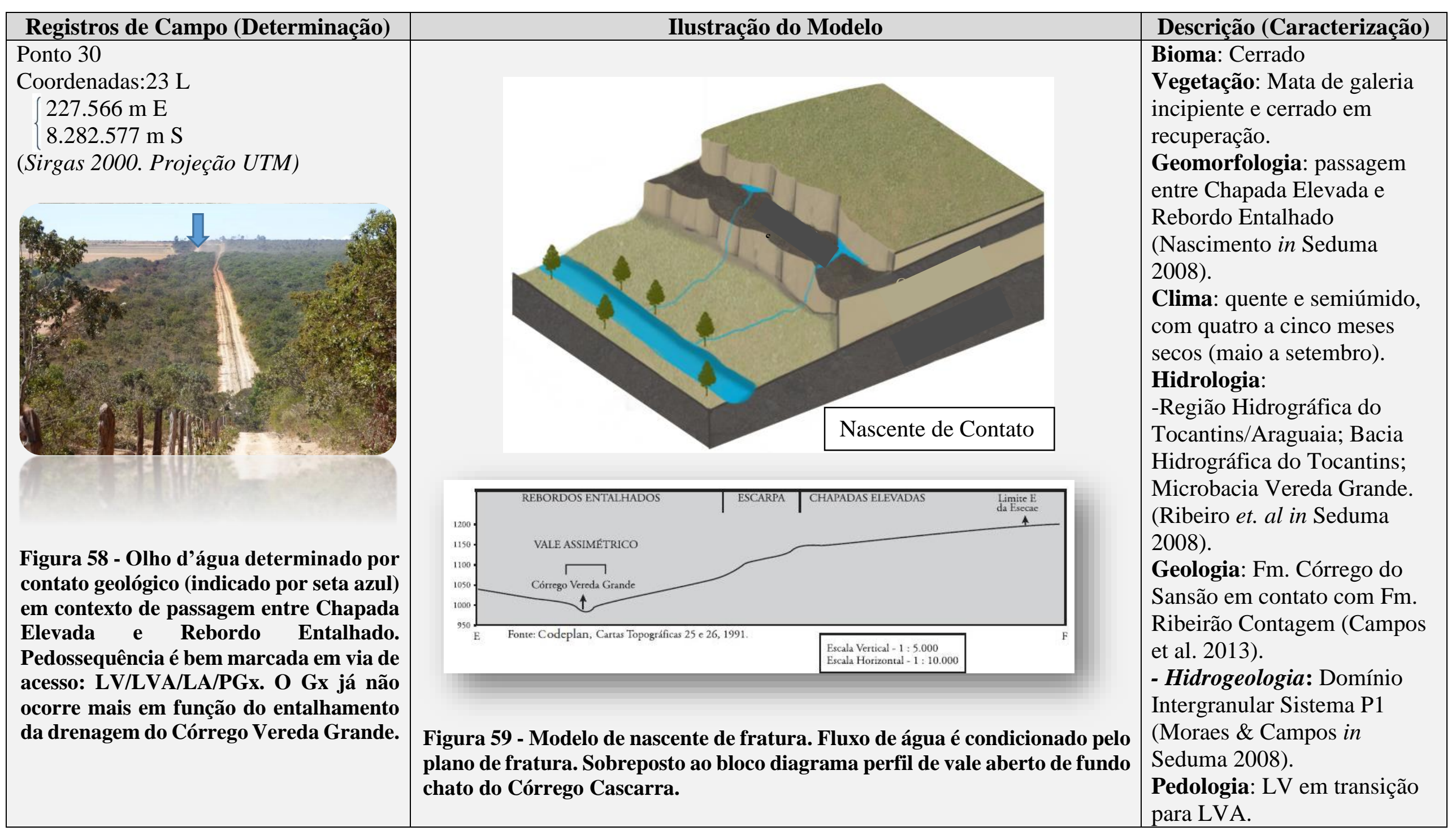


Tabela 19 - Síntese do Modelo Conceitual - Murundus (5)

\begin{tabular}{|c|c|c|}
\hline Registros de Campo (Determinação) & Ilustração do Modelo & Descrição (Caracterização) \\
\hline $\begin{array}{l}\text { Figura } 60-\text { Murundus. Pequenos } \\
\text { morrotes com vegetação arbustiva em } \\
\text { meio a campo limpo úmido. Fonte: } \\
\text { arquivo pessoal. }\end{array}$ & $\begin{array}{l}\text { MUIUIOUS }(A \cup) \\
\text { Figura } 61 \text { - Modelo de murundus. Elevações no } \\
\text { terreno são consideradas AUs. O principal campo de } \\
\text { Murundus da ESEC-AE localiza-se na porção NW } \\
\text { da área. }\end{array}$ & $\begin{array}{l}\text { Bioma: Cerrado } \\
\text { Vegetação: campo limpo } \\
\text { úmido com vegetação lenhosa } \\
\text { sobre morrotes. } \\
\text { Geomorfologia: plano } \\
\text { intermediário (Nascimento in } \\
\text { Seduma 2008). } \\
\text { Clima: quente e semiúmido, } \\
\text { com quatro a cinco meses } \\
\text { secos (maio a setembro). } \\
\text { Hidrologia: } \\
\text {-Região Hidrográfica do } \\
\text { Tocantins/Araguaia; Bacia } \\
\text { Hidrográfica do Rio } \\
\text { Tocantins; Microbacia do } \\
\text { Fumal. (Ribeiro et. al in } \\
\text { Seduma 2008). } \\
\text { Geologia: Formação Córrego } \\
\text { do Sansão (Campos et al. } \\
\text { 2013). } \\
\text {-Hidrogeologia: Domínio } \\
\text { Intergranular Sistema P3 } \\
\text { (Moraes \& Campos in } \\
\text { Seduma 2008). } \\
\text { Pedologia: Paleogleissolo } \\
\text { Háplico. }\end{array}$ \\
\hline
\end{tabular}


Tabela 20 - Síntese do Modelo Conceitual - Lagoa Bonita (6)

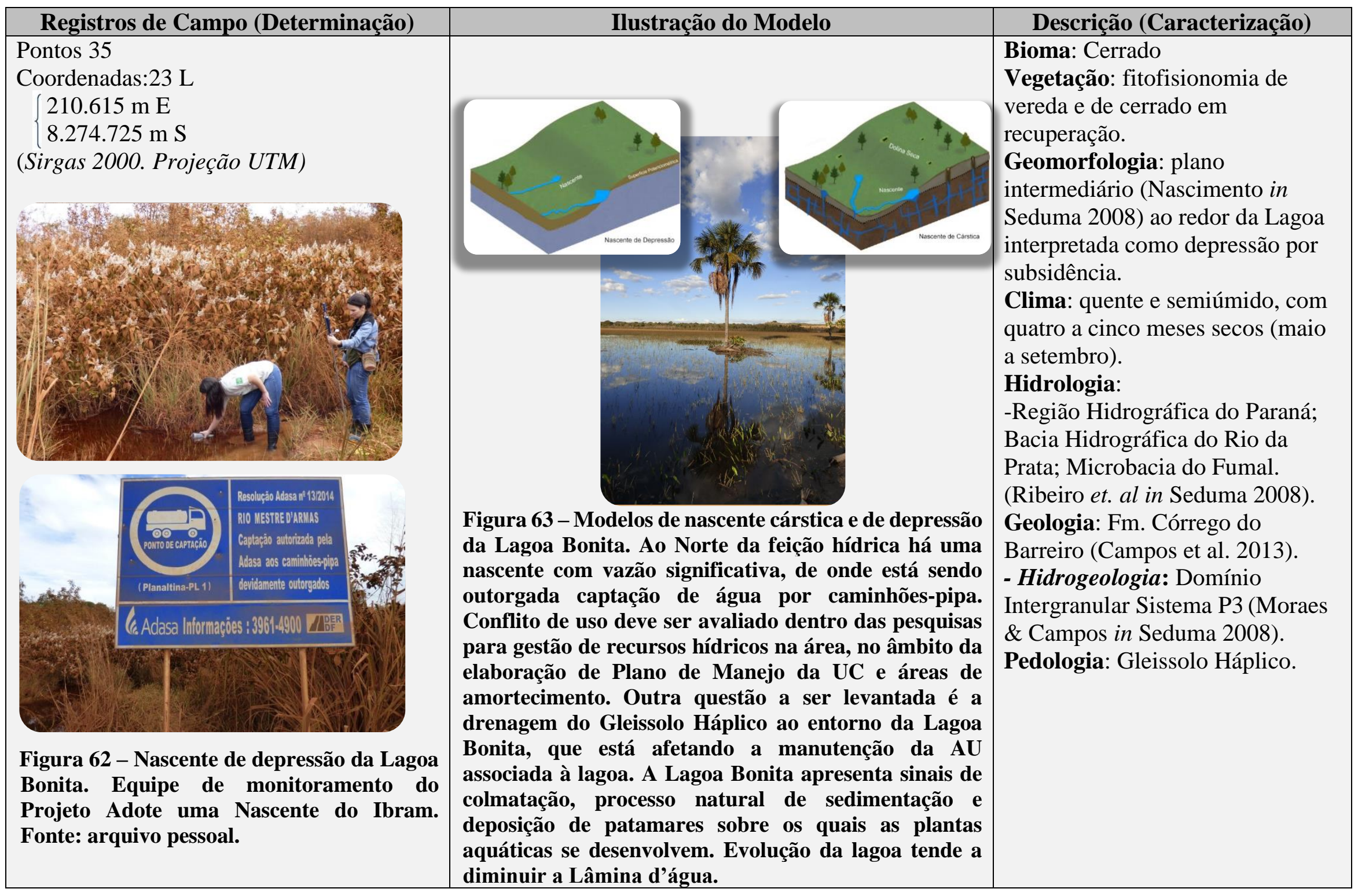




\section{CAPÍTULO 5 \\ CONSIDERAÇÕES FINAIS}

O conhecimento sobre nascentes, veredas e áreas úmidas em geral ainda apresenta lacunas do ponto de vista técnico, acadêmico e legal que justificam o desenvolvimento de estudos específicos e intrínsecos ao seu respeito. Os estudos devem favorecer a adoção de conceitos mais adequados a partir de metodologia de determinação e de caracterização das feições hídricas. Acredita-se que a aplicação desses conceitos e métodos de determinação e caracterização beneficie a adoção de medidas de conservação, de mitigação e de recuperação de corpos hídricos em território nacional, com base em princípios internacionalmente reconhecidos.

Diante das controvérsias acerca das feições de interface entre o sistema aquífero e sistema superficial, esta dissertação propõe revisão conceitual sob o ponto de vista técnico e legal de nascentes e áreas úmidas em geral - em especial as veredas. A linha de pesquisa enfatiza a proteção da qualidade da água subterrânea e superficial e dos sistemas ecológicos relacionados às feições hídricas, entre os quais os solos com elevado grau de hidromorfismo.

Em síntese, a proposta conceitual separa os conceitos de cabeceiras, nascentes, olhos d'água e fonte. Acredita-se que a precisão dos termos beneficia a elaboração de modelos técnicoscientíficos e, consequentemente, a aplicação de instrumentos de proteção adequados. Nascentes e cursos de água são vistos como integrantes da rede fluvial regular. No entanto, à cabeceiras e olhos d'água em geral se aplica a noção de áreas úmidas (AUs). De acordo com as funções ambientais que apresentam, podem ser classificados no Inventário Brasileiro de Áreas Úmidas (Inventário de Zonas Úmidas), que deve orientar a aplicação dos instrumentos de proteção dessas feições hídricas, especialmente por meio de zoneamento.

O mesmo ocorre com as veredas. A partir da visão integrada, veredas são consideradas como uma classe de AUs, cujo elevado grau de hidromorfismo é o critério identificador e a fitofisionomia, o critério tipificador. $\mathrm{O}$ sistema bem definido de instrumentos legais integrados será favorável à proteção de ambientes aquáticos e de ambientes transicionais, com suas funções interações ambientais garantidas.

A partir da revisão conceitual de nascentes, veredas e áreas úmidas, este trabalho propõe o desenvolvimento e a aplicação de método de determinação e de caracterização das feições para a adequada aplicação dos instrumentos de proteção:

- Primeira etapa - Determinação: obtenção de dados, por meio de levantamentos espaciais, temporais e de campo. Como produto da fase de determinação, elaboram-se os cenários espaçotemporais da área de estudo, com base em critérios identificadores das feições.

- Segunda etapa - Caracterização: descrição das feições quanto aos critérios tipificadores. Isto permite o desenvolvimento de modelos conceituais do contexto das feições hídricas, produtos da integração da primeira e segunda etapas. 
- Terceira etapa - Aplicação dos instrumentos de proteção: utilização dos modelos conceituais para a adequada aplicação dos instrumentos de proteção caso a caso.

O método proposto é aplicado no estudo de caso da Estação Ecológica de Águas Emendadas. Com base nos resultados, o trabalho agrega a aplicação dos conceitos de nascentes, veredas e áreas úmidas, a partir da adequada caracterização e determinação de feições, e traça sugestões de desmembramentos de questões para futuras análises na ESEC-AE.

\subsection{Sugestões de aperfeiçoamento da legislação brasileira quanto a nascentes, veredas} e áreas úmidas

$\mathrm{Na}$ aplicação prática balizada nos preceitos legais, a busca pela precisão dos termos é necessária à potencialização do exercício da justiça. Nesse caso, a aplicação de termos mesclados é um problema prático e não apenas um aspecto conceitual. As controvérsias conceituais de nascentes, veredas e áreas úmidas têm importantes implicações jurídicas. De acordo com a legislação brasileira, nascentes, veredas e áreas úmidas apresentam instrumentos jurídicos de preservação diferenciados, com garantias ambientais variáveis de acordo com cada definição de tipologia. Portanto, sugere-se a adoção dos conceitos propostos nesta dissertação na Lei 12.651/2012. Além disso, ressalta-se a necessidade de criação de legislação específica para Áreas Úmidas.

Na ocasião de fechamento desta dissertação, a apresentação das discussões e sugestões deste trabalho é oportuna. O Projeto de Lei 350/15, do deputado Sarney Filho (PV-MA), que altera o novo Código Florestal (Lei 12.651/12), está tramitando com o objetivo de proteger as nascentes intermitentes. Enquanto segue pelas comissões temáticas faz-se importante a participação popular e articulação da sociedade em prol do aperfeiçoamento da legislação. Em vista disto, esta dissertação tem o potencial de acrescentar elementos técnicos ao favorável momento de revisão das previsões da lei.

A autora desta dissertação compromete-se com a disponibilidade de envolvimento e de eventuais esclarecimentos para a implementação de conceitos mais adequados à proteção de nascentes, veredas e áreas úmidas e com a elaboração de publicações científicas com eventuais colaboradores interessados acerca do tema.

\section{Desdobramentos do estudo de caso}

Especificamente quanto ao estudo de caso, os objetivos do trabalho são escalonados e permitem desdobramentos em fases de futuros estudos técnicos e científicos:

1) A partir da proposição de reconhecimento de solos com elevado grau de hidromorfismo ${ }^{17}$ como critério identificador de áreas úmidas, reconhecer os Paleogleissolos como

\footnotetext{
${ }^{17}$ Tema de artigo apresentado como requisito para a obtenção do título de mestre.
} 
registros da dinâmica ambiental, caracteristicamente transicional.

2) Verificação da diminuição das áreas úmidas. Essa questão relevante vem sendo levantada pelo órgão ambiental do Distrito Federal, Ibram, e há indícios de transformação de paisagens. A análise baseia-se em três frentes: solos; vegetação; dados temporais/espaciais. A outra questão que surge a partir desta análise é relativa às possíveis fontes de diminuição dimensional das áreas úmidas da ESEC-AE. Hipóteses (integradas e cumulativas): processos naturais (mudanças climáticas e dinâmica de transformação de solos, regime hídrico e fitofisionomias); processos antrópicos (ocupação da área de recarga, captação, sistema de drenos e intervenções em vias de acesso).

3) Proposta de medidas de mitigação e recuperação de áreas úmidas na ESEC-AE. Este tópico depende dos resultados e do amadurecimento das ideias sobre os processos em curso e conclusões da fase anterior.

4) Proposta de reconhecimento da ESEC-AE como Sítio Ramsar. 


\section{REFERÊNCIAS}

Aguiar Netto, A.O.; Nacif, P.G.S; Rezende, J.O. Avaliação do conceito de capacidade de campo para um latossolo amarelo coeso do estado da Bahia. Revista Brasileira de Ciência do Solo, 23:661-667.

Agência Nacional de Águas. 2011. Outorga de direito de uso de recursos hídricos. Caderno de Capacitação em Recursos hídricos. Volume 6. Brasília: SAG. 50 p.

Andrade, M.M. 2010. Introdução à Metodologia do Trabalho Científico. São Paulo, Atlas, 158 p.

Araújo, G. M.; Barbosa, A.A.A; Arantes, A.A; Amaral, A.F. Composição florística de veredas no município de Uberlândia, MG. Revista Brasileira de Botânica. 2002. v. 25, n. 4, p. 475-493.

Arraes, T.M. 2008. Proposição de critérios e métodos para delimitação de bacias hidrogeológicas. Dissertação de Mestrado. Instituto de Geociências, Universidade de Brasília, Brasília, 108 p.

Associação Brasileira de Normas Técnicas. NBR-10520: Informação e Documentação Apresentação de citações em documentos. Rio de Janeiro, 2002a, 4 p.

Associação Brasileira de Normas Técnicas. NBR-14724: Informação e Documentação - Trabalhos Acadêmicos - Apresentação. Rio de Janeiro, 2002b. 6 p.

Associação Brasileira de Normas Técnicas. NBR-6023: Informação e Documentação Referências - Elaboração. Rio de Janeiro, 2002c. 22 p.

Associação Brasileira de Normas Técnicas. NBR-6024: Numeração Progressiva das seções de um documento - Procedimento. Rio de Janeiro, 2003.

Baptista, G.M.M. 2008. Modelagem do fenômeno. In: Seduma. Águas Emendadas. Fonseca, F.O. (org). -Brasília: Seduma, 542 p.

Barberi, M.; Salgado-Labouriau, M.L.; Suguio, K. 2000. Paleovegetation and paleoclimate of "Vereda de Águas Emendadas", DF, Central Brazil. Journal South American Earth Sciences, 13: 241-254, DOI: 10.1016/S0895-9811.

Barberi, M. 2008. História Ecológica. In: Seduma. 2008. Águas Emendadas. Fonseca, F.O. (org). -Brasília: Seduma, 542 p.

Booth, W.C.; Colomb, G.G.; Williams, J.M. 2008. A arte da pesquisa. São Paulo, Martins Fontes, $351 \mathrm{p}$.

Bouma, J.; Fox, C.A.; Miedema, R. 1990. Micromorphology of hydromorphic soils: Applications for soil genesis and land evaluation. Developments in Soil Science 19:157-278.

Bove, C.P.; Gil, A.S.B.; Moreira, C.B.; Anjos, R.F.B. 2003. Hidrófitas fanerogâmicas de ecossistemas aquáticos temporários da planície costeira do estado do Rio de Janeiro, Brasil. Acta Bot. Bras., v. 17, n. 1, p. 119-135. Disponível em: < http://www.scielo.br/pdf/pd/v29n1/a02v29n1>. Acesso em: 15 nov 2015.

Borges, B.C.; Baptista, G.M.M.; Meneses, P.R. 2014. Identificação de Áreas Hidromórficas, por Meio de Análise Espectral de Dados de Sensoriamento Remoto, como Subsídio para a Elaboração de Laudos Periciais de Avaliação de Imóveis Rurais. Revista Brasileira de Geografia Física, vol.7, no 6 1062-1077. Disponível em: < http://www.revista.ufpe.br/ rbgfe/index.php/revista/article/view/750/694>. Acesso em: 24 nov. 2015.

Brandão, M.; Carvalho, P. G.S.; Baruqui, F. M. Veredas: uma abordagem integrada. Daphne. 1991. v. 1, n. 3, p. 5-8.

Brasil. 1945. Decreto-Lei 7.841, de 8 de agosto de 1945. Código de Águas Minerais. Diário Oficial da República Federativa do Brasil. Brasília, 20 ago 1945. Disponível em: <http://www.planalto.gov.br/ccivil_03/decreto-lei/1937-1946/Del7841.htm>. Acesso em: 15 nov. 2015.

Brasil. 1965. Código Florestal - Lei 4.771, de 15 de setembro de 1965, revogada pela Lei 12.651, de 25 de maio de 2012. Disponível em: <http://www.planalto.gov.br/ccivil_03/Leis/ L4771.htm>. Acesso em 28 jan. 2016.

Brasil. 1981. Lei 6.938, de 31 de agosto de 1981. Dispõe sobre a Política Nacional do Meio Ambiente, seus fins e mecanismos de formulação e aplicação, e dá outras providências. Diário Oficial da República Federativa do Brasil. Brasília, 31 ago 1981. Disponível em: 
<http://www.planalto.gov.br/ccivil_03/Leis/L6938.htm>. Acesso em: 29 out. 2015.

Brasil. 1988. a. Constituição da República Federativa do Brasil, de 5 de outubro de 1988. Diário Oficial da União. Disponível em: <http://www.planalto.gov.br/ccivil_03/Constituicao/ConstituicaoCompilado.htm>.

Brasil. 1988. b. Lei 7.661, de 16 de maio de 1988. Institui o Plano Nacional de Gerenciamento Costeiro e dá outras providências. Diário Oficial da República Federativa do Brasil. Brasília, 16 maio 1988. Disponível em: <http://www.planalto.gov.br/ccivil_03/Leis/L7661.htm>. Acesso em: 3 out 2014.

Brasil. 1996. Decreto 1905, de 16 de maio de 1996. Promulga a Convenção sobre Zonas Úmidas de Importância Internacional, especialmente como Habitat de Aves Aquáticas, conhecida como Convenção de Ramsar, de 02 de fevereiro de 1971. Diário Oficial da República Federativa do Brasil. Brasília, 16 maio 1996. Disponível em: < http://www.planalto.gov.br/ccivil_03/decreto/1996/D1905.htm>. Acesso em: 29 out. 2015.

Brasil. 1997. Lei 9.433, de 8 de janeiro de 1997. Institui a Política Nacional de Recursos Hídricos, cria o Sistema Nacional de Gerenciamento de Recursos Hídricos, regulamenta o inciso XIX do art. 21 da Constituição Federal, e altera o art. $1^{\circ}$ da Lei n $^{\circ} 8.001$, de 13 de março de 1990, que modificou a Lei $\mathrm{n}^{\circ} 7.990$, de 28 de dezembro de 1989. Diário Oficial da República Federativa do Brasil. Brasília, 9 jan 1997. Disponível em: < http://www.planalto.gov.br/ccivil_03/LEIS/L9433.htm>. Acesso em: 29 out. 2015.

Brasil, 2000. Lei 9.985, de 18 de julho de 2000. Regulamenta o art. 225, $\S 1^{\circ}$, incisos I, II, III e VII da Constituição Federal, institui o Sistema Nacional de Unidades de Conservação das Natureza e dá outras providências. Diário Oficial da República Federativa do Brasil. Brasília, 18 jul 2000. Disponível em: <www.planalto.gov.br/ccivil_03/LEIS/L9985.htm>. Acesso em: 25 jan 2016.

Brasil. 2002. Decreto 4.339, de 22 de agosto de 2002. Institui princípios e diretrizes para a implementação da Política Nacional da Biodiversidade. Diário Oficial da República Federativa do Brasil. Brasília, 23 ago. 2002. Disponível em: < http://www.planalto.gov.br/ccivil_03/decreto/2002/d4339.htm>. Acesso em: 3 out 2014.

Brasil. 2002. Resolução no 303, de 20 de março de 1992. Dispõe sobre parâmetros, definições e limites de Áreas de Preservação Permanente. Conselho Nacional do Meio Ambiente. Disponível em: < http://www.mma.gov.br/port/conama/res/res02/res30302.html>. Acesso em: 5 out 2014.

Brasil. 2005. Resolução no 357 , de 17 de março de 2005. Dispõe sobre a classificação dos corpos de água e diretrizes ambientais para o seu enquadramento, bem como estabelece as condições e padrões de lançamento de efluentes, e dá outras providências. Conselho Nacional do Meio Ambiente. Disponível em: <www.mma.gov.br/port/conama/res/res05/res35705.pdf>. Acesso em: 15 maio 2014.

Brasil. 2008. Resolução n ${ }^{\circ} 396$, de 7 de abril de 2008. Dispõe sobre a classificação e diretrizes ambientais para o enquadramento das águas subterrâneas e dá outras providências. Conselho Nacional do Meio Ambiente. Disponível em: < http://www.mma.gov.br/port/conama/legislacao/CONAMA_RES_CONS_2008_396.pdf>. Acesso em: 15 novembro 2015.

Brasil. 2009. Resolução Conama $n^{\circ} 420$, de 28 de dezembro de 2009. Dispõe sobre critérios e valores orientadores de qualidade do solo quanto à presença de substâncias químicas e estabelece diretrizes para o gerenciamento ambiental de áreas contaminadas por essas sustâncias em decorrência de atividades antrópicas. Conselho Nacional do Meio Ambiente. Disponível em: <www.mma.gov.br/port/conama/lwgiabre. cfm?codlegi=620. Acesso em: 15 maio 2014.

Brasil. 2011. Portaria n ${ }^{\circ}$ 2.914, de 12 de dezembro de 2011 Brasil. 2004. Brasil. 2004. Portaria $\mathrm{n}^{\circ}$ 518 , de 25 de março de 2004. Dispõe sobre os procedimentos de controle e de vigilância da qualidade da água para consumo humano e seu padrão de potabilidade. Ministério da Saúde. Disponível em: < http://bvsms.saude.gov.br/bvs/saudelegis/gm/2011/prt2914_12_12_ 2011.html>. Acesso em: 17 jan 2016. 
Brasil. 2012. a. Lei $n^{o} 12.651$, de 25 de Maio de 2012. Dispõe sobre a proteção da vegetação nativa; altera as Leis nos 6.938, de 31 de agosto de 1981, 9.393, de 19 de dezembro de 1996, e 11.428, de 22 de dezembro de 2006; revoga as Leis nos 4.771, de 15 de setembro de 1965, e 7.754, de 14 de abril de 1989, e a Medida Provisória no 2.166-67, de 24 de agosto de 2001; e dá outras providências. Diário Oficial da República Federativa do Brasil. Brasília, 28 maio 2012. Disponível em: <http://www.planalto.gov.br/ccivil_03/_Ato20112014/2012/Lei/L12651.htm>. Acesso em: 3 out 2014.

Brasil. 2012. b. Lei $n^{\circ}$ 12.727, de 17 de Outubro de 2012. Altera a Lei n 12.651, de 25 de maio de 2012, que dispõe sobre a proteção da vegetação nativa; altera as Leis $n^{\text {os }} 6.938$, de 31 de agosto de 1981, 9.393, de 19 de dezembro de 1996, e 11.428, de 22 de dezembro de 2006; e revoga as Leis $\mathrm{n}^{\text {os }} 4.771$, de 15 de setembro de 1965 , e 7.754 , de 14 de abril de 1989, a Medida Provisória n 2.166-67, de 24 de agosto de 2001, o item 22 do inciso II do art. 167 da Lei n 6.015, de 31 de dezembro de 1973, e o $\$ 2$ do art. 4o da Lei n 12.651, de 25 de maio de 2012. Diário Oficial da República Federativa do Brasil. Brasília, 17 outubro. 2012. Disponível em: <http://www.planalto.gov.br/ccivil_03/_ato2011-2014/2012/lei/ L12727.htm>. Acesso em: 3 out. 2014.

Brasil. 2012. c. Decreto 7.830, de 17 de outubro de 2012. Dispõe sobre o Sistema de Cadastro Ambiental Rural, o Cadastro Ambiental Rural, estabelece normas de caráter geral aos Programas de Regularização Ambiental, de que trata a Lei no 12.651, de 25 de maio de 2012, e dá outras providências. Diário Oficial da República Federativa do Brasil. Brasília, 18 outubro. 2012. Disponível em: <http://www.planalto.gov.br/ccivil_03/_Ato20112014/2012/Decreto/ D7830.htm. Acesso em: 9 nov. 2015.

Brazilian Journal of Geology. Diretrizes para autores. Disponível em: http://rbg.sbgeo.org.br/index.php/rbg/about/submissions\#authorGuidelines. Acesso em: 2 nov. 2014.

Brouwer, J. \& Fitzpatrick, R. W. 2002. Restricting layers, flow paths and correlation between duration of soil saturation and soil morphological features along a hillslope with an altered soil water regime in western Victoria. Australian Journal of Soil Research 40(6):927-946.

Campos, A.B.; Cedro, D.A.B; Tejerina-Garro, F.L; Bayer, M.; Carneiro, G.T. 2013. Spatial distribution of tropical wetlands in Central Brazil as influenced by geological and geomorphological settings. Journal of South American Earth Sciences 46 (2013) 161-169.

Campos, J.E.G. \& Dardenne, M.A. 1999. Distribuição, estratigrafia e sistemas deposicionais do Grupo Urucuia - Cretáceo Superior da Bacia Sanfranciscana. Geociências (Impresso) 18(2): 481-499.

Campos, J.E.G. Dimensão da Singularidade. In: Seduma. 2008. Águas Emendadas. Fonseca, F.O. (org). -Brasília: Seduma, 542 p.

Campos, J.E.G.; Dardenne, M.A.; Freitas-Silva, F. H.; Martins-Ferreira, M.A.C. 2013. Geologia do Grupo Paranoá na porção externa da Faixa Brasília. Brazilian Journal of Geology, 43:461476.

Campos, J.E.G.; Freitas-Silva, F.H. Hidrogeologia do Distrito Federal. In: IEMA/SEMATEC/UnB. Inventário hidrogeológico e dos recursos hídricos superficiais do Distrito Federal. Brasília. 1998. v. 4, 85 p.

Carvalho, R.D. Localização da Unidade. In: SEDUMA 2008. . Águas Emendadas. Fonseca, F.O. (org). -Brasília: Seduma, 542 p.

Coringa, E.A.O.; Couto, E.G.; Perez, X.L.O.; Torrado, P.V. 2012. Atributos de solos hidromórficos no Pantanal Norte Mato-grossense. Acta Amazônica 42(1): 19-28.

Costa, A.F. Zonação no gradiente vegetacional cerrado típico - campo sujo - vereda, na estação ecológica de águas emendadas, Brasília - DF. 2007. Dissertação de Mestrado. Instituto de Ciências Biológicas, Departamento de Ecologia, Universidade de Brasília, Brasília, 76 p.

Cunha, C.N.; Piedade, M.T.F.; Junk, W.F. 2015. Classificação e Delineamento das Áreas Úmidas Brasileiras e de seus Macrohabitats. Instituto Nacional de Ciência e Tecnologia em Áreas Úmidas - INAU. Cuiabá, 2015. EdUFMT. Disponível em: <www.INAU.org.br/imprensa/?CategoriaCod=1>. Acesso em: 6 out 2015. 
Dias, B. F. S. A Conservação da Natureza no Cerrado Brasileiro. In: PINTO, M. N. (org.). Cerrado: caracterização, ocupação e perspectivas. 2. ed. Brasília: Editora da Universidade de Brasília, SEMATEC. 1993. p. 607-663.

Distrito Federal. 1968. Decreto N. ${ }^{\circ} 771$, de 12 de agosto de 1968. Cria a Reserva Ecológica de "Águas Emendadas", e dá outras providências. Diário Oficial da União. Brasília, 3 de jul. de 1981. Disponível em: <http://www.recursoshidricos.df.gov.br/aguas_emendadas/ legislacaoDecreto_771.pdf >. Acesso em: 17 nov. 2015.

Distrito Federal. 1988. Decreto 11.137, de 16 de junho de 1988. Modifica a denominação da Reserva Biológica de Águas Emendadas, e dá outras providências. Diário Oficial do Distrito Federal. Brasília, 16 de junho de 1988. Disponível em: < http://www.recursoshidricos.df.gov.br/aguas_emendadas/legislacao/Decreto_11137.pdf>. Acesso em: 17 nov. 2015.

Distrito Federal. 1993. Decreto $\mathrm{n}^{\mathrm{o}}$ 14.662, de 02 de abril de 1993. Altera o art. $3^{\circ}$ do Decreto 771/1968, que cria a Reserva Biológica de Águas Emendadas. Disponível em: <http://www.recursoshidricos.df.gov.br/aguas_emendadas/legislacaoDecreto_771.pdf>.

Acesso em: 17 nov. 2015.

Distrito Federal. 2012. Lei complementar $\mathrm{n}^{\circ}$ 854, de 15 de outubro de 2012. Atualiza a Lei Complementar $\mathrm{n}^{\circ}$ 803, de 25 de abril de 2009, que aprova a revisão do Plano Diretor de Ordenamento Territorial do Distrito Federal - PDOT e dá outras providências. Diário Oficial do Distrito Federal. Brasília, 17 de outubro de 2012. Disponível em: < http://www.sedhab.df.gov.br/preservacao-e-planejamento-urbano/pdot.html>. Acesso em: 17 nov. 2015.

Distrito Federal. 2014. Instrução Normativa Ibram nº 39, de 21 de fevereiro de 2014. Dispõe sobre a preservação dos campos de murundus, também conhecidos como covais e dá outras providências. Diário Oficial do Distrito Federal. Brasília, 25 de fevereiro de 2014. Disponível em: <https://www.legisweb.com.br/legislacao/?id=265958>. Acesso em: 16 nov. 2015.

EITEN, G. Classificação da vegetação do Brasil. Brasília, DF: Conselho Nacional de Desenvolvimento Científico e Tecnológico - CNPq, 1983. 305 adas. Fonseca, F.O. (org). Brasília: Seduma, 542 p.

Eiten, G. 1972. Formas fisionômicas do Cerrado. Revista Brasileira de Botânica 2:139-148. 1979.

Eiten, G. The Cerrado vegetation of Brazil. Botanical Review 38: 201-341.

Eiten, G. 2001. Vegetação natural do Distrito Federal. Brasilia. UnB: SEBRAE, 162 p.

Eiten, G. Vegetação. In: NOVAES PINTO, M. (org.). Cerrado: caracterização, ocupação e perspectivas. 2. ed. Brasília: Editora da Universidade de Brasília, SEMATEC.1993. p. 1773.

Embrapa. 1978. Levantamento de reconhecimento dos solos no Distrito Federal. Serviço Nacional de Levantamento e Conservação dos Solos. Rio de Janeiro, 1978. 455 p.

Embrapa. 2013. Sistema Brasileiro de Classificação de Solos. Centro Nacional de Pesquisa de Solos. Rio de Janeiro, Embrapa Solos, 353p.

Estados Unidos. 1975. Soil taxonomy: a basic system of soil classification for making and interpreting soil surveys. In: Embrapa. 2013. Sistema Brasileiro de Classificação de Solos. Centro Nacional de Pesquisa de Solos. Rio de Janeiro, Embrapa Solos, 353p.

Faegri, K.; Iversen, J. Textbook of Modern Pollen Analysis. Copenhagen: Munksgaard, 1950. In:

Barberi, M. 2008. História Ecológica. In: Seduma. Águas Emendadas. Fonseca, F.O. (org). Brasília: Seduma, $542 \mathrm{p}$.

Felfili, J.M.; Ribeiro, J.F.; Fagg. C.W.; Machado, J.W.B. 2000. Cerrado: Manual de Recuperação de Matas de Galeria. Planaltina, Embrapa Cerrados, 45 p. Disponível em: <www.cpac.embrapa.br/download/1360/t>. Acesso em: 3 set 2015.

Felfili, J. M; Silva Júnior, M.C; Mendonça, R.C; Fagg, C.W.; Filgueiras, T.S; Mecenas, V.V. Fitofisionomias e flora. In: Seduma. Águas Emendadas. Fonseca, F.O. (org). -Brasília: Seduma, $542 \mathrm{p}$.

Ferreira, M. B. 1980. O cerrado em Minas Gerais: gradações e composição florística. In: Munhoz, 
C.B.R.; Ribeiro, J.F. 2008. Veredas. In: Seduma. Águas Emendadas. Fonseca, F.O. (org). Brasília: Seduma, 542 p.

Ferreira, A.B.H. 2010. Dicionário Aurélio da Língua Portuguesa. Curitiba, Positivo, 2222 p.

Ferreira, T.O. Processos pedogenéticos e biogeoquímica de Fe e S em solos de manguezais. 2005. Tese (Doutorado em Solos e Nutrição de Plantas) - Escola Superior de Agricultura Luiz de Queiroz, Universidade de São Paulo, Piracicaba, 2006. Disponível em: $<$ http://www.teses.usp.br/teses/disponiveis/11/11140/tde-05042006-162745/> Acesso em: 28 ago 2015.

Fetter, C. W. 2001. Applied hydrogeology. Upper Saddle River, N.J: Prentice Hall, 598 p.

Fiori, J.P.O.; Campos, J.E.G.; Almeida, L. 2010. Variabilidade da condutividade hidráulica das principais classes de solos do estado de Goiás. Geociências (Impresso), 29:229-235.

Freitas-Silva, F.H.; Campos, J.E.G. Geologia do Distrito Federal. In: IEMA/SEMATEC/UnB. Inventário hidrogeológico e dos recursos hídricos superficiais do Distrito Federal. Brasília. 1998. v. $1=1-86 \mathrm{p}$

Gill, W.R. \& Sherman G.D. 1992. Properties of the Gray Hydromorphic Soils of the Hawaiian Islands. $165 \mathrm{p}$.

Guerra, A. T; Guerra, A.J.T. 2009. Novo Dicionário Geológico-Geomorfológico. Rio de Janeiro, Bertrand Brasil, 648 p.

Hack, J. T \& Goodlett, J. C. 1960. Geomorphology and forest ecology of mountain region in the central Appalachians: In: Guerra, A. T; Guerra, A.J.T. 2009. Novo Dicionário GeológicoGeomorfológico. Rio de Janeiro, Bertrand Brasil, p. 97.

Hewlett, J.D. 1982 Principles of Forest Hydrology. In: Baptista, G.M.M. 2008. Modelagem do fenômeno. In: Seduma. Águas Emendadas. Fonseca, F.O. (org). -Brasília: Seduma, 542 p.

Horowitz, C.; Jesus, F. Áreas Naturais Protegidas. In: Seduma. Águas Emendadas. Fonseca, F.O. (org). -Brasília: Seduma, 542 p.

Houaiss, A.; Villar, M.S. 2009. Dicionário Houaiss da Língua Portuguesa. Rio de janeiro, Objetiva, 1986 p.

Hussain, M.S. \& Swindale, L.D. 1970. A Morphological and Mineralogical Study of the Gray Hydromorphic Soils of the Hawaiian Islands. Pacific Science 24:543-553.

Instituto Brasileiro de Geografia e Estatística - IBGE. a. Diretoria de Geociências Coordenação de Recursos Naturais e Estudos Ambientais. Vocabulário Básico de Recursos Naturais e Meio ambiente. Rio de Janeiro, 2004. Disponível em: <http://www.ibge.gov.br/home/geociencias/recursosnaturais/sistematizacao/recursos_natur ais_bvocabulario.shtm>. Acesso em: 27 out. 2014.

Instituto Brasileiro de Geografia e Estatística - IBGE. b. Diretoria de Geociências Coordenação de Recursos Naturais e Estudos Ambientais. Manuais Técnicos em Geociências, número 4: Manual Técnico de Pedologia. Rio de Janeiro, 2007. Disponível em: http://www.ibge.gov.br/home/geociencias/recursosnaturais/sistematizacao/ manual_pedologia.shtm. Acesso em: 27 out. 2014.

Instituto Brasileiro de Geografia e Estatística - IBGE. c. Diretoria de Geociências Coordenação de Recursos Naturais e Estudos Ambientais. Manuais Técnicos em Geociências, número 5: Manual Técnico de Geomorfologia. Rio de Janeiro, 2009. Disponível em: http://www.ibge.gov.br/home/geociencias/recursosnaturais/sistematizacao /manual_geomorfologia.shtm. Acesso em: 27 out. 2014.

Iriondo, M. 2004. Large wetlands of South America: a model for Quaternary humid environments. Quaternary International 114: 3-9. Disponível em: <http://www.sciencedirect.com/science/article/pii/S1040618203000375>. Acesso em: 22 nov. 2015.

Junk, W.J.; Piedade, M.T.F.; Schöngart, J.; Cohn-Haft, M.; Adeney J.M.; Wittmann, F. 2011. A classification of major naturally-occurring Amazonian lowland wetlands. Disponível em: $<$ http://www.scielo.br/scielo.php?script=sci_nlinks\&pid=S1519-698420140004008100004 4\&lng=en>. Acesso em 22 nov. 2015.

Junk, W.J.; Bayley, P.B.; Sparks, R.E. (1989). The Flood Pulse Concept in River-Floodplain- 
Systems. Canadian Special Publications for Fisheries and Aquatic Sciences. In: Cunha, C.N.; Piedade, M.T.F.; Junk, W.F. 2015. Classificação e Delineamento das Áreas Úmidas Brasileiras e de seus Macrohabitats. Instituto Nacional de Ciência e Tecnologia em Áreas Úmidas - INAU. Cuiabá, 2015. EdUFMT. Disponível em: <www.INAU.org.br/imprensa/?CategoriaCod=1>. Acesso em: 6 out 2015.

Lacerda, M.P.C. 2008. Solos. In: Seduma. Águas Emendadas. Fonseca, F.O. (org). -Brasília: Seduma, $542 \mathrm{p}$.

Leinz, V. 1982. Glossário Geológico: com a correspondente terminologia em inglês, alemão e francês. São Paulo, Companhia Editora Nacional, 236 p.

Libault, A. Geocartografia. São Paulo. São Paulo: Edusp. São Paulo: Ed. Nacional, 1975.

Lima, E.J. 2011. Composição e distribuição de comunidades de plantas aquáticas em duas lagoas no pantanal goiano, Flores de Goiás, Brasil. Dissertação de Mestrado. Faculdade de Tecnologia, Departamento de Engenharia Florestal, Universidade de Brasília, Brasília, 76. p.

J.E.F.W; Silva, E.M. 2008. Hidrografia. In: Seduma. Águas Emendadas. Fonseca, F.O. (org). Brasília: Seduma, $542 \mathrm{p}$.

Magalhães (1966) apud Munhoz e Ribeiro in Seduma 2008. In: Seduma. Águas Emendadas. Fonseca, F.O. (org). -Brasília: Seduma, 542 p.

Marconi, M.A. \& Lakatos, E.M. 2010. Fundamentos de Metodologia Científica. São Paulo, Atlas, $297 \mathrm{p}$.

Mello, T.R.B. 2012. Comunidades herbáceo-arbustivas e suas relações com solo e altitude, em áreas secas e úmidas, no parque nacional das sempre vivas, MG. Ph.D. Dissertação de Mestrado, Instituto De Ciências Biológicas, Universidade De Brasília, Brasília, 58 P.

Melo, D. R. 1992. As veredas nos planaltos do noroeste mineiro: caracterizações pedológicas e os aspectos morfológicos e evolutivos. In: Munhoz, C.B.R; Ribeiro, J.F. 2008. In: Seduma. Águas Emendadas. Fonseca, F.O. (org). -Brasília: Seduma, 542 p.

Moraes, L.L; Campos, J.E.G. 2008. Geologia. In: Seduma. Águas Emendadas. Fonseca, F.O. (org). -Brasília: Seduma, 542 p.

Moraes, L.L; Campos, J.E.G. 2008. Hidrogeologia. In: Seduma. Águas Emendadas. Fonseca, F.O. (org). -Brasília: Seduma, 542 p.

Moran, E.F. 2011. Meio Ambiente e Ciências Sociais. São Paulo, Senac, 307 p.

Munhoz, C.B.R; Ribeiro, J.F. 2008. In: Seduma. Águas Emendadas. Fonseca, F.O. (org). Brasília: Seduma, 542 p.

Nascimento, R.O. 2008. Geomorfologia. In: Fonseca, F.O (org.). Águas Emendadas/Distrito Federal. Secretaria de Desenvolvimento Urbano e Meio Ambiente. Brasília: Seduma. 542 p.

Pérez-Garcia, C.F.; Lima, H.N.; Silva, F.W.R. Neves, A.F.; Teixeira, W.G. Macêdo, R.S.; Tavares, S.G. 2013. Chemical properties and mineralogy of soils with plinthite and petroplinthite in Iranduba (AM), Brazil. Revista Brasileira de Ciências o Solo 37:936-946.

Pio, B.L.A. 2010. Comparação da distribuição geográfica potencial de Buriti, Mauritia flexuosa L. (araceae) gerada por diferentes modelos preditivos. Dissertação de Mestrado. Instituto de Ciências Biológicas, Universidade de Brasília, Brasília, 83 p.

Pott, V.J.; Pott, A. 2000. Plantas aquáticas do Pantanal. Brasília: Embrapa, 404 p.

Queiroz, M.L. 2014. Valores orientadores aplicados à avaliação pericial de alterações na qualidade da água - Estudo de caso no parque olhos d'água quanto a compostos nitrogenados. BrasíliaDF.. Monografia de Especialização em Perícia e Auditoria Ambiental. Faculdade Estácio de Sá. São Paulo, 39 p.

Ribeiro, J.F.; Walter, B.M.T. 1998. Fitofisionomias do Bioma Cerrado. In: Sano, S.M.; Almeida, S.P., ed. Cerrado: ambiente e flora. Planaltina, Embrapa-CPAC, p. 89-152. Disponível em: < www.cpac.embrapa.br/download/475/t>. Acesso em: 3 set 2015.

Ribeiro, J.F.; Walter, B.M.T; Fonseca, C.E.L. da. 1999. Ecossistemas de Matas Ciliares. In: Simpósio Matas Ciliares: Ciência E Tecnologia. Belo Horizonte, MG. Anais: Belo Horizonte: CEMIG/UFLA, p. 12-25.

Ribeiro, M.C.L.B; Perdigão, V.S.J; Rosa, J.W.C; Rosa, J.W.C; Santos; M.V. Uma explicação 
biogeográfica. In: . In: Seduma. Águas Emendadas. Fonseca, F.O. (org). -Brasília: Seduma, $542 \mathrm{p}$.

Rushton, K.R. 2006. Groundwater Hydrology: Conceptual and Computacional Models. Inglaterra, Wiley, 416 p.b

Salgado-Labouriau M. L.; Barberi, M.; Ferraz-Vicentini, K.R.; Parizzi, M.G. A dry climatic event during the late Quaternary. In: Barberi, M. 2008. História Ecológica. In: Seduma. 2008. Águas Emendadas. Fonseca, F.O. (org). -Brasília: Seduma, 542 p.

Santos, R.F. 2004. Planejamento Ambiental: teoria e prática. São Paulo: Oficina de textos.

São Paulo, 2010. Decreto $n^{\circ}$ 55.947, de 24 de junho de 2010. Regulamenta a Lei $n^{\circ} 13.798$, de 9 de novembro de 2009, que dispõe sobre a Política Estadual de Mudanças Climáticas. Diário Oficial do Estado de São Paulo. São Paulo, 25 jun. 2010. Disponível em: < http://www.legislacao.sp.gov.br/legislacao/dg280202.nsf/fc66ffd741d5df9683256c210061 079c/0ffa3c89c48c12690325774d0048ea14?OpenDocument>. Acesso em: 27 ago 2015.

São Paulo, 2010. Lei no 13.798, de 9 de novembro de 2009. Dispõe sobre a Política Estadual de Mudanças Climáticas. Assessoria Técnico-Legislativa. São Paulo, 9 nov. 2009. Disponível em: <http://www.al.sp.gov.br/repositorio/legislacao/lei/2009/lei-13798-09.11.2009.html>. Acesso em: 27 ago 2015.

São Paulo. 2009. Lei 13.577, de 8 de julho de 2009. Dispõe sobre diretrizes e procedimentos para a proteção da qualidade do solo e gerenciamento de áreas contaminadas, e dá outras providências correlatas. Disponível em: <www.al.sp.gov.br/repositorio/legislacao/lei/2009/lei-13577-08.07.2009.html>. Acesso em: 15 maio 2014.

Sarcinelli, T.S. 2010. Muçunungas: Enclaves de vegetação arenícola na Floresta Atlântica de Tabuleiro. Tese de doutorado. Programa de Pós-graduação em solos e nutrição de plantas. Universidade Federal de Viçosa, Viçosa, 186 p.

Secretaria de Desenvolvimento Urbano e Meio Ambiente - SEDUMA. 2008. Águas Emendadas. Fonseca, F.O. (org). -Brasília: Seduma, 542 p.

Severino, A.J. 2011. Metodologia do Trabalho Científico. São Paulo, Cortez, 304 p.

SCHENKEL, C. 2008. O conceito de reservas da biosfera. In: Seduma. 2008. Águas Emendadas.

Fonseca, F.O. (org). -Brasília: Seduma, 542 p.

Silva Filho, V.C. Área de influência nos estudos de impacto ambiental: uma heurística a partir da Geografia. Monografia de Especialização em Licenciamento Ambiental. Faculdades Integradas da Grande Fortaleza, Brasília 112 p.

Sotchava, V.B. 1978. Introdução à doutrina sobre os geossistemas. Editorial Nauka, Filial de Siberia, Novosibirsk, 1978, $318 \mathrm{p}$.

Somavilla, N.S. 2011. Aspectos anatômicos, fenológicos e ecofisiológicos de Melastomataceae em vereda e cerrado sensu stricto. Tese de Doutorado. Instituto de Ciências Biológicas, Departamento de Botânica, Universidade de Brasília, Brasília, 139 p.

Souza, C.R.G.; Hiruma, S.T.; Sallun, A.E.M; Ribeiro, R.R; Azevedo Sobrinho, J.M. 2008. "Restinga": Conceitos e Empregos do Termo no Brasil e Implicações na Legislação Ambiental. São Paulo, Instituto Geológico, 104p.

Souza, M. T.; Campos, J. E. G. O papel dos regolitos nos processos de recarga de aquíferos do Distrito Federal. Rev. Escola de Minas, Ouro Preto, 54. 2001.

Steinke, V.A. 2007. Identificação de Áreas Úmidas Prioritárias para conservação da biodiversidade na Bacia da Lagoa Mirim - Brasil-Uruguai: subsídios para gestão transfronteriça. Tese de Doutorado. Instituto de Ciências Biológicas, Departamento de Ecologia, Universidade de Brasília, Brasília 126 p.

Tiner, R.W. 1999. A guide to wetland identification, delineation, classification, and mapping. Estados Unidos, CRC Press, 424 p.

Valente, C.R.; Latrubesse, E.M.; Ferreira, L.G.2013. Relationships among vegetation, geomorphology and hydrology in the Bananal Island tropical wetlands, Araguaia River basin, Central Brazil. Journal of South American Earth Sciences, 30: 1-11, DOI: 10.1016/j.jsames.2012.12.003. 
Vieira, L.S. 1988. Manual de Ciência do solo com ênfase aos solos tropicais. Editora Agronômica Ceres LTDA. São Paulo. 464p.

Walter, B.M.T. 2006. Fitofisionomias do Bioma Cerrado: síntese terminológica e relações florísticas. Tese de Doutorado. Instituto de Ciências Biológicas, Departamento de Ecologia, Universidade de Brasília, Brasília, 373 p.

Warming, E. 1973. Lagoa Santa, contribuição para a geographia phytobiologica. In: Munhoz, C.B.R; Ribeiro, J.F. 2008. In: Seduma. Águas Emendadas. Fonseca, F.O. (org). -Brasília: Seduma, $542 \mathrm{p}$. 